(2) norden 



\section{De nye forbrugerkøbsregler i praksis}




\section{De nye forbrugerkøbsregler i praksis}

TemaNord 2006:533

(C) Nordisk Ministerråd, København 2006

ISBN 92-893-1334-X

Tryk: Ekspressen Tryk \& Kopicenter

Oplag: 250

Trykt på miljøvenligt papir som opfylder kravene i den nordiske miljøsvanemærkeordning.

Publikationen kan bestilles på www.norden.org/order. Flere publikationer på

www.norden.org/publikationer

Printed in Denmark

Nordisk Ministerråd

Store Strandstræde 18

1255 København K

Telefon (+45) 33960200

Fax (+45) 33960202

www.norden.org

\section{Nordisk Råd}

Store Strandstræde 18

1255 København K

Telefon (+45) 33960400

Fax (+45) 33111870

\section{Det nordiske samarbejde}

Det nordiske samarbejde er et af de ældste og mest omfattende regionale samarbejder i verden. Det omfatter Danmark, Finland, Island, Norge og Sverige samt Færøerne, Grønland og Åland. Samarbejdet styrker samhørigheden mellem de nordiske lande med respekt for de nationale forskelle og ligheder. Det øger mulighederne for at hævde Nordens interesser i omverdenen og fremme det gode naboskab.

Samarbejdet blev formaliseret i 1952 med Nordisk Råds oprettelse som forum for parlamentarikerne og regeringerne i de nordiske lande. I 1962 underskrev de nordiske lande Helsingforsaftalen, som siden har været den grundlæggende ramme for det nordiske samarbejde. I 1971 blev Nordisk Ministerråd oprettet som det formelle forum til at varetage samarbejdet mellem de nordiske regeringer og de politiske ledelser i de selvstyrende områder, Færøerne, Grønland og Åland. 


\section{Indholdsfortegnelse}

Forord

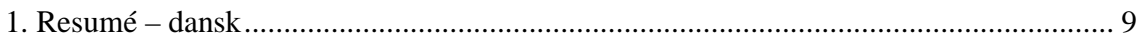

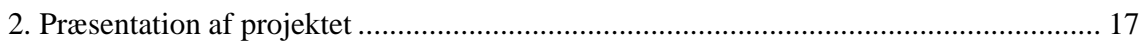

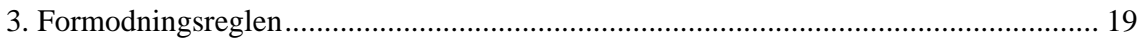

3.1 Implementeringen af direktivets regel i de nordiske lande ................................ 19

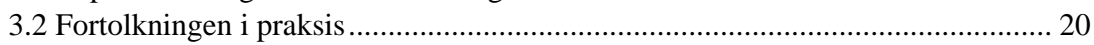

3.2.1 Anvendelsen af hovedreglen (formodning for) .................................... 20

3.2.2 Hvad skal der til, for at formodningen anses for tilbagevist? ................. 34

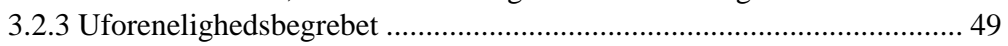

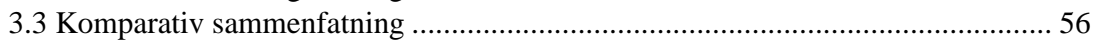

3.4 Kendskab til og praktisering af reglerne i branchen ........................................... 57

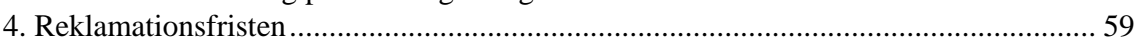

4. 1. Implementeringen og reklamationsreglerne i de forskellige retssystemer .......... 59

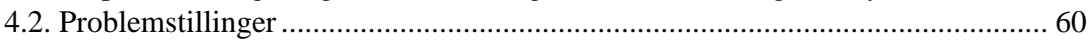

4.3 Bevisbyrde og krav til bevisstyrke efter 6-måneders fristen..................................... 61

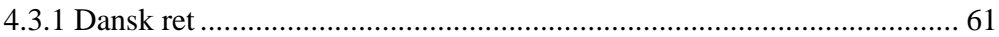

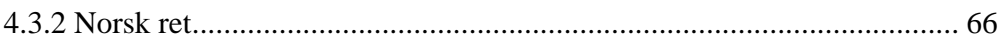

4.3.3 Svensk ret.............................................................................. 70

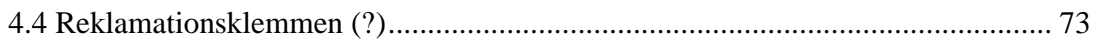

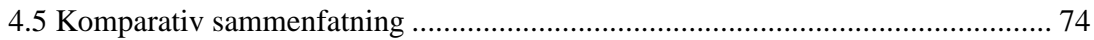

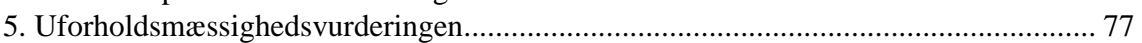

5.1. Implementeringen af direktivets regel i de nordiske lande ................................. 77

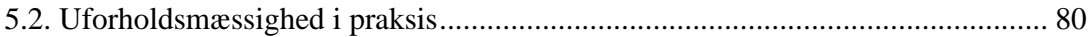

5.2.1 Omlevering som uforholdsmæssig i forhold til afhjælpning (retning) ... 80

5.2.2 Afhjælpning som uforholdsmæssigt i forhold til omlevering.................. 92

5.2.3 Uforholdsmæssighedsvurderingen i andre sammenhænge ..................... 93

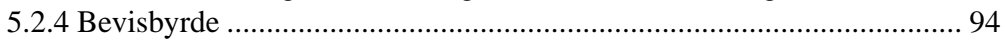

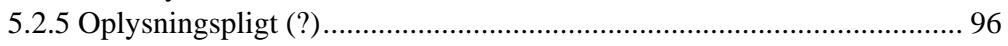

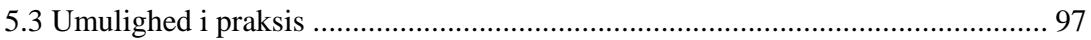

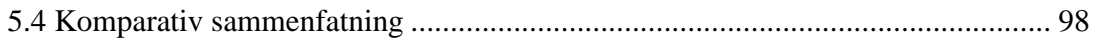

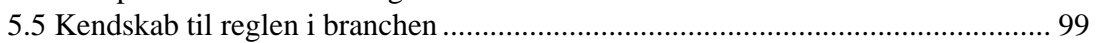

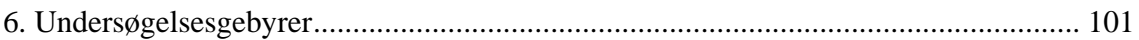

6.1 Emnets relation til forbrugerkøbsdirektivets regler ........................................... 101

6.2 Reguleringen af adgangen til at opkræve undersøgelsesgebyrer i de enkelte

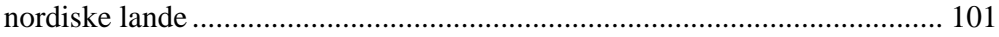

6.2.1 Lovregler i Norge og på Island............................................................ 101

6.2.2 Almindelige principper - retstilstanden i Danmark, Finland og

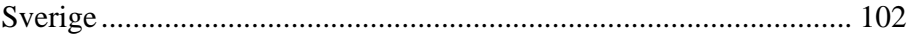

6.2.3 Sammenfattende om betingelserne for at kræve gebyr............................ 102

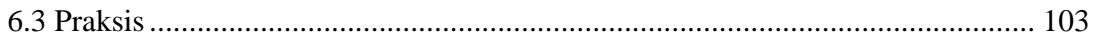

6.3.1 Varen må ikke være mangelfuld - bevisbyrdeforhold......................... 103

6.3.2 Kravet skal være vedtaget mellem parterne........................................ 107

6.3.3 Ugyldighedsregler ...................................................................... 111

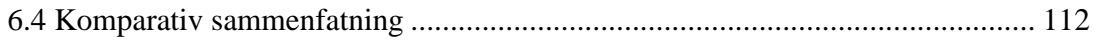

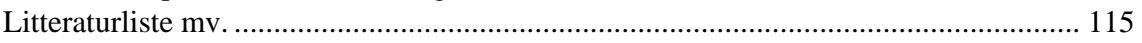

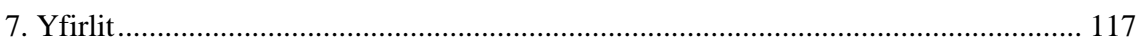

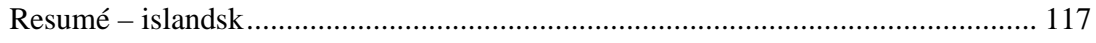

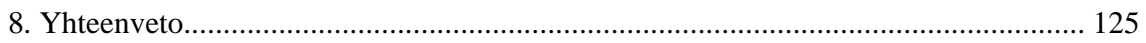

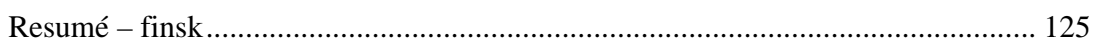

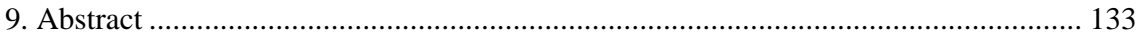

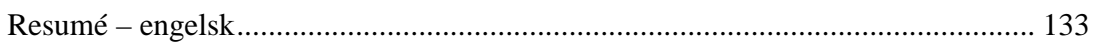


Bilag: Samlet oversigt over retspraksis

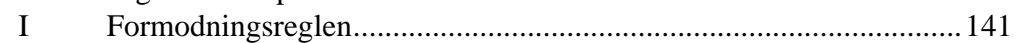

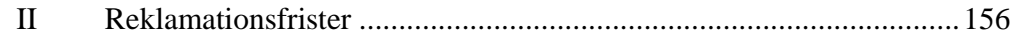

III Uforholdsmæssighedsvurderingen ..................................................... 165 


\section{Forord}

EU-direktiv 1999/44/EF om visse aspekter af forbrugerkøb og garantier i forbindelse hermed indebar ændringer i samtlige nordiske købelovgivninger, og de nye regler har nu fungeret en årrække i praksis.

På den baggrund nedsatte Styringsgruppen for juridiske spørgsmål under EK-Konsument, Nordisk Ministerråd, i begyndelsen af 2005 en projektgruppe bestående af forbrugerrepræsentanter fra de nordiske lande. Formålet med projektet var at belyse de nye reglers anvendelse i praksis. Projektledelsen er blevet varetaget af Charlotte Lemche og Tina Morell Nielsen, begge Forbrugerstyrelsen, Danmark. Øvrige repræsentanter har været Annette Høyrup, Forbrugerrådet, Danmark, Vivian Mikalsen, Forbrukerrådet, Norge, Rebecca Heinemann, Konsumentverket, Sverige, Eirikur A. Eggertsson og derefter Iris Ösp Ingjaldsdottir, begge Forbrugerrådet, Island samt Jukka Kaakkola, Konsumentverket, Finland. Udreder på projektet har været professor Vibe Ulfbeck, Københavns Universitet, bistået af adjunkt Kim Frost, CBS, Danmark.

Projektgruppens medlemmer har bidraget med materiale i form af afgørelser og oplysninger vedrørende de pågældende landes regler på området. Projektgruppen indledte sit arbejde i februar 2005 og afsluttede dette april 2006.

København, maj 2006

Vibe Ulfbeck 



\section{Resumé - dansk}

Ved EU-direktiv 1999/44/EF om visse aspekter af forbrugerkøb og garantier i forbindelse hermed blev i et vist omfang introduceret nye køberetlige regler i forbrugerkøb. Direktivet nødvendiggjorde ændringer i de nordiske køberetlige regler om forbrugerkøb. Direktivets regler blev implementeret i disse lovgivninger, og ændringerne trådte i kraft i perioden 2001 frem til 2003. Formålet med nærværende rapport er at belyse anvendelsen af de nye regler i praksis.

Konkret drejer det sig om fire problemområder, nemlig anvendelsen af den nye formodningsregel, hvorefter en mangel ved en vare inden for de første 6 måneder efter leveringen skal formodes at have været til stede på leveringstidspunktet, direktivets 2-årige reklamationsfrist, direktivets regel om adgangen for forbrugeren til i tilfælde af mangler at vælge mellem omlevering eller afhjælpning, medmindre den ene beføjelse må anses for uforholdsmæssig, samt direktivets regel om kravet på gratis afhjælpning af mangler sammenholdt med praksis i relation til opkrævning af undersøgelsesgebyrer.

Da reglerne er forholdsvis nye, er det begrænset, hvad der findes af praksis om disse. Det er lykkedes at samle godt 100 afgørelser fra de nordiske forbrugerklagenævn, der kan belyse de omhandlede problemer. Det er disse afgørelser, der er gjort til genstand for en nærmere undersøgelse i denne rapport

\section{Formodningsreglen}

Direktivets formodningsregel, hvorefter en mangel, der konstateres inden for de første 6 måneder efter leveringen, skal formodes at have været til stede på leveringstidspunktet, er implementeret på næsten ordret samme måde i de undersøgte retssystemer. Alligevel anvendes reglen på noget forskellig måde i de undersøgte retssystemer. Den mest „direkte“ anvendelse ses i svensk og norsk ret. I disse retssystemer anvendes reglen således uden nogen prøvelse af, om forbrugeren i øvrigt ville være i stand til at bevise eller sandsynliggøre, at manglen forelå på leveringstidspunktet. Dette gælder så vidt ses, uanset hvilken type produkt, der er tale om. Anderledes forholder det sig i dansk og finsk ret. I begge retssystemer - dog mest udtalt i dansk ret - indhentes af klagenævnet fagkyndige erklæringer til belysning af manglen. Herved etableres et grundlag for at foretage en bevisvurdering uafhængigt af formodningsreglen, og det er kendetegnende for begge retssystemer, at man især anvender reglen som en ekstra støtte for forbrugerens sag, hvis forbrugeren ikke fuldt ud har kunnet bevise manglens tilstedeværelse på leveringstidspunktet (finsk ret) eller som regelgrundlag, hvis manglens tilstedeværelse på leveringstidspunktet 
må anses for sandsynliggjort af forbrugeren (dansk ret). For så vidt angår dansk ret kan det dog konstateres, at konkret sandsynliggørelse ikke er en betingelse for anvendelse af formodningsreglen. For eksempel anvendes denne også i sager om tekniske forhold, hvor en oprindelig mangel ikke kan bevises eller sandsynliggøres af forbrugeren, og der samtidig ikke er holdepunkter for at antage, at manglen først er opstået senere. Anvendelsen af sagkyndige erklæringer i finsk og navnlig dansk ret indebærer, at sælgeren som regel vil have bedre praktiske muligheder for at løfte bevisbyrden i disse retssystemer end i norsk og svensk ret.

Det gælder i alle de undersøgte retssystemer, at sælgeren går fri for ansvar, dersom han kan bevise, at manglen ikke forelå på leveringstidspunktet. I mange sager afvises sælgers krav under henvisning til, at denne ikke har ført det fornødne bevis. I andre sager stilles tilsyneladende alene krav om, at sælger skal have „sandsynliggjort“, at fejlen først er opstået senere. Det er imidlertid vanskeligt at sige, om der reelt er forskel på kravene til „bevisets“styrke. Gennemgående er der få sager, hvor det lykkes for sælgeren at blive fritaget for ansvar. De typiske sager drejer sig om beklædningsgenstande, der har været udsat for forkert brug, og dyr, der efterfølgende har pådraget sig sygdomme. For så vidt angår tekniske forhold er det normalt svært for sælger at løfte bevisbyrden. Vedrørende mobiltelefoner findes således kun en enkelt sag, hvor sælger anses for at have løftet bevisbyrden. Normalt kræves i hvert fald, at der foreligger en sagkyndig erklæring til støtte for sælgers sag. I finsk ret findes dog et antal sager, hvor sælger fritages for ansvar til trods for, at en sådan erklæring ikke foreligger. I dansk ret vil der kunne ske afvisning af mobiltelefonsager som bevisuegnede for Forbrugerklagenævnet.

Der findes få sager, der vedrører uforenelighedsbegrebet. Det er især blevet anvendt i sager vedrørende køb og salg af brugte biler. I ingen af sagerne siges det dog klart, at det er uforeneligt med anvendelsen af formodningsreglen, at der er tale om brugte varer. Sagerne drejer sig primært om, hvorvidt manglens karakter indebærer, at der foreligger uforenelighed. To sager angående mobiltelefoner vedrører spørgsmålet, om den omstændighed, at henholdsvis fugt- og vandskade først opstår længere tid efter leveringstidspunktet, indebærer, at manglens art må anses for uforenelig med anvendelsen af formodningsreglen. Dette besvares for så vidt angår vandskaden bekræftende (svensk ret) og for så vidt angår fugtskaden benægtende (norsk ret). Uforenelighedsbegrebet anvendes overvejende i mindre absolut forstand. Dette indebærer, at der er en glidende overgang mellem „uforenelighedstilfælde“ og tilfælde, hvor sælger anses for at have ført bevis for for eksempel forkert brug af et produkt.

For så vidt angår kendskabet til praktiseringen af reglen i branchen foreligger to danske undersøgelser, som til dels synes at pege i forskellige retninger. I en undersøgelse foretaget af CBS konkluderes således, at formodningsreglen sammenfattende synes at have fået større betydning i praksis end tilsigtet og forventet, mens det i en undersøgelse foretaget af 
Forbrugerklagenævnet konkluderes, at tallene peger på, at der er en stor og generel mangel på viden om formodningsreglen“.

\section{Reklamationsfristen}

Ved direktivet blev indført en absolut reklamationsfrist på 2 år fra varens overgivelse. Den tidsmæssige udstrækning af reglen fik kun konkret betydning for Danmark og Island, idet de øvrige nordiske lande på indførelsestidspunktet $\mathrm{i}$ forvejen havde enten en toårsfrist eller en femårsfrist eller slet ingen reklamationsfrist. I 2005 har man endvidere i svensk ret forlænget den toårige frist til en treårsfrist.

I relation til spørgsmålet om bevisbyrdeforhold og bevisstyrke i perioden fra udløbet af seksmåneders reglen og frem til udløbet af reklamationsfristen kan undersøgelsens resultater sammenfattes sådan, at det hos de retsanvendende myndigheder i både Danmark, Norge og Sverige anses for udgangspunktet, at det efter 6-månedersfristens udløb er forbrugeren, der har bevisbyrden for, at en fejl ved et produkt var til stede på tidspunktet for overgivelsen af varen og dermed udgør en mangel. I såvel norsk som svensk ret opereres imidlertid med relativt milde krav til forbrugerens bevisførelse. I norsk ret synes man gennem reglen om sælgerens „bevisføringspligt“ i realiteten at være tæt på at anvende en formodningsregel til fordel for forbrugeren også uden for 6-måneders fristen. Dette kommer i praksis særlig klart frem i sager, der er omfattet af den 5-årige reklamationsfrist. Medmindre der er holdepunkter for, at en fejl ved varen skyldes forbrugerens egne forhold eller lignende, anses forbrugeren for at have løftet bevisbyrden for, at der er tale om en oprindelig mangel. I svensk ret sondres mellem garantitilfælde og andre tilfælde. Er fejlen efter dens karakter omfattet af en garanti, har sælgeren bevisbyrden for, at denne skyldes forbrugerens forhold eller lignende. Er forholdet ikke omfattet af en garanti, har forbrugeren bevisbyrden, men denne lempes, således at det er tilstrækkeligt, at forbrugerens forklaring efter nævnets vurdering fremstår som mere sandsynlig end sælgerens. Hverken i norsk eller svensk ret synes der at være spor af en praksisændring efter indførelsen af formodningsreglen. I norsk ret er den centrale dom på området fortsat Rt 1998.766, og i svensk ret henvises i litteraturen fortsat til de ovenfor refererede afgørelser fra begyndelsen af 1990'erne. Sværere er det at bedømme situationen i dansk ret. Her er det helt afgørende indholdet af den af Forbrugerklagenævnet indhentede sagkyndige erklæring. Som udgangspunkt er det kun, hvis erklæringen er til fordel for forbrugeren, at denne får medhold. Støtter erklæringen den erhvervsdrivende i samme grad, som den støtter forbrugeren, slår reglen om, at bevisbyrden er forbrugerens, igennem, sådan at forbrugeren ikke får medhold, medmindre der gør sig særlige forhold gældende, som for eksempel at der er reklameret kort tid efter udløbet af seks måneders fristen. Alt i alt synes i modsætning til hvad man i lovforarbejderne forventede - i dansk ret at være tale om temmelig strenge krav til forbrugerens bevisbyrde efter 
udløbet af 6-måneders fristen. Forskellene mellem retssystemerne synes navnlig at bero på, at det danske forbrugerklagenævn selv indhenter sagkyndige vurderinger, mens dette som udgangspunkt er overladt til parterne i såvel det norske som det svenske system.

I relation til spørgsmålet om „reklamationsklemmen“ - dvs. det forhold, at sælgerens reklamationsfrist over for producenten kan være kortere end forbrugerens reklamationsfrist over for sælgeren - indeholder samtlige, nordiske retssystemer undtagen det finske, teknisk set kimen til problemet, i og med længden af reklamationsfristerne kan være forskellige i de forskellige led i omsætningskæden. Den empiriske undersøgelse foretaget i Danmark dokumenterer også, at fristerne meget ofte rent faktisk er forskellige. I hvilket omfang dette giver anledning til problemer i praksis, er det imidlertid vanskeligere at danne sig et indtryk af. Af enkelte afgørelser fremgår, at forhandlerens reklamationsmuligheder over for producenten har været berørt som tema i sagen, men der er ikke i den undersøgte praksis tydelige spor af, at forhandleren normalt anser egne reklamationsmuligheder for at være et relevant kriterium i relation til spørgsmålet om forbrugerens rettigheder over for ham. Dette udelukker selvsagt ikke, at denne form for argumentation rent faktisk forekommer i praksis i detailhandlen.

\section{Uforholdsmessighedsvurderingen}

Reguleringen af uforholdsmæssighedskriteriet i direktivets art. 3, stk. 3, er i vid udstrækning imple-menteret identisk i de nordiske lande. Af forskelle, som bør fremhæves, kan for det første nævnes den sproglige fremhævelse i den norske og islandske lovtekst af forbrugerens valgret og for det andet det lovfæstede „fjerde kriterium“ i den svenske lovtekst, hvorefter der ved uforholdsmæssighedsvurderingen skal tages hensyn til, om den alternative beføjelse vil kunne gennemføres med væsentlig lavere omkostninger end den valgte beføjelse. Disse forskelle i detaljerne synes i et vist omfang at blive afspejlet i praksis. Der er ingen praksis om den situation, hvor forbrugeren ønsker afhjælpning frem for omlevering. Det følgende tager derfor sigte på den omvendte situation, hvor forbrugeren ønsker omlevering frem for afhjælpning.

I relation til det overordnede kriterium, hvorefter der skal ses på om omkostningerne forbundet med omlevering er uforholdsmæssige i forhold til omkostningerne forbundet med afhjælpning, er der dansk og norsk praksis for, at omkostningerne ved omlevering som udgangspunkt skal fastsættes til varens indkøbspris for sælgeren. Det er tilsyneladende alene i dansk forbrugerklagenævnspraksis, man er gået videre og har betonet, at det også kan have betydning, om den pågældende vare vil kun genanvendes som let brugt salgsobjekt af sælgeren.

I relation til kriteriet „genstandens værdi“ er der i dansk og norsk ret praksis for, at dette skal forstås sådan, at lav værdi som regel taler for omlevering. Dette udgangspunkt har også støtte i lovforarbejder. Der- 
imod er det mindre klart, hvordan det skal vurderes, om der er tale om en lav værdi eller en høj værdi.

For så vidt angår kriteriet „manglens betydning“ er det i norsk ret fastslået, at der herved skal ses på, om manglen kan karakteriseres som væsentlig for varens funktion.

Hvad angår kriteriet „uden væsentlig ulempe for forbrugeren“ fremgår det af dansk og norsk praksis, at der herved må henses til, hvor hurtigt afhjælpning kan ske, om varen efter afhjælpning vil lide af andre skavanker end rent kosmetiske, og om forbrugeren i det konkrete tilfælde har særlig vanskeligt ved at undvære den pågældende genstand.

Det fremgår endvidere af praksis, at man udover direktivets tre kriterier også anvender andre kriterier ved vurderingen af, om omleveringsbeføjelsen er „uforholdsmæssig“.

Det er et særkende for svensk ret, at man tilsyneladende lægger afgørende vægt på, om gennemførelsen af omlevering vil være „væsentlig mere omkostningsfuld“ for sælgeren end afhjælpning („krone for krone“princippet). Når dette kriterium anvendes i svensk ret og ikke i de andre nordiske lande, må det antages at afspejle, at dette kriterium netop udtrykkeligt er skrevet ind i den svenske lovtekst. Det er interessant at bemærke, at man i den norske Lagmannsretts dom udtrykkeligt har taget afstand fra en meget håndfast anvendelse af dette kriterium. Billedet er således umiddelbart, at det formentlig vil være noget sværere at komme igennem med et omleveringskrav i svensk ret end i norsk ret.

Det er i øvrigt et særkende for norsk ret, at såvel lovforarbejder som domstolsafgørelserne har inddraget betydningen af et miljømæssigt hensyn. Det må i dog anses for noget uklart, hvilken betydning dette hensyn spiller, herunder om miljøhensynet entydigt taler mod omlevering, og om der evt. bør sondres mellem forskellig varekategorier og evt. mellem omlevering af en enkelt vare og hele vareserier.

Den nordiske praksis illustrerer i øvrigt, at uforholdsmæssighedsvurderingen kan være relevant ikke blot i forholdet mellem afhjælpningsbeføjelsen og omleveringsbeføjelsen, men også f.eks. i forholdet mellem afhjælpning og afslag eller afhjælpning og ophævelse.

Det synes at være den almindelige antagelse, at det er sælgeren, der har bevisbyrden for, at en beføjelse, som forbrugeren ønsker at anvende, er uforholdsmæssig. Dette afspejler, at direktivets hovedregel om, at det er forbrugeren, der har valgretten, slår igennem også i de retssystemer, hvor man ikke sprogligt har fremhævet dette i lovteksten. Udslag af dette gennemslag ses også i dansk forbrugerklagenævnspraksis, hvor det - selv om hovedreglen ikke sprogligt er fremhævet i lovteksten - i præmisserne til afgørelserne ofte fastslås, at forbrugeren har valgretten.

Hverken direktivet eller de nordiske lovbestemmelser fastslår, at sælgeren har pligt til at oplyse forbrugeren om dennes valgret i henhold til reglerne. Alligevel viser praksis, at manglende oplysning fra sælgers side kan have skadevirkninger for denne. 
Sammenfattende kan det konkluderes, at selv om uforholdsmæssighedsvurderingen foretages med vægtning af lidt forskellige kriterier i de forskellige nordiske lande, er det overordnede billede, at de retsanvendende myndigheder er opmærksomme på, at forholdsmæssighedsvurderingen skal afspejle den realitetsændring til forbrugerens fordel, som var formålet med de nye lovregler.

Ideelt set burde denne forståelse af reglerne også komme til udtryk i den måde reglerne praktiseres på i branchen. I CBS-undersøgelsen fra 2005 er dette spørgsmål blevet undersøgt, for så vidt angår dansk ret. Det konstateres i undersøgelsen, at reglerne for godt 2/3 af de adspurgtes vedkommende skønnes ikke at have haft nogen effekt, mens de for næsten 1/3 af de adspurgte skønnes at have haft den ønskede effekt om end med varierende intensitet. Resultaterne af undersøgelsen kan give anledning til at rejse spørgsmålet, om den grundlæggende ændring, der består i som udgangspunkt at indrømme forbrugeren valgretten mellem afhjælpning og omlevering, er kommet tilstrækkeligt tydeligt til udtryk i lovteksten. Der foreligger hverken tilsvarende undersøgelser fra norsk eller islandsk ret, der kan belyse spørgsmålet, om den sproglige fremhævelse af valgretten i disse landes lovtekster har påvirket brancheadfærden i højere grad end de danske regler.

\section{Undersøgelsesgebyrer}

Spørgsmålet om den erhvervsdrivendes adgang til at opkræve gebyr for undersøgelser af salgsgen-standen med henblik på at få konstateret, om genstanden lider af en mangel, er i vid udstrækning reguleret identisk i de nordiske lande. Praksis i de lande, som ikke har lovregler herfor (Danmark, Finland og Sverige), svarer indholdsmæssigt til den lovregulering, der findes i andre nordiske lande (Island og Norge).

På baggrund af undersøgelsen af lovgivning og praksis kan det konkluderes, at den erhvervsdrivende i ingen af de nordiske lande kan opkræve et gebyr hos forbrugeren for omkostninger til undersøgelse af salgsgenstanden, såfremt undersøgelsen måtte afsløre, at genstanden lider af en mangel. Forbrugeren har i disse tilfælde krav på at få afhjulpet manglen gratis, jf. hertil Forbrugerkøbsdirektivets art. 3, stk. 2. Den erhvervsdrivende kan derfor alene opkræve et gebyr hos forbrugeren i tilfælde, hvor undersøgelsen ikke afslører tilstedeværelsen af en mangel. Bevisbyrden for, at varen ikke er mangelfuld, påhviler i dansk ret sælgeren. Dette fremgår udtrykkeligt af dansk praksis. Der foreligger ikke praksis, der kan belyse, hvad der gælder i de øvrige nordiske lande, bortset fra svensk ret. Her gælder tilsyneladende ingen særlig bevisbyrderegel vedrørende mangler i relation til spørgsmålet, om der kan kræves undersøgelsesgebyr. Det synes at være de almindelige bevisbyrderegler, der anvendes, således at det som udgangspunkt er forbrugeren, der skal bevise, at der foreligger en mangel, om end bevisbyrdekravet er lempet. 
Efter dansk forbrugerklagenævnspraksis gælder endvidere en særregel for garantitilfælde. I garantitilfælde skærpes kravene til sælgers bevis for, at der ikke er tale om en mangel, som han hæfter for under garantien. En tilsvarende særregel for garantitilfælde ses ikke udviklet i de øvrige nordiske lande, om end sælger efter den svenske konsumentköplags § 23 i garantitilfælde generelt som udgangspunkt bærer bevisbyrden for, at der ikke foreligger mangler. Det gælder derimod generelt, at et undersøgelsesgebyr kun kan kræves, dersom dette har været aftalt mellem parterne senest på tidspunktet for salgsgenstandens indlevering til undersøgelse. I svensk ret synes man i en periode at have anerkendt et aftalevilkår i indleveringssedlen som tilstrækkeligt til at opfylde kravet om vedtagelse. Med en nyere afgørelse må denne praksis imidlertid anses for ændret. Der gælder herefter formentlig samme krav om foretagelsen af en konkret bedømmelse i hvert enkelt tilfælde under inddragelse af en evt. indleveringsseddel i samtlige nordiske lande. Den erhvervsdrivende har under ingen omstændigheder krav på et undersøgelsesgebyr, hvis den foretagne undersøgelse ikke var nødvendig til konstatering af manglen. Endvidere skal undersøgelsesgebyret være rimeligt. Det må således ikke stå i et uforholdsmæssigt forhold til de undersøgelsesforanstaltninger, den erhvervsdrivende skal gennemføre. 



\section{Præsentation af projektet}

Ved EU-direktiv 1999/44/EF om visse aspekter af forbrugerkøb og garantier i forbindelse hermed blev i et vist omfang introduceret nye køberetlige regler i forbrugerkøb. Direktivet nødvendiggjorde ændringer i de nordiske køberetlige regler om forbrugerkøb. Direktivets regler blev implementeret i disse lovgivninger, og ændringerne trådte i kraft sommeren 2002. Formålet med nærværende rapport er at belyse anvendelsen af de nye regler i praksis.

Konkret drejer det sig om fire problemområder, nemlig anvendelsen af den nye formodningsregel, hvorefter en mangel ved en vare inden for de første 6 måneder efter leveringen automatisk skal formodes at have været til stede på leveringstidspunktet, direktivets 2-årige reklamationsfrist, direktivets regel om adgangen for forbrugeren til i tilfælde af mangler at vælge mellem omlevering eller afhjælpning, medmindre den ene beføjelse må anses for uforholdsmæssig, samt direktivets regel om kravet på gratis afhjælpning af mangler sammenholdt med praksis i relation til opkrævning af undersøgelsesgebyrer.

Da reglerne er forholdsvis nye, er det begrænset, hvad der findes af praksis om disse. Det er lykkedes at samle godt 100 afgørelser fra de nordiske forbrugerklagenævn, der kan belyse de omhandlede problemer. Til brug for fremstillingen er udarbejdet referater af samtlige afgørelser, og disse er for nemheds skyld nummereret fortløbende. Referaterne findes optrykt samlet i kronologisk rækkefølge bagest i rapporten.

Det er vigtigt for forståelsen af afgørelserne på forhånd at gøre sig klart, at der gør sig forskellige „processuelle“ forhold gældende i de forskellige nordiske lande. Således er det et særkende for dansk ret, at der automatisk i forbindelse med sagsbehandlingen i forbrugerklagenævnet indhentes en sagkyndig erklæring. Herved adskiller fremgangsmåden ved det danske forbrugerklagenævn sig fra den norske og den svenske fremgangsmåde, hvor det overlades til parterne at skaffe eventuel sagkyndig dokumentation, og til dels også fra den finske fremgangsmåde, hvor der kun fra nævnets side indhentes sagkyndige erklæringer i tvivlstilfælde.

Udover retspraksis sammenfatter rapporten også nogle resultater fra empiriske undersøgelser vedrørende kendskabet til de nye regler i detailleddet. Der foreligger således to danske undersøgelser af denne art, nemlig Bo Kristensen m.fl., „Nye regler om forbrugerkøb - en empirisk undersøgelse“, CBS, 2005 samt Forbrugerstyrelsen, Forbrugerredegørelse 2004, 2004. Der foreligger ikke lignende undersøgelser fra de øvrige nordiske lande, og det har derfor ikke været muligt at udlede noget om oplysningsniveauet generelt i de nordiske lande. 



\title{
3. Formodningsreglen
}

\subsection{Implementeringen af direktivets regel i de nordiske lande}

Direktivets art. 5, stk. 3 fastslår:

\begin{abstract}
„Medmindre andet bevises, skal manglende overensstemmelse, der viser sig senest seks måneder efter varens levering, formodes at have eksisteret på leveringstidspunktet, medmindre denne formodning er uforenelig med varens eller den manglende overensstemmelses art.“
\end{abstract}

Denne regel er implementeret på følgende måder i de nordiske lande:

Dansk ret: købelovens § 77a, stk. 3:

„Viser salgsgenstandens manglende overensstemmelse med kravene i §§ 75a og 76 sig inden seks måneder efter leveringen, formodes den manglende overensstemmelse at have været til stede på det i stk. 1 nævnte tidspunkt, medmindre denne formodning er uforenelig med salgsgenstandens eller den manglende overensstemmelses art.“

Finsk ret: konsumentskyddslagen kap. 5, § 15,2:

„Visar sig ett fel inom sex månader från den tidpunkt då risken för varan gick över på köparen, antas felet ha funnits vid denna tidpunkt, om inte motsatsen bevisas eller detta antagande är oförenligt med felets eller varans art.“

Islandsk ret: lov om forbrugerkøb § 18, stk. 2:

„Såfremt ikke andet bliver bevist, formodes mangel som viser sig inden seks måneder fra risikoens overførsel, for at have været til stede på det tidspunkt, risikoen overgik til forbrugeren. Dette gælder dog ikke hvis denne formodning er uforenelig med mangelens eller salgsgenstandens art.“

Norsk ret: lov om forbrukerkjøp § 18, stk. 2:

„Hvis ikke noe annet bevises, skal en mangel som viser seg innen seks måneder etter risikoens overgang, formodes å ha eksistert ved risikoens overgang. Dette gjelder likevel ikke dersom formodningen er uforenlig med varens eller mangelens art.“ 
Svensk ret: konsumentköplagen § 20a:

„Ett fel som visar sig inom sex månader efter det att varan avlämnades skall anses ha funnits vid avlämnandet, om inte annat visas eller detta är oförenligt med varans eller felets art.“

Den sproglige formulering af formodningsreglen i de nordiske lande er tilnærmelsesvis identisk.

Den norske og den islandske regel er helt ens. I begge regler angives, at medmindre andet bevises, da gælder formodningsreglen. Ifølge andet punktum gælder dette [formodningen] dog ikke, dersom formodningen er uforenelig med varens eller manglens art. Den svenske og den finske regel er struktureret ens, men lidt forskelligt fra den norske og den islandske regel. Såvel den svenske som den finske regel starter med at fastslå, at fejlen „skall antas/anses“ at have foreligget på leveringstidspunktet. Af 2. pkt. fremgår, at dette gælder, medmindre andet bevises, eller det er uforeneligt med varens eller manglens art. De fire regler må antages at have samme indhold. Det kan ikke tillægges betydning, at den svenske regel anvender udtrykket „skall anses”, mens den finske anvender udtrykket „,skal antas“. Hovedreglen er, at man skal gå ud fra, at manglen forelå på leveringstidspunktet. Hovedreglen gælder ikke, dersom sælgeren kan bevise, at dette ikke var tilfældet. Hovedreglen gælder heller ikke, dersom det er uforeneligt med varens eller manglen karakter at gå ud fra, at manglen forelå på leveringstidspunktet.

Den danske regel skiller sig ud fra de øvrige regler derved, at det alene er udtrykkeligt angivet, at formodningsreglen ikke gælder, såfremt formodningen er uforenelig med salgsgenstandens eller den manglende overensstemmelses art. Reglen angiver derimod ikke, som de øvrige, at formodningsreglen ikke gælder, dersom sælger beviser noget andet. Nedenfor under 3.2.2.4 vurderes i hvilket omfang denne sproglige forskel også indebærer forskel på reglernes reelle indhold.

\subsection{Fortolkningen i praksis}

\subsubsection{Anvendelsen af hovedreglen (formodning for)}

\subsubsection{Indledning}

I samtlige nordiske retssystemer er det hovedreglen, at en mangel, der viser sig inden for 6 måneder, skal formodes at have været til stede på leveringstidspunktet. I det følgende undersøges, hvorvidt dette udgangspunkt også afspejles i praksis. Undersøgelsen indbefatter praksis fra Danmark, Norge, Sverige og Finland. Der foreligger ikke praksis fra Island. 


\subsubsection{Svensk ret}

En meget direkte anvendelse af reglen ses i svensk praksis. Flere sager vedrører køb af brugte biler. Det Allmänne Reklamationsnämnden har med de følgende plenumafgørelser lagt linien for, hvordan disse tilfælde skal behandles.

\section{Sag 2003-4989}

En forbruger, A, købte i marts 2003 en brugt bil fra 1995 til SEK 79.500. Tre dage efter leveringen konstaterede A, at bilens automatgearkasse ikke ville skifte fra 2. til 3. gear. Også ved skift fra 1. til 2. gear var der problemer. Fejlen var et tilbagevendende problem i hele foråret 2003. Fejlen blev påtalt over for sælgeren, B, i juni 2003. B ville ikke afhjælpe fejlen, men tilbød en erstatning på SEK 7.000 og en lånebil, mens bilen blev repareret. Dette accepterede A ikke. Der måtte ved bedømmelsen af, hvad en forbruger generelt kan forvente af salgsgenstanden, tages hensyn til salgsgenstandens karakter. Når der er tale om brugte biler, skal der tages hensyn til bilens alder, antal kørte kilometer og pris. Der må også tages hensyn til almindelig slitage. Nævnet udtalte, at det forhold, at en automatgearkasse går i stykker på en bil, som er otte år gammel, og har kørt omtrent 170.000 kilometer, ikke er sædvanligt. Skaden kunne derfor ikke anses for et udslag af almindelig slitage. Da A heller ikke i øvrigt havde haft anledning til at tro, at gearkassen var så slidt, at den ville gå i stykker inden for tre måneder efter leveringen, afveg bilen fra, hvad A med rette kunne forvente, og var derfor mangelfuld. Herefter udtalte nævnet: „Ett fel som visar sig i varan inom sex månader från det att varan avlämnades skall enligt 20 a $\S$ konsumentköplagen anses ha funnits i varan redan vid tidpunkten för avlämnandet. Säljaren skall följaktligen anses ha ansvaret för felet. För att befrias från detta ansvar måsta säljaren visa att varan var felfri när den avlämnades. Sexmånderspresumptionen bryts också om säljaren visar att presumptionen inte är förenlig med varans eller felets art. Det kan vara fallet t.ex. när varans normala livslängd är kortare än sex månader eller om felet beror på ett olycksfall eller felaktig hantering. För att säljaren skall undgå ansvar måsta han därför i ett fall som detta visa att felet inte fanns vid avlämnandet eller att presumptionen är oförenlig med varans eller felets art. .....Säljaren har på sin sida inte presenteret någon utredning som visar att felet inte fanns vid avlämnandet. Säljaren har inte heller visat att presumptionen om fel vid avlämnandet är oförenlig med varans eller felets art”. Nævnet fremhævede i den forbindelse, at den beskrivelse af bilen, som B havde påberåbt sig til støtte for sin afvisning af A's krav, ikke viste andet, end at bilens gearkasse var i normal stand. En sådan beskrivelse af bilen kan indgå i vurderingen af, hvorvidt bilen var mangelfuld ved leveringen, men er den udarbejdet - og er den bagvedliggende undersøgelse af bilen foretaget - af sælgeren, kan den ikke tillægges selvstændig bevisværdi for så vidt angår spørgsmålet om, hvorvidt bilen var mangelfri ved leveringen. På den baggrund fandt nævnet, at B skulle erstatte A’s omkostninger. Afgørelsen var ikke enstemmig.

\section{Sag 2003-5348}

En forbruger, A, købte i januar 2003 en brugt bil til SEK 50.000. Bilen havde ved leveringen kørt 230.000 kilometer. I maj 2003 begyndte kølervandet at løbe direkte igennem køleren. Bilen blev kørt til B, som tilbød at afhjælpe problemet for A's egen regning. Dette ville A ikke acceptere. Efter yderligere kontakt mellem parterne, som ikke førte til en afklaring, blev køleren repareret hos en autoriseret kø- 
lermontør i juni 2003. Prisen herfor var SEK 5.399. Reparatøren angav i fakturaen, at køleren havde været i stykker længe. A forlangte herefter sine omkostninger erstattet af B. B nægtede dette. I den aktuelle sag udtalte nævnet, at det forhold, at en køler går i stykker på en bil, som er otte år gammel og har kørt 230.000 kilometer, ikke er noget, som normalt indtræffer. Der var derfor ikke tale om almindelig slitage, og A havde derfor ikke haft anledning til at regne med fejlen så kort tid efter leveringen. Bilen afveg derfor fra, hvad A med rette havde forventet, og var følgelig mangelfuld. Herefter udtalte nævnet: „Ett fel som visar sig i varan inom sex månader från det att varan avlämnades skall enligt 20 a § konsumentköplagen anses ha funnits i varan redan vid tidpunkten för avlämnandet. Säljaren skall följaktligen anses ha ansvaret för felet. För att befrias från detta ansvar måsta säljaren visa att varan var felfri när den avlämnades. Sexmånaderspresumptionen bryts också om säljaren visar att presumptionen inte är förenlig med varans eller felets art. Det kan vara fallet t.ex. när varans normala livslängd är kortare än sex månader eller om felet beror på ett olycksfall eller felaktig hantering. För att säljaren skall undgå ansvar måsta han därför i ett fall som detta visa att felet inte fanns vid avlämnandet eller att presumptionen är oförenlig med varans eller felets art. .....Säljaren har på sin sida inte presenteret någon utredning som visar att felet inte fanns vid avlämnandet. Säljaren har inte heller visat att presumptionen om fel vid avlämnandet är oförenlig med varans eller felets art”. Nævnet henviste i den forbindelse til, at det fremgik af fakturaen fra kølermontøren, at køleren havde været i stykker længe. Der var derudover indleveret fotos, som bestyrkede kølermontørens oplysning. På den baggrund fandt nævnet, at B skulle erstatte A’s omkostninger til reparationen samt benzinomkostninger. Afgørelsen var ikke enstemmig.

\section{Sag 2004-03-03; 2003-4343}

Klageren købte i februar 2003 en brugt bil til kr. 25.000. Forhandleren oplyste i markedsføringen af bilen, at denne havde fået renoveret topstykket. Da klageren kørte hjem i bilen, opdagede han, at førersædet var nedslidt, og at ryglænet ikke kunne reguleres. El-spejlene kunne heller ikke reguleres, ligesom der viste sig forskellige andre fejl. Fem dage efter købet gik bilen i stå og måtte transporteres på værksted. Den nødvendige reparation beløb sig til kr. 8.069. Forhandleren leverede nogle andre brugte frontsæder og el-spejle, mens klageren selv betalte for monteringen heraf. Klageren krævede nu det fulde beløb erstattet. Forhandleren nægtede dette under henvisning til, at bilen blev leveret nysynet uden anmærkninger. Klageren var blevet informeret om stolenes tilstand. I det hele taget anførte forhandleren, at bilen ikke havde nogen fejl ved leveringen. Det allmänna reklamationsnämnden udtalte, at når der foretages en renovering af en bils topstykke, er det ikke i overensstemmelse med god skik i branchen, hvis drivremmen ikke udskiftes samtidig. Trods bilens alder og almene stand led bilen derfor af en mangel. Herefter udtalte nævnet: „Ett fel som visar sig i varan inom sex månader från det att varan avlämnades skall enligt 20 a $§$ konsumentköplagen anses ha funnits i varan redan vid tidpunkten för avlämnandet. Säljaren skall följaktligen anses ha ansvaret för felet. För att befrias från detta ansvar måsta säljaren visa att varan var felfri när den avlämnades. Sexmånderspresumptionen bryts också om säljaren visar att presumptionen inte är förenlig med varans eller felets art. Det kan vara fallet t.ex. när varans normala livslängd är kortare än sex månader eller om felet beror på ett olycksfall eller felaktig hantering. För att säljaren skall undgå ansvar måsta han därför i ett fall som detta visa att felet inte fanns vid avlämnandet elller att presumptionen är oförenlig med varans eller felets art. .....Säljaren har på sin sida inte presenteret någon utredning som visar att felet inte fanns vid avlämnan- 
det. Säljaren har inte heller visat att presumptionen om fel vid avlämnandet är oförenlig med varans eller felets art”. Da drivremmen brast fem dage efter leveringen, og eftersom forhandleren ikke havde bevist, at drivremmen var fejlfri ved leveringen, eller at formodningen for, at manglen var til stede ved leveringen, var uforenelig med fejlens eller salgsgenstandens art, skulle forhandleren erstatte klageren de reparationsomkostninger, denne havde haft som følge af, at drivremmen brast. Derimod afviste nævnet klagerens øvrige påstande, herunder om at forhandleren skulle betale for monteringen af sæderne og el-spejlene, da der her var tale om fejl, som klageren burde have opdaget før købet

Sagerne illustrerer, at formodningsreglen også anvendes på brugte varer. ${ }^{1}$

Andre sager vedrører beklædningsgenstande.

28. Sag 2003-06-05; 2003-0397

Klageren havde købt en beklædningsgenstand for kr. 799. Anden gang hun anvendte genstanden, opdagede hun, at den havde pletter. Hun antog, at pletterne stammede fra maskinolie, og at de havde været til stede ved leveringen, men at hun ikke havde set dem der på grund af den kunstige belysning i forretningen. Hun ønskede nu at hæve købet. Forhandleren nægtede at efterkomme dette krav og anførte, at klageren selv havde påført pletterne. Det allmänna reklamationsnämnden udtalte, at eftersom forhandleren ikke havde bevist, at pletterne, som måtte anses for en væsentlig mangel, ikke var til stede ved leveringen, måtte manglen antages at have bestået ved leveringen. Klageren havde derfor ret til at hæve købet.

\section{Sag 2004-04-06; 2004-0068}

Klageren havde købt et par støvler til kr. 1.350. Hælen faldt af efter almindelig brug. Klageren reklamerede derfor til forhandleren med krav om ophævelse af købet, hvilket forhandleren afviste. Det allmänna reklamationsnämnden udtalte, at eftersom forhandleren ikke havde bevist, at fejlen, som måtte anses for en væsentlig mangel, der ikke kunne udbedres, ikke var til stede ved leveringen, måtte manglen antages at have bestået ved leveringen. Klageren havde derfor ret til at hæve købet.

Sammenfattende kan konstateres, at i samtlige afgørelser anvendes formodningsreglen direkte i den forstand, at der ikke for at understøtte anvendelsen af reglen foretages en vurdering af, om det også i det konkrete tilfælde forekommer sandsynligt, at manglen forelå på leveringstidspunktet. Der henvises alene til, at den erhvervsdrivende ikke har ført bevis for andet og/eller til, at opstillingen af formodningen ikke kan anses for uforenelig med varens eller manglens art. $^{2}$

\footnotetext{
${ }^{1}$ Se ligeledes sag 19 (norsk ret) refereret nedenfor under 2.2.1.3.

${ }^{2}$ En enkelt sag viser, at det fortsat er forbrugeren, der har bevisbyrden for, at det købte er behæftet med en mangel på tidspunktet, hvor denne påberåbes: (nr. 30) Sag 2004-02-12;2003-6577. Klageren købte en kat den 1. februar 2003. Den 14. juli tog hun katten med til dyrlægen, og to dage senere blev katten aflivet. Klageren ønskede at få købesummen tilbage og at få dækket omkostningerne til aflivning af katten. Sælgeren nægtede dette under henvisning til, at klageren ikke havde fremlagt hverken udtalelse fra dyrlægen eller obduktionsrapport. Det Allmänna Reklamationsnämnden fandt,
} 


\subsubsection{Norsk ret}

I norsk ret ses på samme måde en meget direkte anvendelse af formodningsreglen i følgende afgørelser:

\section{Sak 2004/0382}

Klageren havde købt en beklædningsgenstand, som ca. en måned efter købet viste sig at have en række små huller i sømmene. Derudover var en knap faldet af med et ca. $2 \mathrm{~cm}$ stort skindstykke, et knaphul var revet af, og der var hul i en lomme. Beklædningsgenstanden blev derfor indleveret til forhandleren, som oplyste, at reparationen ville tage ca. en uge. Der gik imidlertid fire uger, før klageren kunne afhente genstanden. Reparationen var ikke tilstrækkelig godt udført, og klageren indleverede derfor atter genstanden til forhandleren. Heller ikke denne gang var reparationen i orden. Forhandleren afviste at foretage omlevering eller at give klageren ret til at hæve købet. Forbrukertvistutvalget fandt, at det fremgår af lov om forbrukerkjøp § 18, stk. 2, at hvis ikke andet bevises, anses en mangel, som viser sig inden seks måneder efter leveringen at have eksisteret på leveringstidspunktet. Derudover havde forhandleren foretaget de to afhjælpningsforsøg, som han efter lovens $\S 30$, stk. 2 har ret til. Han havde derfor ikke ret til at foretage yderligere afhjælpningsforsøg. Klageren kunne derfor hæve købet, da manglen var væsentlig.

I denne sag havde indklagede ikke svaret på Forbrukertvistutvalgets henvendelser, og sagen er derfor primært afgjort på grundlag af klagerens indlæg.

Mange sager drejer sig om mobiltelefoner, der er eller hævdes at være fugtskadede. I norsk ret slår formodningsreglen som udgangspunkt igennem i disse tilfælde.

\section{Sak $2004 / 103$}

Klageren, havde købt en mobiltelefon til kr. 999. Nogle måneder senere konstateredes, at vibratorfunktionen i telefonen ikke virkede efter hensigten. Telefonen blev derfor indleveret til forhandleren, som efter undersøgelse afviste reklamationen under henvisning til, at fejlen skyldtes en fugtskade. Sagen blev indbragt for Forbrukertvistutvalget, hvor forhandleren fremlagde billeder af mobiltelefonen som dokumentation for fugtskaden. Der blev herudover alene fremlagt en af forhandleren indhentet sagkyndig erklæring, hvorefter fejlene skyldtes fugtskade. Forbrukerutvalget fandt det vanskeligt at tolke billederne. Samlet fandt Forbrukertvistutvalget, at det ikke var bevist af forhandleren, at fejlen ved vibratorfunktionen ikke fandtes ved leveringen. Derfor fandtes fejlen at have været til stede ved leveringen. Klageren havde derfor ret til omlevering.

at sælgeren var erhvervsdrivende og dermed omfattet af konsumentköplagen. Nævnet konstaterede herefter, at katten ved købsaftalens indgåelse var ledsaget af en af en dyrlæge udfærdiget helbredserklæring. Da klageren ikke, trods opfordret hertil, havde fremlagt hverken en udtalelse fra den dyrlæge, som foretog aflivningen, eller en obduktionsrapport, havde klageren ikke bevist, at katten, da den blev aflivet, havde en sådan sygdom eller lignende, at den måtte anses for mangelfuld i lovens betydning. Nævnet afviste derfor klagerens krav. 
I denne sag var det ikke helt klart, om fejlen faktisk skyldtes fugtskade eller andre forhold. For Forbrukertvistutvalget forelå alene billedmateriale (af mindre god kvalitet) og en sagkyndig udtalelse indhentet af forhandleren som dokumentation for fugtskaden. På dette grundlag kunne det ikke anses for bevist af forhandleren, at fejlen ikke havde været til stede allerede på leveringstidspunktet. Afgørelsen kan læses sådan, at formodningsreglen anvendes, fordi der ikke er dokumentation for, at fejlen skyldes en fugtskade. I andre sager lægges imidlertid til grund, at der er tale om fugtskade, men alligevel anvendes formodningsreglen til forbrugerens fordel.

\section{Sag $2004 / 03 / 26$}

Forbrugeren købte i juni 2003 en mobiltelefon. Dagen efter købet opdagede han, at o-tasten ikke virkede ordentligt. Han reklamerede imidlertid ikke, idet han skulle på ferie. Han reklamerede derfor først i august 2003, hvor telefonen blev indleveret til forhandleren. Primo september 2003 fik han besked om, at telefonen led af en fugtskade, og at reparationen ville koste mere end NKR 3.000. Forbrugeren ønskede at hæve købet. Forbrukertvistutvalget udtalte, at det måtte lægges til grund, at svigtet skyldtes en fugtskade, men at der ikke var grundlag for at fastslå, hvorvidt skaden var opstået før eller efter risikoens overgang. Herefter citerede man formodningsreglen og udtalte, at udvalget, da man ikke kunne anse det for bevist, at skaden var opstået efter risikoens overgang, og da man heller ikke kunne anse det for uforeneligt med varens eller manglens art at antage, at der var tale om en oprindelig mangel, måtte lægge dette til grund. Manglen måtte således anses for at have foreligget ved leveringen. Forbrugeren fik derfor ret til at hæve købet, da manglen ikke var uvæsentlig.

I denne sag blev fejlen konstateret allerede dagen efter leveringen. Det forekommer på den baggrund ikke overraskende, at Forbrukertvistutvalget når frem til, at skaden må formodes at have været til stede også på leveringstidspunktet. ${ }^{3}$ I andre sager, hvor fejlfunktionen først opstår senere, når man imidlertid til samme resultat.

\section{Sag $2004 / 02 / 57$}

Forbrugeren købte i marts 2003 en mobiltelefon. I september 2003 (inden for 6 måneders fristen) opdagede forbrugeren en fejl ved telefonen, og han reklamerede derfor til forhandleren, hvor telefonen også blev indleveret. Forhandleren videresendte telefonen til en reparatør, som fandt, at telefonen led af en fugtskade, og at det ikke kunne betale sig at udbedre skaden. Forbrugeren ønskede derfor nu at hæve købet. Forhandleren afgav ikke udtalelse i sagen, som derfor primært blev afgjort på baggrund af forbrugerens sagsfremstilling. Forbrukertvistutvalget udtalte, at man lagde til grund, at der var tale om en fugtskade. Man fandt endvidere ikke holdepunkter for at antage, at skaden skyldtes fejl begået af forbrugeren. Under henvisning til formodningsreglen fandt man herefter, at det måtte lægges til grund, at der var tale om en oprindelig mangel. Da afhjælpning ikke havde været aktuelt, havde forbrugeren ret til at hæve købet, idet manglen ikke var uvæsentlig.

\footnotetext{
${ }^{3}$ Sagen bør sammenholdes med den danske sag nr. 13a, refereret nedenfor under 3.2.1.4.
} 


\section{Sag $2004 / 03 / 61$}

Forbrugeren købte en mobiltelefon i april 2003. I august 2003 indleverede han telefonen til forhandleren pga. funktionssvigt. Telefonen blev sendt til en reparatør i England, som oplyste, at telefonen havde været i vand. Forbrugeren kunne kun få telefonen tilbage, hvis hun betalte NKR 300. Forbrugeren ønskede at hæve købet. Forbrukertvistutvalget indledte med at henvise til formodningsreglen og udtalte herefter, at siden udvalget ikke kunne anse det for bevist, at forbrugeren havde påført telefonen fugtskaden, fandtes manglen at have eksisteret på leveringstidspunktet. Det tilføjedes, at det ikke fandtes bevist, at forbrugeren havde udøvet en brug af telefonen, som var udover det normale. Da afhjælpning ikke var aktuelt, og da manglen ikke var uvæsentlig, kunne forbrugeren hæve købet.

\section{Sag $2004 / 03 / 72$}

Forbrugeren købte i april 2003 en mobiltelefon. Omkring to måneder efter købet kunne telefonen ikke længere oplades. Angiveligt reklamerede forbrugeren samme dag, som problemet opstod, til forhandleren, som henviste ham til en reparatør. Reparatøren undersøgte telefonen og fandt, at den havde en fugtskade. En senere undersøgelse viste, at det ikke kunne betale sig at reparere telefonen. Efter at forbrugeren havde klaget til Forbrukertvistutvalget, tilbød forhandleren at erstatte forbrugerens omkostninger forbundet med manglen, reparatørens udgifter forbundet med undersøgelsen og fragt til reparatøren. Forbrugeren ville imidlertid også have en anden telefon. I klagen til Forbrukertvistutvalget krævede forbrugeren, at købet blev hævet, samt erstatning. Forbrukertvistutvalget lagde til grund, at der var tale om en fugtskade. Udvalget udtalte herefter, at det ikke var bevist, at fugtskaden var opstået, mens telefonen var i forbrugerens varetægt. Det tilføjedes: „Det er heller ikke påvist noe som tilsier at svikt skulle inntre straks fukt var kommet inn i telefonen, og at telefonen ikke kunne fungere i så lang tid som i denne saken, inntil skaden eventuelt utviklet seg dithen at svikten inntrådte”. Manglen måtte med andre ord anses for at have foreligget ved leveringen. Forbrugeren fik derfor ret til at hæve købet, da manglen ikke var uvæsentlig. Erstatningen blev skønsmæssigt fastsat.

I samtlige sager anvendes formodningsreglen, selv om det lægges til grund, at der er tale om fugtskade, og selv om der er gået længere tid fra leveringstidspunktet, og til fejlen viser sig. ${ }^{4}$

Sammenfattende kan konkluderes, at formodningsreglen i norsk ret som i svensk ret anvendes direkte, uden at der først foretages en konkret vurdering af sandsynligheden for, at manglen forelå på leveringstidspunktet.

\subsubsection{Dansk ret}

I dansk ret anvendes formodningsreglen tilsyneladende på en lidt anden måde. Det er et gennemgående træk, at der indledningsvis i afgørelserne redegøres for indholdet af formodningsreglen i § 77a, stk. 3. Inden reglen

\footnotetext{
${ }^{4}$ I svensk praksis har man i fugtskadesagerne anset det for „uforeneligt” med manglens art, at denne skulle have foreligget på leveringstidspunktet, hvis der er gået længere tid mellem leveringstidspunktet og funktionssvigtet. Begrundelsen herfor er, at man antager, at fejlen ville have vist sig før, hvis der havde været tale om en fugtskade allerede på leveringstidspunktet, jf. nærmere nedenfor under afsnit 3.2.3 om ,uforenelighed”.
} 
anvendes, foretages imidlertid på baggrund af sagkyndige erklæringer en vurdering af, om det i det konkrete tilfælde forekommer sandsynligt, at manglen forelå på leveringstidspunktet. Som eksempler kan nævnes følgende sager:

\section{Sag $2002-521 / 7-88$}

En forbruger, A, købte i juni 2002 en brugt bil, som 2 måneder efter leveringen på et tidspunkt, hvor A havde kørt ca. 3.000 km., brød i brand og udbrændte. A klagede til den erhvervsdrivende, B, som afviste A's klage, idet han ikke mente, at A havde bevist, at der var tale om en fejl, der havde været til stede på leveringstidspunktet, og at A i øvrigt burde have bemærket de symptomer, der måtte have været forud for branden, og have reageret på dem. A indbragte herefter sagen for Forbrugerklagenævnet. Forbrugerklagenævnet udtalte for det første, at det forhold, at bilen var købt som beset og afprøvet og med oplysning om, at diverse fejl og mangler kunne forekomme, ikke afskar A fra at gøre mangelsindsigelser gældende, hvis bilen ved leveringen havde ikke-forventelige fejl, såsom fejl af sikkerhedsmæssig karakter. Den af nævnet udpegede sagkyndige fandt, at branden med overvejende sandsynlighed opstod i anledning af, at en benzinslange var flækket på grund af mørning, og nævnet konstaterede herefter, at der var tale om en sikkerhedsmæssig fejl, som ikke var opstået pludseligt, hvorfor det fandtes sandsynligt, at slangen havde været defekt allerede på leveringstidspunktet. Da klageren ikke havde afkrceftet formodningen for, at manglen forelå allerede på leveringstidspunktet, fandt nævnet, at købet kunne hæves, selv om bilen ikke kunne tilbageleveres i væsentlig samme stand, idet dette skyldtes bilens egen beskaffenhed på leveringstidspunktet.

\section{Sag 2003-590/7-42}

Klageren havde købt en hundehvalp, som allerede dagen efter fik diarré og måtte behandles af dyrlæge. Behandlingen hjalp ikke, og klageren kontaktede derfor en ny dyrlæge, der konstaterede, at hunden led af Isospora Canis. Dyrlægen foretog derudover en operation, da det befrygtedes, at hunden havde slugt et fremmedlegeme. Klageren forlangte, at den erhvervsdrivende godtgjorde dyrlægeudgifterne, men den erhvervsdrivende ville alene godtgøre en mindre del. Forbrugerklagenævnet udtalte, blandt andet under henvisning til en udtalelse fra Det Veterinære Sundhedsråd, at det var sandsynligt, at hunden var smittet med Isospora Canis på leveringstidspunktet. Da den erhvervsdrivende herefter ikke havde afkræftet formodningen for, at sygdomsanlægget var til stede på leveringstidspunktet, lagde nævnet til grund, at hunden var behæftet med en mangel ved leveringen. Nævnet bestemte, at klageren var berettiget til at forholdsmæssigt afslag på kr. 2.000. Da den erhvervsdrivende ikke kendte eller burde have kendt til sygdomsanlægget ved leveringen, fik klageren derimod ikke godtgjort dyrlægeudgifterne.

\section{Sag 2002-62/7-89}

En læderlap, der var en væsentlig del af en skodesign, faldt af inden for den første måned efter købet. Forbrugerklagenævnet fandt det på baggrund af sagkyndige erklæringer sandsynliggjort, at læderlappen ikke havde været tilstrækkeligt fastgjort ved skoens fabrikation. Sælgeren havde herefter ikke afkræftet formodningen for, at kvalitetsafvigelsen havde været til stede på leveringstidspunktet. Skoe- 
ne var derfor mangelfulde ved leveringen, og da manglen var væsentlig kunne købet af skoene hæves.

\section{Sag $4031 / 7-364$}

Klageren havde købt en pc til kr. 8.693. 2 1⁄2 uge efter leveringen åbnede klageren kassen med pc'en og konstaterede, at fronten var knækket, og at cd-romdrevet støjede, når cd'en blev aflæst. Klageren reklamerede flere gange i ugerne derefter men blev afvist. Af den sagkyndige erklæring fremgik, at skaden mindede meget om en beskadigelse tilføjet ved et fald, slag eller stød, f.eks. under transport. Senere oplystes fra den sagkyndiges side, dels at emballagen til computeren ikke havde været beskadiget, da han modtog den til undersøgelse, dels at revnen i computeren (fronten) var vanskelig at konstatere ved en hurtig visuel inspektion. På den baggrund fandt nævnet det ikke sandsynligt, at skaden skulle være sket under hjemtransporten. Under henvisning hertil og under henvisning til formodningsreglen, fandt nævnet herefter, at det påhvilede den erhvervsdrivende at godtgøre, at revnen i fronten var sket, mens pc'en var i klagerens besiddelse, og således ikke var til stede på leveringstidspunktet. Da den erhvervsdrivende ikke havde løftet denne bevisbyrde, fandt nævnet, at der forelå en mangel, som berettigede klageren til et passende afslag på kr. 1.500 .

I samtlige ovenstående sager lægger man tilsyneladende ikke uden videre til grund, at manglen forelå på leveringstidspunktet, blot fordi der er reklameret inden for seksmåneders fristen. I stedet når man på baggrund af en konkret vurdering frem til, at det må anses for sandsynligt, at manglen var til stede allerede på leveringstidspunktet, hvorefter dette med hjemmel i § 77a, stk. 3, antages at have været tilfældet.

Det kan dog ikke udledes af afgørelserne, at det er en betingelse for at anvende formodningsreglen, at forbrugeren konkret har sandsynliggjort, at manglen forelå på leveringstidspunktet. Det kan være tilstrækkeligt, at dette ikke kan afvises. Dette fremgår blandt andet af følgende afgørelser:

\section{Sag 2002-4031/7-2134}

En forbruger, A, købte hos en erhvervsdrivende, B, en processor og et systemkort (bundkort). A forsøgte forgæves at få delene til at fungere. A returnerede herefter delene til B. Efter en undersøgelse nægtede B imidlertid at erstatte komponenterne, idet B henviste til, at A havde beskadiget dem under monteringen. A afviste dette. Af den sagkyndige erklæring fremgik, at der var sket en nedsmeltning af processorens ben som følge af „overclocking”, som sker ved ændringer af forskellige indstillinger og placeringer i systemkortet. For så vidt angik processoren fandt nævnet, at nedsmeltningen af denne måtte have været synlig for sælgeren ved indlevering til reparation, dersom den allerede havde været beskadiget af A på dette tidspunkt. Det måtte derfor påhvile B at godtgøre, at den fysiske beskadigelse var sket før levering. Denne bevisbyrde havde B ikke løftet, hvorfor det måtte lægges til grund, at skaden først var sket efter indleveringen til undersøgelse. For så vidt angik systemkortet, fremgik det af den sagkyndige udtalelse, at det ikke kunne afvises, at dette havde været en returvare, som ikke havde levet op til standardopsætningen ved kortets levering til A. På denne baggrund og under henvisning til formodningsreglen, fandt nævnet herefter, at det måtte påhvile B at godtgøre, at 
ændringerne i kortet var foretaget, mens dette var i forbrugerens besiddelse. Da B ikke kunne løfte denne bevisbyrde, fik forbrugeren medhold.

\section{Sag 2002-613/7-277}

En forbruger, A, havde købt en cardigan, og klagede inden for den første måned efter købet over, at tre ud af fire filtbogstaver på cardiganen var blevet beskadiget efter vask. Den erhvervsdrivende, B, mente, at beskadigelsen skyldtes, at A havde fejlbehandlet cardiganen, hvilket A afviste. Cardiganen blev i forbindelse med behandlingen i Forbrugerklagenævnet besigtiget af næevnets sagkyndige, som ikke med sikkerhed kunne fastslå, hvad årsagen til skaderne var. Det kunne på den baggrund ikke afvises, at det konstaterede skyldtes mangler ved varen. Forbrugerklagencevnet fandt herefter, at B ikke havde afkrcftet formodningen for, at skaden skyldtes forhold, som var til stede ved leveringen, og nævnet fandt derfor, at cardiganen var væsentlig mangelfuld. A kunne derfor hæve købet.

Også den følgende sag synes at afspejle en mere direkte anvendelse af formodningsreglen:

$$
\text { 10. Sag 2003-620/7-47 }
$$

Klageren havde købt et par børnestøvler til kr. 699. Knapt et halvt år efter købet gik lynlåsen i stykker. Klageren reklamerede, men den erhvervsdrivende afviste reklamationen. Forbrugerklagenævnet udtalte, at da der var reklameret inden 6 måneder efter leveringen, måtte det lagges til grund, at fejlen havde varet til stede ved leveringen. Da der var tale om en mangel, havde klageren derfor krav på et passende afslag på kr. 300. Derimod kunne klageren ikke forlange købet hævet, da manglen ikke var væsentlig.

Da der er reklameret inden for 6 måneder, lægges til grund, at manglen var til stede på leveringstidspunktet. Argumentationen svarer til den, der findes i de svenske og norske afgørelser, refereret ovenfor under 3.2.1.2 og 3.2.1.3.

I sager vedrørende mobiltelefoner anvendes formodningsreglen imidlertid i dansk ret på en markant mindre direkte måde end i de sammenlignelige norske sager. Som eksempel kan nævnes følgende sag, hvor Forbrugerklagenævnet afviste:

\section{3a. Sag 4051/7-652}

En forbruger købte d. 1. april 2004 en mobiltelefon. Dagen efter opdagede forbrugeren, at der var fejl i displayet, idet det blev utydeligt og forsvandt. Forbrugeren reklamerede d. 5. april, men sælgeren afviste reklamationen under henvisning til, at der var sivet væske ind i displayet. Nævnet indhentede en sagkyndig udtalelse hvoraf fremgik, at telefonen havde været udsat for væskepåvirkning i form af fugt eller kondens som følge af temperatursvingninger. Det fremgik endvidere, at der ikke var noget, der tydede på materiale- eller konstruktionsfejl. Den sagkyndiges konklusion var, at det måtte anses for ,mest sandsynligt, at der foreligger en skade opstået som følge af klagerens brug af telefonen”. Forbrugerklagenævnet fandt på denne baggrund ikke at kunne træffe afgørelse i sagen uden yderligere bevisførelse, hvorfor sagen blev afvist. 
Sagen minder om den norske sag nr. 17, refereret ovenfor under 3.2.1.3., hvor fejlen også blev konstateret allerede dagen efter købet, og hvor forbrugeren fik medhold. I den danske sag, fastslog den sagkyndige erklæring imidlertid, at det måtte anses for mest sandsynligt, at skaden skyldtes uhensigtsmæssigt brug. Afgørelsen må læses sådan, at der herefter ikke var grundlag for at anvende formodningsreglen. Sagen er i denne forstand udtryk for en mindre direkte anvendelse af formodningsreglen end den norske afgørelse. Sagen viser imidlertid også, at den omstændighed, at formodningsreglen ikke kan anvendes, ikke nødvendigvis er ensbetydende med, at den erhvervsdrivende får medhold. Sagen kan være af en sådan art, at den ikke egner sig til afgørelse af Forbrugerklagenævnet og derfor afvises.

Sammenfattende kan konstateres, at sagkyndige erklæringer fremskaffes af Forbrugerklagenævnet og automatisk indgår i nævnets afgørelser. Formodningsreglen kombineres i den danske praksis i de fleste tilfælde med, at der på baggrund af den sagkyndige erklæring foretages en konkret vurdering af sandsynligheden for, at manglen var til stede på leveringstidspunktet.

Fremgår det af den sagkyndige erklæring, at det må anses for sandsynligt, at manglen var til stede på leveringstidspunktet, vil nævnet som regel tilslutte sig denne vurdering og på dette grundlag nå til, at formodningen for manglens tilstedeværelse på leveringstidspunktet ikke er afkræftet af sælger, hvorefter det antages, at manglen forelå på leveringstidspunktet.

Formodningsreglen giver forbrugeren en bevislempelse derved, at der ikke stilles krav om, at forbrugeren skal bevise, at manglen var til stede på leveringstidspunktet. Det er tilstrækkeligt, at dette på baggrund af den sagkyndige erklæring (fortsat) anses for sandsynligt.

Foretagelsen af den konkrete sandsynlighedsvurdering i sagerne 1, 3 og 8 som grundlag for anvendelsen af formodningsreglen kan umiddelbart synes at stemme mindre godt overens med indholdet af denne regel, i den forstand at konkret sandsynliggørelse for manglens tilstedeværelse på leveringstidspunktet burde være overflødig i henhold til formodningsreglen. Foretagelsen af den konkrete sandsynlighedsvurdering må imidlertid ses som udtryk for, at man i dansk forbrugerklagenævnspraksis ikke vil anvende formodningsreglen i de tilfælde, hvor dette ikke er nødvendigt, fordi der faktisk kan føres bevis for, at manglen var til stede på leveringstidspunktet. En henvisning til, at manglens tilstedeværelse på leveringstidspunktet må anses for bevist, udgør for så vidt blot en „overbegrundelse” af resultatet set i lyset af formodningsreglen.

Foretagelsen af en konkret sandsynlighedsvurdering som grundlag for afgørelserne kan ikke siges at være i strid med formodningsreglen, så længe vurderingen ikke danner grundlag for en afvisning af forbrugerens krav med den begrundelse, at forbrugeren ikke har kunnet bevise, at manglen forelå på leveringstidspunktet. Sådanne begrundelser forekom- 
mer heller ikke i praksis. Tværtimod viser praksis, at det ikke er nødvendigt, at det konkret anses for sandsynligt, at manglen forelå på leveringstidspunktet. Selv om der ikke kan etableres konkrete holdepunkter for en sådan antagelse, er formodningsreglen således blevet anvendt, jf. for eksempel sagerne 6, 7, 10 og 11. Sandsynlighedsvurderingen kan således ses som et led i overvejelsen om, hvorvidt den i KBL opstillede formodning kan anses for tilbagevist af den erhvervsdrivende (se nærmere nedenfor under 3.2.2.4). Såvel i sag 1 som 3 henvises således udtrykkeligt til, at man på baggrund af sandsynlighedsvurderingen „herefter” ikke kan nå til, at den erhvervsdrivende har ,afkræftet formodningen” for, at manglen forelå på leveringstidspunktet. Forbrugerklagenævnet sammenfatter i Forbrugerredegørelsen 2002, p. 59 selv sin praksis sådan, at „...formodningsreglen anvendes i tilfælde, hvor det ikke kan udelukkes, at fejlen var til stede på leveringstidspunktet, men hvor det på den anden side heller ikke er bevist. Samtidig må det ikke anses for mere sandsynligt, at fejlen skyldes forkert brug......... Sag 13a viser, at den omstændighed, at der ikke er tilstrækkelige holdepunkter for at anvende formodningsreglen, ikke nødvendigvis er ensbetydende med, at den erhvervsdrivende får medhold. Sagen kan være af en sådan art, at den ikke egner sig til afgørelse af Forbrugerklagenævnet og derfor afvises.

\subsubsection{Finsk ret}

I finsk ret er der to eksempler på, at formodningsreglen ikke anvendes direkte (men kun indledningsvis i forbindelse med en generel redegørelse for retsgrundlaget), da det anses for bevist, at manglen forelå på leveringstidspunktet:

\section{Sag $02 / 31 / 1617$}

En forbruger købte den 4.1.2002 et par vintersko til sin datter. Efter en måned gik en af skoenes låse i stykker, hvilket den erhvervsdrivende reparerede vederlagsfrit. Et par måneder efter købet sprak skoenes overlæder. Den erhvervsdrivende sendte skoene til en skomager, som konstaterede, at skoene havde været udsat for en hård brug, og at de ikke længere kunne repareres. Forbrugeren krævede herefter enten et par nye sko eller en ophævelse af købet. Konsumentklagonämnden undersøgte skoene og fandt, at skoenes ydermateriale ikke var egnet til vinterbrug. Nævnet udtalte herefter, at eftersom skomaterialet var behæftet med fejl, anså nævnet det for klargjort, at der forelå en mangel, som den erhvervsdrivende var ansvarlig for, og at manglen forelå allerede ved leveringen. Da manglen ikke kunne afhjælpes, og da omlevering ikke var mulig, havde forbrugeren ret til at hæve købet.

\section{Sag $02 / 31 / 2285$}

En forbruger købte den 30.4.2002 et par støvler. I henhold til varedeklarationen bestod støvlernes såler mv. af læder. Forbrugeren anvendte støvlerne en enkelt gang udendørs på et tidspunkt, hvor gaden var delvis fugtig. Efter en halv times brug var støvlerne meget nedslidte. Forbrugeren henvendte sig derefter til den erhvervsdrivende, som afviste klagen med den begrundelse, at der måtte være tale 
om en brugsfejl. Forbrugeren krævede, at købet skulle ophæves, og at hun fik erstattet rejseomkostninger. Konsumentklagonämnden undersøgte støvlerne og fandt, at de var forsynet med så tynde såler, at de alene var egnede til indendørs brug. Da forbrugeren ikke var informeret herom ved købet, forelå der en mangel. Nævnet fandt herefter, at den erhvervsdrivende skulle afhjælpe manglen ved at påsætte nye såler mv.

I det første tilfælde lægger nævnet efter besigtigelse til grund, at det anvendte materiale har været uegnet til formålet. Man anser det også for bevist (klargjort), at manglen forelå på leveringstidspunktet. Det er derfor ikke nødvendigt at henvise direkte til formodningsreglen som begrundelse for resultatet. Tilsvarende gjaldt i den anden sag, hvor manglen bestod $\mathrm{i}$, at der ved købet var givet mangelfuld information. Heraf følger i sagens natur, at manglen forelå på leveringstidspunktet, hvorfor det ikke er nødvendigt at henvise til formodningsreglen.

Også i den følgende sag anvendes formodningsreglen alene på det helt generelle plan:

\section{Sag $04 / 36 / 735$}

En forbruger købte i januar 2004 tre akvariefisk. Kort tid efter købet underrettede forbrugeren sælgeren om, at sygdommen hvid prikkesyge nu fandtes i hans akvarium. Forbrugeren påstod, at sygdommens tilstedeværelse var forårsaget af de indkøbte fisk, hvorfor han krævede erstatning for fiskedød mv. for i alt 141,50 EUR. Sælgeren afviste dette. Nævnet udtalte, under henvisning til 5 kap. 12 § og 5 kap. $15 \S$ i konsumentskyddslagen og idet man citerede formodningsreglen, at en smitsom sygdom hos en solgt fisk kan udgøre en mangel, idet man dog måtte tage hensyn til, at der var tale om levende dyr. Nævnet fandt, at fiskene, henset til hvor hurtigt efter leveringen sygdommen viste sig, led af en mangel på leveringstidspunktet. Da sælgeren ikke havde afhjulpet eller foretaget omlevering, havde forbrugeren, idet der var tale om en væsentlig mangel, ret til at hæve købet og kræve erstatning. Erstatningen blev fastsat til 20 EUR, idet nævnet bemærkede, at forbrugeren til en vis grad havde udvist egen skyld, idet akvariet, allerede inden de indkøbte fisk blev sat ud, var overfyldt, havde dårlig vandkvalitet mv.

I de følgende afgørelser var det ikke helt så klart, at manglen forelå på leveringstidspunktet:

\section{Sag $02 / 36 / 2236$}

En forbruger købte den 2.5.2002 en hundehvalp. Hvalpen døde den 6.5.2002. Ifølge en sagkyndig erklæring døde hvalpen som følge af en infektion, forårsaget af en særlig sygdom. Forbrugeren krævede at få sine penge tilbage, hvilket den erhvervsdrivende afviste. Konsumentklagonämnden konstaterede, at hvalpens sygdom var en mangel. Ifølge en sagkyndig erklæring måtte det lægges til grund, at manglen havde været til stede på leveringstidspunktet. Under henvisning til denne erklæring samt til formodningsreglen, fandt nævnet også, at manglen havde været til stede ved leveringen. Da den erhvervsdrivende ikke kunne modbevise dette, havde forbrugeren ret til at hæve købet. 
45. Køb af brugt personbil (ikke nummereret)

En forbruger købte en 7 år gammel personbil, der havde kørt $173.000 \mathrm{~km}$. for 11.600 euro. 2 måneder efter leveringen gik bilens katalysator i stykker. Forbrugeren krævede, at sælgeren dækkede udgifterne til en ny katalysator. Sælgeren afviste dette under henvisning til, at skaden måtte antages at skyldes køberens uhensigtsmæssige brug. Der forelå en udtalelse fra det værksted, som køberen havde fået til at reparere bilen. Det fremgik heraf, at bilens katalysator var smeltet, og dette ikke ville ske, medmindre der havde været fejl i anordningen for brændselstilførsel. Nævnet anførte, at det måtte anses for sandsynligt, at de fejlagtige indstillinger af motoren, som værkstedet havde påpeget, havde bidraget til skaden, og at sælgeren ikke havde bevist, at de fejlagtige indstillinger skulle være forårsaget af køberen. På dette grundlag og under henvisning til formodningsreglen lagde nævnet herefter til grund, at der havde været tale om en oprindelig mangel, hvorfor sælgeren var ansvarlig.

Der forelå i disse sager en sagkyndig erklæring indhentet af nævnet, ifølge hvilken man vurderede, at manglen forelå på leveringstidspunktet. Under henvisning til denne erklæring og til formodningsreglen, lagde nævnet herefter dette til grund. Formodningsreglen synes i disse sager nærmest anvendt som en ekstra støtte for resultatet.

I en enkelt sag synes formodningsreglen at have været udslagsgivende:

41. Reparation af en cykelfælg (ikke nummereret)

En forbruger, A, købte i april 2003 en cykelfælg til baghjulet på en cykel for EUR 50. To måneder efter købet begyndte fælgens eger pludselig at gå af, hvorfor A henvendte sig til sælgeren, B, med krav om afhjælpning. B konstaterede, at der var en fejl i fælgens nav, og lovede at fremsende fælgen til sin leverandør med henblik på reparation inden for garantiperioden. Da A kom for at hente fælgen oplyste B imidlertid, at afhjælpningen kostede EUR 30, da der ikke var nogen garanti på cykeldele. A krævede herefter at få tilbagebetalt de EUR 30, han havde betalt, og at der skulle gives gratis service på fælgen i 6 måneder. Konsumentklagonämnden citerede formodningsreglen og konstaterede, at fælgen var gået i stykker efter to måneders brug. Da B ikke havde oplyst, hvad manglen på fælgen var forårsaget af, og således ikke havde dokumenteret, at manglen var forårsaget af $\mathrm{A}$, afgjorde nævnet, at B skulle tilbagebetale de EUR 30 til A, som han havde betalt for afhjælpningen.

Sammenfattende kan fremhæves, at man i finsk praksis ikke anvender formodningsreglen direkte, hvis det følger af manglens natur (materialefejl eller manglende instruktion), at manglen forelå på leveringstidspunktet. I så fald konstateres blot, at dette var tilfældet. Er der umiddelbart tvivl om, hvorvidt manglen forelå på leveringstidspunktet, har man i de ovenfor refererede sager ikke alene forladt sig på formodningsreglen, men derudover indhentet en sagkyndig erklæring. Selv om det fremgik af den sagkyndige erklæring, at manglen forelå på leveringstidspunktet, anså man det tilsyneladende ikke herved for bevist, at dette var tilfældet, 
men henviste yderligere til formodningsreglen til støtte for resultatet. I en enkelt sag anvendes formodningsreglen direkte.

\subsubsection{Komparativ sammenstilling}

Den klareste afspejling af formodningsreglen ses i svensk og norsk praksis. Det fremgår udtrykkeligt af præmisserne til afgørelserne, at manglen formodes at have været til stede på leveringstidspunktet, medmindre den erhvervsdrivende beviser andet, eller der foreligger uforenelighed.

I dansk ret tegner der sig et mere sammensat billede. Sagkyndige erklæringer fremskaffes af Forbrugerklagenævnet og indgår automatisk i nævnets afgørelser. Formodningsreglen kombineres i den danske praksis i de fleste tilfælde med, at der på baggrund af den sagkyndige erklæring foretages en konkret vurdering af sandsynligheden for/bevisførelse for, at manglen var til stede på leveringstidspunktet. Betydningen af formodningsreglen træder derfor i dansk ret først tydeligt frem, når det ikke allerede på baggrund af den sagkyndige erklæring kan lægges til grund, at manglen forelå på leveringstidspunktet, men dette på den anden side heller ikke kan udelukkes.

Noget tilsvarende synes at gøre sig gældende i finsk ret. Også her undlader man tilsyneladende at anvende formodningsreglen direkte, hvis der faktisk kan føres bevis for manglens tilstedeværelse på leveringstidspunktet.

\subsubsection{Hvad skal der til, for at formodningen anses for tilbagevist?}

\subsubsection{Indledning}

Det fremgår udtrykkeligt af den norske, islandske, svenske og finske regel, at formodningsreglen ikke skal anvendes, dersom det bevises, at manglen ikke forelå på leveringstidspunktet. Det forekommer endvidere at være den naturlige læsning af disse regler, at formodningsreglen - i fravær af uforenelighed - også kun kan tilsidesættes, dersom der føres et sådant bevis. At der skal føres bevis for, at manglen ikke forelå på leveringstidspunktet, indebærer i praksis, at det er scelgeren, der skal bevise dette.

Det er noget mindre klart, hvordan den danske regel skal forstås. Reglen nævner således ikke som de øvrige nordiske regler udtrykkeligt, at sælger kan sætte formodningsreglen ud af kraft på anden måde end ved at påvise, at formodningen ville være uforenelig med varens eller den manglende overensstemmelses art.

Det oprindelige forslag til den svenske regel svarede til den nuværende danske regel med formuleringen: 
„Ett fel som visar sig inom sex månader efter det att varan avlämnades skall anses ha funnits vid avlämnandet, om detta inte är oförenligt med varans eller felets art.“ 5

I den endelige formulering valgte man imidlertid at præcisere adgangen for sælgeren til også på anden vis at føre bevis for, at manglen ikke var til stede på leveringstidspunktet. Som begrundelse anføres:

\footnotetext{
„I den foreslagna paragrafen återges undantaget avseende varans och den britande avtalsenlighetens art. Däremot finns ingen antydan om att presumtionen i andre fall kan motbevisas. För att nå bättre överensstämmelse med direktivet föreslår Lagrådet att paragrafen formuleres på följanda sätt: „Ett fel som visar sig inom sex månader efter att varan avlämnades skall anses ha funnits vid avlämnandet, om inte säljaren visar att detta inte var fallet eller det av varans eller felets art framgår att felet inte fanns vid avlämnandet“
}

Som det fremgår foretages ændringen alene for at opnå „bedre“ overensstemmelse med direktivet. Også den danske regel må læses i lyset af direktivet. Der er ikke holdepunkter for at antage, at det har været meningen, at der efter den danske regel ikke på anden vis skulle kunne føres bevis af sælgeren for, at manglen ikke var til stede på leveringstidspunktet. I betænkningen anføres i overensstemmelse hermed:

„Det er således forudsat, at sælgeren efter omstændighederne vil kunne tilbagevise formodningen med den følge, at forbrugeren skal godtgøre, at der forelå en mangel på leveringstidspunktet“. ${ }^{6}$

Det må på denne baggrund lægges til grund, at det - til trods for den anderledes formulering af den danske regel - har været hensigten, at det også efter denne regel skal være muligt for sælgeren på anden vis at godtgøre, at der ikke er grundlag for at anvende formodningsreglen

I samtlige retssystemer er det interessante spørgsmål herefter, hvilke krav der stilles til styrken af det bevis, som sælgeren skal føre. De ovenfor under 3.2.1 behandlede afgørelser inddrages i et vist omfang igen til belysning af tilfælde, hvor det ikke er lykkedes for sælger at løfte bevisbyrden. Til sammenligning inddrages endvidere andre afgørelser, hvor det $e r$ lykkedes for sælger at løfte bevisbyrden.

\subsubsection{Svensk ret}

\section{Generelt}

Der er ikke i de svenske forarbejder gjort særskilt bemærkning om kravet til styrken af det bevis, som sælger skal føre. I litteraturen bemærkes, at bevisbyrden ofte vil være tung for sælgeren, allerede fordi forbrugeren typisk vil sidde inde med varen. ${ }^{7}$

\footnotetext{
${ }^{5}$ Prop. 2001/02:134, Bilag 3, ad 20a§.

${ }^{6}$ Betænkning 1403/2001, p. 88.

${ }^{7}$ Johnny Herre, Konsumentköplagen, En kommentar, 2. udgave, 2004, p. 251.
} 
Sager, hvor scelger ikke har opfyldt beviskravet

I samtlige sager refereret ovenfor under 3.2.1.2 (16, 17, 18 og 21) anvendes i præmisserne formuleringen, at det ikke af sælgeren er „bevist”, at manglen ikke forelå på leveringstidspunktet. Det er vanskeligt at vurdere, hvilke krav der stilles til bevisets styrke. I ingen af sagerne var der forelagt sagkyndige erklæringer, der kunne belyse spørgsmålet om manglens tilstedeværelse på leveringstidspunktet. Bevisvurderingen foretages alene på grundlag af varens fremtræden for nævnet og på baggrund af parternes indlæg. I ingen af sagerne forekom det på forhånd usandsynligt, at manglen - efter dens karakter - skulle have foreligget på leveringstidspunktet. Hovedindtrykket synes at være, at det som udgangspunkt ikke er muligt for sælger at løfte bevisbyrden under disse omstændigheder.

Af sag nr. 17 (om maskinolie på en beklædningsgenstand) kan det formentlig udledes, at det ikke gør nogen forskel, om det umiddelbart måtte synes mindre sandsynligt, at den pågældende mangel efter dens art forelå på leveringstidspunktet. Beviskravet fastholdes også i denne situation.

\section{Sager, hvor scelger har opfyldt beviskravet}

I en enkelt sag lægger man til grund, at sælger har opfyldt beviskravet.

26. Sag 2004-03-03; 2003-4991

Klageren havde købt en brugt bil for kr. 108.000. Da klageren kørte bilen hjem efter købsaftalens indgåelse konstaterede han, at der forekom spændingsfald i bilens elektroniske installationer. Al belysning inde i bilen og bilens lygter blinkede. I tiden efter købet kunne han endvidere høre en hvinende lyd i motoren, som tog til i styrke, hvorefter drivremmen til generatoren og vandpumpen brast. Bilen blev indleveret på værksted, som konstaterede, at to ud af tre tandhjul, som holdt remmen på plads, ikke fungerede efter hensigten. Dette havde ført til, at drivremmen var blevet overophedet og sluttelig var bristet. Værkstedet oplyste, at et af tandhjulene havde været i stykker i længere tid. Efter at have fået bilen retur fra værkstedet opdagede klageren forskellige andre fejl ved bilen. Han kontaktede derfor forhandleren, som imidlertid ikke ville betale for udbedring. Han henviste til, at han var fri for ansvar, som blev opdaget efter leveringen, idet der var foretaget en test af bilen hos Svensk Bilprovning, hvor fejlen ikke blev fundet. Nævnet lagde til grund, at der forelå en køberetlig mangel ved bilen. Nævnet udtalte herefter: „Ett fel som visar sig i varan inom sex månader från det att varan avlämnades skall enligt 20 a § konsumentköplagen anses ha funnits i varan redan vid tidpunkten för avlämnandet. Säljaren skall följaktligen anses ha ansvaret för felet. För att befrias från detta ansvar måste säljaren visa att varan var felfri när den avlämnades. Sexmånderspresumptionen bryts också om säljaren visar att presumptionen inte är förenlig med varans eller felets art. Det kan vara fallet t.ex. när varans normala livslängd är kortare än sex månader eller om felet beror på ett olycksfall eller felaktig hantering. För att säljaren skall undgå ansvar måste han därför i ett fall som detta visa att felet inte fanns vid avlämnandet eller att presumptionen är oförenlig med varans eller felets art”. Nævnet fandt, at eftersom forhandleren gennem fremlæggelse af testen fra Svensk Bilprovning havde bevist, at fejlene ikke var til stede ved leveringen, kunne nævnet ikke give klageren medhold i, at forhandleren skulle betale for reparationen eller for bjærgningsomkostningerne. 
Som det fremgår, var det afgørende i denne sag, at der forelå en sagkyndig erklæring, som kunne anses som dokumentation for, at manglen ikke forelå på leveringstidspunktet. ${ }^{8}$

Sammenfattende kan konstateres, at sprogbrugen i de svenske afgørelser er konsekvent. I samtlige afgørelser anvendes udtrykket „bevist”. Formodningsreglen slår igennem også i tilfælde, hvor det ud fra manglens karakter umiddelbart kunne synes at forekomme mindre sandsynligt, at manglen forelå på leveringstidspunktet. Der foreligger et enkelt eksempel på, at den erhvervsdrivende anses for at have løftet bevisbyrden for, at manglen ikke var til stede på leveringstidspunktet. Det afgørende i denne sag var, at der forelå en sagkyndig erklæring, som var udarbejdet i forbindelse med salget af bilen.

\title{
3.2.2.3 Norsk ret
}

\section{Generelt}

Spørgsmålet om kravene til bevisets styrke berøres i de norske forarbejder. Det hedder her:

\begin{abstract}
„Dersom selgeren gjennom sin dokumentasjon avkrefter formodningen, vil det være opp til kjøperen å vise at fejlen likevel forelå ved risikoens overgang. Loven stiller ikke bestemte krav til hvordan selgeren skal sannsynliggjøre at fejlen ikke kan føres tilbake til risikoens overgang. I praksis kan selgeren avbevise formodningen ved å dokumentere påregnelig komponentslitasje. Også en mer generell henvisning til alminnelige og mer eller mindre velkjente erfaringer for vedkommende produkttype kan være tilstrekkelig. Men helt generelle påstander om at slike ting ikke varer lengre, uten dokumentasjon som underbygger påstanden, kan ikke godtas.“ 9
\end{abstract}

Som det fremgår, lægges til grund, at kravet om bevis kan opfyldes ved, at sælgeren „afkræfter formodningen“ gennem sandsynliggørelse af, at fejlen ikke forelå på leveringstidspunktet. Når sandsynliggørelse er tilstrækkelig, er det klart, at forbrugeren herefter må have mulighed for at føre modbevis, dvs. bevise at fejlen alligevel forelå på leveringstidspunktet.

Sager, hvor scelger ikke har opfyldt beviskravet

Til trods for, at det af forarbejderne fremgår, at det er tilstrækkeligt for den erhvervsdrivende at sandsynliggøre, at manglen først opstod efter leveringstidspunktet, findes i norsk ret flere afgørelser, hvor det i præmisserne ligesom i de svenske afgørelser, udtrykkeligt angives som begrundelse for at afvise sælgerens krav, at denne ikke har „bevist“, at manglen ikke var til stede på tidspunktet for leveringen, se således sagerne 14, 15, 17, 19 og 21.

En stor del af sagerne angår spørgsmålet, om der har været tale om mulig forkert brug fra forbrugerens side af teknisk udstyr (mobiltelefoner,

\footnotetext{
${ }^{8}$ Sagen skal sammenholdes med sagerne 24, 25 og 21 refereret ovenfor under 3.2.1.3.

${ }^{9}$ Ot.prp.nr.44 (2001-2002) under bemærkningerne til § 18, p. 175.
} 
17, 18, 19 og 20.) Det fremgår klart af disse sager, at sælger ikke anses for at have løftet sin bevisbyrde, blot fordi han har dokumenteret, at der foreligger en fugtskade. Dette gælder selv i tilfælde, hvor der er gået længere tid fra leveringen og til fejlfunktionen viser sig, og det derfor umiddelbart kan fremstå som mere sandsynligt, at skaden er tilføjet efter leveringstidspunktet. Formodningen til forbrugerens fordel slår således i disse sager relativt stærkt igennem.

\title{
Sager, hvor scelger har opfyldt beviskravet
}

I en enkelt sag lykkedes det for sælgeren at løfte bevisbyrden.

\section{Sak $2003 / 622$}

\begin{abstract}
Klageren havde købt en mobiltelefon for kr. 99. Nogle af telefonens taster ophørte med at fungere 4 dage efter købet. Klageren indleverede derfor telefonen til forhandleren, som oplyste, at telefonen måtte sendes til reparation. Klageren fik herefter besked om, at telefonen var fugtskadet, at det ikke var muligt at reparere den. Forbrukertvistutvalget afviste klagerens påstand om omlevering. Forhandleren havde underbygget sin påstand om fugtskade med fremlæggelse af erklæringer fra eksterne aktører, som samstemmende oplyste, at telefonen efter deres opfattelse var fugtskadet. Forbrukertvistutvalget udtalte på den baggrund: „, Utvalget har generelt inntatt det standpunkt at en mobiltelefon må kunne tåle slik fuktighet som den utsettes for ved vanlig bruk over tid ved temperatursvingninger, kondens m.v., og at det indikerer en iboende svakhet ved telefonen hvis den ikke tåler dette. I nærværende sak er sitasjonen imidlertid en annen. Utvalget viser til de samstemmige uttalelserne fra A Novo Norge A/S, Nokia og Expert Norge A7S og legger til grunn at apparartet rett og slett er blitt væskeskadet. Spørgsmålet er, om skaden er påført før eller etter levering og Utvalget finner det lite sannsynlig at den kan være påført før kjøbet. Det vises i så måte til Experts uttalelse on innpakningen, transporten til forhandleren og oppbevaringen sentrallager. Det fremstår da som mest sannsynlig at mobiltelefonen er blitt utsatt for en mindre ansamling av vann eller annen væske i den korte tiden den har vært i klagers besittelse. Han har således ikke kunnet sannsynliggjøre at det hefter noen relevant kjøpsrettslig mangel ved den, og forholdet kvalifiserer heller ikke for misligholdelsesbeføyelser af noen art. Klagen tas derfor ikke til følge”.
\end{abstract}

Til forskel fra de øvrige mobiltelefonsager lægges her til grund, at telefonen ikke bare er blevet fugtskadet, men „rett og slett blitt væskeskadet”. På denne baggrund og på baggrund af tre fagerklæringer konkluderes, at det anses for mest sandsynligt, at telefonen er blevet udsat for denne vandskade i forbrugerens ejertid. Det er med andre ord lykkedes for sælgeren at afkræfte formodningen for en oprindelig mangel. Da forbrugeren herefter ikke havde kunnet sandsynliggøre, at det forholdt sig anderledes, kunne han ikke gives medhold.

Sammenfattende kan konkluderes, at man i norsk ret fastholder kravet om, at der må føres bevis fra sælgers side for, at manglen ikke forelå på leveringstidspunktet. Dette udgangspunkt fastholdes ligesom i svensk ret, også selv om det ud fra manglens karakter (fugtskader ved mobiltelefoner) umiddelbart kunne synes at forekomme mindre sandsynligt, at mang- 
len var oprindelig. I sag nr. 15 anses sælger for at have løftet sin bevisbyrde derved, at det på baggrund af flere fagerklæringer må anses for det „mest sandsynlige“, at manglen først er opstået efterfølgende.

\subsubsection{Dansk ret}

\section{Generelt}

Som ovenfor nævnt (afsnit 3.2.2.1) kan den anderledes formulering af den danske regel ikke antages at indebære, at det har været intentionen at afskære sælgeren fra at føre bevis for, at manglen ikke forelå på leveringstidspunktet. Den omstændighed, at den danske bestemmelse ikke udtrykkeligt stiller krav om, at der skal føres bevis fra sælgerens side, hvis formodningsreglen ikke skal anvendes, indebærer derimod, at man kan rejse spørgsmålet, om der i dansk ret i videre omfang end i de øvrige nordiske lande er mulighed for at undgå en anvendelse af reglen. Dette kan også formuleres som spørgsmålet, om der stilles lempeligere krav til styrken af det bevis, som sælgeren skal levere.

I betænkningen anføres :

„Det er således forudsat, at sælgeren efter omstændighederne vil kunne tilbagevise formodningen med den følge, at forbrugeren skal godtgøre, at der forelå en mangel på leveringstidspunktet“. ${ }^{10}$

Anvendelsen af udtrykket „tilbagevise formodningen“ og tilføjelsen af, at forbrugeren i disse tilfælde skal godtgøre, at der forelå en mangel på leveringstidspunktet kunne tyde på, at det kan være tilstrækkeligt til at undgå en anvendelse af formodningsreglen, at sælger blot har sandsynliggjort, at manglen ikke forelå på leveringstidspunktet. ${ }^{11}$

Denne fortolkning er tilsyneladende lagt til grund i Forbrugerredegørelse 2004, s. 47, hvor det hedder:

„Hvis sælgeren sandsynliggør, at fejlen ikke var til stede på leveringstidspunktet, kan formodningsreglen ikke anvendes. I det tilfælde har køberen igen bevisbyrden for, at manglen var til stede på leveringstidspunktet“.

Praksis tegner dog ikke noget helt klart billede af, hvordan reglen fortolkes. For sammenlignelighedens skyld sondres i det følgende mellem forskellige type af varer.

PC (tekniske forhold)

I følgende to sager anvendes udtrykket, at sælger må „godtgøre“

\footnotetext{
${ }^{10}$ Betænkning 1403/2001, p. 88.

${ }^{11}$ Sml. den norske sag nr. 16, refereret ovenfor, hvorefter bevisbyrden var løftet i og med det måtte anses for det mest sandsynlige, at manglen var efterfølgende.
} 


\section{Sag 2002-4031/7-2134}

En forbruger, A, købte hos en erhvervsdrivende, B, en processor og et systemkort (bundkort). A forsøgte forgæves at få delene til at fungere. A returnerede herefter delene til B. Efter en undersøgelse nægtede B imidlertid at erstatte komponenterne, idet B henviste til, at A havde beskadiget dem under monteringen. A afviste dette. Af den sagkyndige erklæring fremgik, at der var sket en nedsmeltning af processorens ben som følge af „overclocking”, som sker ved ændringer af forskellige indstillinger og placeringer i systemkortet. For så vidt angik processoren fandt nævnet, at nedsmeltningen af denne måtte have været synlig for sælgeren ved indlevering til reparation, dersom den allerede havde været beskadiget af A på dette tidspunkt. Det måtte derfor påhvile B at godtgøre, at den fysiske beskadigelse var sket før levering. Denne bevisbyrde havde B ikke løftet, hvorfor det måtte lægges til grund, at skaden først var sket efter indleveringen til undersøgelse. For så vidt angik systemkortet, fremgik det af den sagkyndige udtalelse, at det ikke kunne afvises, at dette havde været en returvare, som ikke havde levet op til standardopsætningen ved kortets levering til A. På denne baggrund og under henvisning til formodningsreglen, fandt nævnet herefter, at det måtte påhvile B at godtgøre, at ændringerne i kortet var foretaget, mens dette var i forbrugerens besiddelse. Da B ikke kunne løfte denne bevisbyrde, fik forbrugeren medhold.

\section{Sag $4031 / 7-364$}

Klageren havde købt en pc til kr. 8.693. 2 1⁄2 uge efter leveringen åbnede klageren kassen med pc'en og konstaterede, at fronten var knækket, og at cd-romdrevet støjede, når cd'en blev aflæst. Klageren reklamerede flere gange i ugerne derefter men blev afvist. Af den sagkyndige erklæring fremgik, at skaden mindede meget om en beskadigelse tilføjet ved et fald, slag eller stød, f.eks. under transport. Senere oplystes fra den sagkyndiges side, dels at emballagen til computeren ikke havde været beskadiget, da han modtog den til undersøgelse, dels at revnen i computeren (fronten) var vanskelig at konstatere ved en hurtig visuel inspektion. På den baggrund fandt nævnet det ikke sandsynligt, at skaden skulle være sket under hjemtransporten. Under henvisning hertil og under henvisning til formodningsreglen, fandt nævnet herefter, at det påhvilede den erhvervsdrivende at godtgøre, at revnen i fronten var sket, mens pc'en var i klagerens besiddelse, og således ikke var til stede på leveringstidspunktet. Da den erhvervsdrivende ikke havde løftet denne bevisbyrde, fandt nævnet, at der forelå en mangel, som berettigede klageren til et passende afslag på kr. 1.500 .

I sagerne pegede de sagkyndige erklæringer enten på, at det ikke var sandsynligt, at fejlene var efterfølgende eller på, at det ikke kunne afvises, at manglen var oprindelig. I ingen af sagerne ansås sælgeren for at have løftet sin bevisbyrde blot gennem angivelse af mulige alternative forklaringer på fejlene.

I sag 13a, hvor fejlen opstod dagen efter købet, var det heller ikke tilstrækkeligt, at den sagkyndige erklæring konkluderede, at det var mest sandsynligt, at fejlen skyldtes brugerfejl, idet sagen afvistes som bevisuegnet for Forbrugerklagenævnet. 
13a. Sag 4051/7-652

En forbruger købte d. 1. april 2004 en mobiltelefon. Dagen efter opdagede forbrugeren, at der var fejl i displayet, idet det blev utydeligt og forsvandt. Forbrugeren reklamerede d. 5. april, men sælgeren afviste reklamationen under henvisning til, at der var sivet væske ind i displayet. Nævnet indhentede en sagkyndig udtalelse hvoraf fremgik, at telefonen havde været udsat for væskepåvirkning i form af fugt eller kondens som følge af temperatursvingninger. Det fremgik endvidere, at der ikke var noget, der tydede på materiale- eller konstruktionsfejl. Den sagkyndiges konklusion var, at det måtte anses for „mest sandsynligt, at der foreligger en skade opstået som følge af klagerens brug af telefonen“. Forbrugerklagenævnet fandt på denne baggrund ikke at kunne træffe afgørelse i sagen uden yderligere bevisførelse, hvorfor sagen blev afvist.

\section{Beklcedningsgenstande}

i. Sager, hvor sælger ikke har opfyldt beviskravet

Flere sager drejer sig om klager over beklædningsgenstande, herunder sko. Et afgørende moment i disse sager vil ofte være, om der er tegn på forkert brug fra forbrugerens side. En skavank ved en vare, der skyldes forkert brug, er i forarbejderne ${ }^{12}$ til formodningsreglen nævnt som eksempel på tilfælde, hvor manglens art kan anses for uforenelig med antagelsen af, at manglen var til stede på leveringstidspunktet. I de følgende sager ses spørgsmålet om forkert brug dog alene inddraget som moment $\mathrm{i}$ forbindelse med vurderingen af, om sælger har afkræftet formodningen for manglens tilstedeværelse på leveringstidspunktet.

\section{Sag 2002-62/7-89}

En læderlap, der var en væsentlig del af en skodesign, faldt af inden for den første måned efter købet. Forbrugerklagenævnet fandt det på baggrund af sagkyndige erklæringer sandsynliggjort, at læderlappen ikke havde været tilstrækkeligt fastgjort ved skoens fabrikation, idet læderlappen normalt ikke ville kunne trækkes af uden at det medførte ødelæggelse af skoen, hvilket der ikke var tegn på.. Sælgeren havde herefter ikke afkræftet formodningen for, at kvalitetsafvigelsen havde været til stede på leveringstidspunktet. Skoene var derfor mangelfulde ved leveringen, og da manglen var væsentlig kunne købet af skoene hæves.

Denne sag viser, at formodningen i hvert fald fastholdes, når det på trods af sælgers indvendinger på baggrund af sagkyndige erklæringer stadig må anses for sandsynligt, at manglen forelå på leveringstidspunktet.

Formodningen for at fejlen forelå på leveringstidspunktet, fastholdes imidlertid i videre omfang end dette. Dette kan udledes af den følgende afgørelse, hvor spørgsmålet var, hvorvidt den pågældende skavank skyldtes fabrikationsfejl eller efterfølgende slid evt. som følge af forkert brug fra forbrugerens side.

\footnotetext{
${ }^{12}$ Betænkning 1403/2001, p. 86-87.
} 


\section{Sag 2002-613/7-277}

En forbruger, A, havde købt en cardigan, og klagede inden for den første måned efter købet over, at tre ud af fire filtbogstaver på cardiganen var blevet beskadiget efter vask. Den erhvervsdrivende, B, mente, at beskadigelsen skyldtes, at A havde fejlbehandlet cardiganen, hvilket A afviste. Cardiganen blev i forbindelse med behandlingen i Forbrugerklagenævnet besigtiget af nævnets sagkyndige, som ikke med sikkerhed kunne fastslå, hvad årsagen til skaderne var. Det kunne på den baggrund ikke afvises, at det konstaterede skyldtes mangler ved varen. Forbrugerklagenævnet fandt herefter, at B ikke havde afkræftet formodningen for, at skaden skyldtes forhold, som var til stede ved leveringen, og nævnet fandt derfor, at cardiganen var væsentlig mangelfuld. A kunne derfor hæve købet.

Der var her tvivl hos den sagkyndige om, hvorvidt skaden hidrørte fra en fabrikationsfejl eller fra forkert behandling fra forbrugerens side. Tvivlen kommer i sagen forbrugeren til gode derved, at sælger ikke anses for at have „afkræftet formodningen“ for tilstedeværelsen af fejlen på leveringstidspunktet.

\section{ii. Sager, hvor sælger har opfyldt beviskravet}

4. Sag 2003-62/7-60

En forbruger, A, købte et par spidssnudede sko, hvor overlæderet efter kort tids brug var slidt. A reklamerede til den erhvervsdrivende, B, efter tre dage. B afviste klagen, hvorfor A indbragte sagen for Forbrugerklagenævnet. Forbrugerklagenævnet fandt efter besigtigelse med sagkyndig bistand, at skoenes specielle design indebar en risiko for, at de lange tånæser kunne beskadiges ved almindelig brug. Da skaden måtte antages at skyldes, at skoene havde været udsat for brug, som de ikke var egnede til, havde B afkræftet formodningen for, at der skulle foreligge fabrikations- eller materialefejl, hvilket intet tydede på. Følgelig afvistes kravet.

\section{Sag 2002-62/7-1386}

En forbruger, A, der havde købt et par skatersko til sin søn, reklamerende til den erhvervsdrivende, $\mathrm{B}$, da skoenes såler på mindre end to måneder var slidt igennem. B afviste klagen, idet der efter hans opfattelse var tale om slid. A indbragte herefter sagen for Forbrugerklagenævnet. Forbrugerklagenævnet fandt efter besigtigelse med sagkyndig bistand, at eftersom der var tegn på, at skoene var blevet brugt forkert - det måtte blandt andet antages, at de var snøret forkert, hvilket øgede sliddet på hælen, og at A's søn også havde anvendt skoene efter reklamationstidspunktet - måtte det konstaterede antages at skyldes ekstraordinært slid. B havde dermed afkræftet formodningen for, at der skulle foreligge fabrikations- eller materialefejl, hvilket intet tydede på. A fik derfor ikke medhold i det fremsatte krav om købets ophævelse

I disse to sager var der, i modsætning til sagen om cardiganen, fysiske tegn på forkert brug af varen, og de sagkyndige erklæringer støttede denne antagelse. I disse sager kunne den erhvervsdrivende med andre ord „afkræfte formodningen“ for manglens tilstedeværelse på leveringstidspunktet ved at påvise tegn på forkert brug, idet det herefter blev lagt til 
grund af Forbrugerklagenævnet, at skaden faktisk var sket ved forkert brug.

Sammenfattende kan konstateres, at når der ikke er tegn på forkert brug, skal der meget til, for at sælger har løftet bevisbyrden for, at manglen ikke forelå på leveringstidspunktet. Sælgerens ansvar (formodningen) fastholdes i hvert fald, når det må anses for „sandsynligt“ (sag 1), at skaden var til stede på leveringstidspunktet, men også når blot det „ikke kan afvises” (sag 6), at manglen var der. Når der er tegn på forkert brug, fremstår sælgers bevisopgave som mindre byrdefuld. Støtter de sagkyndige erklæringer antagelsen om forkert brug, lægges dette tilsyneladende til grund af Forbrugerklagenævnet, og forbrugerens krav afvises.

Dyr

To sager vedrører klager over købte dyr, der er syge. For så vidt angår dyr, gør der sig det særlige forhold gældende, at sygdomme kan opstå pludseligt og kan være korte og forbigående eller have længerevarende karakter.

i. Sager, hvor sælger ikke har opfyldt beviskravet

$$
\text { 8. Sag 2003-590/7-42 }
$$

\footnotetext{
Klageren havde købt en hundehvalp, som allerede dagen efter fik diarré og måtte behandles af dyrlæge. Behandlingen hjalp ikke, og klageren kontaktede derfor en ny dyrlæge, der konstaterede, at hunden led af Isospora Canis. Dyrlægen foretog derudover en operation for mulig tarmperforation, da det befrygtedes, at hunden havde slugt et fremmedlegeme. Klageren forlangte, at den erhvervsdrivende godtgjorde dyrlægeudgifterne, men den erhvervsdrivende ville alene godtgøre en mindre del. Forbrugerklagenævnet udtalte, blandt andet under henvisning til en udtalelse fra Det Veterinære Sundhedsråd, at det var sandsynligt, at hunden var smittet med Isospora Canis på leveringstidspunktet. Da den erhvervsdrivende derfor ikke havde afkræftet formodningen for, at sygdomsanlægget var til stede på leveringstidspunktet, lagde nævnet til grund, at hunden var behæftet med en mangel ved leveringen. Nævnet bestemte, at klageren var berettiget til at forholdsmæssigt afslag på kr. 2.000. Da den erhvervsdrivende ikke kendte eller burde have kendt til sygdomsanlægget ved leveringen, fik klageren derimod ikke godtgjort dyrlægeudgifterne.
}

I denne sag var hunden syg allerede dagen efter overgivelsen og igennem længere tid, idet den første behandling ikke hjalp. Det afgørende var, at det ifølge den sagkyndige erklæring var sandsynligt, at manglen forelå på leveringstidspunktet, idet den erhvervsdrivende „herefter” ikke havde afkræftet formodningen. Ræsonnementet svarer til ræsonnementet i sag 1 .

ii. Sager, hvor sælger har opfyldt beviskravet

12. Sag $590 / 7-44$ 


\begin{abstract}
Klageren havde købt en hund den 2. februar 2003. Fra den 4. februar 2003 havde hunden blod i afføringen og diarré samt øremider og øjenbetændelse. Efterfølgende konstateredes flere andre fejl. Klageren kontaktede den erhvervsdrivende, som rådede klageren til at give hunden skånekost. Samtidig mente den erhvervsdrivende, at det var dumt at tage hunden med til dyrlægen for så lille en ting. Klageren henvendte sig alligevel til en dyrlæge, som behandlede hunden. Regningen lød på kr. 2.340,62, som klageren forlangte, at den erhvervsdrivende skulle godtgøre. Klageren ønskede desuden at hæve købet. Forbrugerklagenævnet udtalte, at da hunden blev undersøgt den 5. februar 2003, blev hundens almenbefindende fundet upåfaldende, og det blev udtrykkeligt præciseret, at hunden ikke blev fundet påvirket af diarré. I følge en sagkyndig erklæring var der på denne baggrund ikke grundlag for at antage, at fejlene havde været til stede ved leveringen. Den erhvervsdrivende havde derfor afkræftet formodningen for, at fejlene var til stede ved leveringen. Klagerens krav blev derfor afvist
\end{abstract}

Det afgørende i denne sag var den sagkyndige erklæring. Indtrykket er, at sygdommen af den sagkyndige skønnes at være af korterevarende karakter, hvorfor den meget vel kan tænkes at være opstået efter overdragelsen, selv om den giver sig udslag allerede to dage efter købets indgåelse. Den sagkyndiges vurdering er på denne baggrund, at der ikke er grundlag for at antage, at manglen var til stede på leveringstidspunktet. Denne vurdering lægges til grund af Forbrugerklagenævnet.

Sammenfattende kan konstateres, at man i de danske afgørelser rent sprogligt anvender forskellige formuleringer i relation til „beviskravet”. I de to første sager vedrørende tekniske forhold (pc mv.) anvendes udtrykket „godtgøre“, mens man i alle de øvrige sager anvender udtrykket „afkræftet formodningen for”. De forskellige sproglige formuleringer synes dog ikke umiddelbart at dække over indholdsmæssige forskelle.

Også i dansk ret er de fleste sager faldet ud til forbrugerens fordel. Dette er tilfældet, når det ud fra den sagkyndige erklæring, må anses for sandsynligt, at manglen forelå på leveringstidspunktet (sag 1, (beklædningsgenstand), sag 8, (dyr), men også i tilfælde, hvor dette ifølge den sagkyndige erklæring blot ikke kan afvises (sag 6 (beklædningsgenstand)).

I tre sager fandt man, at bevisbyrden var løftet af den erhvervsdrivende. De to sager angik beklædningsgenstande, hvor der var tegn på forkert brug, og den sagkyndige erklæring støttede denne antagelse. Den tredje sag angik køb af en hund, hvor der ifølge den sagkyndige erklæring ikke var grundlag for at antage, at den pågældende sygdom - som hurtigt forsvandt igen - havde været til stede på leveringstidspunktet.

Det er et særtræk ved de danske afgørelser, at der som udgangspunkt indhentes en sagkyndig erklæring af Forbrugerklagenævnet. Erklæringen tillægges endvidere betydelig vægt ved vurderingen af sagsforholdet. 


\subsubsection{Finsk ret}

\section{Generelt}

I finsk ret følger det direkte af ordlyden af konsumentskyddslagen kap 5, $\S 15$, 2, at sælger fritages for ansvar, hvis han kan „bevise”, at varen ikke var mangelfuld på leveringstidspunktet. Af særlig interesse i relation til spørgsmålet om kravene til sælgers bevisførelse er følgende sager:

\section{Dyr og planter}

i. Sager, hvor sælger ikke har opfyldt beviskravet

\section{Sag $04 / 36 / 735$}

En forbruger købte i januar 2004 tre akvariefisk. Kort tid efter købet underrettede forbrugeren sælgeren om, at sygdommen hvid prikkesyge nu fandtes i hans akvarium. Forbrugeren påstod, at sygdommens tilstedeværelse var forårsaget af de indkøbte fisk, hvorfor han krævede erstatning for fiskedød mv. for i alt 141,50 EUR. Sælgeren afviste dette. Nævnet udtalte, under henvisning til 5 kap. 12 §o 5 kap. $15 \S$ i konsumentskyddslagen, og idet man citerede formodningsreglen, at en smitsom sygdom hos en solgt fisk kan udgøre en mangel, idet man dog måtte tage hensyn til, at der var tale om levende dyr. Nævnet fandt, at fiskene, henset til hvor hurtigt efter leveringen sygdommen viste sig, led af en mangel på leveringstidspunktet. Da sælgeren ikke havde afhjulpet eller foretaget omlevering, havde forbrugeren, idet der var tale om en væsentlig mangel, ret til at hæve købet og kræve erstatning. Erstatningen blev fastsat til 20 EUR, idet nævnet bemærkede, at forbrugeren til en vis grad havde udvist egen skyld, idet akvariet allerede inden de indkøbte fisk blev sat ud var overfyldt, havde dårlig vandkvalitet mv.

Der var ikke fremlagt sagkyndige erklæringer i sagen, der kunne støtte sælgers sag, og denne blev alene afgjort på grundlag af parternes forklaringer for nævnet. Et afgørende moment i sagen var, at sygdommen indtrådte meget kort tid efter leveringen. ${ }^{13}$

\section{ii. Sager, hvor sælger har opfyldt beviskravet}

I de følgende sager anses sælger for at have løftet sin bevisbyrde.

\section{Sag $04 / 36 / 565$}

En forbruger købte i november 2003 tre akvariefisk. Kort efter at fiskene var udsat i forbrugerens akvarium, udviste de sygdomstegn. Fiskene blev herefter behandlet mod parasitter mv. En af fiskene blev sendt til undersøgelse hos en ekspert, der senere samme måned konstaterede, at fisken led af fisketuberkulose. Spørgsmålet var herefter, om det var de tre akvariefisk, som havde indført smitten i forbrugerens akvarium, og om sælgeren, hvis dette var tilfældet, var erstatningsansvarlig herfor. Forbrugeren krævede erstatning for de sygdomsramte fisk, planter og akvariesandet til en samlet værdi af 610,50 EUR. Sælgeren havde tilbagebetalt vederlaget for fiskene til forbrugeren og erstattet forbrugerens omkostninger til

\footnotetext{
${ }^{13} \mathrm{Jf}$. herved for dansk ret sag 8, refereret ovenfor under 3.2.2.4.4.
} 
ekspertundersøgelsen og bestred i øvrigt opgørelsen af forbrugerens erstatningskrav. Under henvisning til 5 kap. 12 § og 5 kap. 15 § i konsumentskyddslagen udtalte nævnet, at en smitsom sygdom hos en solgt fisk kan udgøre en mangel, idet man dog måtte tage hensyn til, at der var tale om levende dyr. Et særligt problem var det, om de solgte fisk led af en mangel (=led af fisketuberkulose) allerede ved leveringen. Nævnet udtalte endvidere, at fiskesygdomme ofte rammer nyudsatte fisk i akvarier, fordi fiskene endnu ikke har udviklet resistens mod eksisterende bakterier i akvariet. Også stress i forbindelse med flytningen kan påvirke fiskene. Af en ekspertudtalelse fremgik, at så godt som hvert eneste akvarium indeholder fisk med smittebærere. Nævnet udtalte på denne baggrund: „Såsom ovan har konstaterats, antas ett fel i en vara ha förekommit redan vid tidspunkten för köpet, om felet visar sig inom sex månader från köpet och motsatsen inte bevisas. Det faktum att den säljande affärens övriga fiskar enligt säljarens utsago inte drabbats av tuberkulos tyder på att sjukdomen funnits latent i köparens akvarium. Med beaktande av den utredning som förts fram i ärendet och de typiska sätten för överföring av fisksjukdomar i akvarier med flera fiskarter, anser nämnden att det $\mathrm{i}$ föreliggeande fall visats med tillräcklig sannolikhet att sjukdomen inte fans hos fiskarna vid riskens övergang, altså vid köpet”. Forbrugeren fik herefter ikke medhold i sit krav.

Denne sag ligner sag 39, refereret ovenfor. Også i nærværende sag opstod sygdommen således ganske kort tid efter leveringen. At sagerne falder forskelligt ud må antages at skyldes, at der i sag 38 var fremlagt flere sagkyndige erklæringer til støtte for sælgers synspunkt.

\section{Sag 02/36/2194}

En forbruger købte i juni 2002 nogle roser af en erhvervsdrivende. Efter ca. tre uger blev roserne angrebet af meldug, som spredte sig til forbrugerens øvrige planter. Forbrugeren krævede herefter sine penge tilbage samt erstatning til indkøb af ny jord mv. Konsumentklagonämnden fandt, at meldug var en almindelig sygdom, som spredes med vinden. Under hensyntagen til at symptomerne først havde vist sig tre uger efter købet, fandt nævnet, at sælgeren havde bevist, at planterne ikke på leveringstidspunktet havde været bærere af sygdommen i latent form, hvorfor forbrugerens krav ikke kunne imødekommes.

I denne sag synes det afgørende at have været karakteren af den mangel, der var tale om, kombineret med tidspunktet for, hvornår symptomerne viste sig. Det fremgår ikke, om nævnet har anset det for udelukket, at manglen var til stede allerede på leveringstidspunktet, eller om det blot er blevet anset for mest sandsynligt, at denne først er opstået senere.

\section{Beklcedningsgenstande}

i. Sager, hvor sælger ikke har opfyldt beviskravet

I de følgende sager anses sælger ikke for at have løftet bevisbyrden (sagerne er også refereret ovenfor under 3.2.1.5) 
En forbruger købte den 4.1.2002 et par vintersko til sin datter. Efter en måned gik en af skoenes låse i stykker, hvilket den erhvervsdrivende reparerede vederlagsfrit. Et par måneder efter købet sprak skoenes overlæder. Den erhvervsdrivende sendte skoene til en skomager, som konstaterede, at skoene havde været udsat for en hård brug, og at de ikke længere kunne repareres. Forbrugeren krævede herefter enten et par nye sko eller en ophævelse af købet. Konsumentklagonämnden undersøgte skoene og fandt, at skoenes ydermateriale ikke var egnet til vinterbrug. Nævnet udtalte herefter, at eftersom skomaterialet var behæftet med fejl, anså nævnet det for klargjort, at der forelå en mangel som den erhvervsdrivende var ansvarlig for, og at manglen forelå allerede ved leveringen. Da manglen ikke kunne afhjælpes, og da omlevering ikke var mulig, havde forbrugeren ret til at hæve købet.

\section{Sag $02 / 31 / 2285$}

En forbruger købte den 30.4.2002 et par støvler. I henhold til varedeklarationen bestod støvlernes såler mv. af læder. Forbrugeren anvendte støvlerne en enkelt gang udendørs på et tidspunkt, hvor gaden var delvis fugtig. Efter en halv times brug var støvlerne meget nedslidte. Forbrugeren henvendte sig derefter til den erhvervsdrivende, som afviste klagen med den begrundelse, at der måtte være tale om en brugsfejl. Forbrugeren krævede, at købet skulle ophæves, og at hun fik erstattet rejseomkostninger. Konsumentklagonämnden undersøgte støvlerne og fandt, at de var forsynet med så tynde såler, at de alene var egnede til indendørs brug. Da forbrugeren ikke var informeret herom ved købet, forelå der en mangel. Nævnet fandt herefter, at den erhvervsdrivende skulle afhjælpe manglen ved at påsætte nye såler mv.

Som fremhævet ovenfor under 3.2.1.5 afgøres sagerne uden direkte brug af formodningsreglen, idet man anser det for bevist (af forbrugeren), at varerne var mangelfulde ved leveringen.

\section{ii. Sager, hvor sælger har opfyldt beviskravet}

\section{Køb af trøje (ikke nummereret):}

En forbruger, A, købte den 5. februar 2002 en trøje for EUR 36. Inden A begyndte at bruge trøjen, vaskede hun den. Efter vasken opdagede A, at der fandtes pletter på trøjen. A krævede herefter købet ophævet. Sælgeren, B, henviste til importørens forklaring, hvorefter trøjen skulle vaskes under iagttagelse af en række særlige foranstaltninger, hvilket A ikke havde overholdt. Konsumentklagonämnden foretog en undersøgelse af trøjen, og fandt ikke, at den led af en mangel. Pletterne var opstået i forbindelse med vasken, som B ikke var ansvarlig for. A fik derfor ikke medhold i sit krav om ophævelse, og nævnet fandt heller ikke anledning til at tillade A at anvende andre beføjelser. Det fremgår ikke af referatet, om A var blevet oplyst om de særlige foranstaltninger, som skulle iagttages i forbindelse med vasken, herunder om trøjen var påsat vaskeanvisninger mv. 
43. Køb af jakke (ikke nummereret):

En forbruger, A, købte den 14. maj 2003 en jakke for EUR 69. Da A havde brugt jakken en enkelt gang i nogle timer, vaskede hun den ved brug af et skånsomt vaskemiddel. Efter vasken opdagede A en række huller i det ene jakkeærme. Efter A's opfattelse beroede hullerne på en mangelfuld forarbejdning, hvilket sælgeren, B, nægtede. A krævede herefter, at B skulle ombytte jakken eller alternativt, at købet blev ophævet og omkostningerne forbundet med miseren skulle erstattes. B afviste A’s krav. Konsumentklagonämnden foretog en undersøgelse af jakken og fandt ikke, at der var tale om en forarbejdningsmangel. Hvis hullerne havde været til stede allerede på leveringsstidspunktet, ville disse have været synlige for køberen på dette tidspunkt. Nævnet fandt herefter, at da hullerne først var opstået efter risikoens overgang og altså ikke var forårsaget af en mangel ved jakken, var jakken ikke mangelfuld. A’s krav blev derfor afvist.

44. Køb af jakke og bukser (ikke nummereret):

En forbruger, A, købte den 13. april 2002 et par bukser for EUR 99. Han købte ved samme lejlighed en tilhørende jakke til EUR 134. Om eftermiddagen den første dag, da A havde anvendt sættet, lagde hun mærke til, at stoffet omkring knæene på buksernes yderside var begyndt at flosse. A klippede de løse tråde af for, at bukserne skulle se pænere ud. Det hjalp øjensynligt ikke. Sælgeren, B, ville ikke foretage sig noget, da bukserne efter hans opfattelse ikke led af en mangel. A krævede herefter, at bukserne skulle ombyttes eller alternativt, at købet skulle ophæves. B påstod, at der var tale om en skade, som var forårsaget af ydre påvirkning, og ikke som følge af en mangel ved bukserne. Konsumentklagonämnden undersøgte bukserne og fandt ikke, at bukserne led af en mangel. På højre bukseben var et større „,afskallet“ område. Skaden måtte anses forårsaget af en exceptionel brug (A oplyste, at hun blandt andet havde placeret en bærbar pc på skødet; bukserne var fremstillet af et sart materiale), og A's krav blev derfor afvist.

Det lægges i samtlige sager til grund, at der har været tale om uhensigtsmæssig brug fra forbrugerens side. Dette resultat nås gennem besigtigelse af beklædningsgenstandene. Det er således her, hvor der er synlige spor af forkert brug, muligt for sælgeren at løfte sin bevisbyrde uden inddragelse af sagkyndig bistand.

\subsubsection{Komparativ sammenstilling}

I samtlige retssystemer har sælgeren mulighed for at føre bevis for, at manglen ikke var til stede på leveringstidspunktet. Rent sprogligt anvendes også udtrykket „bevis“ i såvel svensk som norsk ret, mens man i dansk ret som oftest anvender udtrykket „afkræfte formodningen”. De sproglige forskelle synes dog ikke at afspejle en konsekvent forskel med hensyn til kravene til bevisets styrke. Det kan således ikke generelt konstateres, at der stilles lempeligere krav til sælgers bevisførelse efter dansk ret end efter svensk og norsk ret. Imidlertid har den erhvervsdrivende formentlig alt andet lige bedre praktiske muligheder for at løfte bevisbyrden i dansk ret, idet der her automatisk indhentes en sagkyndig erklæring 
til belysning af årsagen til manglen. Således kan det næppe udelukkes, at for eksempel den svenske sag nr. 17 (om maskinolie på en kjole) var faldet anderledes ud, dersom den var blevet afgjort efter dansk praksis under inddragelse af en sagkyndig erklæring.

Det er vanskeligt at udlede noget meget præcist om kravene til styrken af sælgerens bevis for, at manglen ikke forelå på leveringstidspunktet. Bevisbyrden anses kun for løftet i få sager. På nær de finske sager (34, 42, 43 og 44) er der ingen eksempler på, at bevisbyrden er anset for løftet, uden at der har foreligget en sagkyndig erklæring, som har støttet denne konklusion. De tilfælde, hvor bevisbyrden har været anset for løftet, vedrører tilfælde af mulig forkert brug (beklædningsgenstande og mobiltelefon), køb af brugte genstande (brugte biler) samt tilfælde af sygdom (køb af dyr og køb af planter). Tegn på forkert brug kan dog (i hvert fald i dansk ret) også ud fra en konkret vurdering føre til afvisning af sagen som bevisuegnet (sag 13a). Såvel tilfælde af forkert brug som køb og salg af brugte genstande er i lovforarbejderne også nævnt som eksempler på tilfælde, der e.o. vil kunne falde ind under uforenelighedsreglen. Dette viser den glidende overgang mellem tilfælde, hvor det lægges til grund, at der er ført bevis af sælger for, at manglen ikke forelå på leveringstidspunktet, og tilfælde, hvor anvendelsen af formodningsreglen ville fremstå som uforenelig med varens eller manglens art.

\subsubsection{Uforenelighedsbegrebet}

Det gælder i samtlige nordiske retssystemer, at formodningsreglen ikke finder anvendelse, dersom dette ville være „uforeneligt“ med salgsgenstanden eller den pågældende mangels art. Bestemmelsen yder ingen fortolkningsbidrag til forståelsen af dette udtryk. Det er således ikke klart, i hvor „absolut” en betydning dette udtryk skal forstås. Spørgsmålet er, om det - varens og/eller manglens art taget i betragtning - skal være udelukket, at manglen kan have været til stede på tidspunktet for leveringen, eller om dette blot skal fremstå som mere eller mindre usandsynligt. I den danske betænkning hedder det:

\footnotetext{
„Der gives ikke i direktivet nogen retningslinier for, i hvilke tilfælde formodningen er uforenelig med varens eller uoverensstemmelsens art, og rækkevidden af formuleringen synes noget uklar. Bortset fra helt åbenbare tilfælde, hvor den naturlige levetid for en vare er kortere end 6 måneder eller hvor den påberåbte kvalitetsafvigelse utvivlsomt skyldes forbrugerens uforsvarlige brug af salgsgenstanden, er det næppe muligt med sikkerhed at fastslå i hvilke tilfælde formodningsreglen ikke skal anvendes“. ${ }^{14}$
}

Af de norske forarbejder fremgår (i uddrag):

\footnotetext{
${ }^{14}$ Betænkning 1403/2001, p. 88-89.
} 
„For at unntak skal kunne gjøres, må formodningen være ,uforenelig‘ ‘.. med tingens eller mangelens art. Uttrykket indikerer en viss terskel for at unntaksregelen skal gjelde. Dersom det ikke gjelder en viss terskel, ville formålet med hovedregelen ikke nås. Det er selgeren som må påvise at formodningen er uforenlig med tingens eller mangelens art. Unntaksbestemmelsen legger opp til at det må foretas en mer generell vurdering ut fra tingens eller mangelens art. Dersom selgeren kan påvise at den aktuelle feilen ut fra alminnelige erfaringssetninger normalt kan tilskrives forhold som inntreffer senere enn risikoens overgang, vil det gjøre, at selgeren kan påberåbe seg unntakene. Det forhold at det ikke kan utelukkes at mangelen skyldes kjøperens forhold, kan ikke i seg selv sette formodningen til side.. $\cdots$

Unntaket for ,tingens art` vil først og fremst kunne tenkes anvendt på ting med kort holdbarhet, hvor det normale er at tingen forderves innenfor det aktuelle tidsrommet...Etter dette unntaket står ikke forhold knyttet til den konkrete kjøperens bruk av varen sentralt.....Etter departementets oppfatning kan en ikke generelt si at brukte ting omfattes av unntaket ,tingens art'...

Unntaket for „mangelens art“ vil typisk kunne tenkes å gjelde i tilfeller hvor årsaken til fejlen naturlig finnes i senere tilkomne forhold, og hvor mangelen selv, ut fra alminneleige erfaringssetninger, gir den indikasjon om dette. Dette kan være tilfellet dersom årsaken til en funktionssvikt ligger i enkeltkomponenter som normalt slites raskt.....Et annet eksempel vil være tilfeller hvor det foreligger indikasjoner om etterfølgende ytre påvirkning, for eksempel støt, slag som varen normalt ikke er ment å tåle“. ${ }^{15}$

\section{De svenske forarbejder indeholder følgende passus (i uddrag):}

„Beträffende frågan om oförelighet med varans eller felets art kan för det första sägas att en presumption om ursprungligligt fel torde vara oförenlig med varans art om felet t.ex. beror på att varans normala hållbarhetstid har passerats. ....Vidare torde en presumtion om ursprungligt fel kunna vara oförenlig med felets art om felet beror på en olyckshändelse eller därmed jämförlig händelse eller på vanvård, onormalt brukande eller något liknande forhållande på köpararens sidan,...Presumtionsregeln skall vara tillämplig på nya varor lika väl som begagnade. Det säger sig dock självt att presumtionen oftare kommer att visa sig vara oförenlig med varans eller felets art när fråga är om begagnade varor än när det gäller nya varor“. 16

\section{I de finske forarbejder anføres (i uddrag):}

„Antagandet kan vara oförenligt med varans art till eksempel då varans normala hållbarhetstid är mindre än sex månader. Det kan vara fråga om oförenlighet med felets art till eksempel om man upptäcker att felet är en följd av vanligt slitage eller att det uppståt genom ett olycksfall eller om man upptäcker att varan skadats på grund av att den hanterats på ett felaktigt sätt“. ${ }^{17}$

\footnotetext{
${ }^{15}$ Ot.prp.nr.44 (2001-2002) under bemærkningerne til § 18, p. 175.

${ }^{16}$ Prop.2001/02:134, p. 60.

${ }^{17}$ RP 89/2001, Detaljmotivering, afsnit 1.
} 
Generelt er der således blevet peget på kort holdbarhed af varen og ydre påvirkninger, herunder forkert brug, som eksempler på tilfælde, hvor der vil kunne foreligger uforenelighed. Det synes at være den overvejende opfattelse, at den omstændighed, at den pågældende vare er solgt som en brugt vare, ikke pr. definition indebærer, at der foreligger uforenelighed. Tilbøjeligheden til at antage, at der foreligger uforenelighed vil imidlertid - som anført i de svenske forarbejder - typisk være større, når der er tale om brugte genstande. Tankegangen synes at være, at der ved køb og salg af brugte genstande alt andet lige vil være en vis sandsynlighed for, at der løbende opstår fejl ved genstanden som følge af brug/slid, og at der derfor ikke altid bør opereres med en formodning for, at fejlen også forelå på leveringstidspunktet.

Der foreligger (endnu) kun et meget begrænset antal afgørelser, der reelt kan illustrere anvendelsen af reglen. ${ }^{18}$ Afgørelserne vedrører køb af brugte biler.

I den følgende svenske sag, som drejede sig om en 6 år gammel bil, blev det eksplicit overvejet, om der var grundlag for at afvise klagen på dette grundlag. Det hedder her:

\section{Sag 2003-06-03; 2002-8731}

Klageren havde købt en brugt bil for kr. 86.500 i begyndelsen af juli måned 2002. I oktober måned samme år brast kileremmen. Det kostede kr. 22.111 at reparere motorskaden. Klageren forlangte, at forhandleren skulle betale alle omkostninger forbundet med reparationen. Forhandleren nægtede dette og henviste til, at parterne havde aftalt, at omkostningerne ved reparationen skulle deles. Det allmänna reklamationsnämnden udtalte, at eftersom forhandleren ikke havde bevist, at fejlen, som under hensyntagen til bilens alder og stand måtte anses for en mangel, ikke var til stede ved leveringen, måtte manglen antages at have bestået ved leveringen medmindre dette var uforeneligt med varens eller manglens art. Nævnet udtalte herom: „I ärendet har säljeren inte presenteret någon utredning som visar att felet inte fanns vid avlämnandet. Felet skall därör anses ha funnits vid denne tidpunkt om denna presumtion inte är oförenlig med varans eller felets art. I förarbeterna till den nya bestämmelsen i 20 a § KKL anfördes i denna fråga bl.a. att det ligger i sakens natur att de fel som kan träffas av regeln är sådana som framträder efter en tids använding, främst funktionssvikter av olika slag....Nämnden konstaterer till att börja med att det i ärendet inte har visats att felet är av sådan art att det beror på något förhållande på konsumentens sida...När det härefter gäller frågan om presumtionen för ursprungligt fel är oförenlig med varans art kan konstateras att ärendet gäller en begegnad bil som vid leveransen var sex år gammal och hade gått drygt 8.000 mil. En kamrem kan i någon mån sägas vara en förbruknings/förslitningsdetalj. Emellertid kan inte med säkerhet förutses - såsom i det lagens förarbeten omnämnda exemplet med färskvaror med begränsad hållbarhet - att en kamrem nödvändigvis kommer att gå sönder inom sex månader från leveransen. Även om der är fråga om en begagnad bil har det i ärendet inte kommit fram någonting som visar att antagandet att felet fanns redan vid avlämnandet skulle vara oförenligt med varans art. Säljaren kan därför inte undgå ansvar för fe-

\footnotetext{
${ }^{18}$ I flere sager kan implicit udledes, at man ikke har fundet, at uforenelighedskriteriet kunne danne grundlag for en afvisning af formodningsreglen, da kriteriet slet ikke nævnes.
} 
let på denna grund.“ Forhandleren skulle derfor tilbagebetale de kr. 10.000 til klageren, som denne var blevet afkrævet i forbindelse med reparationens udførelse, idet nævnet bemærkede, at forhandleren ikke havde ført bevis for, at der var indgået en aftale om fordeling af omkostningerne mellem parterne.

Som nævnt i de svenske forarbejder vil der alt andet lige være større mulighed for at nå frem til, at anvendelsen af formodningsreglen er uforenelig med manglens eller varens art, når der er tale om køb af en brugt bil, end når der er tale om køb og salg af nye varer. Alligevel fastholdes $\mathrm{i}$ afgørelsen ganske strenge krav til beviset for, at der foreligger uforenelighed. Som begrundelse for at afvise dette anføres således, at det ikke med sikkerhed kan forudses, at en kamrem nødvendigvis kommer til at gå i stykker inden for 6-månedersfristen. Denne regelanvendelse, der kan siges at udgå fra et princip om, at der kræves „absolut uforenelighed”, fremstår umiddelbart som værende i overensstemmelse med udlægningen af reglen i de svenske forarbejder. ${ }^{19}$

Der findes ligeledes en norsk afgørelse vedrørende køb af en brugt bil, hvor man udtrykkeligt forholder sig til fortolkningen af udtrykket ,uforenelighed”.

\section{Sag $2004 / 03 / 70$}

Forbrugeren havde købt en brugt bil i 2003. I sin klage til Forbrukertvistutvalget anførte forbrugeren, at sælgeren ca. 3 uger efter købet påsatte vinterdæk på bilen. Efter et par ture observerede forbrugeren, at bilen ikke havde et optimalt vejgreb. Forbrugeren oplyste angiveligt sælgeren herom, men denne fandt dækkene i forskriftsmæssig stand. Forbrugeren lod herefter bilens dæk undersøge af en anden forhandler, som fandt, at mønsterdybden på tre af dækkene var under de lovbefalede $3 \mathrm{~mm}$. Da forbrugeren var afhængig af sin bil, købte han nye dæk hos denne forhandler. Ifølge forbrugeren var det aftalt med bilens sælger, at denne skulle leveres med komplette vinter-og sommerdæk. Han reklamerede skriftligt ultimo januar 2004. Bilens sælger oplyste, at bilen blev leveret med vinterdæk, og at de således ikke blev eftermonteret. Forbrukertvistutvalget fandt det mest sandsynligt, at dækkene ikke var forskriftmæssige, og dermed var mangelfulde, ved leveringen, og lagde i den forbindelse afgørende vægt på, at det var begrænset, hvor meget dækkene kunne være slidt i perioden fra leveringen til de blev undersøgt af den anden forhandler. Udvalget udtalte endvidere „for en ordens skyld”, at formodningsreglen ikke fandt anvendelse, idet dæk udsættes for slitage af en sådan art, at formodningsreglen i den foreliggende sag er uforenelig med manglens art. Forbrugeren havde imidlertid ikke krav på fuld erstatning, idet det kun var tre af dækkene, som ikke var forskriftmæssige, og da sælgeren ikke havde lovet ham helt nye vinterdæk.

Som det fremgår, opereres tilsyneladende her med et mindre absolut „uforenelighedsbegreb“. Det er tilstrækkeligt, at den pågældende vare i relativt vidt omfang udsættes for slitage.

\footnotetext{
${ }^{19}$ Afgørelsens retskildemæssige værdi betvivles ikke desto mindre i litteraturen efter de fire plenumafgørelser (sagerne 23, 25, 26 og 21, omtalt ovenfor) fra nævnet fra 2003, jf. således Johnny Herre, Konsumentköplagen, 2. udgave, 2004, p. 252 med note 129.
} 
Fra dansk ret foreligger en enkelt afgørelse. Her anlægges tilsyneladende også en noget (for sælger) mildere bedømmelse.

\section{Sag 521/7-366.}

Sagen drejede sig om køb af en 17 år gammel bil, som på købstidspunktet havde kørt 203.000 km. Prisen var 8000 kr. Ca. en måned efter leveringen, hvor bilen ifølge værkstedet skulle have kørt endnu 1259 km, opstod en fejl ved toppakningen, som måtte udskiftes. Køberen indbragte sagen for Forbrugerklagenævnet, idet han gjorde gældende, at bilen led af en mangel, og at han derfor ikke skulle betale reparationsudgifterne. Nævnet udtalte: „Bilen var efter det oplyste funktionsdygtig ved leveringen, og der kan under hensyn til bilens alder og kørte antal kilometer ikke opstilles en formodning for, at den senere opståede fejl ved toppakningen skyldes, at bilen ved leveringen var i en ringere stand, end klageren havde grund til at regne med, jf. herved købelovens $\S 76$, stk. 1, nr. 4 sammenholdt med $\S 77$, stk. 3 in fine.... Det findes som følge af det anførte ikke godtgjort, at det er med urette, at indklagede har afkrævet klageren betaling for reparationen...”. Forbrugeren fik herefter ikke medhold i sit krav.

Der synes at være to elementer i sagen, nemlig for det første spørgsmålet om hvorvidt det forhold, der nødvendiggør udskiftningen af toppakningen, overhovedet kan betegnes som en mangel ved en 17 år gammel bil og for det andet, om denne mangel i givet fald forelå på leveringstidspunktet.

Der tages ikke udtrykkeligt stilling til, om bilen overhovedet kan betegnes som mangelfuld. ${ }^{20}$ Som præmisserne er formuleret kan man få det indtryk, at selve mangelsvurderingen håndteres gennem en afvisning af anvendelsen af formodningsreglen. Dette kan imidlertid ikke være en rigtig læsning af afgørelsen. Meningen må være, at selv om man antog, at bilen er mangelfuld, er der ikke grundlag for at opstille en formodning for, at denne mangel også forelå på leveringstidspunktet. Da forbrugeren ikke har godtgjort, at dette var tilfældet, afvises klagen.

Den udtrykkelige henvisning til § 77a, stk.3 in fine indebærer, at afgørelsen under alle omstændigheder udgør et fortolkningsbidrag i relation til „uforenelighedskriteriet“. Ifølge afgørelsen er det således uforeneligt med varens og/eller den pågældende fejls art (en 17 år gammel bil og en fejl i toppakningen) at opstille en formodning for, at den pågældende fejl også forelå på leveringstidspunktet. Man synes således her at udgå fra et mindre absolut uforenelighedskriterium end i den svenske sag.

For en umiddelbar betragtning anlægges således i den danske sag en noget mildere bedømmelse (over for sælger) end i den svenske sag. Sagerne er på den anden side ikke direkte sammenlignelige, da den brugte bil i den svenske sag var 6 år gammel, mens den i den danske sag var hele 17 år gammel.

\footnotetext{
${ }^{20}$ De udskiftede reservedele var efter det oplyste kasseret og kunne derfor ikke undersøges.
} 
Udover de ovenfor beskrevne afgørelser foreligger en enkelt dansk afgørelse, hvor uforenelighedskriteriet synes at være blevet anvendt, selv om dette ikke siges direkte

2. Sag 2002-521/7-1568: køb af bil - stenslag i forrude

En forbruger, A, købte i april 2002 en bil, som blev synet efter køb. Bilen blev ikke godkendt på grund af flere sikkerhedsmæssige fejl. A reklamerede over fejlene og gjorde derudover gældende, at der var et stenslag i forruden, som ikke havde været der, da hun prøvekørte bilen. Den erhvervsdrivende, B, afviste kravene, hvorefter A indbragte sagen for Forbrugerklagenævnet. Forbrugerklagenævnet udtalte, at da et stenslag i en forrude er en typisk brugsomstændighed, og da det ikke var nævnt i synsrapporten udarbejdet efter leveringen, var der ikke grundlag for at formode, at stenslaget var til stede på leveringstidspunktet. A kunne derfor ikke fremsætte krav mod B angående stenslaget. Derimod var A berettiget til at påberåbe sig de sikkerhedsmæssige fejl som køberetlige mangler. Da den sagkyndige havde vurderet, at disse fejl forelå på leveringstidspunktet, og at det ville koste ca. kr. 9.000 at afhjælpe de konstaterede sikkerhedsmæssige mangler, fandt nævnet, at $\mathrm{A}$ var berettiget til et rimeligt afslag i købesummen, der blev fastsat til kr. 9.000. Nævnet fandt ikke, at B havde pligt til at betale A’s udgifter ved et nyt syn.

I denne afgørelse var det afgørende i relation til kravet vedrørende stenslaget i ruden således, at stenslag i en rude er en typisk brugsomstændighed. Som følge heraf anses der ikke at være grundlag for at anvende formodningsreglen. Dette kan læses sådan, at antagelsen af, at denne mangel var til stede på leveringstidspunktet ville være uforeneligt med manglens art. Alternativt kan afgørelsen læses således, at formodningen for manglens tilstedeværelse på leveringstidspunktet anses for afkræftet, jf. nærmere ovenfor under 3.2.2.4.

Sammenfattende kan det konkluderes, at praksis i relation til uforenelighedskravet, når det gælder køb og salg af brugte biler, tegner et billede af en lidt mere sælgervenlig praksis i norsk og dansk ret, end i svensk ret, hvor man udgår fra et mere absolut uforenelighedskriterium.

Ses på et andet område, nemlig området for køb og salg af mobiltelefoner, tegner der sig dog et helt andet billede. De relevante sager drejer sig her om vand- og fugtskader. I svensk ret anvendte man i den følgende sag uforenelighedskriteriet som begrundelse for at afvise køberens krav:

104. Sag 2003-06-05; 2003-0220

Klageren havde købt en mobiltelefon til kr. 3.310. Hun fik et års garanti. Det viste sig imidlertid, at telefonen ikke kunne oplades, og klageren indleverede derfor telefonen til forhandleren to dage efter købet. Forhandleren udskiftede batteriet, hvilket medførte, at telefonen nu virkede, men fortsat ikke tilfredsstillende. Ringesignalet og vibratorfunktionen virkede kun delvist. I den følgende periode udviste telefonen flere funktionssvigt, og klageren endte derfor med at indlevere telefonen til forhandleren, som sendte den til leverandøren med henblik på garantireparation. Ca. en måned efter fik klageren besked om, at telefonen var fugtskadet, og at garantien derfor ikke gjaldt. Da hun bad om at få telefonen tilbage uden reparation, fik hun at vide, at hun i så fald måtte betale kr. 370 i undersøgelsesge- 
byr. Det allmänna reklamationsnämnden udtalte, at fejlen var opstået inden for garantiperioden, og reglen i konsumentköplagens § 21 derfor var relevant. Sælgeren var derfor fri for ansvar, hvis han kunne sandsynliggøre, at fejlen skyldtes „en plyckshändelse eller därmed jämförlig händelse eller vanvård, onormalt brukande eller liknande förhållande på köparens sida“. Under henvisning til den vedlagte brugsanvisning fandt nævnet, at sælgeren havde løftet sin bevisbyrde og dermed ikke var ansvarlig for fejlfunktionen. For så vidt angik undersøgelsesgebyret udtalte nævnet i forlængelse heraf, at det ikke fremgik af sagens oplysninger, om klageren var blevet orienteret om, at der skulle betales et undersøgelsesgebyr. Var det ikke tilfældet, havde klageren ret til at få telefonen udleveret uden at betale gebyret.

I denne sag var det således afgørende, at der var gået et vist tidsrum mellem leveringen og fejlfunktionen, idet man anså det for umuligt, at mobiltelefonen skulle have været vandskadet allerede ved leveringen, når fejlfunktionen først opstod senere. Fejlens art var derfor uforenelig med anvendelsen af formodningsreglen. Til sammenligning kan fremdrages den følgende norske sag:

21. Sag $2004 / 03 / 72$

Forbrugeren købte i april 2003 en mobiltelefon. Omkring to måneder efter købet kunne telefonen ikke længere oplades. Angiveligt reklamerede forbrugeren samme dag, som problemet opstod, til forhandleren, som henviste ham til en reparatør. Reparatøren undersøgte telefonen og fandt, at den havde en fugtskade. En senere undersøgelse viste, at det ikke kunne betale sig at reparere telefonen. Efter at forbrugeren havde klaget til Forbrukertvistutvalget, tilbød forhandleren at erstatte forbrugerens omkostninger forbundet med manglen, reparatørens udgifter forbundet med undersøgelsen og fragt til reparatøren. Forbrugeren ville imidlertid også have en anden telefon. I klagen til Forbrukertvistutvalget krævede forbrugeren, at købet blev hævet, samt erstatning. Forbrukertvistutvalget lagde til grund, at der var tale om en fugtskade. Udvalget udtalte herefter, at det ikke var bevist, at fugtskaden var opstået, mens telefonen var i forbrugerens varetægt. Det tilføjedes: „Det er heller ikke påvist noe som tilsier at svikt skulle inntre straks fukt var kommet inn i telefonen, og at telefonen ikke kunne fungere i så lang tid som i denne saken, inntil skaden eventuelt utviklet seg dithen at svikten inntrådte“. Manglen måtte med andre ord anses for at have foreligget ved leveringen. Forbrugeren fik derfor ret til at hæve købet, da manglen ikke var uvæsentlig. Erstatningen blev skønsmæssigt fastsat.

I denne sag fremhæves det således udtrykkeligt, at man netop ikke anser det for udelukket, at en fugtskade først giver sig udslag på et senere tidspunkt. Uforenelighedsreglen anvendes derfor ikke. ${ }^{21}$

Spørgsmålet om hvorvidt forbrugeren har mulighed for at føre modbevis i tilfælde, hvor det antages at være uforeneligt med enten varens eller manglens art at opstille en formodning for, at manglen forelå på leveringstidspunktet, afhænger af, i hvor absolut en forstand begrebet opfattes. Opfattes det mindre absolut, er det klart, at forbrugeren har mu-

\footnotetext{
${ }^{21}$ Flere norske sager vedrørende fugtskadede mobiltelefoner er på linie hermed, se sag 31 og 33, refereret ovenfor under 3.2.1.5.
} 
lighed for at føre modbevis. Sag nr. 2, refereret ovenfor, belyser spørgsmålet. I denne sag anvendte man netop uforenelighed i en mindre absolut betydning, hvorefter det afvises, at forbrugeren har ført modbevis. Det samme var tilfældet i den norske sag 16, refereret ovenfor under 3.2.2.5.4 (dog ikke om uforenelighed).

Sammenfattende kan konkluderes, at der er i lovforarbejderne stort set er enighed om, hvilke tilfælde der kan falde ind under uforenelighedskriteriet. Der er imidlertid kun ganske få sager, der kan anvendes som fortolkningsbidrag i relation til uforenelighedskriteriet. Den foreliggende spinkle praksis kunne umiddelbart tyde på, at kriteriet fortolkes mere absolut (mindre sælgervenligt) i svensk ret end i dansk og norsk ret i relation til køb og salg af brugte biler, mens det modsatte er tilfældet i relation til fugtskadede mobiltelefoner. Da det er den erhvervsdrivende, der har bevisbyrden for, at der foreligger uforenelighed, vil der under alle omstændigheder være en glidende overgang mellem de tilfælde, hvor formodningsreglen ikke anvendes, fordi der foreligger uforenelighed, og de tilfælde, hvor reglen ikke anvendes, fordi den erhvervsdrivende anses for at have bevist, at manglen ikke forelå på leveringstidspunktet. Uforenelighedskriteriet vil ud fra en teoretisk betragtning have størst selvstændig betydning i tilfælde, hvor det kan overvejes, om varens art indebærer, at der foreligger uforenelighed. Tilfælde, hvor manglens art kan begrunde denne overvejelse, vil således ofte dreje sig om mulig forkert brug af varen, som også falder ind under den almindelige bevisregel. Jo mindre absolut uforenelighedskriteriet fortolkes, jo mere flydende vil overgangen mellem de to regler være, og jo større muligheder vil der være for, at forbrugeren kan føre modbevis.

\subsection{Komparativ sammenfatning}

På baggrund af ovenstående kan konkluderes, at hovedreglen anvendes på noget forskellig måde i de undersøgte retssystemer. Den mest „direkte“ anvendelse ses i svensk og norsk ret. I disse retssystemer anvendes reglen således uden nogen prøvelse af, om forbrugeren i øvrigt ville være i stand til at bevise eller sandsynliggøre, at manglen forelå på leveringstidspunktet. Dette gælder tilsyneladende uanset hvilken type produkt, der er tale om. Anderledes forholder det sig i dansk og finsk ret, hvor man især anvender reglen som en ekstra støtte for forbrugerens sag, hvis denne kun til dels kan bevise manglens tilstedeværelse på leveringstidspunktet (finsk ret) eller som regelgrundlag, hvis manglens tilstedeværelse på leveringstidspunktet må anses for sandsynliggjort af forbrugeren (dansk ret). Konkret sandsynliggørelse er dog ikke en betingelse for anvendelse af formodningsreglen. Denne anvendes således også i for eksempel sager om tekniske forhold, hvor en oprindelig mangel ikke kan bevises eller sandsynliggøres af forbrugeren, og der samtidig ikke er holdepunkter for 
at antage, at manglen først er opstået senere. Det er et særkende for dansk ret, at sagkyndige erklæringer i alle sager automatisk indhentes af nævnet. Det samme gælder i finsk ret i tvivlstilfælde. I svensk og norsk ret er det derimod op til sælgeren at tilvejebringe dokumentationsgrundlaget.

Det gælder i alle de undersøgte retssystemer, at sælgeren går fri for ansvar, dersom han kan bevise, at manglen ikke forelå på leveringstidspunktet. I mange sager afvises sælgers krav under henvisning til, at denne ikke har ført det fornødne bevis. I andre sager stilles tilsyneladende alene krav om, at sælger skal have „sandsynliggjort“, at fejlen først er opstået senere. Det er imidlertid vanskeligt at sige, om der reelt er forskel til kravene til „bevisets” styrke. Gennemgående er der få sager, hvor det lykkes for sælgeren at blive fritaget for ansvar. De typiske sager drejer sig om beklædningsgenstande, der har været udsat for forkert brug, og dyr, der efterfølgende har pådraget sig sygdomme. For så vidt angår tekniske forhold er det normalt svært for sælger at løfte bevisbyrden. Vedrørende mobiltelefoner findes således kun en enkelt sag, hvor sælger anses for at have løftet bevisbyrden. Normalt kræves i hvert fald, at der foreligger en sagkyndig erklæring til støtte for sælgers sag. I finsk ret findes dog et antal sager, hvor sælger fritages for ansvar til trods for, at en sådan erklæring ikke foreligger.

Der findes få sager, der vedrører uforenelighedsbegrebet. Det er især blevet anvendt i sager vedrørende køb og salg af brugte biler. I ingen af sagerne siges det dog klart, at det er uforeneligt med anvendelsen af formodningsreglen, at der er tale om brugte varer. Sagerne drejer sig primært om, hvorvidt manglens karakter indebærer, at der foreligger uforenelighed. To sager angående mobiltelefoner vedrører spørgsmålet, om den omstændighed, at henholdsvis fugt- og vandskade først opstår længere tid efter leveringstidspunktet, indebærer, at manglens art må anses for uforenelig med anvendelsen af formodningsreglen. Dette besvares for så vidt angår vandskaden bekræftende (svensk ret) og for så vidt angår fugtskaden benægtende (norsk ret). Uforenelighedsbegrebet anvendes overvejende i mindre absolut forstand. Dette indebærer, at der er en glidende overgang mellem „uforenelighedstilfælde“ og tilfælde, hvor sælger anses for at have ført bevis for for eksempel forkert brug af et produkt.

\subsection{Kendskab til og praktisering af reglerne i branchen}

I undersøgelsen „Nye regler om forbrugerkøb - en empirisk undersøgelse“, CBS, april 2005, er det søgt belyst, i hvilket omfang formodningsreglen har påvirket adfærden i detailleddet. ${ }^{22}$ Analysen blev foretaget i september 2003 på baggrund af 291 indkomne (brugbare) svar på en spørgeskemaundersøgelse i detailhandlen. I spørgeskemaundersøgelsen stillede man den erhvervsdrivende spørgsmålet:

\footnotetext{
${ }^{22}$ Se undersøgelsen p. 21-25.
} 
„Når De afgør, om De skal give en kunde, der klager, ret, skelner De da mellem, om en vare er købt inden for de sidste 6 måneder eller ej?“

Samlet set svarede mere end en tredjedel af respondenterne, at de oftere gav kunden ret inden for 6-måneders perioden end udenfor denne, mens to tredjedel svarede, at de ikke foretog nogen sondring. Adfærden varierer meget fra branche til branche. Således svarede hele 85,7 \% at de oftere gav kunden ret inden for 6-måneders fristen, mens det samme svar kun blev givet af 9,4 \% i møbelbranchen. Af øvrige brancher, hvor der blev svaret, at man oftere gav forbrugeren ret inden for 6-måneders fristen, kan fremhæves computer og software branchen (29,2 \%), dame- og herretøj (43,8 \%) og sko (36,7 \%). I undersøgelsen antages, at disse forskelle i hvert fald til dels kan forklares med, at det inden for visse brancher under alle omstændigheder ikke volder de store problemer at bedømme ud fra varens beskaffenhed og/eller tidspunktet for reklamationen, om en mangel har været til stede på leveringstidspunktet eller ej. Når dette er tilfældet, får formodningsreglen mindre praktisk betydning. I undersøgelsen konkluderes: „Sammenfattende synes formodningsreglen at have fået større betydning i praksis end tilsigtet og forventet“.

Konklusionen i CBS-undersøgelsen kan sammenholdes med en undersøgelse foretaget af Vilstrup, foråret 2004 på baggrund af interviews med 250 ansatte i detailhandlen og 500 forbrugere. Undersøgelsen er beskrevet i „Forbrugerredegørelse 2004“, udgivet af Forbrugerstyrelsen. Undersøgelsen viser, at $20 \%$ af de adspurgte ville afvise en reklamation, der finder sted senere end 6 måneder efter købet. Dette gøres med forskellige begrundelser. $1 \%$ tilkendegiver, at der blot er tale om en generel politik, $20 \%$ svarer, at det efter et halvt år ikke længere er butikkens ansvar og $15 \%$ begrunder deres afvisning med, at dette følger af købeloven. Endelig svarer $11 \%$, at „chefen har sagt det“, mens hele $48 \%$ svarer, at begrundelsen for afvisningen er ,,andet“. I redegørelsen konkluderes (p. 49), at tallene peger på, ,,at der er en stor og generel mangel på viden om [reklamationsfristen og] formodningsreglen“. Undersøgelsen søger også at belyse forbrugernes kendskab til formodningsreglen. Undersøgelsen viser, at $24 \%$ af de adspurgte rigtigt svarede, at man inden for de første 6 måneder efter købet automatisk formoder, at en konstateret fejl ved varen også var til stede på leveringstidspunktet, mens 40 \% af forbrugerne svarede „ved ikke“ til spørgsmålet. Redegørelsen konkluderer, at „indførelsen af formodningsreglen ikke helt [har] vundet indpas hos forbrugeren”.

Som det fremgår, synes fortolkningerne af de to undersøgelser ikke umiddelbart at kunne forenes. 


\title{
4. Reklamationsfristen
}

\section{1. Implementeringen og reklamationsreglerne i de forskellige retssystemer}

Direktivets artikel 5, stk. 1, indeholder en almindelig 2-årig reklamationsfrist. Reglen lyder således:

\begin{abstract}
„Sælgeren er ansvarlig i medfør af artikel 3, når den manglende overensstemmelse viser sig senest to år efter leveringen af varen. Hvis de i artikel 3, stk. 2, nævnte rettigheder ifølge national lovgivning er underkastet en reklamationsfrist, må denne ikke udløbe inden for en periode af to år fra varens levering“
\end{abstract}

Direktivets 2-års frist nødvendiggjorde ændringer i den danske og den islandske købelov, hvor der gjaldt en 1-års frist, mens man i Norge og Sverige allerede opererede med (som minimum) en 2-års frist. I disse lande havde direktivets reklamationsregel derfor ingen betydning. Fra 1. april 2005 er 2-årsfristen i forbrugerkøb i svensk ret ændret til en 3årsfrist. Også for Finland var direktivets regel uden betydning, idet man her ikke har nogen absolut reklamationsfrist.

De nordiske reklamationsregler har følgende indhold:

I dansk ret findes reglen i købelovens § 83, stk. 1:

„Har køberen ikke inden to år efter salgsgenstandens overgivelse til ham meddelt sælgeren, at han vil påberåbe sig en mangel, kan han ikke senere gøre den gældende, medmindre sælgeren har påtaget sig at indestå for genstanden i længere tid eller har handlet i strid med almindelig hæderlighed“

I islandsk ret findes reglen i lov om forbrugerkøb § 27, stk. 2:

\begin{abstract}
„Reklamerer forbrugeren ikke inden to år efter den dag da han overtog salgsgenstanden kan han ikke senere gøre mangelen gældende. Når holdbarheden af genstanden eller dele af den er beregnet at være væsentlig længere end generelt om salgsgenstande, er fristen for at reklamere fem år fra den dag genstanden blev overtaget. Dette gælder dog ikke hvis sælgeren har i garantierklæring eller anden aftale påtaget sig ansvar for mangelen i et længere tidsrum. Fristen ifølge dette stykkes $\mathrm{nr} .1$ og 2 finder dog ikke anvendelse, hvis der er tale om mangel ifølge $\S$ 15, stk. 2, litra $\mathrm{g}^{23 \text { “ }}$
\end{abstract}

\footnotetext{
${ }^{23}$ Bestemmelsen henviser til reglerne om vanhjemmel.
} 
I norsk ret findes reglen i lov om forbrukerkjøp § 27, stk. 2:

„Reklamasjon må senest skje to år etter at forbrukeren overtok tingen. Dersom
tingen eller deler av den ved vanlig bruk er ment å vare vesentlig lengre, er fristen
for å reklamere fem år. Dette gjelder ikke så langt selgeren ved garanti eller annen
avtale har påtatt seg ansvar for mangler i lengre tid. Fristene etter første og annet
punktum gjelder heller ikke dersom det foreligger en mangel etter § 15 annet ledd
bokstav g ${ }^{24 ،}$

I svensk ret findes reglen i konsumentköplagen $\S 23$, stk. $3^{25}$

„Reklamerar köparen inte inom tre år från det att han har tagit emot varan, förlorar han rätten att åberopa felet, om inte annat följer av en garanti eller liknande utfästelse tillnär § 24. Utan hinder av $23 \S$ får köparen åberopa att varan är felaktig, om säljaren har handlet grovt vårdslöst eller i strid mot tro och heder eller om felet är sådant som avses i 18 §“

Finland

Ingen reklamationsfrist

\subsection{Problemstillinger}

Selv om der i de nordiske lande gælder reklamationsregler af forskellig længde, opstår i alle retssystemer det spørgsmål, om indførelsen af formodningsreglen som gældende for de første seks måneder har nogen indflydelse på bevisbyrdeforholdene efter seksmåneders fristens udløb. Et grundlæggende spørgsmål er således, om der kan sluttes modsætningsvis fra seksmåneders reglen, sådan at det efter udløbet af seksmåneders perioden altid er forbrugeren, der har bevisbyrden. I de danske forarbejder ${ }^{26}$ gøres det klart, at en sådan modsætningsslutning ikke er intentionen med seksmåneders reglen. Hensigten har således ikke været at regulere bevisbyrdeforholdene uden for seksmåneders perioden men derimod, at almindelige bevisbyrderegler skulle gælde fra seksmåneders dagen og frem til udløbet af reklamationsperioden. Retspraksis om dette forhold søges belyst nedenfor under 3.

En anden grundlæggende problematik er spørgsmål om samspillet mellem eventuelle særlige regler om reklamationsfristens længde i forholdet mellem forbrugeren og sælgeren og eventuelle andre reklamationsfrister i forholdet mellem sælgeren og producenten. Denne problemstilling søges belyst nedenfor under 4 .

\footnotetext{
${ }^{24}$ Bestemmelsen henviser til reglerne om vanhjemmel.

${ }^{25}$ Som ændret ved Lag 2005:62.

${ }^{26}$ Betænkning 1403/2001, p. 90.
} 


\title{
4.3 Bevisbyrde og krav til bevisstyrke efter 6-måneders fristen
}

\subsubsection{Dansk ret}

I de danske forarbejder til de nye bestemmelser i købeloven anføres, at bevisforholdene og bevisbyrdeforholdene efter udløbet af seksmåneders fristen forbliver uændrede. Dette indebærer, at det efter udløbet af 6måneders fristen som udgangspunkt er forbrugeren, der har bevisbyrden for, at en påvist kvalitetsafvigelse var til stede på leveringstidspunktet. Kravene til styrken af beviset er dog ifølge forarbejderne begrænsede. Det hedder således i betænkningen:

\begin{abstract}
„Efter omstændighederne stilles der imidlertid i praksis kun begrænsede krav til forbrugerens bevisførelse. Opstår der inden for en vis kortere periode efter leveringen en fejl ved varen, som ikke er forventelig, og som ikke er et typisk udslag af uhensigtsmæssig brugspåvirkning, vil man således ofte finde, at det fornødne bevis er ført. Vurderingen heraf vil imidlertid altid ske på baggrund af de konkrete omstændigheder, herunder bl.a. om der er tale om køb af nye eller brugte genstande. “27
\end{abstract}

Er der givet garanti for det pågældende forhold, antages det, at bevisbyrden vendes således, at sælger må godtgøre, at den pågældende fejl ved varen ikke var til stede ved overgivelsen. ${ }^{28}$

I dansk praksis spiller anvendelsen af sagkyndige erklæringer også på dette område en væsentlig rolle ved bedømmelsen. Dette fremgår af de nedenfor refererede sager.

I de følgende sager talte den sagkyndige erklæring med relativ stor klarhed til forbrugerens fordel.

50. Sag 4031/7-758

En forbruger, A, købte i januar 2002 en multifunktionsmaskine (printer, kopi og scanner). I maj 2003 henvendte A sig til sælgeren, B, for at reklamere over scannerfejl og manglende kopieringsevne. B bad A om at ringe til producenten, $\mathrm{C}$, for at få telefonisk assistance til at klare fejlene. Dette hjalp imidlertid ikke, og A henvendte sig derfor atter til B. I de følgende måneder foretog B en række afhjælpningsforsøg, som kun delvist afhjalp problemerne. I september 2003 henvendte A sig atter til B, men B oplyste nu, at produktet ikke længere var dækket af garanti, og at reklamationsretten ikke dækkede fejlene, da de først var opstået mere end 6 måneder efter købet. B tilbød i stedet $\mathrm{A}$ ombytning med en brugt printer mod betaling af kr. 1.000, hvilket A afslog. A indbragte sagen for Forbrugerklagenævnet med krav om ophævelse. B afviste dette, da det ikke var bevist, at fejlene var til stede ved leveringen. I den af forbrugerklagenævnet indhentede sagkyndige erklæring udtaltes: „Det kan ikke klarlægges med sikkerhed, hvorvidt fejlen kan henføres til forhold fra klagers side eller skyldes de under spørgsmål 2a anfør-

\footnotetext{
${ }^{27}$ Betænkning 1403 (2001), p. 86-87.

${ }^{28}$ Dahl og Møgelvang - Hansen, Garantier, 1985, p. 55 ff, Betænkning 1403/2001, p. 87 ff., samt nedenfor under 4.3 .3 om svensk ret.
} 
te forhold [materiale- eller fabrikationsfejl].Det skønnes dog mest sandsynligt, at fejlen kan henføres til et af de under spørgsmål 2a anførte forhold, idet der ikke ved undersøgelse af produktet har kunnet konstateres synlige fysiske beskadigelser, samt at der ikke ved kontakten med producentens hotline har kunnet klarlægges, på hvilken måde klageren ved almindelig brug (i modsætning til intensiv brug) skulle kunne tilføre produktet en beskadigelse som den foreliggende“. Forbrugerklagenævnet fandt på den baggrund, at det var mest sandsynligt, at fejlene kunne henføres til fabrikations-og/eller materialefejl. Der var derfor tale om en oprindelig fejl, hvorfor maskinen led af en mangel, og da den ikke var afhjulpet inden rimelig tid, havde A ret til at hæve købet.

I denne sag var indholdet af den sagkyndige erklæring, at årsagen til fejlen ikke kunne afklares med sikkerhed, men at det dog måtte anses for mest sandsynligt, at der var tale om en oprindelig mangel. Forbrugeren fik på den baggrund medhold.

47. Sag 4031/7-1024

En forbruger, A, købte i april 2002 en pc. Efter 22 måneder ville den kun starte op, men ikke vise noget skærmbillede. A reklamerede derfor til sælgeren, B, som efter undersøgelse af pc'en oplyste A om, at bundkortet skulle udskiftes. B afviste A's reklamation med den begrundelse, at der var tale om slitage og ikke en mangel. A indbragte sagen for Forbrugerklagenævnet med krav om ophævelse af købet. I den af forbrugerklagenævnet indhentede sagkyndige erklæring udtaltes, at der ikke var korrekt spænding i systemkortet, og at der ikke var tegn på uhensigtsmæssig brugspåvirkning fra forbrugerens side, hvorfor den sagkyndige anså det for „overvejende sandsynligt, at computeren er behæftet med en oprindelig mangel“. Forbrugerklagenævnet udtalte, at et bundkort skal kunne holde til almindelig brugspåvirkning i mere end to år. Det fandtes derfor - under henvisning til den sagkyndiges erklæring - overvejende sandsynligt, at pc'en var behæftet med en oprindelig mangel ${ }^{29}$. Da B ikke havde foretaget afhjælpning inden rimelig tid, havde A ret til at ophæve købet.

Udover indholdet af den sagkyndige erklæring, hvorefter det var „overvejende sandsynligt“, at der var tale om en oprindelig mangel, fremhæves i afgørelsens præmisser, at et bundkort efter nævnets opfattelse skal kunne holde til almindelig brugspåvirkning i mere end to år. ${ }^{30}$

Sagen må sammenholdes med den følgende meget lignende sag, hvor den sagkyndige erklæring talte mod forbrugeren.

46. Sag $4031 / 7-1053$

En forbruger, A, købte i september 2002 en pc. Ca. 15 måneder efter købet konstaterede A, at pc'en begyndte at fryse for efterfølgende at fremstå med sort skærm. A reklamerede til sælgeren, B, som afviste reklamationen med henvisning til, at bundkortet måtte være gået i stykker som følge af „elektriske udladninger ved tilslutning af andre ydre enheder, udladninger fra lyn eller utilstrækkelig ven-

\footnotetext{
${ }^{29}$ I nævnspraksis anvendes normalt ikke formuleringen, at det må anses for overvejende sandsynligt, at der er tale om en mangel.

${ }^{30}$ Om samme tankegang vedrørende holdbarhed i relation den norske 5-årige reklamationsregel, se nedenfor under 4.3.2.
} 
tilation“ A indbragte sagen for Forbrugerklagenævnet med krav om afhjælpning, omlevering eller ophævelse. B afviste dette. Det var ikke muligt at skille bundkortet ad og foretage en sagkyndig vurdering af dette, men nævnets faste edbsagkyndige udtalte, at det ikke var sandsynligt, at defekten skyldtes egenskaber ved pc'en, som havde været til stede ved leveringen, men i stedet måtte antages at skyldes for eksempel udladninger fra lyn eller utilstrækkelig ventilation. På den baggrund fandt Forbrugerklagenævnet ikke, at det var godtgjort, at der var tale om en oprindelig mangel. A fik derfor ikke medhold i sine krav.

Ses nærmere på de to ovenfor refererede sager (sag 47 og 46), er det ikke helt klart, hvad det er, der gør, at den sagkyndige når til forskellige konklusioner i de to tilfælde. I begge sager var det således klart, at bundkortet var defekt og i ingen af sagerne kunne konstateres tegn på uhensigtsmæssig brug. Det må antages at have spillet en rolle, at det i sag 47 var muligt at konstatere, at defekten nærmere bestod i, at der ikke var korrekt spænding i bundkortet, mens dette ikke var klarlagt i sag 46. De to sager viser under alle omstændigheder, at det er meget afgørende hvilken vurdering den sagkyndige anlægger.

Det interessante spørgsmål er herefter, hvordan der forholdes, dersom den sagkyndige erklæring ikke klart peger i retning af enten den ene eller den anden forklaring på defekten. En række sager er illustrative for denne problematik.

Er der det mindste tegn på uhensigtsmæssig brug, afvises forbrugerens krav, selv om der i øvrigt på basis af den eller de sagkyndige erklæringer er tvivl om årsagen til fejlen.

50a Sag 620/7-174

En forbruger havde i december 2002 købt et par støvler. Hælen knækkede d. 2. maj 2003, og forbrugeren reklamerede i slutningen af august 2003. Der var afgivet to modstridende sagkyndige erklæringer, idet den ene konkluderede, at der ikke var tegn på uhensigtsmæssig brug, og at det var overvejende sandsynligt, at der var tale om en fabrikationsfejl, idet der var konstateret en urenhed i materialet, mens den anden konkluderede, at urenheden i materialet var uden betydning, idet styrken lå i røret, der løb midt i hælen, hvorfor skaden med overvejende sandsynlighed måtte antages at skyldes uhensigtsmæssig brugspåvirkning. Forbrugerklagenævnet fandt under henvisning til den anden erklæring samt under henvisning til, at der kunne konstateres en ridse i hælen, og at høje hæle generelt er sårbare over for ydre påvirkninger, at det var mest sandsynligt, at der var tale om en skade, der var opstået under uhensigtsmæssig brugspåvirkning. Forbrugeren fik derfor ikke medhold i sit krav.

Også i den følgende sag afviste man forbrugerens krav.

48. Sag 4051/7-551

En forbruger, A, købte i februar 2002 en trådløs telefon. Ca. 23 måneder efter henvendte A sig til sælgeren, B, og klagede over, at håndsættet ikke kunne lade, og at der ikke var forbindelse til basen. B solgte et nyt sæt batterier til A, men dette hjalp ikke. B tilbød herefter at sende telefonen videre til undersøgelse, men A 
indbragte sagen for Forbrugerklagenævnet med påstand om ophævelse, da der ikke var sket afhjælpning inden rimelig tid. B afviste dette og henviste til, at den manglende funktion skyldtes, at A havde „sjat-ladet“ batterierne. Ifølge den af nævnet indhentede sagkyndige erklæring skyldtes problemet enten, at batterierne var defekte, eller at disse var blevet ødelagt ved „sjat-ladning“. Den sagkyndige oplyste endvidere, at batterier af den pågældende type typisk kan holde til 1000 opladninger svarende til én opladning i døgnet i 2,7 år. Da der således var tale om batterier, hvis levetid afhang af anvendelsesforholdene, og da de pågældende batterier havde holdt i 23 måneder, fandt nævnet det ikke godtgjort, at disse havde været mangelfulde ved leveringen. Da der heller ikke i øvrigt var påvist mangler ved telefonen, fik forbrugeren ikke med hold i sit krav.

I denne sag var der ikke konkrete holdepunkter for, at der ikke havde været tale om fejlanvendelse („sjat-ladning“) fra forbrugerens side. Tværtimod fremgår det af sagens akter, at batteriladning ville forekomme hver gang telefonen blev placeret i holderen, hvilket der ifølge sælgeren var advaret mod i brugsanvisningen. ${ }^{31}$ Samlet set kunne man derfor ikke anse det for godtgjort, at der var tale om oprindelige mangler ved batterierne.

En „åben“ erklæring fra den sagkyndige kan også føre til, at sagen afvises fra nævnet som bevisuegnet.

50c Sag 403/7-730

Forbrugeren købte den 18. december 2002 en computer og reklamerede over denne den 18. juni, idet computeren „frøs“. Der var knækket et stykke af USB-porten. Producenten erkendte ifølge forbrugeren, at der var en generel komponentfejl ved modellen, som medførte striber på skærmen, forstyrret video, og at pc’en „frøs“. Forbrugeren anførte først den 14. juli 2002, at pc’en også havde de øvrige af producenten nævnte symptomer. Af den sagkyndige erklæring fremgik ifølge nævnets afgørelse, at „det ikke kan udelukkes, at den af klageren påførte beskadigelse har medført den konstaterede fejl på pc’en, om end det skønnes mindre sandsynligt, at dette alene har været årsagen“. Det fremgik endvidere, at den af producenten nævnte generelle komponentfejl ikke med sikkerhed kunne påvises på forbrugerens computer. På den baggrund fandt nævnet det ikke muligt at træffe afgørelse uden en yderligere bevisførelse, som lå uden for rammerne af Forbrugerklagenævnets kompetence. Sagen afvistes derfor. ${ }^{32}$

Selv om det fremgår af erklæringen, at der ikke er holdepunkter for at antage, at der har været tale om uhensigtsmæssig brug, er et ikke givet, at forbrugeren får medhold, hvis erklæringen i øvrigt ikke peger på én årsag som mere sandsynlig end en anden. I den følgende sag, hvor der blev reklameret efter 15 måneder, afviste man således enstemmigt forbrugerens krav, selv om der ifølge den sagkyndige erklæring ikke var tegn på uhensigtsmæssig brug.

\footnotetext{
${ }^{31}$ Det fremgår ikke af sagen, om det har været overvejet, om et ansvar for sælgeren kunne have været baseret på tilsidesættelse af den loyale oplysningspligt ved manglende mundtlig oplysning om dette forhold.

${ }^{32}$ Se også sag 4031/7-609.
} 
50b Sag 4031/7-878

Forbrugeren købte i maj 2002 en computer og efter ca. 15 måneder reklamerede forbrugeren over, at skærmen var gået i sort. I følge den sagkyndige erklæring kunne konstateres diverse fejl, som formentlig skyldtes ,ustabilt fungerende komponent/-er og/eller stikforbindelser i forbindelse med systemkortets integrerede grafikkort“. Der var ingen ydre tegn på fald, slag eller anden overlast. Da det ikke fremgik af den sagkyndige erklæring, om det konstaterede kunne henføres til computerens beskaffenhed på leveringstidspunktet, og da denne havde fungeret upåklageligt de første 15 måneder, fandt Forbrugerklagenævnet ikke grundlag for at antage, at der var tale om en oprindelig mangel.

Sagen bør sammenholdes med den følgende sag, hvor de konkrete omstændigheder i følge den sagkyndige også tydede på, at der ikke havde været tale om uhensigtsmæssig brug.

49. Sag 4012/7-321

En forbruger, A, købte i december 2002 et tv. I tre tilfælde, henholdsvis to gange i juli 2003 og én gang i august 2003, reklamerede A over dels en hylelyd, dels fejl i billedrøret, som gav sig udslag i røde og grønne striber over skærmen. B påstod, at A selv havde forårsaget fejlene ved at have tabt TV'et. A indbragte sagen for Forbrugerklagenævnet med krav om ophævelse, afhjælpning eller omlevering og afviste selv at have forårsaget fejlene.

Forbrugerklagenævnet lagde på baggrund af den af nævnet indhentede sagkyndige erklæring til grund, at hyletonen skyldtes en oprindelig mangel ved TV'et. For så vidt angik billedrøret havde den sagkyndige udtalt, at dette ikke var en ofte forekommende fabrikationsfejl, og at det i den konkrete sag ikke var muligt at sige, hvornår fejlen var opstået. Samtidig vurderedes, at det ikke kunne udelukkes, at fejlen var opstået ved at TV'et var blevet udsat for stød, men at der i så fald sædvanligvis også ville være ske skade på kabinettet (hvilket ikke var tilfældet). Et flertal i nævnet fandt på denne baggrund, at forbrugeren havde bevist, at fejlene beroede på fabrikations- og/eller materialefejl, som havde været til stede ved leveringen. Mindretallet fandt, at da den sagkyndige ikke med sikkerhed havde været i stand til at fastslå, om fejlen havde været til stede ved leveringen, havde A ikke løftet sin bevisbyrde. Der blev truffet afgørelse efter flertallets opfattelse, således at A havde ret til at hæve købet, idet fejlene alt i alt måtte anses for en væsentlig mangel.

I denne sag var det heller ikke muligt for den sagkyndige at sige med sikkerhed, om fejlen var opstået før eller efter leveringstidspunktet. Fejlen var ikke en typisk fabrikationsfejl, men de konkrete forhold pegede i retning af, at der ikke havde været tale om uhensigtsmæssig brug fra forbrugerens side. På denne baggrund anså et flertal i nævnet det for bevist, at der var tale om en oprindelig mangel, mens et mindretal nåede til den modsatte konklusion. Flertallets vurdering i sagen kan have sammenhæng med, at der reklameres allerede 7 måneder efter overgivelsen (mod 15 måneder i sag 50b, refereret ovenfor). 
Sammenfattende kan konkluderes, at man i dansk retspraksis efter indførelsen af 6-måneders formodningsreglen i købeloven uden for denne frist fastholder princippet om, at det er forbrugeren, der har bevisbyrden for, at en påvist fejl ved varen også var til stede på leveringstidspunktet og dermed udgør en mangel. Indholdet af den af forbrugerklagenævnet indhentede sagkyndige erklæring spiller i denne sammenhæng en væsentlig rolle. Der er ikke eksempler på, at man har tilsidesat den sagkyndige erklæring og anset bevisbyrden for løftet i tilfælde, hvor den sagkyndige erklæring går forbrugeren imod. Omvendt får forbrugeren medhold, dersom den sagkyndige erklæring er til dennes fordel. Det kræves ikke, at den sagkyndige erklæring med sikkerhed udpeger årsagen til at være en oprindelig mangel. Det er tilstrækkeligt, at dette ifølge den sagkyndige erklæring må anses for „mest sandsynligt“ (sag 50) eller overvejende sandsynligt (sag 47). Er indholdet af den sagkyndige erklæring, at det ikke kan klarlægges, hvad der er den mest sandsynlige årsag til en defekt, (sag 48) er det udgangspunktet, at bevisbyrden ikke er løftet. Er der det mindste tegn på forkert brug, afvises forbrugerens krav, eller sagen afvises fra nævnet som bevisuegnet (sag 50a, 48 og 50c). Men selv om det fremgår af den sagkyndige erklæring, at der ikke er holdepunkter for at antage, at der har været tale om uhensigtsmæssig brug, er dette ikke nødvendigvis tilstrækkeligt til, at bevisbyrden anses for løftet (50b). Kravene til forbrugerens bevisførelse synes en anelse lempede, hvis der er reklameret kort tid efter udløbet af formodningsreglen i den forstand, at det $\mathrm{i}$ så fald lægges til grund, at der er tale om en oprindelig mangel, hvis der er konkrete holdepunkter for at udelukke, at der har været tale om uhensigtsmæssigt brug fra forbrugerens side eller andre udefra kommende påvirkningsfaktorer (sag 49). Alt i alt synes der således - i modsætning til, hvad man i lovforarbejderne forventede, jf. ovenfor - at være tale om temmelig strenge krav til forbrugerens bevisbyrde efter udløbet af 6 måneders fristen.

\subsubsection{Norsk ret}

Dersom tingen ved vanlig brug er beregnet til at holde i længere tid end 2 år gælder som ovenfor beskrevet en særlig 5-årig reklamationsregel. Der har været rejst spørgsmål om, hvorvidt der for køb omfattet af denne regel skulle gælde en særlig formodningsregel til fordel for forbrugeren, hvorefter en mangel ved varen, der opstår inden udløbet af 5-årsfristen, skal formodes at have været til stede på tidspunktet for risikoens overgang (leveringstidspunktet). Tanken har støtte i en mindretalsudtalelse afgivet fra Stortingets justitskomite i forbindelse med vedtagelsen af 5årsreglen i den tidligere § 32, stk. 3 i kjøpsloven. Udtalelsen lød: 
mangel i løpet av en fem-års frist, indikerer dette imidlertid at gjenstanden i seg selv var mangelfull da risikoen gikk over. En mangelfri gjenstand skulle nemlig vare vesentlig lengre. Hvis manglen viser seg mens gjenstanden har vært i normal bruk, er det altså en sterk presumsjon for at mangel forelå ved risikoens overgang“ 33

Udtalelsen synes altså for visse typer af varer (nemlig sådanne, der er beregnet til at have en holdbarhed på mere end 2 år) at lægge op til en mulig anerkendelse af en formodningsregel svarende til den senere i direktivet lovfæstede formodningsregel, blot udstrakt til en 5-årsperiode. Spørgsmålet om eksistensen af en sådan formodningsregel blev behandlet af Høyesterett i sagen

Rt 1998.774.

\section{Sag Rt 1998.774}

Denne sag drejede sig om fejl i en videomaskine, som opstod efter tre et halvt års brug. Det lagdes til grund, at der var tale om en vare, som ved vanlig brug var beregnet til at kunne holde i væsentlig længere tid end to år. 5-års reklamationsfristen fandt derfor anvendelse. Spørgsmålet var, om forbrugeren måtte godtgøre, at manglen havde været til stede ved leveringstidspunktet, eller om der gjaldt en særlig formodning herfor. Til støtte for det sidste henviste forbrugeren til Stortingsudtalelsen citeret ovenfor. Høyesteret anførte imidlertid følgende om udtalelsen: „Uttalelsen er etter min mening ikke entydig. Den kan iallfall forstås enten slik at den uttrykker en særlig bevisbyrderegel til fordel for forbrukerkjøpere, eller slik at den uttrykker en alminnelig erfaringssetning om faktiske forhold som må tillegges betydning ved bevisbedømmelsen. Jeg finner det for min del mest nærliggende å forstå uttalelsen på den sidstnevnte måten“. Det afgørende i sagen var efter Høyesteretts opfattelse, at den erhvervsdrivende ikke havde „funnet det formålstjenlig å undersøke IR-mottakeren for eventuelt å klarlegge årsaken til funktionssvikten.“ Sælgeren fandtes herved at have tilsidesat sin „,bevisføringspligt“, hvilket måtte belaste sælgeren. Høyesterett fandt det på den baggrund godtgjort, at videomaskinen havde en svaghed ved leveringen, som ledte til svigtet tre et halvt år senere. Da svagheden endvidere måtte karakteriseres som en mangel, fik forbrugeren medhold i sit krav.

Som det fremgår, afviser Høyesterett, at der skulle gælde en særlig 5-års formodningsregel i forbrugerkøb. Efter afgørelsen er dette også blevet den almindelige opfattelse. Dette udtrykkes i forarbejderne til den nye Forbrukeraftalelov ${ }^{34}$ og i litteraturen. ${ }^{35}$ Udgangspunktet er herefter, at forbrugeren har bevisbyrden for, at en fejl ved produktet var til stede på leveringstidspunktet og dermed udgør en mangel. Som det fremgår af dommen, har sælgeren imidlertid en „bevisføringspligt“. Heri ligger, at det under en samlet bevisvurdering vil komme sælgeren til skade, hvis han, der sidder inde med den tekniske viden og de økonomiske ressourcer, ikke

\footnotetext{
${ }^{33}$ Innst. O. nr. 51 (1987-88), p. 13.

${ }^{34}$ Ot.prp.nr. 44 (2001-2002), p. 94

${ }^{35}$ Selvig, Kjøpsrett til studiebruk, 2. udg., 2004, p. 227 ff, Hagstrøm, Kjøpsrett, 2005, p. 89 med note 191.
} 
har forsøgt at få klarlagt, hvad der er årsagen til varens funktionssvigt. ${ }^{36}$ Resultatet af denne regel er en betydelig lempelse af forbrugerens bevisbyrde.

Hvordan reglen fastslået af Høyesterett nærmere er blevet forstået i Forbrukertvistutvalgets praksis fremgår af de følgende sager:

$$
\text { 54. Sak } 2004 / 256
$$

Klageren havde købt en Sony Playstation 2 for kr. 2.685 den 2. november 2001. Den 1. marts 2004 ophørte maskinen med at fungere, idet den ikke længere ville læse Playstation 2-spil. Klageren reklamerede derfor til forhandleren, som den 5. marts 2004, uden at have foretaget nogen undersøgelse af maskinen, antog, at problemet skyldtes en fejl på laseren. Klageren var enig i, at problemet højst sandsynligt skyldtes en fejl på laseren, men ønskede ikke at betale de kr. 400, som det ville koste at undersøge maskinen. Forbrukertvistutvalget fandt, at en Playstation 2 har en forventet levetid på mere end to år ved sædvanlig brug. Maskinen omfattedes derfor af den absolutte femårige reklamationsfrist. Herefter udtalte udvalget: „Ifølge Høyesteretts dom i Rt. 1998 s. 774 samt Forbrukertvistutvalgets tidligere praksis vil feil som oppstår i løpet av femårsperioden på produkter som faller inn under denne regelen, bli ansett som kjøpsrettslige mangler, medmindre det er grunnlag for å mene at feilen er en følge av normal slitasje, brukerfeil f.eks. ytre påvirkninger av forskjellig type“. Da der ikke var holdepunkter for at antage, at brugen af maskinen havde været usædvanlig, fandtes maskinen at lide af en mangel, og klageren, der havde reklameret rettidigt, kunne kræve omlevering.

\section{FTU sak 20040356}

En forbruger, A, købte i februar 1999 et tv. Der blev givet 24 måneders garanti. I sin klage til Forbrukertvistutvalget angav A, at skærmen blev sort i januar 2003. Tre dage efter at have konstateret dette, reklamerede A til sælgeren, B. A fik øjensynligt det indtryk, at en eventuel reparation ville være omkostningsfri. Da han senere fik besked om, at tv'et nu var repareret, var beskeden, at der han skulle betale reparationsomkostningerne. A klagede herefter til Forbrukertvistutvalget med krav om omkostningsfri reparation. Forbrukertvistutvalget fastslog at, TVapparater måtte anses for omfattet af den 5-årige reklamationsfrist. Herefter udtalte udvalget: „Ifølge Høyesteretts dom i Rt. 1998 s. 774 samt Forbrukertvistutvalgets tidligere praksis vil feil som oppstår i løpet av femårsperioden på produkter som faller inn under denne regelen, bli ansett som kjøppsrettslige mangler, medmindre det er grunnlag for å mene at feilen er en følge av normal slitasje, brukerfeil f.eks. ytre påvirkninger av forskjellig type“. B havde „antydet“, at fejlen skyldtes støvansamlinger ud over det normale, men dette var ikke bekræftet fra sagkyndigt hold. På denne baggrund fandt Forbrukertvistutvalget, at tv'et led af en mangel, som A i henhold til kjøpslovens § 34, stk. 1, havde krav på blev afhjulpet uden omkostninger. Da reparationen var foretaget, skulle A have tv'et udleveret uden at betale noget herfor.

\section{FTU sak 20040176}

En forbruger, A, købte i november 1998 en vaskemaskine. Midt i et vaskeprogram ophørte maskinen med at fungere i september 2003. Den virkede nu alene, hvis A

\footnotetext{
${ }^{36}$ Se også NOU 1993:27, p. 62.
} 
holdt start-/sluk knappen inde under vasken. A indleverede maskinen til sælgeren, B, med henblik på reparation. Knappen blev udskiftet, og B afkrævede A omkostningerne til reparationen. Sagen blev forelagt Forbrukertvistutvalget, hvor A krævede omkostningsfri afhjælpning. Forbrukertvistutvalget konstaterede, at vaskemaskinen måtte anses for omfattet af 5-årsreklamationsreglen. Herefter udtalte udvalget: „Ifølge Høyesteretts dom i Rt. 1998 s. 774 samt Forbrukertvistutvalgets tidligere praksis vil feil som oppstår i løpet av femårsperioden på produkter som faller inn under denne regelen, bli ansett som kjøppsrettslige mangler, medmindre det er grunnlag for å mene at feilen er en følge av normal slitasje, brukerfeil eller annet forhold som kjøperen selv har risikoen for, f.eks. ytre påvirkninger av forskjellig type“. Udvalget konstaterede, at der i den foreliggende sag er „,ingenting, som tyder på, at klagerens bruk eller andre ytre påvirkninger har ført til, at av/påknappen har sluttet å virke“. På den baggrund fandt udvalget, at der forelå en mangel, som måtte anses for at have været til stede ved leveringen. A havde derfor krav på omkostningsfri reparation, jf. kjøpslovens § 34, stk. 1 .

\section{FTU sak 20030263}

En forbruger, A, købte i juni 1998 en strygepresser. Apparatet blev indleveret til reparation tre gange i løbet af reklamationsfristen på fem år. A blev afkrævet reparationsomkostninger af sælgeren, B. Sagen blev forelagt Forbrukertvistutvalget, hvor A krævede at få sine reparationsomkostninger dækket af B. Forbrukertvistutvalget konstaterede, at varen måtte anses for omfattet af den 5-årige reklamationsfrist. Herefter konstaterede udvalget: „Ifølge Utvalgets tidligere praksis vil feil som oppstår i løpet av femårsperioden på produkter som faller inn under denne regelen, bli ansett som kjøppsrettslige mangler, medmindre det er grunnlag for å mene at feilen er en følge av normal slitasje, brukerfeil eller annet forhold som kjøperen selv har risikoen for, f.eks. ytre påvirkninger. Utvalget viser i denne forbindelse også til Høyestretts dom i Rt. 1998.774 i en sak som gjelder en videospiller“. Såvel indklagede som producent gav i sagen udtryk for, at fejlene skyldtes manglende vedligeholdelse og andre brugerfejl. Da disse årsagsforklaringer imidlertid ikke var dokumenterede eller sandsynliggjort, fandt utvalget, at der i alle tre tilfælde havde været tale om mangler, som A derfor havde krav på at få afhjulpet omkostningsfrit. A havde derfor krav på at få reparationsomkostningerne dækket af B.

\section{FTU sak 20040350}

En forbruger, A, købte i december 1999 en bærbar minidisc afspiller. Der blev givet 24 måneders garanti. I juli 2003 forsvandt lyden fra de med afspilleren medfølgende høretelefoner. A reklamerede derfor senere samme måned til sælgeren, B, som sendte afspilleren til undersøgelse. Årsagen til fejlen blev imidlertid ikke fundet. Sagen blev forelagt for Forbrukertvistutvalget, hvor A krævede ophævelse, subsidiært omlevering eller afslag i købesummen. Forbrukertvistutvalget fandt under henvisning til Høyesterettsdommen Rt 1998-774 samt til forbrukertvistutvalgets tidligere praksis, at en minidisc afspiller måtte anses for omfattet af reglen om fem års reklamationsret. Forbrukertvivstutvalget udtalte herefter: „Av denne praksis følger det også at feil som oppstår i løpet av femårsperioden på produkter som faller inn under denne regelen, blir ansett som kjøppsrettslige mangler, med mindre det er grunnlag for å mene at feilen er en følge av normal slitasje, brukerfeil eller annet forhold som kjøperen selv har risikoen for, f.eks. ytre påvirkninger av forskjellig type“. Da der ikke forelå sådanne konkrete holdepunkter, var afspilleren mangelfuld, hvorfor A kunne gøre mangelsbeføjelser gæl- 
dende, jf. kjøpslovens § 30, stk. 1. Manglen blev anset for væsentlig, og A havde derfor ret til at hæve købet, jf. kjøpslovens § 39, stk. 1. Da A imidlertid havde haft en fuldt funktionsduelig afspiller i $3 \frac{1}{2}$ år, blev der foretaget et brugsfradrag efter kjøpslovens § 65, stk. 1 på 1/3 af købesummen (NOK 1.000).

Som det fremgår, er man gået langt i retning af at lempe forbrugerens bevisbyrde. Reglen om, at sælger har „bevisføringspligt“ synes at være blevet fortolket således, at en fejl ved en vare omfattet af 5-årsreglen anses for en mangel, hvis den opstår inden for 5-årsperioden, medmindre „der er grundlag for at mene“, at fejlen skyldes andre forhold. Når forbrugeren har godtgjort, at der foreligger en fejl ved varen, er det således herefter op til sælgeren at tilvejebringe grundlaget for at antage, at fejlen skyldes sådanne andre forhold. Det er ikke tilstrækkeligt for sælgeren at anføre andre mulige forklaringer (jf. sag 57). Sælgeren må „dokumentere eller sandsynliggøre“ (jf. sag 57), at der gør sig sådanne andre forhold gældende. Lempelsen af forbrugerens bevisbyrde praktiseres således i praksis på en sådan måde, at man reelt synes at operere med en formodningsregel til fordel for forbrugeren.

Det konstateres i de refererede sager, at der er tale om produkter omfattet af 5-årsreglen. For produkter omfattet af denne regel gælder, at der er en forventning om en særlig langvarig holdbarhed. Dette er den underliggende begrundelse for at operere med lempelsen af kravene til forbrugerens bevis også i sager, hvor manglen først har vist sig nogen tid efter leveringen.

For produkter, der er omfattet af 2-årsreglen, gælder formentlig samme lempelige vilkår for forbrugerens bevisførelse. Til støtte herfor kan anføres, at der i disse tilfælde vil være tale om situationer, hvor fejlen opstår relativt kort tid efter leveringen, hvilket - når der er tale om nye varer - ofte anføres som et indicium for, at der foreligger en oprindelig mangel. $^{37}$

\subsubsection{Svensk ret}

Uden for garantitilfælde

I svensk ret må der sondres mellem garantitilfælde og andre tilfælde. Er der ikke givet en særlig garanti for varen, har forbrugeren som hovedregel bevisbyrden for, at den påpegede mangel forelå på tidspunktet for risikoens overgang. ${ }^{38}$ Hovedreglen er dog i praksis modificeret. Bevistemaet er, hvorvidt fejlen beror på forkert brug eller uheld. Kan køberen løfte beviset for, at dette ikke er tilfældet - ud fra et relativt lavt be-

\footnotetext{
${ }^{37}$ Fra praksis kan henvises til sak 20030440 vedrørende en gallakjole. Der reklameres inden for 2-årsfristen og det fremgår ikke af sagen, om forholdet ville have været omfattet af den 5-årige reklamationsregel, hvis dette havde været aktuelt. Se ligeledes sak 1997/211.

${ }^{38}$ Prop.2001/ 02:134, afsnit 5.6.3.
} 
viskrav $^{39}$ - anses bevisbyrden for løftet. Dette princip blev fastslået i den nedenfor refererede sag vedrørende en forbrugertjenesteydelse.

\section{NJA 1991 s. 481}

En bådmotor blev repareret to gange af den samme reparatør. Ejeren af båden afviste at betale for den anden reparation, da han mente denne havde været nødvendiggjort af fejl begået i forbindelse med den første reparation. Reparatøren hævdede problemet skyldtes vandindtrængning. Ejeren havde bevisbyrden for, at det forholdt sig på denne måde. Beviskravet ansås dog for opfyldt derved, at den af ejeren angivne skadesårsag, på baggrund af en vidneforklaring afgivet af en sagkyndig haveriinspektør, fremstod som klart mere sandsynlig end den af reparatøren angivne. Ejeren af båden fik derfor medhold.

Ifølge denne afgørelse er det således tilstrækkeligt, at forbrugerens forklaring må anses for „klart mere sandsynlig“ end sælgerens. Sandsynlighedskravet anvendes også i nævnspraksis vedrørende løsørekøb. Den følgende sag viser dette:

\section{ARN 1992-5239}

Forbrugeren købte en vaskemaskine. Efter under to år gik den i stykker og forbrugeren reklamerede inden for toårsfristen. ${ }^{40}$ Det viste sig, at „packboxen“ og kuglelejet i maskinen var gået i stykker. Nævnet udtalte: „Det är i princip köparens sak att visa att felet fanns vid leveransen. Beviskravet när det gäller tekniska fel kan dock inte ställas alltför högt vid konsumentköp. I det aktuella fattet har felet visat sig på det sättet att en packbox och ett kullager gått sönder. Enligt nämndens mening framstår det som mera samnnolikt att detta beror på ett fel som fanns redan vid leveransen än på någon senare inträffad omständighet av det slag som säljaren angett som mögligt, d.v.s. att klädludd, trådar eller liknande kommit in i maskinen. Beviskravet för därmed anses uppfyllt“. Forbrugeren fik herefter medhold i sit krav om afhjælpning.

I denne sag var det tilstrækkeligt, at forbrugerens forklaring blot ansås for mere sandsynlig end sælgerens. Uden for garantitilfælde har forbrugeren således ifølge disse sager i princippet bevisbyrden for, at den påpegede fejl også forelå på tidspunktet for overgivelsen og dermed udgør en mangel, mens bevisbyrden anses for løftet, hvis forbrugerens forklaring af nævnet anses for mere sandsynlig end sælgerens.

De ovenfor refererede sager er alle fra før indførelsen af de nye regler i konsumentköplagen. I teorien ${ }^{41}$ refereres dog fortsat til NJA 1991 s. 481 som en central afgørelse. Det er indtil videre meget begrænset, hvad der

\footnotetext{
${ }^{39}$ Prop.2001/ 02:134, afsnit 5.6.3.

${ }^{40}$ Der var givet en et-årig garanti, men denne fik ingen betydning for sagen, da der reklameredes efter et år men inden for den almindelige to-års frist.

${ }^{41}$ Johnny Herre, Konsumentköplagen, En kommentar, 2. udgave, 2004, p. 250, note 123.
} 
findes af nyere praksis, der kan tegne et billede af gældende ret på dette punkt. En enkelt nyere sag belyser problemstillingen.

66. ARN Sag 2004-8066:

En forbruger, A, købte i januar 2004 en projektor af sælgeren, B. Efter 456 timers brug (efter ca. ni måneder) gik pæren i stykker. Af garantivilkårene for projektoren fremgik det, at garantien for pæren var seks måneder eller 2.000 timer. Af fabrikantens hjemmeside fremgik det, at levetiden for pæren var 3.000 timer. A forlangte herefter omlevering. Han gjorde gældende, at projektoren kun havde fungeret i $15 \%$ af den garanterede brændtid. I den konkrete sag fandt nævnet imidlertid, at garantitiden - uanset hvilken levetid for pæren, som A var stillet i udsigt var udløbet, da A først reklamerede ni måneder efter købet. Uden for garantitilfælde er det afgørende, om fejlen forelå på leveringstidspunktet. Det er som udgangspunkt forbrugeren, som skal bevise, at dette var tilfældet. Nævnet udtalte: På den i ärendet föreliggenda utredningen kan inte nämnden finna att Marcus Månsson - mot företagets bestridande - har förmått göra övervägande sannolikt att felet beror på något ursprungligt fel hos lampan“. Kravet blev derfor afvist.

Sagen giver indtryk af, at man fortsat anvender det samme kriterium, jf. sag nr. 63 ovenfor.

\section{I garantitilfælde}

I svensk ret er spørgsmålet om bevisbyrdeforhold i relation til tidspunktet for fejlens opståen i garantitilfælde indirekte reguleret i konsumentköplagen $\S 21 .^{42}$ Bestemmelsen lyder:

\footnotetext{
„Har säljaren eller någon annan för hans räkning genom en garanti eller liknande utfästelse åtagit sig att under en viss tid svara för varan eller en del därav eller för en egenskap hos varan, skall fel anses föreligga, om varan under den angivna tiden försämras i det avseende som utfästelsen omfattar.

Första stycket gäller inte, om det görs sannolikt att försämringen beror på en olyckshändelse eller därmed jämförlig händelse eller på vanvård, onormalt brukande eller något liknande förhållande på köparens sida.“
}

Ifølge denne bestemmelse skal det som udgangspunkt antages, at der foreligger en mangel, hvis der opstår funktionssvigt omfattet af garantien. Sælgeren har dog efter stk. 2 mulighed for at modbevise dette. Hertil kræves, at han „gør det sandsynligt“", at svigtet skyldes et af de i bestemmelsen nævnte forhold. Til illustration af reglen kan nævnes følgende sag:

\section{ARN 1993-2722}

Forbrugeren købte en ny bil med nybilsgaranti for 79.900 kr. Nogle dage efter købet opdagede han, at det trak med kold luft under rattet, hvorfor han klagede til

\footnotetext{
$254 \mathrm{ff}$.

${ }^{42}$ Om bestemmelsen se Johnny Herre, Konsumentköplagen, En kommentar, 2. udgave, 2004, p.
} 
sælgeren. Sælgeren siliconebehandlede bilen og afviste, at der var tale om en mangel. Forbrugeren fastholdt sin reklamation og bilen blev testet af Svensk Bilprovning, som gjorde anmærkning om koldluftstræk under rattet. Forbrugeren krævede nu ophævelse av købet. Sælgeren gjorde gældende, at trækket måtte skyldes fejlanvendelse. Nævnet udtalte: , För att säljaren skall undgå att ansvara för ett fel som reklameras under garantitiden måste denne göra sannolikt att felet har uppkommit på grund av en omständighet som är att hänföra till köparen“ . Nævnet fandt under hensyntagen til Bilprovningens udtalelse og sælgerens afhjælpningsforsøg samt sælgerens undladelse af at tilvejebringe modbevis, at koldlufttrækket måtte anses for en mangel. Nævnet tilføjede endvidere, at sælgeren , har inte heller genom någon utredning förmått göra sannolikt att felet är att hänföra till F“. På den baggrund fik forbrugeren medhold i sit krav.

Da der ikke var søgt at føre modbevis på anden måde end ved at angive nogle mulige alternative forklaringer på svigtet, forekommer sagen ret oplagt. Den besvarer imidlertid ikke spørgsmålet, om sælgeren har løftet bevisbyrden, hvis han (f.eks. ved hjælp af en sagkyndig erklæring) har sandsynliggjort en bestemt skadesårsag, men en anden skadesårsag forekommer mere sandsynlig. I en senere sag anvendes udtrykket „overvejende sandsynligt“:

\section{ARN Sag 2005-3753:}

En forbruger, A, købte i september 2004 en pc af sælgeren, B. I marts 2005 reklamerede A til B over, at pc'en låste, og at displayet udviste underlige farver. B svarede, at pc'en var skadet som følge af at være tabt, og at reparationen derfor ikke kunne udføres inden for garantien. A afviste at have tabt pc'en. A forlangte omlevering, alternativt afhjælpning. Nævnet udtalte, at har en sælger afgivet garanti, kan han kun undgå sit garantiansvar, hvis han kan dokumentere, at fejlen er opstået som følge af forbrugerens adfærd. Ved en samlet bedømmelse i den konkrete sag - hvor nævnet blandt andet inddrog fotos af skaden/displayet - anså nævnet det overvejende sandsynligt, at fejlen i displayet er opstået, mens pc'en var i A’s varetægt. Fejlen kunne derfor henføres til A’s adfærd, hvorfor A’s krav blev afvist.

Sammenfattende kan konkluderes, at det i svensk ret i garantitilfælde er sælgeren, der har bevisbyrden for, at der er tale om en oprindelig fejl. Også sælgeren kan løfte bevisbyrden gennem sandsynliggørelse.

\subsection{Reklamationsklemmen (?)}

Der gælder nu i samtlige nordiske lande undtagen Finland reklamationsfrister i forbrugerkøb, der adskiller sig fra de reklamationsfrister, der gælder for andre køb.

I dansk ret er reklamationsfristen i forbrugerkøb 2 år efter købelovens § 83, mens den i andre køb er 2 år efter købelovens $\S 54$, medmindre andet er aftalt. I norsk ret er reklamationsfristen i forbrugerkøb 2 eller 5 år i henhold til forbrukerkjøpsloven $\S 32$, stk. 2 og 3, mens den i andre køb som udgangspunkt er 2 år, jf. 
kjøploven § 32, stk. 2. Det samme gælder i islandsk ret, jf. lov om forbrugerkøb § 27, stk. 2 sammenholdt med lov om løsørekøb § 32, stk. 2. I svensk ret er reklamationsfristen i forbrugerkøb nu 3 år efter konsumentköplagen $\S 23$, stk. 3, mens den i andre køb som udgangspunkt er 2 år efter köplagen $\S 32$, stk. 2.

Da reklamationsfristen for forbrugeren over for forhandleren således ofte vil være længere end reklamationsfristen for forhandleren over for leverandøren/producenten, kan forhandleren komme til at befinde sig i det, man kunne kalde en „reklamationsklemme“. Heri ligger, at forhandleren ikke vil have mulighed for at videreføre reklamationer, han selv er blevet mødt med over for leverandøren. Forhandleren må derfor - alt andet lige - formodes at have en større interesse i at kunne afvise denne type krav fra forbrugeren end andre krav, som kan videreføres. Denne interesse for videreførelsesmuligheder kan også af og til spores i de sager, der indbringes til afgørelse.

Af den danske sag nr. 50, refereret ovenfor under 4.3.1, fremgår således at forhandleren som argument for ikke at være ansvarlig over for forbrugeren henviser til, at produktet ikke længere var dækket af garanti. Det fremgår af sagens bilag, at der hermed sigtes til producentens garanti. Argumentet må umiddelbart forstås sådan, at forhandleren ville have dækket tabet, hvis der havde været mulighed for at videreovervælte dette på producenten. ${ }^{43}$

I den norske sag nr. 54, refereret ovenfor under 3.2.2 nævnes ligeledes som et led i forhandlerens argumentation for, at der alene gælder en 2-årig og ikke en 5-årig reklamationsfrist i forholdet mellem forhandler og forbruger, at producenten normalt har givet 2-årige garantier.

I svensk ret er problemet nyt, og der foreligger endnu ikke praksis, der relaterer sig til det.

Det er vanskeligt at danne sig et overblik over, hvor udbredt problemet er i praksis i de nordiske lande. I Danmark er forholdet søgt klarlagt i CBS-undersøgelsen fra 2005. Det fremgår heraf (p. 57-58), at $46 \%$ af respondenterne (forhandlerne) havde en reklamationsret på mindre end 2 år over for leverandøren/producenten. Hermed må det anses for dokumenteret, at de „tekniske“ forudsætninger for, at forhandlerklemmen kan være et reelt problem, findes i hvert fald i dansk ret.

\subsection{Komparativ sammenfatning}

I relation til spørgsmålet om bevisbyrdeforhold og bevisstyrke kan undersøgelsens resultater sammenfattes sådan, at det hos de retsanvendende myndigheder i både Danmark, Norge og Sverige anses for udgangspunktet, at det efter 6-månedersfristens udløb er forbrugeren, der har bevisbyrden for, at en fejl ved et produkt var til stede på tidspunktet for over-

\footnotetext{
${ }^{43}$ Samme tankegang ses hos sælgeren i sag 4051/7-633 fra det danske forbrugerklagenævn.
} 
givelsen af varen og dermed udgør en mangel. I såvel norsk som svensk ret opereres imidlertid med relativt milde krav til forbrugerens bevisførelse. I norsk ret synes man gennem reglen om sælgerens „bevisføringspligt“ i realiteten at være tæt på at anvende en formodningsregel til fordel for forbrugeren også uden for 6-måneders fristen. Dette kommer i praksis særlig klart frem i sager, der er omfattet af den 5-årige reklamationsfrist. Medmindre der er holdepunkter for, at en fejl ved varen skyldes forbrugerens egne forhold eller lignende, anses forbrugeren for at have løftet bevisbyrden for, at der er tale om en oprindelig mangel. I svensk ret sondres mellem garantitilfælde og andre tilfælde. Er fejlen efter dens karakter omfattet af en garanti, har sælgeren bevisbyrden for, at denne skyldes forbrugerens forhold eller lignende. Er forholdet ikke omfattet af en garanti, har forbrugeren bevisbyrden, men denne lempes, således at det er tilstrækkeligt, at forbrugerens forklaring efter nævnets vurdering fremstår som mere sandsynlig end sælgerens. Hverken i norsk eller svensk ret synes der at være spor af en praksisændring efter indførelsen af formodningsreglen. I norsk ret er den centrale dom på området fortsat Rt 1998.766, og i svensk ret henvises i litteraturen fortsat til de ovenfor refererede afgørelser fra begyndelsen af 1990'erne. Sværere er det at bedømme situationen i dansk ret. Her er det helt afgørende indholdet af den af Forbrugerklagenævnet indhentede sagkyndige erklæring. Som udgangspunkt er det kun, hvis erklæringen er til fordel for forbrugeren, at denne får medhold. Støtter erklæringen den erhvervsdrivende i samme grad, som den støtter forbrugeren, slår reglen om, at bevisbyrden er forbrugerens, igennem, sådan at forbrugeren ikke får medhold, medmindre der gør sig særlige forhold gældende, som for eksempel at der er reklameret kort tid efter udløbet af seks måneders fristen. Forskellene mellem retssystemerne synes navnlig at bero på, at det danske forbrugerklagenævn selv indhenter sagkyndige vurderinger, mens dette som udgangspunkt er overladt til parterne i såvel det norske som det svenske system.

I relation til spørgsmålet om „reklamationsklemmen“ indeholder samtlige, nordiske retssystemer undtagen det finske, teknisk set kimen til problemet, i og med længden af reklamationsfristerne kan være forskellige i de forskellige led i omsætningskæden. Den empiriske undersøgelse foretaget i Danmark dokumenterer også, at fristerne meget ofte rent faktisk er forskellige. I hvilket omfang dette giver anledning til problemer i praksis, er det imidlertid vanskeligere at danne sig et indtryk af. Af enkelte afgørelser fremgår, at forhandlerens reklamationsmuligheder over for producenten har været berørt som tema i sagen, men der er ikke i den undersøgte praksis tydelige spor af, at forhandleren normalt anser egne reklamationsmuligheder for at være et relevant kriterium i relation til spørgsmålet om forbrugerens rettigheder over for ham. Dette udelukker selvsagt ikke, at denne form for argumentation rent faktisk forekommer i praksis i detailhandlen. 



\section{Uforholdsmæssigheds- vurderingen}

\subsection{Implementeringen af direktivets regel i de nordiske lande}

Direktivet indførte som noget nyt den hovedregel, at forbrugeren i tilfælde af mangler ved det solgte som udgangspunkt har ret til at vælge mellem afhjælpning af manglen eller omlevering af varen. Bestemmelsen findes i direktivets artikel 3, stk. 3, som fastslår:

I første omgang kan forbrugeren kræve at sælgeren afhjælper den manglende overensstemmelse eller omleverer, i begge tilfælde uden vederlag, medmindre dette ikke er muligt eller er uforholdsmæssigt.

Et krav om afhjælpning eller omlevering anses for uforholdsmæssigt, hvis den pågældende beføjelse vil påføre sælgeren omkostninger, der i forhold til omkostningerne ved den alternative beføjelse er urimelige under hensyn til

- den værdi, varen ville have, hvis den var i overensstemmelse med aftalen

- betydningen af den manglende overensstemmelse, og

- om den alternative beføjelse vil kunne gennemføres uden væsentlig ulempe for forbrugeren

Afhjælpning eller omlevering skal ske inden for rimelig tid og uden væsentlig ulempe for forbrugeren under hensyntagen til varens art og forbrugerens formål med at anskaffe varen.

Denne regel er implementeret på følgende måder i de nordiske lande:

I dansk ret findes reglen i købelovens § 78, stk. 2:

Køberen kan ikke kræve omlevering eller afhjælpning, hvis gennemførelsen af den valgte beføjelse er umulig eller vil påføre sælgeren uforholdsmæssige omkostninger. Der skal herved tages hensyn til salgsgenstandens værdi uden mangler, mangelens betydning, og om anden beføjelse kan gennemføres uden væsentlig ulempe for køberen.

I finsk ret i Konsumentskyddslagen kap. 5, § 18,1:

Köparen har rätt att kräva att säljaren inom skälig tid avhjälper felet genom att rätta till det eller avlämna en felfri vara så att köparen inte åsamkas kostnader eller väsentlig olägenhet. Säljaren är dock inte skyldig att avhjälpa felet, om det föreligger ett hinder som han inte kan övervinna eller det skulle medföra oskäliga kostnader för honom att avhjälpa felet med beaktande av felets betydelse och va- 
rans värde, om den var avtalsenlig, eller om rättelse kan ske på något annat sätt utan väsentlig olägenhet för köparen.

I islandsk ret i lov om forbrugerkøb § 29, stk. 1-2:

Forbrugeren kan vælge om han kræver at sælgeren afhjælper mangelen for egen regning eller kræver omlevering fra sælgeren. Dette gælder dog ikke hvis der foreligger hindring som sælgeren ikke kan overvinde eller det ville påføre sælgeren uforholdsmæssige omkostninger.

Ved vurdering af hvorvidt omkostningerne er uforholdsmæssige efter stk. 1 nr. 2 skal der tages hensyn til salgsgenstandens værdi uden mangel, mangelens betydning, og om køberen kan anvende anden beføjelse uden væsentlig ulempe.

I norsk ret i lov om forbrukerkjøp § 29, stk. 1-2:

Forbrukeren kan velge mellom å kreve at selgeren sørger for retting av mangelen eller leverer tilsvarende ting (omlevering). Dette gjelder ikke hvis gjennomføring av kravet er umulig eller volder selgeren urimelige kostnader.

Ved avgjørelsen av om kostnadene er urimelige etter første ledd annet punktum, skal det særlig legges vekt på verdien av en mangelfri ting, mangelens betydning og om andre beføyelser kan gjennomføres uten vesentlig ulempe for forbrukeren.

\section{I svensk ret i konsumentköplagen § 26, stk. 1-2:}

Köparen har rätt att kräva att säljaren avhjälper felet eller företar omleverans, om detta kan ske utan oskälig kostnad för säljaren.

Vid bedömningen av om någon av påföljderna avhjälpande eller omleverans skulle medföra oskälig kostnad för säljaren skall särskild hänsyn tas till vilken betydelse felet har, vilket värde varan skulle ha haft om den varit felfri och om den andra påföljden skulle kunna fullgöras till väsentligt lägre kostnad för säljaren och utan väsentlig olägenhet för köparen.

Direktivets hovedregel er, at forbrugeren i tilfælde af mangler frit kan vælge mellem afhjælpning og omlevering som misligholdelsesbeføjelser. Denne valgret for forbrugeren er en nyskabelse i nordisk ret. Valgretten er fremhævet i den norske og islandske regel gennem udtrykket „vælge/velge“. I Finland var der oprindelig fremsat forslag om en lignende formulering, ${ }^{44}$ men udtrykket „enlig eget val“ blev strøget af Ekonomiutskottet med følgende begrundelse:

Utskottet har strukit enligt eget val i bestämmelsen. Att lyfte fram köparens rätt att välja i lagen kan leda till oskäliga och ogrundadade byteskrav inte minst när skillnaden mellan varans värde och felet är oproportionerligt stor. I sin föreslagna form kan bestämmelsen betyda ökade meningsskilaktigheter mellan köpare och säljare och leda till utdragna besvärsprocesser. Utskottet har den uppfatningen att det i de flesta fall lönar sig bätre för både säljaren och köparen att byta ut en felak-

${ }^{44}$ Se udkast til 18 § i RP 89/2001, p. 35 „Köparen har rätt att enligt eget val kräva att säljaren inom skälig tid avhjälper felet genom att rätta till det eller avlämna en felfri vara utan kostnad eller väsentlig olägenhet för köparen...“. 
tig vara, speciellt när det gäller massproducerade varor, mot en felfri vara än att låta reparera den. En sådan råttelse rättelse kan gåtgärdas snabbt utan kostnader för köparen. Utskottet understryker att den genom denna ändring inte har avsett att försvaga konsumentens ställning. Avsikten är att hindra att det uppstår situationer som kan leda til orimligheter eller rentav till omotiverat missbruk av valgmöjligheten. ${ }^{45}$

I de danske og svenske forarbejder gøres ingen bemærkninger om muligheden af en sproglig fremhævelse af forbrugerens valgret.

For så vidt angår uforholdsmcessighedskriteriet er implementeringerne i de nordiske lande tæt ved identiske. I den norske bestemmelse har man valgt at bruge udtrykket „urimelige kostnader“ frem for „uforholdsmæssig“. Det fremgår imidlertid af den norske bestemmelse, at man ved den konkrete urimelighedsvurdering skal inddrage de samme kriterier, som er nævnt i direktivet. Det har således ikke været hensigten med den norske formulering at fastsætte en regel, der er indholdsmæssig forskellig fra direktivets regel. ${ }^{46}$ Også bestemmelserne i de øvrige nordiske lovgivninger fastslår, at det er de i direktivet nævnte kriterier, der skal anvendes ved den konkrete uforholdsmæssighedsvurdering. De angivne kriterier er i øvrigt næppe udtryk for en udtømmende opregning af relevante hensyn. ${ }^{47} \mathrm{I}$ den svenske bestemmelse er således også udover direktivets tre kriterier tilføjet et fjerde kriterium. Det fremgår således blandt andet af den svenske konsumentköplags $\S 26$, stk. 2, at det indgår som en integreret del af uforholdsmæssighedsvurderingen, om en anden beføjelse kan bringes i anvendelse „till väsentligt lägre kostnad för säljaren.“ Af forarbejderne til bestemmelsen fremgår, at dette kriterium betragtes som et „direkt uttryck för den jämförelse mellan påföljderna som direktivet anvisar i artikel 3.3. andra stycket, där det sägs att en påföljd skall anses oproportionell om den åsamkar säljaren kostnader som är orimliga i jämförelse med den alternativa påföljden“ ${ }^{48}$ Det kan tilføjes, at det i direktivets præambel også anføres: „...en beføjelse anses for uforholdsmcessig, hvis den vil påføre scelgeren omkostninger, der i forhold til omkostningerne ved en alternativ beføjelse er urimelige; omkostningerne er urimelige, hvis de er vcesentligt højere end omkostningerne ved en anden beføjelse“. Det svenske fjerde kriterium har således også direkte støtte i præamblen. ${ }^{49}$

For så vidt angår direktivets regel om, at umulighed kan udelukke krav på henholdsvis afhjælpning og omlevering, er det alene i Danmark og

\footnotetext{
${ }^{45}$ Se Ekonomiutskottets betänkande 18/2001 Rd, p. 4.

${ }^{46}$ Dette fremgår også af forarbejderne til reglen, jf. Ot.prp. nr. 44 (2001-2002), p. 183.

${ }^{47}$ Jf. herved Prop.2001/02:134, afsnit 9.1, bemærkninger til § 26 og Ot.prp. nr. 44 (2001-2002), bemærkningerne til § 29, p. 183.

${ }^{48}$ Prop. 2001/02: 134, p. 86.

${ }^{49}$ Hos Johnny Herre, Konsumentköplagen, En kommentar, 2. udgave, 2004, p. 314 omtales kriteriet „tillväsentligt lägre kostnad för säljaren“ ikke som „et fjerede kriterium” men läses i sammenhæng med resten af bestemmelsen, som tilføjer: „och ütan väsentlig olägenhet för köparen“.som et samlet „tredje kriterium“. Herved fremhæves betydningen af hensynet forbrugeren, ligesom det signaleres, at der ikke kan ses isoleret på omkostningskriteriet.
} 
Norge, at direktivets undtagelse om umulighed er implementeret direkte med ordlyden „umulig.“ Typeeksemplet på et tilfælde, hvor en beføjelse ikke kan bringes i anvendelse, vedrører køb af speciesgenstande, hvor forbrugeren forlanger omlevering som følge af en mangel. I disse tilfælde er det umuligt for sælgeren at opfylde dette krav, eftersom aftalen kun kan opfyldes med én genstand, nemlig den, der er leveret.

I Sverige er der slet ikke er indført en bestemmelse om umulighed. Af forarbejderne fremgår, at dette skyldes, at reglen efter svensk synsmåde er „självklar“, og derfor ikke behøver være skrevet ind i lovreglen. ${ }^{50}$

I Finland og Island benyttes formuleringen ,ett hinder som han [sælger] inte kan övervinna“, henholdsvis „hindring som sælgeren ikke kan overvinde“. Formuleringen svarer til formuleringen af kontrolansvaret i de nordiske købelove. Af de finske forarbejder fremgår også, at man ønskede at opfylde direktivets regel om umulighed ved at „ta in en bestämmelse som motsvarer $23 \S 1$ mom. köplagen ....“ . ${ }^{51}$ Ved at anvende denne formulering opnås således på det generelle plan en bedre sammenhæng i det køberetlige/obligationsretlige system. Det kan imidlertid diskuteres, om disse implementeringer er direktivkonforme. Således som kriteriet om umulighed er formuleret i direktivets art. 3, stk. 3, er der tale om en tilnærmelsesvis objektiv vurdering af, om det i det hele taget kan lade sig gøre at bringe en beføjelse i anvendelse. Det er ikke efter ordlyden af direktivets art. 3, stk. 3, afgørende, om det er umuligt for den konkrete sælger at opfylde et krav om afhjælpning eller omlevering. Den finske og den islandske implementering synes imidlertid at lægge afgørende vægt på et mere subjektivt kriterium, nemlig om den konkrete sælger kunne have overvundet hindringen for anvendelsen af beføjelsen. I praksis vil denne forskel i ordlyd imellem den danske og den norske implementering på den ene side og den finske og den islandske på den anden dag næppe føre til væsentlige forskelle i retstilstanden.

\subsection{Uforholdsmæssighed i praksis}

\subsubsection{Omlevering som uforholdsmæessig i forhold til afhjcelpning (retning)}

\subsubsection{Indledning}

Der foreligger en del praksis fra Danmark, Norge og Sverige, hvor uforholdsmæssighedskriteriet har stået sin prøve. Uforholdsmæssighedsvurderingen består af tre elementer. Det skal først konstateres, om den valgte beføjelse i det hele taget påfører sælgeren omkostninger. Er det tilfældet, skal det dernæst vurderes, hvorvidt disse omkostninger er højere end

\footnotetext{
${ }^{50}$ Se Prop.2001/902:134, p. 51, hvor det anføres, at umulighedskriteriet må antages at følge af KKpl. 28 §, første stykke.

${ }^{51}$ RP 89/2001, p. 17.
} 
omkostningerne ved en anden beføjelse. Sluttelig skal det afgøres, om en nu konstateret omkostningsforskel er uforholdsmæssig.

Det generelle indtryk er ikke overraskende, at der i vid udstrækning foretages en helhedsvurdering. De relevante kriterier i uforholdsmæssighedsvurderingen - salgsgenstandens værdi, manglens betydning og muligheden for at gennemføre anden beføjelse uden væsentlig ulempe for forbrugeren - behandles som en del af en samlet vurdering, således som direktivet også lægger op til.

I det følgende belyses de kriterier, der inddrages i forholdsmæssighedsvurderingen. Der tages udgangspunkt i de kriterier, der er nævnt i direktivet, men som anført ovenfor, kan direktivet ikke anses for udtømmende på dette punkt. Som det vil fremgå inddrages således i praksis også kriterier, som ikke (direkte) er nævnt i direktivet.

\subsubsection{Uforholdsmæssighedskriterier}

\section{Det overordnede kriterium}

Det fremgår af art. 3, stk. 3, og af samtlige nordiske lovgivninger, at man ved uforholdsmæssighedsvurderingen helt overordnet skal se på, om omkostningerne forbundet med gennemførelse af omlevering må anses for uforholdsmæssige i forhold til omkostningerne forbundet med afhjælpning. Der skal med andre ord ses på meromkostningerne. I en række tilfælde foretages uforholdsmæssighedsvurderingen tilsyneladende alene ud fra dette overordnede kriterium uden inddragelse af de efterfølgende tre hjælpekriterier.

Reglen rejser spørgsmålet, hvordan de omkostninger, der skal sammenlignes med, skal beregnes. For så vidt angår afhjælpningsomkostningen, vil det ofte være uproblematisk at angive denne til udbedringsomkostningen. Fastsættelsen af afhjælpningsomkostningerne kan imidlertid give anledning til problemer.

I danske forbrugerklagenævnssager er det spørgsmål således opstået, om den sælger, der har mulighed for vederlagsfrit at videresende varen til reparation hos producenten, kan kræve afhjælpningsomkostningerne ansat til $0 \mathrm{kr}$. ved foretagelsen af uforholdsmæssighedsvurderingen. Problemet med denne synsmåde ville i givet fald være, at de reelle omkostninger ved afhjælpning ikke er $0 \mathrm{kr}$. men blot er mindre synlige, fordi de i stedet afholdes af producenten, som må antages helt eller delvis at have overvæltet omkostningerne på sælgeren gennem prisfastsættelsen. Samfundsmæssigt set vil afhjælpning derfor altid have omkostninger, men dette forhold kan være vanskeligt at håndtere „på mikroniveau“ i en uforholdsmæssighedsvurdering i forholdet mellem sælgeren og forbrugeren. Det danske forbrugerklagenævn har ikke udtrykkeligt taget stilling til problemet, men har løst de konkrete tvister ved i stedet at inddrage den ombyttede vares genanskaffelsesværdi, jf. nærmere nedenfor.

Også fastsættelsen af udgiften forbundet med omlevering kan give anledning til tvivl. Der vil praktisk taget altid være forskel på den pris, sælgeren indkøber sine varer til, og den pris, varerne videresælges til forbru- 
gerne for. Når det skal vurderes, om en forbrugers krav om omlevering frem for afhjælpning skal opfyldes, kan det spørgsmål derfor rejses, om det er sælgerens indkøbspris eller salgsprisen, som skal lægges til grund for afgørelsen af merudgiftsvurderingen. I norsk ret var det Lagmannsrettens opfattelse i sag 82 refereret nedenfor, at indkøbsprisen må anses for den relevante. ${ }^{52}$ Det taler for denne løsning, at man herved undgår en situation, hvor sælger alene ved at henvise til et tab af avance skulle være berettiget til at afvise en forbrugers krav om omlevering.

Også i dansk forbrugerklagenævnspraksis antager man, at indkøbsprisen er den relevante. Her er man imidlertid gået et skridt videre, idet man antager, at indkøbsprisen yderligere skal fradrages det beløb, som den reparerede vare må antages at kunne videresælges til som brugt vare.

\section{Sag 2002-4051/7-93: køb af mobiltelefon}

En forbruger, A, havde købt en mobiltelefon, der halvanden måned efter leveringen begyndte periodisk at slukke ved afsendelse af sms-beskeder. Den erhvervsdrivende, B, henviste A til at få fejlen afhjulpet i en Nokia Butik. Fejlen viste sig imidlertid atter to uger efter, A havde fået mobiltelefonen retur fra butikken. A krævede herefter mobiltelefonen omleveret. B lod mod A's protest fejlen afhjælpe under henvisning til, at producenten ville udbedre fejlen uden udgift for A. A fastholdt imidlertid sit krav om omlevering. Forbrugerklagenævnet fandt for det første, at A havde reklameret rettidigt. Herefter konkluderede nævnet, at A havde ret til at hæve købet, idet en ombytning alene ville påføre B en merudgift på kr. 156. Der blev ved vurderingen af omkostningerne ved omlevering i forhold til omkostningerne ved afhjælpning lagt vægt på, at den defekte mobiltelefon kunne istandsættes og gensælges som lettere brugt, hvorved B’s udgift til omlevering blev reduceret. Nævnet fremhævede udtrykkeligt, at der hverken i lovens forarbejder eller i øvrigt var grundlag for i uforholdsmæssigheds-vurderingen at tage hensyn til, at indklagede ikke kunne opnå avance ved salg af ombytningstelefonen. Herudover bemærkede nævnet, at da indklagede allerede én gang havde haft mulighed for at afhjælpe manglen, ville der skulle meget til, for at fravige udgangspunktet om forbrugerens valgret. Nævnet bemærkede derudover, at afhjælpning ikke var sket inden rimelig tid, og at et krav om omlevering derfor også kunne støttes på købelovens § 78, stk. 4.

\section{Sag 4031/7-1146}

En forbruger klagede efter to måneder over en printers farveskrift, idet sort/hvide fotos nærmest blev udskrevet i farve, mens den blå farve slet ikke blev udskrevet. Der var enighed om, at der forelå en mangel, og forbrugeren krævede omlevering. Spørgsmålet var, om sælgeren kunne afvise dette under henvisning til en uforholdsmæssighedsbetragtning. Forbrugerklagenævnet fastslog her, at udgangspunktet er valgret for forbrugeren. Dernæst fastslog man, at det forhold, at en mangel lader sig afhjælpe let eller billigt ikke uden videre er tilstrækkeligt til, at et krav om omlevering kan anses for uforholdsmæssigt, ,idet de ved vurderingen tillige må tages hensyn til forbrugerens interesse i den valgte beføjelse, ligesom det

\footnotetext{
${ }^{52}$ Visse, navnlig ressourcestærke, sælgere som supermarkeder mv. indkøber undertiden varer til en højere pris end den, de videresælger den for ("slagtilbud”). I disse tilfælde finder de anførte betragtninger ikke anvendelse.
} 
vil skulle indgå i vurderingen, hvilke muligheder sælgeren har med hensyn til at reparere og sælge den ombyttede genstand til anden side som lettere brugt“. Nævnet lagde endvidere til grund, at merudgiften ved omlevering frem for reparation måtte beregnes som forskellen mellem indkøbsprisen på 706,76 kr. for en ny printer og videresalgsprisen for den reparerede printer. Da klageren havde købt en genstand, som han dagligt havde brug for, fandtes et omleveringskrav ud fra en samlet vurdering ikke uforholdsmæssigt.

I sag 69 fremhæves udtrykkeligt, at der ikke i uforholdsmæsssighedsvurderingen kan tages hensyn til tabt avance for sælgeren på ombytningsvaren. Afgørelserne er i øvrigt interessante derved, at de udover at lægge vægt på den beskedne merudgift, omlevering vil medføre for sælgeren, også pointerer, at sælgeren blot kan istandsætte den mangelfulde genstand (mobiltelefon) og derefter gensælge denne som lettere brugt. ${ }^{53} \mathrm{I}$ begge sager var der tale om helt nye varer med klar genanvendelsesværdi. Det må især være i disse tilfælde, at kriteriet kan finde anvendelse.

\section{Genstandens væerdi uden mangler}

Efter direktivet og samtlige nordiske lovgivninger skal ved uforholdsmæssighedsvurderingen henses til genstandens værdi uden mangler. Det fremgår ikke, på hvilken måde genstandens værdi skal indgå i vurderingen, eksempelvis om lav værdi taler for eller imod omlevering. I de norske forarbejder anføres, at der „ved salg af billige varer sjeldnere vil være grunnlag for å nekte omlevering enn ved salg av kostbare varer““ ${ }^{54}$ På tilsvarende vis hedder det i de danske forarbejder:

„Kræver forbrugeren omlevering af en salgsgenstand af mindre værdi, vil der langt sjældnere være grundlag for at fravige udgangspunktet om forbrugerens valgret, end i de tilfælde, hvor købet vedrører en kostbar genstand. Der er således forskel på, om der kræves omlevering af eksempelvis et krøllejern til 200 kr. eller af en fabriksny personbil“. ${ }^{55}$

I forarbejderne lægges således op til, at lav værdi normalt vil tale for omlevering, mens høj værdi vil tale mod omlevering. Dette er også den måde kriteriet som oftest (men ikke altid) anvendes på i praksis.

I norsk ret blev der blandt flere andre ting sat fokus på betydningen af varens værdi i den følgende sag, som grundlæggende drejede sig om betydningen af, at der var tale om en masseproduceret vare til en moderat pris.

\footnotetext{
${ }^{53}$ I de omhandlede sager bestod netop det ovenfor beskrevne problem i relation til fastsættelsen af afhjælpningsomkostningerne, idet sælgeren vederlagsfrit kunne få manglerne afhjulpet af producenten.

${ }^{54}$ Ot.prp. 44, (2001-2002), bemærkninger til § 29, p. 183.

${ }^{55}$ FT (2001-2002), Tillæg A, p. 351.
} 


\section{Sak $2003 / 106$}

Klageren havde købt et par støvler til kr. 1360. Kort tid efter købet faldt den ene hæl af. Forhandleren tilbød afhjælpning, men klageren ønskede at hæve købet, hvilket forhandleren efter det af klageren oplyste, havde lovet klageren, at hun kunne, hvis hælen mod forventning skulle falde af. Klageren ønskede derfor nu i det mindste omlevering.

Forbrukertvistutvalget fandt ikke, at klagerens krav om omlevering medførte uforholdsmæssige omkostninger for forhandleren, og henviste i den forbindelse blandt andet til, at der var tale om en masseproduceret vare, som sædvanligvis lagerføres af forhandlere, og at varens væerdi målt efter pris i indkøb til forhandler og i salg til forbruger, er moderat.

Sagen blev herefter indbragt for tingsretten, som nåede til det modsatte resultat. Retten fandt, at det „i den aktuelle sammenhengen“ ikke naturligt „å karakterisere støvletter i den aktuelle prisklasse som en masseprodusert forbruksvare med beskjeden verdi“. Retten tilføjede: „Dersom kunden i et tilfelle som det omhandlede skulle ha et ubetinget krav på omlevering, kun ut fra verdien på varen, ville det innebære at stort sett alle sko, en rekke klær m.v. som hadde en mangel, ville bliv vraket. Retten finder dette bl.a. strider mod det miljøhensyn, som skal hensyntas. Dette gjelder spesielt dersom forholdet er, at mangelen kan utbedres raskt og på en fullgod måte“. Afgørende for retten var herefter, at meromkostningerne ved omlevering set i forhold til afhjælpning udgjorde 380 NKR, svarende til det seksdobbelte af afhjælpning, og at disse omkostninger måtte anses for uforholdsmæssige, når det blev taget i betragtning, at manglen ville kunne udbedres på 2-3 dage, og at støvletten efter en udbedring både kvalitetsmæssigt og udseendemæssigt ville være lige så gode som et par nye støvletter.

Sagen blev anket til Lagmannsretten, som ændrede tingsrettens afgørelse ${ }^{56}$. Lagmannsretten slog fast, at uforholdsmæssighedsvurderingen indebærer en „bred og sammensatt vurdering“ med udgangspunkt i om sælgerens omkostninger ved omlevering vil være urimelige set i forhold til en reparation. Man fastslog endvidere, at direktivets tre kriterier er centrale men ikke udtømmende. Lagmannsretten lagde herefter til grund, at de faktiske omkostninger ved en omlevering af støvletterne ville beløbe sig til 447 NKR. Dette beløb ville efter Lagmannsrettens opfattelse isoleret set ikke være en urimelig omkostning „,selv om beløbet er vesentlig høyere enn selgerens kostnad ved reparasjon“. Retten inddrog herefter direktivets tre kriterier, og fandt i relation til værdien af varen i manglfri tilstand, at værdien af et par støvletter til 1360 NKR ikke var betydelig set i sammenhæng med, at forbrugerkøb kan omfatte køb af genstande til flere hundrede tusinde kroner. I relation til betydningen af manglen, fandt retten, at denne var væsentlig, idet manglen havde betydning for varens funktion. For så vidt angik spørgsmålet om muligheden for at gennemføre den alternative beføjelse (afhjælpning) uden ulempe for forbrugeren, fandt retten, at afhjælpning ville kunne gennemføres uden væsentlig ulempe for forbrugeren. Endelig inddrog Lagmannsretten som et yderligere kriterium det miljømæssige hensyn men anførte her, at dette ikke entydigt talte mod omlevering, da gennemtvingelse af omleveringskrav ville kunne medføre en generelt større kvalitetsbevidsthed hos producenter og dermed medvirke til nedsættelse af antallet af mangelfulde varer. Ud fra en samlet vurdering kom Lagmansretten herefter til, at forbrugeren havde krav på omlevering. Retten fremhævede, at man i denne sammenhæng lagde vægt på ,at lovens hovedregel er at forbrukeren har krav på omlevering, og at der derfor skal en del til for at selgeren kan møte dette

\footnotetext{
${ }^{56}$ Se Eidsvitating Lagmannsretts afgørelse af 31. marts 2005, sag nr. 04-027856ASI-ELAG
} 
kravet med et tilbud om reparasjon. Særlig må dette gjelde innenfor et så sentralt området for forbrukerkjøp som kjøp av sko“. Lagmannsretten fremhævede endvidere, at det i den konkrete sag var helt centralt, at manglen var væsentlig, og på det generelle plan, at det var vigtigt at have regler og praksis, „som er lette og enkle å praktisere“ for at undgå at gøre forbrugerens valgret mindre reel.

Sagen blev anket til Høyestrett, som i en 3-2 afgørelse stadfæstede tingsrettens dom og afviste forbrugerens krav på omlevering. Flertallet af dommere lagde vægt på, at det norske urimelighedskriterieum må fortolkes i overenstemmelse med direktivets forholdsmæssighedskriterium, og det afgørende derfor ikke var, at meromkostningsbeløbet i absolut tal alene beløb sig til omkring 400 N.KR., men derimod at omleveringsomkostningerne var 7 gange højere end afhjælpningsomkostningerne. Flertallet anførte endvidere, at spørgsmålet måtte vurderes i et noget bredere perspektivt, og at en udstrakt pligt til omlevering ville indebære, at man „med loven i hånd“ etablerede en „bruk og kast-ordning“, „,som det generellt kan være grunn til å ta avstånd fra“ I et obiter dictum anførtes endvidere, at omleveringsomkostninger normalt vil skulle anses for uforholdsmæssigt store (og dermed urimelige), hvis de blot er 2 eller 3 gange så store som afhjælpningsomkostningerne. Forbrugerens krav afvistes herefter. Mindretallet anførte, at også det absolutte merbeløb forbundet med omlevering måtte være relevant ved foretagelsen af forholdsmæssighedsvurderingen, og at miljømæssige betragtninger kun i sager vedrørende visse typer af produkter som hårde hvidevarer taler mod omlevering. I følge mindretallet burde forholdsmæssigehdsvurderingen praktiseres sådan, at forbrugerens valgret som hovedregel slår igennem, når der er tale om „rimeligere, masseproduserte varer, og der reparasjonen ikke kan skje umiddelbart på stedet“. Mindretallet fandt på den baggrund, at forbrugeren måtte gives medhold.

Som det fremgår, spillede det for Lagmannsretten en væsentlig rolle at markere, at der er realitet i den valgret, som forbrugeren efter den norske lovbestemmelse udtrykkeligt er indrømmet. I relation til spørgsmålet om betydningen af varens værdi er Lagmannsrettens afgørelse interessant, fordi den lægger op til, at den klare hovedregel må være, at der kan kræves omlevering, når det drejer sig om en væsentlig mangel ved en masseproduceret vare, der sammenlignet med de mest værdifulde forbrugsvarer ikke kan betegnes som specielt værdifuld. Lagmannsrettens synspunkter blev imidlertid kun fulgt af mindretallet i Høyesterett. Med flertallets afgørelse må det antages at ligge fast, at den omstændighed, at der er tale om billige, masseproducerede varer ikke er et afgørende argument for, at omlevering skal kunne kræves. Der skal under alle omstændigheder foretages en forholdsmæssighedsvurdering. Er omkostningerne forbundet med omlevering 7 gange højere end afhjælpningsomkostningerne (eller endnu højere) følger det af afgørelsen, at et omleveringskrav som udgangspunkt må anses for uforholdsmæssigt. Grænsen vil dog formentlig også for de billigere masseproducerede varer - ligge noget lavere, jf. herved afgørelsens obiter dictum. Den opstillede regel er formentlig begrænset til direkte kun at angå varer, der for eksempel på grund af slid ikke kan genanvendes. ${ }^{57}$

${ }^{57}$ Jf. herved Hagstrøm, p. 2003: „For rimelige gjenstander som faller betydelig i pris etter kort tids bruk, må det således antas at kjøpers omleveringskrav er ,uforholdsmessig ' i direktivets forstand, og at et krav om omlevering kan volde selgeren ,urimelige kostnader‘, jfr. § 29 første ledd“. 
I dansk praksis er kriteriet „,varens værdi“ ikke blevet underkastet tilsvarende indgående overvejelser, men der findes forbrugerklagenævnspraksis, der inddrager kriteriet.

78. Sag 4031/7-496

Klageren havde købt en pc for kr. 10.216. Ca. tre uger efter købet ophørte pc'en med at virke. Klageren reklamerede og indleverede pc'en til den erhvervsdrivende. Efter 4 dage fik klageren pc'en retur. Pc'en var stadig ikke i orden. Klageren reklamerede derfor til den erhvervsdrivende og ønskede at hæve købet. Den erhvervsdrivende tilbød afhjælpning. Forbrugerklagenævnet udtalte, at det var op til den erhvervsdrivende at godtgøre, at der ikke havde været pligt til at tilbyde omlevering som følge af, at denne beføjelse ville påføre den erhvervsdrivende uforholdsmæssige omkostninger. Et flertal i nævnet fandt det, under hensyntagen til pc'ens væerdi og en sagkyndigs vurdering, godtgjort, at den erhvervsdrivende havde været berettiget til alene at tilbyde afhjælpning, da det ville have været uforholdsmæssigt for den erhvervsdrivende at foretage omlevering i forhold til afhjælpning. Henset til, at den erhvervsdrivende havde haft et afhjælpningsforsøg, som tog fire dage, fandt flertallet, at den erhvervsdrivendes yderligere tilbud om afhjælpning havde været berettiget. Et mindretal fandt klageren berettiget til at hæve.

I denne afgørelse talte varens værdi mod omlevering. Det må antages, at man hermed har ment, at der var tale om en vare af forholdsvis høj værdi (ca. $10.000 \mathrm{kr}$.). Anvendes det norske kriterium, hvorefter der sammenlignes med de allerdyreste forbrugsvarer til flere hundrede tusinde kroner, er det mere tvivlsomt, om varen ville være blevet anset for så værdifuld, at dette talte mod omlevering.

At lav værdi af en vare ikke altid taler for omlevering fremgår tydeligt af to sager fra det danske forbrugerklagenævn, hvor man udtrykkeligt lod varens lave værdi tale mod omlevering.

75. Sag 2003-62/7-70

En forbruger, A, købte et par støvler, som efter ca. 4 måneders brug gik fuldstændigt fra i læder og sål. A reklamerede til den erhvervsdrivende, B, og det blev aftalt, at en skomager skulle vurdere skaden for at bekræfte, at støvlerne var helt slidt op. Da A hentede støvlerne, var de uden samtykke blevet repareret. A ønskede omlevering i stedet for afhjælpning, hvilket B afviste. Forbrugerklagenævnet udtalte, at støvlerne havde været mangelfulde, men at manglen nu var afhjulpet. Der blev herefter lagt afgørende vægt på, at støvlerne fremtrådte som godt brugte og dermed som værende brugt en væsentlig del af deres forventede levetid. Støvlernes værdi uden manglen måtte derfor anses for beskeden, og manglen var af en karakter, som det var muligt at afhjælpe inden rimelig tid. Nævnet lagde derfor til grund, at en omlevering ville have påført $\mathrm{B}$ uforholdsmæssige omkostninger, hvorfor B ikke havde haft pligt til at tilbyde A omlevering. Efter afhjælpningen fremstod støvlerne med en mindre kosmetisk fejl, som dog ikke berettigede til ophævelse, men derimod til et mindre afslag i købesummen (kr. 150). 
Afgørelsen illustrerer, at omfanget af forbrugerens brug i sig selv kan medføre, at et krav om omlevering afvises. ${ }^{58}$

Det samme synspunkt gjorde sig gældende i den følgende sag.

77. Sag nr. 4051/7-496

Klageren havde købt en mobiltelefon til kr. 3.574. Cirka et år efter opstod der fejl ved telefonen, Klageren henvendte sig til en autoriseret reparatør, som opdaterede telefonen, hvorved fejlen forsvandt. Knap to år efter købet reklamerede klageren atter over nogle fejl. Klageren forlangte nu omlevering, mens den erhvervsdrivende tilbød afhjælpning. Forbrugerklagenævnet udtalte, at da fejlen, som udgjorde en mangel, først viste sig på et tidspunkt, hvor telefonen havde været i brug i næsten to år, og hvor telefonens vedligeholdelsesstand var under middel med tydelig slitage, var indklagede berettiget til som udgangspunkt at afvise klagerens ombytningskrav, da fejlen viste sig første gang. Den erhvervsdrivende havde imidlertid ikke afhjulpet manglen, og da der heller ikke var tilbudt øjeblikkelig afhjælpning, kunne den erhvervsdrivende ikke antages at have afhjulpet manglen inden for rimelig tid og uden væsentlig ulempe for klageren, som derfor kunne ophæve købet.

Lang tids anvendelse inden reklamationen må således antages at være et forhold, der kan tale mod omlevering. ${ }^{59}$ Sagerne illustrerer, at den forbruger, som i betydeligt omfang har anvendt salgsgenstanden og dermed draget nytte af dennes egenskaber, ikke uden videre kan påregne at få medhold $\mathrm{i}$ et krav om at få en helt ny genstand, selvom den oprindelige genstand led af en mangel. Ræsonnementet minder om det, der findes i KBL § 57, hvorefter køberen kun kan hæve, dersom varen kan leveres tilbage i væsentlig samme stand, som den var i, da den blev solgt. Kan sælgeren i disse tilfælde foretage afhjælpning på en sådan måde, at manglen afhjælpes, kan forbrugeren heller ikke kræve omlevering, selv om afhjælpningen måtte resultere i „mindre kosmetiske fejl.“ Uden for brugstilfældene vil lav værdi dog formentlig i de fleste tilfælde være et moment, der taler for omlevering.

\section{Manglens betydning}

Der skal efter direktivet og samtlige nordiske lovbestemmelser tages hensyn til „manglens betydning“ ved uforholdsmæssighedsvurderingen. Det fremgår ikke nærmere, hvordan dette kriterium skal forstås. Der kan enten tænkes på manglens betydning for køberen, hvis han beholder varen og/eller for sælgeren, hvis varen omleveres. Der foreligger tilsyneladende kun en enkelt sag, hvor man udtrykkeligt har inddraget kriteriet „manglens betydning“ for køberen. Det er den norske sag (82) refereret ovenfor. ${ }^{60}$ I denne sag fremhæves således udtrykkeligt, at det har afgørende betydning for resultatet i sagen, at der er tale om en væsentlig mangel ved varen. Afgørelsen skal således ikke tages til indtægt for, at hovedreglen

\footnotetext{
${ }^{58}$ Se tilsvarende sag 76 refereret nedenfor under 5.2.3 om uforholdsmæssighedsvurderingen i andre sammenhænge, og sammenhold Høyesteretts afgørelse i sag 82.

${ }^{59}$ Se endvidere sag 76, refereret nedenfor under 5.2.3.

${ }^{60}$ Se også sag 76 refereret nedenfor under 5.2.3.
} 
om køberens valgret vil slå lige så stærkt igennem, dersom der drejer sig om uvæsentlige mangler. Herved kommer vurderingen af, om der kan kræves omlevering, til at minde lidt om den tidligere gældende regel, hvorefter væsentlighed var en betingelse for, at der kunne kræves omlevering.

I en række danske afgørelser inddrages spørgsmålet om betydningen af manglen for sælger, dersom der gennemføres omlevering, jf. afsnittet nedenfor om omkostningsberegningen.

\section{Muligheden for at gennemføre den alternative beføjelse uden vasentlig} ulempe for forbrugeren

I forholdsmæssighedsvurderingen skal efter direktivet inddrages „om den alternative beføjelse vil kunne gennemføres uden væsentlig ulempe for forbrugeren“. Denne del af direktivet er også implementeret direkte i de nordiske landes købelove. ${ }^{61}$

I praksis er kriteriet udtrykkeligt blevet anvendt af Tingsretten i den ovenfor refererede norske sag (82). Her lagde man vægt på, at manglen ville kunne afhjælpes hurtigt (inden for 2-3 dage), og at støvletterne både visuelt og med hensyn til kvalitet ville være lige så gode som et par nye støvletter efter en afhjælpning.

Også danske afgørelser inddrager kriteriet.

\section{Sag 4031/7-1146}

En forbruger klagede over en printers farveskrift, idet sort/hvide fotos nærmest blev udskrevet i farve, mens den blå farve slet ikke blev udskrevet. Der var enighed om, at der forelå en mangel, og forbrugeren krævede omlevering. Spørgsmålet var, om sælgeren kunne afvise dette under henvisning til en uforholdsmæssighedsbetragtning. Forbrugerklagenævnet fastslog her, at udgangspunktet er valgret for forbrugeren. Dernæst fastslog man, at det forhold, at en mangel lader sig afhjælpe let eller billigt ikke uden videre er tilstrækkeligt til, at et krav om omlevering kan anses for uforholdsmæssigt, ,idet de ved vurderingen tillige må tages hensyn til forbrugerens interesse i den valgte beføjelse, ligesom det vil skulle indgå i vurderingen, hvilke muligheder sælgeren har med hensyn til at reparere og sælge den ombyttede genstand til anden side som lettere brugt“. Nævnet lagde endvidere til grund, at merudgiften ved omlevering frem for reparation måtte beregnes som forskellen mellem indkøbsprisen på 706,76 kr. for en ny printer og videresalgsprisen for den reparerede printer. Da klageren havde købt en genstand, som han dagligt havde brug for, fandtes et omleveringskrav ud fra en samlet vurdering ikke uforholdsmæssigt.

\section{Sag 2002-4051/7-1341: køb af mobiltelefon}

En forbruger, A, købte en mobiltelefon, hvor bagbeklædningen efter halvanden måned gik løs. A krævede derfor telefonen omleveret. Den erhvervsdrivende, B, oplyste, at det var nødvendigt at lade telefonen undersøge på et værksted for at afgøre, om den skulle omleveres. En sådan undersøgelse ville tage ca. 14 dage. A blev ikke tilbudt en erstatningstelefon. A fastholdt kravet om omlevering og ind-

\footnotetext{
${ }^{61}$ Se ovenfor afsnit 5.1 .
} 
bragte sagen for Forbrugerklagenævnet, hvis sagkyndige oplyste, at en reparation ville koste ca. kr. 300. Ved uforholdsmæssighedsvurderingen lagde forbrugerklagenævnet vægte på, at der var tale om en genstand, som forbrugeren havde daglig brug for, og at forbrugeren hverken var blevet tilbudt øjeblikkelig reparation eller en erstatningstelefon. Der ville herefter - efter nævnets opfattelse - skulle meget til for at fravige udgangspunktet om forbrugerens valgret. Da den ombyttede telefon ville kunne repareres og herefter gensælges som lettere brugt, fandt nævnet efter en samlet vurdering, at B - selv om den foreliggende mangel kunne afhjælpes for et mindre beløb - ikke havde godtgjort, at den beføjelse, som A havde valgt (omlevering), ville påføre B uforholdsmæssige omkostninger. A's omleveringskrav var derfor berettiget.

Som det fremgår anerkendes i disse sager, at den omstændighed, at afhjælpning kan foretages på en nem og billig måde, er momenter, der inddrages, men at det også må tillægges betydning, om køberen i det konkrete tilfælde har et særligt behov for at kunne anvende genstanden med det samme. I den forbindelse tillægges det betydning, om køberen er blevet tilbudt en erstatningsgenstand. Det kan også inddrages i vurderingen, om sælgeren tidligere har forsøgt at afhjælpe den samme mangel. Dette fremgår blandt andet af den følgende sag.

\section{Sag 4031/7-496}

Klageren havde købt en pc for kr. 10.216. Ca. tre uger efter købet ophørte pc'en med at virke. Klageren reklamerede og indleverede pc'en til den erhvervsdrivende. Efter 4 dage fik klageren pc'en retur. Pc'en var stadig ikke i orden. Klageren reklamerede derfor til den erhvervsdrivende og ønskede at hæve købet. Den erhvervsdrivende afviste dette og tilbød igen afhjælpning. Forbrugerklagenævnet udtalte, at det var op til den erhvervsdrivende at godtgøre, at der ikke havde været pligt til at tilbyde omlevering som følge af, at denne beføjelse ville påføre den erhvervsdrivende uforholdsmæssige omkostninger. Et flertal i nævnet fandt det under hensyntagen til pc’ens værdi og en sagkyndiges vurdering, godtgjort, at den erhvervsdrivende havde været berettiget til alene at tilbyde afhjælpning, da det ville have været uforholdsmæssigt for den erhvervsdrivende at foretage omlevering i forhold til afhjælpning. Henset til, at den erhvervsdrivende havde haft et afhjælpningsforsøg, som tog fire dage, fandt flertallet, at den erhvervsdrivendes yderligere tilbud om afhjælpning havde været berettiget. Et mindretal fandt klageren berettiget til at hæve.

Se også sag 69, refereret ovenfor.

Der findes herudover enkelte sager, der direkte angår art. 3, stk. 3, in fine, dvs. kravet om, at den beføjelse, der efter uforholdsmæssighedsvurderingen er den rigtige, skal gennemføres ,inden for rimelig tid og uden væsentlig ulempe for forbrugeren“. Disse sager kan formentlig give en indikation af, hvordan udtrykket „uden væsentlig ulempe for forbrugeren“ som kriterium i uforholdsmæssighedsvurderingen skal forstås. ${ }^{62}$

\footnotetext{
${ }^{62}$ Om den principielle forskel på de to regler, se prop. 2001/02:134, Bilag 9, bemærkningerne til
} $\S 26$. 


\section{Andre kriterier}

i. „Krone for krone“- princippet

I nogle tilfælde foretages tilsyneladende nærmest en „krone for krone“ sammenligning, hvor det afgørende er, om omkostningerne forbundet med omlevering væsentligt overstiger omkostningerne forbundet med afhjælpning.

Særlig udtalt er tendensen i svensk ret, hvor „krone for krone“- tilgangen til problemstillingen også synes at have en vis støtte i ordlyden af den svenske lovtekst, hvorefter der skal ses på, „... om den andra påföljden skulle kunna fullgöras till väsentligt lägre kostnad för säljaren“

85. Sag 2004-10-06; 2004-3797

Klageren havde købt en barnevogn til kr. 6.600. Efter en måned gik sømmene i stykker på flere steder. Klageren ønskede derfor at hæve købet, alternativt omlevering. Forhandleren afviste klagerens krav men tilbød afhjælpning. Det allmänna reklamationsnämnden fandt, at eftersom fejlen, der måtte anses som en mangel, kunne afhjælpes for et væsentligt lavere beløb end de omkostninger, som ville være forbundet med en omlevering, var forhandleren berettiget til at foretage afhjælpning. Klagerens krav om ophævelse, alternativt omlevering, blev derfor afvist.

88. Sag 2003-01-14; 2002-6334

Klageren havde købt et par sko til kr. 795 i september 2002. Kort tid efter løsnede skoenes fodsål sig. Klageren henvendte sig herefter til forhandleren og krævede omlevering. Forhandleren ville imidlertid afhjælpe fejlen. Reparation blev derfor foretaget. Klageren ønskede nu nævnets stillingtagen til, om købet kunne hæves, og om klageren kunne kræve erstatning. Det allmänna reklamationsnämnden fandt, at fejlen, som udgjorde en mangel, var udbedret på tilstrækkelig vis og til en væsentligt lavere omkostning for forhandleren, end en omlevering ville have forårsaget. Klagerens påstand om ophævelse og erstatning blev derfor afvist.

89. Sag 2003-12-19; 2003-7338

Klageren havde købt et par sko for kr. 3.095. Kort tid efter købet løsnede sålen på den venstre sko sig. Klageren henvendte sig derfor til forhandleren med krav om at få et par nye sko. Alternativt ønskede hun at hæve købet. Forhandleren tilbød afhjælpning. Det allmänna reklamationsnämnden fandt at fejlen, som var en mangel, let kunne afhjælpes på en tilfredsstillende måde, og at sådan afhjælpning kunne ske til en væsentligt lavere pris for forhandleren end prisen for en omlevering. Klageren måtte derfor acceptere forhandlerens tilbud om afhjælpning.

Afgørelserne er interessante, fordi det afgørende primært synes at være, om afhjælpning kan foretages for væsentlig lavere omkostninger end omlevering. Dette vil jo som regel være tilfældet. Spørgsmålet er derfor, om der ved konstateringen heraf i realiteten er fortaget den „uforholdsmæssighedsvurdering“, som kræves. Det er dog ikke alle svenske 
sager, der lader en omkostningssammenligning fremstå som det primære kriterium.

\section{Sag ARN 2003-4268}

En forbruger, A, købte i maj 2003 et modem for SEK 990. I slutningen af maj reklamerede A til den erhvervsdrivende, B, da modemet ikke virkede, som det skulle. A krævede omlevering eller alternativt at låne et andet modem i reparationsperioden. B afviste A's krav og modtog alene modemet med henblik på reparation. A købte herefter et andet modem og ønskede derefter at hæve købsaftalen med B. B afviste dette og bemærkede, at det var B, som kunne vælge misligholdelsesbeføjelse for A. Nævnet udtalte, at det fulgte af konsumentköplagen, at kræver en forbruger afhjælpning eller omlevering, kan sælgeren som hovedregel ikke afvise et krav om afhjælpning ved at tilbyde omlevering og omvendt. Kun såfremt forbrugerens krav om afhjælpning eller omlevering vil medføre uforholdsmæssige omkostninger for sælgeren, kan denne vælge en anden beføjelse. Da B i den konkrete sag ikke havde dokumenteret, at omlevering ville medføre uforholdsmæssige omkostninger, og da afhjælpningen havde medført væsentlig ulempe for A, var hun berettiget til at hæve købet.

I norsk ret har man i den ovenfor refererede sag (82) i Lagmannsretten imødegået tanken om omkostningssammenligning som det primære kriterium. Det siges her udtrykkeligt: „Det at det vil vœere vesentlig rimeligere [billigere] for selgeren å reparere enn å gi kunden et par nye støvletter, er et argument for selgerens ønske om reparasjon, men kan alene ikke være noe avgjørende moment“. ${ }^{63}$

\section{ii Miljømæssige hensyn}

Miljømæssige hensyn er blevet anført som et moment, der bør inddrages i uforholdsmæssighedsvurderingen. Tankegangen er, at afhjælpning - alt andet lige - er en mere miljøvenlig løsning end omlevering, idet et system, der primært er baseret på omlevering, vil indebære, at mange varer kasseres. Dette kan i sig selv have miljømæssige konsekvenser. Det samme gælder den merproduktion, der skal skabes for at leve op til omleveringskravene. Det miljømæssige hensyn blev fremdraget i den norske sag (82), refereret ovenfor. Lagmannsretten lagde til grund, at miljøhensynet ikke entydigt taler mod omlevering. Det udtales således:

„Isolert sett kan et generelt krav om omlevering innebære, at at flere ting skrottes enn det som er nødvendig. På den annen side vil en rett til omlevering i mangelstilfellene antagelig generelt sett føre til en større bevissthet til kvalitet blant forbrukere og blant produsenter/leverandører/selgere, hvilket igjen vil kunne føre til færre mangler ved gjenstander som det for øvrig også er en viss mulighet til å sikre gjenbruk av“.

\footnotetext{
${ }^{63}$ Se Lagmannsrettens afgørelse.
} 
For Høyesterett synes de miljømæssige aspekter imidlertid netop at have været afgørende, som det underliggende argument for fortolkningen af af omleveringsreglen. ${ }^{64}$ Miljømæssige hensyn ses ikke udtrykkeligt inddraget i sager fra de øvrige nordiske lande.

iii Hensynet til enkelhed i retssystemet

Hensynet til enkelhed i retssystemet nævnes i den norske sag (82), refereret ovenfor, som et yderligere kriterium i relation til forholdsmæssighedsvurderingen. Det fremhæves således i Laggmannsrettens afgørelse, at en meget kompliceret afvejningsregel i praksis kan komme til at få den effekt, at forbrugerens valgret i realiteten tilsidesættes. Dette taler efter Lagmannsrettens opfattelse i den konkrete sag for pålæggelse af omleveringspligt i overensstemmelse med hovedreglen. Synspunktet må formentlig forstås sådan, at man efter rettens opfattelse i tvivlstilfælde bør falde tilbage på hovedreglen, om valgfrihed for forbrugeren. Også Høyesteret inddrager hensynet til at fastslå en regel, der fører til færrest mulige tvister, men når frem til, at , det ikke er lett å forutse at det her er en forskjell som med noen vekt kan tale for den ene løsning frem for den anden“.

\subsubsection{Afhjcelpning som uforholdsmæessigt i forhold til omlevering}

Uforholdsmæssighedsvurderingen vedrører ikke alene omlevering set i forhold til afhjælpning, men også afhjælpning i forhold til omlevering. Er salgsgenstanden ikke en unika-genstand, vil forbrugeren i de fleste praktisk forekommende tilfælde kræve omlevering, i hvert fald hvor sælgeren ikke lykkes med sin afhjælpning i første eller andet forsøg. Det er således sjældent forekommende, at en forbruger afviser sælgerens tilbud om omlevering, men insisterer på afhjælpning, og der er tilsyneladende ingen praksis i de nordiske lande om dette spørgsmål.

Generelt kan man formentlig sige, at et krav om afhjælpning af en billig, masseproduceret salgsgenstand ofte vil medføre uforholdsmæssige omkostninger for sælgeren. Er der tale om en kostbar salgsgenstand, kan en sælger derimod alene afslå en forbrugers afhjælpningskrav, såfremt der foreligger vægtige grunde. Tilsvarende gælder for unika-genstande, hvor omlevering pr. definition ikke kan finde sted.

Nægter eller undlader sælgeren at foretage afhjælpning i en situation, hvor forbrugeren har ret hertil, kan forbrugeren i stedet hæve købet eller kræve omlevering, se hertil eksempelvis det norske forbruker-tvistutvalgs afgørelse i sag 83:

Forbrugeren havde købt en mobiltelefon til kr. 999. Ca. tre måneder efter købet begyndte telefonen at slukke sig selv. Forbrugeren indleverede telefonen til sælgeren, som efter det oplyste ikke informerede forbrugeren om, at han havde valgmulighed mellem afhjælpning og omlevering. Fejlen blev udbedret, men op-

\footnotetext{
${ }^{64}$ Smh. Hagstrøm, p. 203 verørende spørgsmålet om direktivet giver adgang til at inddrage miljømæssige hensyn.
} 
stod kort efter igen. Telefonen blev derfor atter indleveret, og sælgeren meddelte nu, at der var fugtskader i telefonen. Forbrukertvistutvalget fandt, at sælgeren ikke havde dokumenteret, at der forelå en fugtskade ved telefonen, og at der ikke var tilstrækkelige holdepunkter for at antage, at forbrugeren havde foretaget en brug af telefonen, som var udover det sædvanlige. Det konstateredes, at forbrugeren havde ret til at vælge mellem afhjælpning og omlevering, og da sælgeren havde nægtet at foretage afhjælpning, kunne forbrugeren hæve købet, idet manglen var væsentlig.

\subsubsection{Uforholdsmcessighedsvurderingen i andre sammenhæenge}

Efter art. 3. stk. 3 anses et krav om afhjælpning eller omlevering for uforholdsmæsssigt, hvis den pågældende beføjelse må anses for uforholdsmæssig sammenlignet med „den alternative beføjelse“. Det fremgår ikke, hvad der præcis menes med „den alternative beføjelse“. Det er klart, at bestemmelsen tager sigte på omlevering som alternativ til afhjælpning og afhjælpning som alternativ til omlevering. I de danske forarbejder er det imidlertid forudsat, at forholdsmæssighedsvurderingen også kan være relevant i forholdet mellem afhjælpningsbeføjelsen og en anden beføjelse end omlevering. ${ }^{65}$ Flere sager bekræfter denne fortolkning af reglen. For dansk ret kan henvises til følgende sag:

76. Sag 2003-650/7-151

Klageren havde købt nogle møbler til en samlet pris af kr. 43.865 den 23. april 2002. Den 1. oktober 2003 konstaterede klageren, at der var mange smårevner i møblerne og reklamerede herefter til den erhvervsdrivende. Da klageren ikke hørte noget fra den erhvervsdrivende, kontaktede klageren ham igen i april 2003 med krav om omlevering. Den erhvervsdrivende afviste reklamationen, og klageren indbragte herefter sagen for Forbrugerklagenævnet. Forbrugerklagenævnet udtalte, at det ikke var dokumenteret, at der var reklameret over mangler ved møblerne tidligere end i april 2003. Dette forhindrede imidlertid ikke klageren i at reklamere over fejlene, som efter en sagkyndigs vurdering skyldtes materiale- og fabrikationsfejl. Møblerne måtte derfor anses for mangelfulde, men da omlevering måtte anses for at påføre den erhvervsdrivende uforholdsmæssige omkostninger, bestemte nævnet, at klageren måtte lade sig nøje med et passende afslag på kr. 10.000 .

Nedenstående svenske sag illustrerer, at uforholdsmæssighedsvurderingen også kan være relevant i forholdet mellem afhjælpningsbeføjelsen og afslagsbeføjelsen.

87. Sag 2002-10-07; 2001-7983

Forbrugeren havde købt en sofagruppe for kr. 15.633 i november 1999. I foråret 2001 opdagede denne, at sofagruppens røde farve var blevet rosa. Hun klagede derfor til forhandleren med krav om, at sofaerne blev ombetrukket. Ifølge forbru-

${ }^{65}$ Betænkning 1403/2001, p. 113, ff, FT 2001-2002, Tillæg A, p. 331 ff., Lookofsky, Køb, 2. udgave, 2002. p. 267. 
geren gav forhandleren udtryk for, at man heller ikke syntes, at sofaerne så godt ud. Sofaerne skulle angiveligt have en levetid på 10 år. Forbrugeren havde behandlet sofaerne efter forskrifterne. Ved sagens behandling for nævnet afviste forhandleren forbrugerens krav om afhjælpning, idet forbrugeren efter forhandlerens opfattelse ikke havde behandlet sofaerne efter forskrifterne. Det allmänna reklamationsnämnden fandt, at der forelå en mangel. Da en ombetrækning imidlertid ville belaste forhandleren med uforholdsmæssige omkostninger, måtte forbrugeren lade sig nøje med et passende afslag på kr. 2.000 .

Det fremgår ikke af sagen, om omlevering var overvejet som alternativ beføjelse til afhjælpning, herunder om omlevering evt. i det konkrete tilfælde var udelukket. Afgørelsen viser, at der kan forekomme situationer, hvor såvel afhjælpning som omlevering må anses for uforholdsmæssige beføjelser. I disse tilfælde må der ifølge afgørelsen faldes tilbage på de øvrige beføjelser (afslag / (evt.)ophævelse), jf. herved direktivets art. 3, stk. 5, hvorefter forbrugeren kan kræve et afslag i prisen eller hæve købet, hvis han hverken er berettiget til at kræve afhjælpning eller omlevering. Et afslag kan i denne forstand komme til at fremstå som „den alternative beføjelse“ $\mathrm{i}$ henhold til stk. 3 .

I en anden sag fra det danske forbrugerklagenævn fandt man, at forbrugeren var berettiget til erstatning, fordi sælgerens ophævelse havde været uberettiget, eftersom det fremsatte krav om afhjælpning i en specieshandel ikke havde været uforholdsmæssigt.

80. Sag 2003-4012/7-300 En forbruger havde købt et fjernsyn som en demonstrationsmodel til $11.999 \mathrm{kr}$,
idet der blev indrømmet et prisnedslag på 14.000 kr. Fjernsynet gik efter kort tid i
stykker, og forbrugeren indleverede det til den erhvervsdrivende med anmodning
om afhjælpning af manglen. Den erhvervsdrivende meddelte senere, at det ikke
kunne lade sig gøre at afhjælpe, hvorfor forbrugeren i stedet kunne få sine penge
tilbage eller mod merbetaling få et tilsvarende fjernsyn i en ny serie. Forbrugeren
bad i stedet om at få fjernsynet tilbage, hvilket imidlertid ikke kunne lade sig gøre,
da den erhvervsdrivende havde kasseret fjernsynet og meddelte, at han havde hæ-
vet handlen. Nævnet fandt, at der var tale om et specieskøb, og at den erhvervs-
drivende, eftersom han havde kasseret fjernsynet, ikke havde godtgjort, at af-
hjælpning ville have påført ham uforholdsmæssige omkostninger i forhold til „en“
anden beføjelse. Et flertal i nævnet fandt herefter, at forbrugeren var berettiget til
erstatning for fjernsynets værdi, da der var handlet ansvarspådragende ved den
uretmæssige ophævelse og kasseringen af fjernsynet.

\subsubsection{Bevisbyrde}

Sælgeren kan efter samtlige nordiske købelove afvise en forbrugers krav om afhjælpning eller omlevering, hvis anvendelsen af beføjelsen vil påføre sælgeren uforholdsmæssige omkostninger. Det er op til sælgeren at gøre opmærksom på, at anvendelsen vil påføre ham uforholdsmæssige omkostninger, og det er derfor også ham, der skal dokumentere, at uforholdsmæssighedskriteriet er opfyldt. Dette fremgår af forarbejderne til 


\section{den danske købelov ${ }^{66}$. Det er endvidere fastslået i flere sager fra det dan- ske forbrugerklagenævn.}

\section{Sag 2002/4051/7-1312: køb af mobiltelefon}

En forbruger, A, havde købt en mobiltelefon, hvor displayet få måneder efter købet ophørte med at virke. Den erhvervsdrivende, B, reparerede displayet. Problemet opstod imidlertid atter, og A krævede derfor købet ophævet. B nægtede dette, men tilbød i stedet igen afhjælpning. Forbrugerklagenævnet konstaterede for det første, at der var tale om en væsentlig mangel, og at A derfor som udgangspunkt havde ret til at kræve købet ophævet. Herefter udtalte nævnet, at afværgelse af ophævelse forudsatte, at køberen havde fået valget mellem afhjælpning og omlevering, medmindre sælgeren kunne godtgøre, at den ene beføjelse ville være uforholdsmæssig, idet han i så fald ville kunne nøjes med at tilbyde den anden. Da sælgeren alene havde tilbudt afhjælpning og ikke havde godtgjort, at omlevering ville påføre ham uforholdsmæssige omkostninger, havde han ikke godtgjort, at tilbudet om afhjælpning var tilstrækkeligt til at afværge ophævelse. Køberen var derfor berettiget til at hæve

\section{Sag 4031/7-496}

Klageren havde købt en pc for kr. 10.216. Ca. tre uger efter købet ophørte pc'en med at virke. Klageren reklamerede og indleverede pc'en til den erhvervsdrivende. Efter 4 dage fik klageren pc'en retur. Pc'en var stadig ikke i orden. Klageren reklamerede derfor til den erhvervsdrivende og ønskede at hæve købet. Den erhvervsdrivende tilbød afhjælpning. Forbrugerklagenævnet udtalte, at det var op til den erhvervsdrivende at godtgøre, at der ikke havde været pligt til at tilbyde omlevering som følge af, at denne beføjelse ville påføre den erhvervsdrivende uforholdsmæssige omkostninger. Et flertal i nævnet fandt det, under hensyntagen til pc’ens værdi og en sagkyndigs vurdering, godtgjort, at den erhvervsdrivende havde været berettiget til alene at tilbyde afhjælpning, da det ville have været uforholdsmæssigt for den erhvervsdrivende at foretage omlevering i forhold til afhjælpning. Henset til, at den erhvervsdrivende havde haft et afhjælpningsforsøg, som tog fire dage, fandt flertallet, at den erhvervsdrivendes yderligere tilbud om afhjælpning havde været berettiget. Et mindretal fandt klageren berettiget til at hæve.

\section{Sag 4031/7-1146}

En forbruger klagede over en printers farveskrift, idet sort/hvide fotos nærmest blev udskrevet i farve, mens den blå farve slet ikke blev udskrevet. Der var enighed om, at der forelå en mangel, og forbrugeren krævede omlevering. Spørgsmålet var, om sælgeren kunne afvise dette under henvisning til en uforholdsmæssighedsbetragtning. Forbrugerklagenævnet fastslog her, at udgangspunktet er valgret for forbrugeren, og at det er sælgeren, der har bevisbyrden for, at der foreligger uforholdsmæssighed. Dernæst fastslog man, at det forhold, at en mangel lader sig afhjælpe let eller billigt ikke uden videre er tilstrækkeligt til, at et krav om omlevering kan anses for uforholdsmæssigt, ,idet de ved vurderingen tillige må tages hensyn til forbrugerens interesse i den valgte beføjelse, ligesom det vil skulle indgå i vurderingen, hvilke muligheder sælgeren har med hensyn til at reparere og sælge den ombyttede genstand til anden side som lettere brugt“. Nævnet lagde

\footnotetext{
${ }^{66}$ Jf. FT 2001-2002, tillæg A, s. 329.
} 
endvidere til grund, at merudgiften ved omlevering frem for reparation måtte beregnes som forskellen mellem indkøbsprisen på 706,76 kr. for en ny printer og videresalgsprisen for den reparerede printer. Da klageren havde købt en genstand, som han dagligt havde brug for, fandtes et omleveringskrav ud fra en samlet vurdering ikke uforholdsmæssigt.

Dokumentationskravet kan opfyldes på forskellig vis. Sælgeren kan eksempelvis fremlægge dokumentation for, at omkostningerne forbundet med opfyldelse af forbrugerens krav om afhjælpning af en mangel i væsentlig grad vil overstige omkostningerne til omlevering. I så fald vil sælgeren som udgangspunkt have ret til at foretage omlevering i stedet for afhjælpning. Dokumentationen kan bestå i erklæringer udarbejdet af uafhængige tredjemænd, men der er intet principielt til hinder for, at sælgeren fremlægger egne erklæringer. Bevisværdien heraf vil dog selvsagt efter omstændighederne være begrænset.

\subsubsection{Oplysningspligt (?)}

Direktivet og de nordiske love fastslår, at forbrugeren indledningsvis har valgretten mellem afhjælpning og omlevering. Man kan rejse spørgsmålet, om sælgeren skal oplyse forbrugeren om dennes ret til at vælge mellem afhjælpning og omlevering. Der er ikke taget udtrykkelig stilling hertil hverken i direktivet eller i de nordiske landes lovgivning. Spørgsmålet berøres i to sager fra det danske forbrugerklagenævn.

\section{Sag $2002 / 4051 / 7-1312$}

En forbruger, A, havde købt en mobiltelefon, hvor displayet få måneder efter købet ophørte med at virke. Den erhvervsdrivende, B, reparerede displayet. Problemet opstod imidlertid atter, og A krævede derfor købet ophævet. B nægtede dette, men tilbød i stedet igen afhjælpning. Forbrugerklagenævnet konstaterede for det første, at der var tale om en væsentlig mangel, og at A derfor som udgangspunkt havde ret til at kræve købet ophævet. Herefter udtalte nævnet, at afværgelse af ophævelse forudsatte, at køberen havde fået valget mellem afhjælpning og omlevering, medmindre sælgeren kunne godtgøre, at den ene beføjelse ville være uforholdsmæssig, idet han i så fald ville kunne nøjes med at tilbyde den anden. Da sælgeren alene havde tilbudt afhjæelpning og ikke havde godtgjort, at omlevering ville påføre ham uforholdsmæssige omkostninger, havde han ikke godtgjort, at tilbudet om afhjælpning var tilstrækkeligt til at afværge ophævelse. Køberen var derfor berettiget til at hæve.

68. Sag 2003-4051/7-260

En forbruger, A, havde købt en mobiltelefon. Telefonen kunne ikke indlæse SIM kortet. Den erhvervsdrivende, B, forsøgte afhjælpning ved en reparation, som tog 14 dage, men telefonen ville fortsat ikke indlæse SIM kortet. Forbrugeren hævede derfor købet. B nægtede at efterkomme A’s krav om ophævelse af købet og tilbød i stedet endnu et afhjælpningsforsøg. Forbrugerklagenævnet fandt, at der var tale om en væsentlig mangel, og da B ikke havde godtgjort, at manglen ikke kunne have været afhjulpet allerede i første forsøg, hvortil kom, at B alene havde tilbudt 
afhjælpning og ikke omlevering, havde A ikke pligt til at tåle endnu et afhjælpningsforsøg, og købet kunne derfor hæves.

Fælles for de to sager er, at sælgeren havde foretaget et afhjælpningsforsøg, som imidlertid ikke afhjalp manglen endegyldigt, og at forbrugeren herefter ønskede at hæve købet. Det fastslås her, at da sælgeren ikke havde givet forbrugeren valget mellem afhjælpning eller omlevering (sag 72), henholdsvis da sælgeren alene havde tilbudt afhjælpning og ikke omlevering (sag 68), var forbrugeren berettiget til at hæve købet. Afgørelserne må betyde, at mødes sælgeren med et krav om ophævelse, som søges afværget ved, at sælgeren alene tilbyder forbrugeren afhjælpning (eller omlevering), uden at han senere kan godtgøre, at den anden beføjelse ikke var relevant, fordi den enten var umulig eller uforholdsmæssig, da vil forbrugeren kan have ret til at ophæve købet, hvis de sædvanlige betingelser herfor er opfyldt (væsentlig mangel mv.). ${ }^{67}$

\subsection{Umulighed i praksis}

To sager fra det danske forbrugerklagenævn vedrører kriteriet „umulighed“ i relation til beføjelserne afhjælpning/omlevering. Den første sag vedrørte et specieskøb.

70. Sag 2003-642/7-23: forlængelse af armbånd

En forbruger, A, fik forlænget et armbånd ved købsaftalens indgåelse. Kort tid efter knækkede armbåndet tre steder. Forbrugerklagenævnet konstaterede, at der som følge af forlængelsen var tale om et specieskøb. Omlevering var derfor ikke mulig. Den erhvervsdrivende, B, kunne afværge A's krav om ophævelse ved at foretage afhjælpning inden rimelig tid.

Den anden sag vedrørte et genuskøb.

71. Sag unummereret

En forbruger, A, købte i juli 2002 en harddisk til DKR 937. Efter et år virkede harddisken ikke længere efter hensigten, og A indleverede den derfor til den erhvervsdrivende, B. 11/2 måned efter indleveringen meddelte B A, at harddisken ikke kunne repareres. B ville foretage ombytning til en anden model fra samme producent med samme specifikationer, idet den købte model ikke længere blev produceret eller alternativt give $\mathrm{A}$ et tilgodebevis på værdien af denne svarende til ca. halvdelen af den oprindelige købesum. A ønskede ombytning til præcis samme model. Da dette ikke blev imødekommet, hævede A købet. Forbrugerklagenævnet

${ }^{67}$ Henvender forbrugeren sig blot til sælgeren med en reklamation, uden at specificere hvad sælgeren skal foretage sig i anledning af indsigelsen, må det antages, at sælgeren har ret til at vælge frit mellem afhjælpning, omlevering, et passen-de vederlag eller ophævelse. Nægter forbrugeren imidlertid at acceptere sælgerens forslag, idet denne for eksempel kræver omlevering i stedet for sælgerens tilbud om afhjælpning, finder de almindelige regler anvendelse. Sælgeren har herefter pligt til at opfylde forbrugerens krav om omlevering, såfremt de almindelige betingelser herfor er opfyldt. 
konstaterede - på baggrund af en sagkyndig erklæring - at den harddisk, B havde tilbudt at bytte med, var en ny udgave, som ikke havde helt de samme specifikationer som den først leverede harddisk, men at forskellene var så små, at det ikke ville kunne registreres under normal brug. B fandtes derfor at have tilbudt at ombytte harddisken med en ny harddisk, som reelt var overensstemmende med, hvad A ifølge købsaftalen og de ved købet foreliggende omstændigheder havde været berettiget til at forvente af den købte genstand. A var derfor ikke berettiget til at hæve købet.

\subsection{Komparativ sammenfatning}

Reguleringen af uforholdsmæssighedskriteriet i direktivets art. 3, stk. 3, er i vid udstrækning implementeret identisk i de nordiske lande. Af forskelle som bør fremhæves, kan for det første nævnes den sproglige fremhævelse i den norske og islandske lovtekst af forbrugerens valgret og for det andet det lovfæstede „fjerde kriterium“ i den svenske lovtekst, hvorefter der ved uforholdsmæssighedsvurderingen skal tages hensyn til, om den alternative beføjelse vil kunne gennemføres med væsentlig lavere omkostninger end den valgte beføjelse. Disse forskelle i detaljerne synes i et vist omfang at blive afspejlet i praksis.

Der er ingen praksis om den situation, hvor forbrugeren ønsker afhjælpning frem for omlevering. Det følgende tager derfor sigte på den omvendte situation, hvor forbrugeren ønsker omlevering frem for afhjælpning.

I relation til det overordnede kriterium, hvorefter der skal ses på om omkostningerne forbundet med omlevering er uforholdsmæssige i forhold til omkostningerne forbundet med afhjælpning, er der dansk og norsk praksis for, at omkostningerne ved omlevering som udgangspunkt skal fastsættes til varens indkøbspris for sælgeren. Det er tilsyneladende alene i dansk forbrugerklagenævnspraksis, man er gået videre og har betonet, at det også kan have betydning, om den pågældende vare vil kun genanvendes som let brugt salgsobjekt af sælgeren.

I relation til kriteriet ,genstandens værdi“ er der dansk og norsk praksis for, at dette skal forstås sådan, at lav værdi som regel taler for omlevering. Dette udgangspunkt har også støtte i lovforarbejder. Lav værdi taler dog mod omlevering, hvis varens værdi er lav på grund af forbrugerens brug af den.

For så vidt angår kriteriet „manglens betydning“ er det i norsk ret fastslået, at der herved skal ses på, om manglen kan karakteriseres som væsentlig for varens funktion.

Hvad angår kriteriet „uden væsentlig ulempe for forbrugeren“ fremgår det af dansk og norsk praksis, at der herved må henses til, hvor hurtigt afhjælpning kan ske, om varen efter afhjælpning vil lide af andre skavanker end rent kosmetiske, og om forbrugeren i det konkrete tilfælde har særlig vanskeligt ved at undvære den pågældende genstand. 
Det fremgår endvidere af praksis, at man udover direktivets tre kriterier også anvender andre kriterier ved vurderingen af, om omleveringsbeføjelsen er „uforholdsmæssig“.

Det er et særkende for svensk ret, at man tilsyneladende lægger afgørende vægt på, om gennemførelsen af omlevering vil være „væsentlig mere omkostningsfuld“ for sælgeren end afhjælpning (,krone for krone“princippet). Når dette kriterium anvendes i svensk ret og ikke i de andre nordiske lande, må det antages at afspejle, at dette kriterium netop udtrykkeligt er skrevet ind i den svenske lovtekst. Det er interessant at bemærke, at man i den norske Lagmannsretts dom udtrykkeligt har taget afstand fra en meget håndfast anvendelse af dette kriterium. Billedet er således umiddelbart, at det formentlig vil være noget sværere at komme igennem med et omleveringskrav i svensk ret end i norsk ret.

Det er i øvrigt et særkende for norsk ret, at såvel lovforarbejder som domstolsafgørelserne har inddraget betydningen af et miljømæssigt hensyn. Det må dog anses for noget uklart, hvilken betydning dette hensyn spiller, herunder om miljøhensynet entydigt taler mod omlevering, og om der evt. bør sondres mellem forskellige varekategorier og evt. mellem omlevering af en enkelt vare og hele vareserier.

Den nordiske praksis illustrerer i øvrigt, at uforholdsmæssighedsvurderingen kan være relevant ikke blot i forholdet mellem afhjælpningsbeføjelsen og omleveringsbeføjelsen men også f.eks. i forholdet mellem afhjælpning og afslag eller afhjælpning og ophævelse.

Det synes at være den almindelige antagelse, at det er sælgeren, der har bevisbyrden for, at en beføjelse, som forbrugeren ønsker at anvende, er uforholdsmæssig. Dette afspejler, at direktivets hovedregel om, at det er forbrugeren, der har valgretten, slår igennem også i de retssystemer, hvor man ikke sprogligt har fremhævet dette i lovteksten. Dette ses også i dansk forbrugerklagenævnspraksis, hvor det - selv om hovedreglen ikke sprogligt er fremhævet i lovteksten - i præmisserne til afgørelserne ofte fastslås, at forbrugeren har valgretten.

Hverken direktivet eller de nordiske lovbestemmelser fastslår, at sælgeren har pligt til at oplyse forbrugeren om dennes valgret i henhold til reglerne. Alligevel viser praksis, at manglende oplysning fra sælgers side kan have skadevirkninger for denne.

\subsection{Kendskab til reglen i branchen}

Som beskrevet ovenfor var det overordnede formål med lovændringerne som følge af direktivet at forbedre forbrugerens retstilling. Forbedringen ligger primært $\mathrm{i}$, at forbrugeren har valgretten mellem afhjælpning og omlevering. Herved er forbrugerens adgang til at kræve omlevering blevet udvidet i forhold til tidligere. Forbedringen afspejles i praksis ved, at uforholdsmæssighedsvurderingen foretages på en sådan måde, at omleve- 
ring ikke kan afvises af den erhvervsdrivende blot under henvisning til, at man foretrækker afhjælpning, eller at omlevering vil være mere omkostningsfuldt for sælgeren end afhjælpning. Der skal foretages en samlet vurdering af, om omlevering vil være uforholdsmæessigt meget mere omkostningsfuldt for sælgeren end afhjælpning. Selv om denne uforholdsmæssighedsvurdering foretages med vægtning af lidt forskellige kriterier i de forskellige nordiske lande, er det overordnede billede, at de retsanvendende myndigheder er opmærksomme på, at forholdsmæssighedsvurderingen skal afspejle den realitetsændring til forbrugerens fordel, som var formålet med de nye lovregler.

Ideelt set burde denne forståelse af reglerne også komme til udtryk i den måde reglerne praktiseres på i branchen. I CBS-undersøgelsen fra 2005 er dette spørgsmål blevet undersøgt, for så vidt angår dansk ret.

Det indsendte spørgeskema indeholdt således følgende spørgsmål til den erhvervsdrivende (p. 32):

„Har de nye regler medført, at De i nogen tilfælde bytter en vare, hvor de tidligere ville have repareret den?“

Hele $67 \%$ af de adspurgte svarede hertil „nej“, og $2 \%$ svarede endda „tværtimod“. De sidste 31 \% af de adspurgte besvarede spørgsmålet positivt, men med varierende intensitet. Af de sidste $31 \%$ svarede således $13 \%$ „,sjældent“, 16 \% ,ja, i nogle tilfælde“ og $2 \%$,ja, i mange tilfælde“.

Det kan således konstateres, at reglerne for godt 2/3 af de adspurgte skønnes ikke at have haft nogen effekt, mens de for næsten 1/3 af de adspurgte skønnes at have haft den ønskede effekt omend med varierende intensitet.

Spørgeskemaet søgte også at belyse forbrugeradfærden med følgende spørgsmål til den erhvervsdrivende (p. 35):

\footnotetext{
„Er der flere kunder end tidligere, der kræver at få en mangelfuld vare byttet med en ny?“

Til dette svarede $47 \%$ nej, mens 53 \% svarede spørgsmålet bekræftende men med varierende intensitet, idet hele 31 \% svarede „sjældent“.
}

Resultaterne af undersøgelsen kan give anledning til at rejse spørgsmålet, om den grundlæggende ændring, der består i som udgangspunkt at indrømme forbrugeren valgretten mellem afhjælpning og omlevering, er kommet tilstrækkeligt tydeligt til udtryk i lovteksten. Der foreligger hverken tilsvarende undersøgelser fra norsk eller islandsk ret, der kan belyse spørgsmålet, om den sproglige fremhævelse af valgretten i disse landes lovtekster har påvirket brancheadfærden i højere grad end de danske regler. 


\section{Undersøgelsesgebyrer}

\subsection{Emnets relation til forbrugerkøbsdirektivets regler}

Det er en direkte følge af forbrugerkøbsdirektivet, at er den leverede salgsgenstand mangelfuld, har forbrugeren krav på omkostningsfri afhjælpning. Dette fremgår af art. 3, stk. 2, der har følgende ordlyd:

\footnotetext{
„I tilfælde af manglende overensstemmelse har forbrugeren ret til at få forbrugsvaren bragt i overensstemmelse med købsaftalen ved gratis afhjælpning eller omlevering i overensstemmelse med stk. 3 eller til et passende afslag i prisen, eller til at hæve købet med hensyn til de leverede varer, jf. stk. 5 og $6 . “$
}

Der er således ikke adgang til for den erhvervsdrivende at afkræve forbrugeren et vederlag for at afhjælpe en mangel. Der er heller ikke hjemmel til, at forbrugeren kan pålægges at betale et gebyr for undersøgelse af salgsgenstanden, såfremt undersøgelsen resulterer $i$, at der findes en mangel, idet undersøgelsen i så fald må betragtes som en del af afhjælpningen. Har forbrugeren betalt et sådant gebyr ved salgsgenstandens indlevering til den erhvervsdrivende, må gebyret tilbagebetales. Direktivets krav om omkostningsfri afhjælpning af mangler indebærer således, at det kun er i tilfælde, hvor den foretagne undersøgelse resulterer i, at der ikke findes en mangel ved det købte, at betalingen af et gebyr kan komme på tale. Forbrugerkøbsdirektivet tager ikke stilling til, om den erhvervsdrivende må afkræve forbrugeren et gebyr i disse tilfælde. Det er derfor overladt til de enkelte medlemslande selv at træffe afgørelse herom. På nordisk plan har Norge og Island valgt at regulere spørgsmålet direkte i loven, hvorimod man i Danmark, Finland og Sverige alene støtter sig til praksis og almindelige aftaleretlige principper, jf. i det følgende.

\subsection{Reguleringen af adgangen til at opkræve undersøgelsesgebyrer i de enkelte nordiske lande}

\subsubsection{Lovregler i Norge og på Island}

Spørgsmålet om den erhvervsdrivendes adgang til at opkræve gebyr for undersøgelser af salgsgenstanden med henblik på at få konstateret, om genstanden lider af en mangel, er lovreguleret i såvel Norge som Island.

Den norske lov om forbrugerkøb § 30, stk. 4, har følgende ordlyd: 
„Dersom det ikke foreligger en mangel, kan selgeren bare kreve betaling for undersøkelser som har vært nødvendige for å avgjøre om det foreligger en mangel, og betaling for reparasjon av tingen, dersom selgeren har gjort forbrukeren uttrykkelig oppmerksom på at han eller hun selv må dekke slike kostnader.“

Den islandske lov om forbrugerkøb § 30, stk. 4, har følgende ordlyd (uautoriseret dansk oversættelse):

„Viser det sig, at salgsgenstanden ikke lider af en mangel, kan sælgeren kun kræve betaling for de undersøgelser, som var fornødne for at kunne fastslå, hvorvidt salgsgenstanden var behæftet med mangel, og betaling for afhjælpning af salgsgenstanden, såfremt sælgeren har gjort forbrugeren det klart, at denne selv må bære de omtalte omkostninger.“

Begge bestemmelser bekræfter udtrykkeligt det ovenfor beskrevne udgangspunkt, hvorefter det kun er i tilfælde, hvor salgsgenstanden ikke lider af en mangel, at der kan kræves undersøgelsesgebyr. Endvidere fastslås, at vilkåret om gebyret skal være vedtaget mellem parterne (nærmere herom nedenfor under 6.3.2).

\subsubsection{Almindelige principper - retstilstanden i Danmark, Finland og Sverige}

Spørgsmålet om den erhvervsdrivendes adgang til at opkræve gebyr for undersøgelser af salgsgenstanden med henblik på at få konstateret, om genstanden lider af en mangel, er som anført, hverken lovreguleret i Danmark, Sverige eller Finland. Der må derfor i disse lande faldes tilbage på almindelige aftaleretlige principper ved afgørelsen af, i hvilket omfang der kan kræves gebyr. Udgangspunktet må således tages i princippet om aftalefrihed, således at et gebyr frit kan aftales mellem parterne. Princippet om aftalefrihed er dog, som ovenfor nævnt, indskrænket til at angå de tilfælde, hvor genstanden ikke er mangelfuld. Herudover gælder de almindelige aftaleretlige ugyldighedsgrunde.

\subsubsection{Sammenfattende om betingelserne for at krceve gebyr}

På baggrund af ovenstående kan konkluderes, at der generelt i de undersøgte retssystemer er en række betingelser, der skal være opfyldt, for at der kan kræves undersøgelsesgebyr. Det er for det første et krav, at varen ikke er mangelfuld. Dernæst skal vilkåret om betaling af undersøgelsesgebyr være aftalt mellem parterne inden undersøgelsen. Endelig må aftalevilkåret ikke være urimeligt. Det er som udgangspunkt sælgeren, der har bevisbyrden for, at han er berettiget til at kræve et gebyr og dermed for, at ovennævnte betingelser er opfyldt. 


\subsection{Praksis}

\subsubsection{Varen må ikke vcere mangelfuld - bevisbyrdeforhold}

\subsubsection{Dansk ret}

I dansk ret fremgår det tydeligt af praksis, at det i relation til spørgsmålet om undersøgelsesgebyrer er sælgeren, der har bevisbyrden for, at varen ikke var mangelfuld. To afgørelser illustrerer princippets anvendelse uden for garantitilfcelde.

\section{Sag 2002-4031/7-2198}

En forbruger, A, havde købt et motherboard, som han efter nogen tid sendte til den erhvervsdrivende, B, idet der angiveligt var fejl på boarded. Da A ønskede at afhente motherboarded, krævede B et undersøgelsesgebyr, idet han ikke havde fundet nogen fejl ved varen. A nægtede at betale gebyret og kunne herefter ikke få udleveret motherboarded. A indbragte herefter sagen for Forbrugerklagenævnet. Forbrugerklagenævnet fandt ikke, at A havde godtgjort, at boarded var mangelfuldt, hvorfor A ikke kunne gøre mangelsindsigelser gældende. I relation til gebyret udtalte nævnet, at vil en erhvervsdrivende påberåbe sig at være berettiget til et undersøgelsesgebyr, må den erhvervsdrivende godtgøre, at han er berettiget til et sådant gebyr. Lider en salgsgenstand af mangler, som forbrugeren kan kræve afhjulpet, er den erhvervsdrivende forpligtet til vederlagsfrit at tage stilling til reklamationen og udføre afhjælpningen gratis. Skal den erhvervsdrivende kunne kræve et undersøgelsesgebyr, må det derfor påhvile scelgeren at godtgøre, at der ikke foreligger mangler ved det solgte, og at det i øvrigt er udtrykkeligt aftalt med forbrugeren, at der i denne situation skal betales et undersøgelsesgebyr, da forbrugeren jo ved at kræve afhjclpning ikke har bestilt en ydelse, som der skal betales for. I den konkrete sag havde B hverken bevist, at motherboardet ved leveringen var uden mangler, eller at det var aftalt med A, at denne skulle betale et testgebyr, såfremt B ikke kunne konstatere mangler ved det solgte. Nævnet fandt derfor, at der herefter ikke kunne gives B medhold i, at det havde været berettiget at afkræve A et undersøgelsesgebyr. B var som følge heraf ikke berettiget til at betinge udleveringen af motherboardet til A af, at denne betalte et undersøgelsesgebyr på 250 kr. B’s uberettigede tilbageholdelse af motherboardet fandtes endvidere at udgøre en hævebegrundende misligholdelse af købet, og nævnet gav som følge heraf A medhold i dennes krav om at få købesummen på kr. 1.000 refunderet.

I denne sag var det således hverken muligt for forbrugeren at godtgøre, at varen var mangelfuld, eller for den erhvervsdrivende at godtgøre, at den ikke var det, hvorfor resultatet blev, at der hverken kunne gøres misligholdelsesbeføjelser gældende eller kræves gebyr. Noget anderledes var forholdene i den følgende sag:

96. Sag 2003-4021/7-15

Kort tid efter køb af et digitalkamera forsøgte en forbruger, A, at opdatere kameraets firmware via producenten, B's, hjemmeside. Opdateringen mislykkedes, og kameraet fungerede derefter ikke. A indleverede kameraet til sælgeren, C, der konstaterede, at kameraets hovedkort var blevet beskadiget i forbindelse med for- 
søget på opdatering, og at reparationen ville koste kr. 3.061. A afviste at betale, idet han mente, at reparationen burde udføres gratis, da B burde have oplyst tydeligere om de risici, der var ved opdatering. A blev derefter opkrævet et undersøgelsesgebyr på kr. 744, som han betalte under protest. Forbrugerklagenævnet fandt på baggrund af sagens oplysninger herunder den sagkyndiges erklæring ikke, at skaderne skyldtes mangler ved kameraet, som var til stede på leveringstidspunktet. Der kunne derfor ikke gives A medhold i hans krav mod indklagede om gratis afhjælpning. Hvad angik det omtvistede undersøgelsesgebyr, påhvilede det C at godtgøre, at han var berettiget til et sådant gebyr. Nævnet udtalte i den forbindelse, at lider en salgsgenstand af mangler, som køberen kan kræve afhjulpet, er sælgeren forpligtet til vederlagsfrit at tage stilling til reklamationen og udføre afhjælpning gratis. Skal scelgeren kunne kræve et undersøgelsesgebyr, må det derfor påhvile scelgeren at godtgøre, at der ikke er mangler ved det solgte. Det må derudover påhvile scelgeren at godtgøre, at det udtrykkeligt er aftalt med forbrugeren, at der i denne situation skal betales et undersøgelsesgebyr, da forbrugeren jo ved at kræve afhjcelpning ikke har bestilt en ydelse, som der skal betales for. C havde ikke bevist, at det var aftalt med klageren, at denne skulle betale et undersøgelsesgebyr, såfremt C ikke kunne konstatere mangler ved det solgte, og A kunne derfor kræve det opkrævede gebyr på kr. 744 tilbagebetalt af sælgeren. ${ }^{68}$

I denne sag fandt nævnet på baggrund af den sagkyndige erklæring ikke, at skaderne skyldtes mangler. Da den erhvervsdrivende imidlertid ikke havde bevist, at der var indgået aftale om undersøgelsesgebyr, kunne dette ikke kræves.

Kravene til sælgers bevis for, at der foreligger et forhold, som han ikke er ansvarlig for, skærpes, når der er afgivet en garanti. I dansk ret har forbrugerklagenævnet således udtalt, at har den erhvervsdrivende givet forbrugeren en garanti, kan han alene afkræve forbrugeren et undersøgelsesgebyr, hvis det kan bebrejdes forbrugeren, at denne uden grund har indleveret salgsgenstanden til reparation, eller at der er repareret skader, som kunden selv er ansvarlig for. Indleverer forbrugeren salgsgenstanden til undersøgelse i garantiperioden, og kan der ikke findes en mangel omfattet af garantien, er det med andre ord ikke tilstrækkeligt for, at den erhvervsdrivende kan opkræve et gebyr, at dette er aftalt med forbrugeren. Der må yderligere være noget at bebrejde forbrugeren. Princippet kommer til udtryk i de følgende sager:

\footnotetext{
${ }^{68}$ For så vidt angår A’s forsøg på at opdatere kameraets firmware, fremgik det af den sagkyndiges oplysninger, at kun en lille del af opgraderingsfilen var kopieret til A's CF-kort. Det fremgik endvidere af oplysningerne fra B’s hjemmeside, at $\mathrm{B}$ har været bekendt med, at nogle kunder på tidspunktet, hvor A har forsøgt opdatering, havde haft problemer med at fuldføre opdatering af firmware, idet det for disse var umuligt at kopiere firmwaret korrekt til CF-kortet. Det fremgik dernæst, at B i maj 2002 forbedrede opdateringsprogrammet, således at driftsikkerheden i forbindelse med opdatering blev forbedret. Nævnet lagde på denne baggrund til grund, at A's kamera var blevet beskadiget under opdateringen som følge af manglende driftsikkerhed ved B's opdateringsprogram, som således må antages at have været fejlbehæftet. Selv om B på sin hjemmeside havde taget forbehold for, at opdatering af firmware i kameraet skete for kundens egen regning og risiko, indebar dette ikke, at A også accepterede at bære risikoen for tab som følge af, at hjemmesidens opdateringsprogram var fejlbehæftet. B var derfor erstatningsansvarlig over for A for det tab, der derved blev påført ham. Erstatningen fastsattes til kr. 3.061 svarende til den anslåede afhjælpningspris.
} 


\section{Sag 1999-4031/7-1175:}

En forbruger, A, indleverede sin computer til reparation inden for garantiperioden. Fejlbeskrivelsen på den erhvervsdrivende, B’s, serviceseddel angav: „Fryser i Windows“. B’s værksted kunne ikke finde nogen fejl og krævede derfor 625 kr. for undersøgelsen. A bestred kravets berettigelse. Nævnet udtalte, at udtrykket garanti kun må anvendes i forbrugerforhold om erklæringer, som giver modtageren en væsentlig bedre retsstilling end den, forbrugeren har efter lovgivningen. Et garantitilsagn som det, der forelå i denne sag, måtte fortolkes som en garanti mod funktionssvigt i et år efter overgivelsen. A havde derfor været berettiget til at forvente, at B i tilfælde af funktionssvigt i garantiperioden ville udføre den nødvendige fejlfinding og reparation gratis, medmindre han kunne godtgøre, at funktionssvigtet skyldtes uhensigtsmæssig brug eller andre forhold, som ikke var omfattet af garantien. Det var derfor ikke foreneligt med B's garantitilsagn at kræve vederlag for enhver forgæves fejlfinding. Nævnet bemærkede også, at B for at kunne løfte sin bevisbyrde selv har en væsentlig interesse $\mathrm{i}$ at foretage den nødvendige fejlfinding og bevissikring. Derfor var det ncevnets opfattelse, at det er en betingelse for at krceve betaling for forgceves fejlfinding eller for en udført reparation i garantiperioden, at garantigiveren kan godtgøre, enten at det kan bebrejdes køberen, at denne uden grund har indleveret salgsgenstanden til reparation, eller at der er repareret skader, kunden selv er ansvarlig for. Det må derudover krceves, at garantigiveren på forhånd har sikret sig, at kunden er bekendt med, at han risikerer at skulle betale et ncermere angivet beløb, og at kunden har accepteret dette. Det forhold, at undersøgelsen ikke viste fejl ved computeren, udelukkede efter nævnets opfattelse ikke, at A havde været udsat for den beskrevne fejl. Det var derfor ikke godtgjort, at det kunne bebrejdes $\mathrm{A}$, at han havde indleveret computeren til reparation i henhold til garantien. Nævnet konkluderede derfor, at B ikke havde krav på et undersøgelsesgebyr.

\section{Sag 2000-4031/7-1379:}

Forbrugeren havde købt en cd-recorder. Den erhvervsdrivende havde givet et års garanti mod fabrikations- og materialefejl. Forbrugeren reklamerede inden for garantiperioden over, at recorderen ikke kunne skrive cd'er. Den erhvervsdrivende kunne imidlertid ikke finde fejlen og opkrævede A 249 kr. for undersøgelsen (eftersynet). Forbrugeren bestred kravets berettigelse, krævede købet ophævet og indbragte sagen for Forbrugerklagenævnet. Nævnets sagkyndige havde under sagen heller ikke kunnet konstatere funktionssvigt, men denne udtalte under nævnsmødet, at det ikke kunne udelukkes, at cd-recorderen var behæftet med en periodisk fejl. Nævnet udtalte herefter, at vil en erhvervsdrivende i en garantiperiode kræve betaling for forgeves fejlfinding, må han godtgøre, at det kan bebrejdes forbrugeren, at denne uden grund har indleveret salgsgenstanden til reparation, ligesom det må kræves, at den erhvervsdrivende på forhånd har sikret sig, at kunden er bekendt med, at han risikerer at skulle betale et nærmere angivet beløb, og at forbrugeren har accepteret dette. Det forhold, at hverken den erhvervsdrivende eller den sagkyndige har kunnet finde fejl ved computeren, udelukker ikke, at klageren kan have været udsat for et funktionssvigt af periodisk karakter. Det er derfor ikke godtgjort, at det kan bebrejdes klageren, at han har indleveret computeren til reparation i henhold til garantien.

Det følger af sagerne, at sælgeren i garantitilfælde kun kan kæve et aftalt undersøgelsesgebyr, hvis han kan godtgøre, at produktet har været udsat 
for uhensigtsmæssig brug af forbrugeren, eller at denne reelt ikke har været udsat for det funktionssvigt, som forbrugeren hævder (idet det i så fald kan bebrejdes forbrugeren, at denne reklamerer over varen). Det er ikke tilstrækkeligt, at der ikke af nævnets sagkyndige på undersøgelsestidspunktet kan konstateres fejl ved produktet, idet dette ikke udelukker, at der kan have optrådt en „,periodisk fejl“. Sælgerens bevisbyrde er således væsentligt skærpet i forhold til de tilfælde, hvor der ikke er givet garanti.

\title{
6.3.1.2 Svensk ret
}

I svensk ret opstilles tilsyneladende ikke nogen særlig bevisbyrderegel i relation til spørgsmålet om, hvorvidt den pågældende genstand lider af en mangel. Uden for garantitilfælde illustreres dette af nedenstående sag:

\section{Sag 2002-5388}

\begin{abstract}
Klageren havde købt en printer i februar 2000. Hun fik et års garanti. Printeren blev indleveret til reparation i marts 2001, altså efter garantiperiodens udløb. For så vidt angik mangelsspørgsmålet udtalte nævnet, at det som udgangspunkt er køberen, der har bevisbyrden for, at varen var mangelfuld. Under henvisning til NJA 1991 s. 481, fastslås endvidere, at kravet er, ,at köparen skall visa att det är klart mer sannolikt att felet är ursprungligt än att det har uppstått till följd av en omständighet som säljaren inte har att svara för“. Under anvendelse af denne regel vurderede man i den konkrete sag, at forbrugeren ikke havde løftet bevisbyrden og dermed ikke havde krav på afhjælpning. For så vidt angik spørgsmålet om undersøgelsesgebyr udtalte nævnet i forlængelse heraf, at eftersom det ikke var dokumenteret, at klageren var blevet oplyst om, at der ville blive opkrævet et undersøgelsesgebyr, skulle forhandleren tilbagebetale gebyret til klageren. (Fejlens karakter er ikke oplyst og der gives ingen oplysninger om et evt. indleveringsbevis.).
\end{abstract}

Som det fremgår henvises alene til den almindelige bevisregel fastslået i NJA 1991 s. 481. Der åbnes således ikke mulighed for, at man ved anvendelse af en særlig bevisbyrderegel i relation til spørgsmålet om undersøgelsesgebyret kunne nå til et andet resultat, sådan som det var tilfældet i den parallelle danske sag nr. 96, refereret ovenfor under 6.3.1.1.

Ej heller i garanitilfælde anvendes nogen særlig bevisbyrderegel i relation til spørgsmålet om undersøgelsesgebyrets berettigelse. Dette fremgår af den følgende sag:

104. Sag 2003-06-05; 2003-0220

Klageren havde købt en mobiltelefon til kr. 3.310. Hun fik et års garanti. Det viste sig imidlertid, at telefonen ikke kunne oplades, og klageren indleverede derfor telefonen til forhandleren to dage efter købet. Forhandleren udskiftede batteriet, hvilket medførte, at telefonen nu virkede, men fortsat ikke tilfredsstillende. Ringesignalet og vibratorfunktionen virkede kun delvist. I den følgende periode udviste telefonen flere funktionssvigt, og klageren endte derfor med at indlevere telefonen til forhandleren, som sendte den til leverandøren med henblik på garantireparation. Ca. en måned efter fik klageren besked om, at telefonen var fugtskadet, 
og at garantien derfor ikke gjaldt. Da hun bad om at få telefonen tilbage uden reparation, fik hun at vide, at hun i så fald måtte betale kr. 370 i undersøgelsesgebyr. Det allmänna reklamationsnämnden udtalte, at fejlen var opstået inden for garantiperioden, og reglen i konsumentköplagens § 21 derfor var relevant. Sælgeren var derfor fri for ansvar, hvis han kunne sandsynliggøre, at fejlen skyldtes „en olyckshändelse eller därmed jämförlig händelse eller vanvård, onormalt brukande eller liknande förhållande på köparens sida“. Under henvisning til den vedlagte brugsanvisning fandt nævnet, at sælgeren havde løftet sin bevisbyrde og dermed ikke var ansvarlig for fejlfunktionen. For så vidt angik undersøgelsesgebyret udtalte nævnet i forlængelse heraf (som et obiter dictum), at det ikke fremgik af sagens oplysninger, om klageren var blevet orienteret om, at der skulle betales et undersøgelsesgebyr. Var det ikke tilfældet, havde klageren ret til at få telefonen udleveret uden at betale gebyret.

Som det fremgår anvendte man her også alene den almindelige bevisbyrderegel i relation til mangelsspørgsmålet og lod denne være afgørende i relation til spørgsmålet om, hvorvidt forbrugeren kunne afkræves et undersøgelsesgebyr. Der var således ikke mulighed for via en mere skærpet bevisbyrderegel (end sandsynliggørelse) at nå til, at forbrugeren, uanset om gebyret havde været aftalt mellem parterne eller ej, ikke kunne afkræves et sådant. Sml. herved dansk ret ovenfor under 6.3.1.1.

\title{
6.3.1.3 Norsk ret
}

I norsk ret findes en enkelt afgørelse, der kan ses som en illustration af princippet om, at et undersøgelsesgebyr ikke kan kræves, hvis varen er mangelfuld.

\section{Sag 51: Sak 2004/057:}

\begin{abstract}
Klageren havde købt en mobiltelefon til kr. 998. Telefonen „døde“, mens den blev brugt helt sædvanligt. Klageren indleverede telefonen til forhandleren, som fandt fugt i telefonen, og meddelte, at det ikke kunne betale sig at reparere den. Klageren blev afkrævet et undersøgelsesgebyr på kr. 250. Forbrukertvistutvalget fandt, at der ikke var tilstrækkelige holdepunkter for at antage, at klageren havde foretaget en brug af telefonen, som var udover det sædvanlige. Der henvistes herved også til formodningsreglen. Afhjælpning blev ikke anset for relevant, og da der var tale om en væsentlig mangel, kunne klageren hæve købet. Klageren havde derudover krav på tilbagebetaling af undersøgelsesgebyret.
\end{abstract}

Som det fremgår synes man heller ikke her at behandle spørgsmålet om tilstedeværelsen af en mangel som en separat problemstilling i relation til gebyrproblematikken. Det er dog begrænset, hvad der kan udledes af sagen i relation til dette spørgsmål, da bevisbyrden i forvejen synes at påhvile sælger som følge af formodningsreglen.

\subsubsection{Kravet skal være vedtaget mellem parterne}

Uanset om der foreligger et garantitilfælde eller ej, opstår spørgsmålet, hvilke vedtagelseskrav, der stilles, for at den erhvervsdrivende kan kræve 
et undersøgelsesgebyr. I de forskellige lovbestemmelser og de forskellige afgørelser refereret ovenfor anvendes forskellige formuleringer.

Efter den norske regel i § 30, stk. 4 kræves, at sælgeren har gjort forbrugeren „uttrykkelig oppmerksom på“, at han eller hun selv må dække omkostningerne til undersøgelsen. Efter den tilsvarende islandske bestemmelse i § 30, stk. 4 kræves at „,... sælgeren har gjort forbrugeren det klart ...“ at denne selv må betale omkostningerne. Der foreligger tilsyneladende hverken islandsk eller norsk praksis, der kan belyse den praktiske anvendelse af disse regler. Derimod foreligger en del svensk praksis, der kan belyse problemstillingen.

98. Sag 2002-5388

Klageren havde købt en printer i februar 2000. Hun fik et års garanti. Printeren blev indleveret til reparation i marts 2001, altså efter garantiperiodens udløb. For så vidt angik mangelsspørgsmålet udtalte nævnet, at det som udgangspunkt er køberen, der har bevisbyrden for, at varen var mangelfuld. Under henvisning til NJA 1991 s. 481, fastslås endvidere, at kravet er, ,at köparen skall visa att det är klart mer sannolikt att felet är ursprungligt än att det har uppstått till följd av en omst"ndighet som säljaren inte har att svara för“. Under anvendelse af denne regel vurderede man i den konkrete sag, at forbrugeren ikke havde løftet bevisbyrden og dermed ikke havde krav på afhjælpning. For så vidt angik spørgsmålet om undersøgelsesgebyr udtalte nævnet i forlængelse heraf, at eftersom det ikke var dokumenteret, at klageren var blevet oplyst om, at der ville blive opkrævet et undersøgelsesgebyr, skulle forhandleren tilbagebetale gebyret til klageren. (Fejlens karakter er ikke oplyst, og der gives ingen oplysninger om et evt. indleveringsbevis.)

102. Sag 2004-01-30; 2003-5753

Klageren havde købt et kamera. I forbindelse med at klageren indleverede kameraet til undersøgelse, blev han afkrævet kr. 275 i undersøgelsesgebyr. Udover at kræve ophævelse af købet, alternativt afhjælpning eller omlevering, krævede klageren de kr. 275 refunderet. Forhandleren afviste, at klageren havde misligholdelsesbeføjelser, men ville acceptere det hvis nævnet fandt, at der ikke skulle betales undersøgelsesgebyr. Det allmänna reklamationsnämnden udtalte, at da forhandleren ikke efter det oplyste havde orienteret klageren om, at han ville blive afkrævet et undersøgelsesgebyr, skulle gebyret refunderes. Nævnet afviste, at klageren havde misligholdelsesbeføjelser. Der gives ingen oplysninger om indholdet af et evt. indleveringsbevis.

103. Sag 2002-01-08; 2001-4712

Klageren havde købt en mobiltelefon for kr. 2.396. Han fik et års garanti. I garantiperioden ophørte telefonen med at fungere, og klageren indleverede derfor telefonen til reparation. Forhandleren oplyste efter endt undersøgelse, at det ikke var muligt at reparere telefonen, da den led af en fugtskade, og at klageren skulle betale kr. 175 for at få den tilbage. Det allmänna reklamationsnämnden udtalte, at telefonen efter det oplyste ikke led af en mangel. For så vidt angik undersøgelsesgebyret havde forhandleren ikke i forbindelse med købet af telefonen eller ved telefonens indlevering til undersøgelse oplyst, at klageren ville blive afkrævet et ge- 
byr. Forhandleren kunne derfor ikke afkræve klageren kr. 175 som betingelse for udlevering af telefonen.

Det fremgår af disse sager, at det er sælgeren, der har bevisbyrden for, at der er indgået aftale om betaling af et undersøgelsesgebyr. I ingen af sagerne ansås sælgeren for at have løftet denne bevisbyrde. Anderledes forholdt det sig i de følgende sager:

$$
\text { 100. Sag 2003-04-16; 2003-0292 }
$$

Klageren havde købt en mobiltelefon for kr. 1.395 i februar 2001. Hun fik tre års garanti. I december 2002 indleverede hun telefonen til forhandleren, idet knapperne og mikrofonen ikke virkede tilfredsstillende. Forhandleren oplyste, at telefonen led af en fugtskade, og at den derfor ikke kunne repareres. Klageren blev derudover afkrævet et undersøgelsesgebyr på kr. 395. Klageren ville have telefonen tilbage uden at betale gebyr. Forhandleren henviste til, at det fremgik af indleveringskvitteringen, at klageren ville blive afkrævet et gebyr, hvis der fandtes en fejl, som ikke var omfattet af garantien. Det allmänna reklamationsnämnden udtalte, at det var tilstrækkeligt, at det fremgik af indleveringskvitteringen, at klageren ville blive afkrævet et gebyr, hvis der fandtes en fejl, som ikke var omfattet af garantien. Klageren kunne derfor ikke forlange telefonen udleveret uden at betale gebyret.

\section{Sag 2003-04-16; 2002-8596:}

Klageren havde købt en mobiltelefon for kr. 1.689 i februar 2001. Han fik tre års garanti. I december 2002 indleverede han telefonen til forhandleren, idet knapperne og mikrofonen ikke virkede tilfredsstillende. Forhandleren oplyste, at telefonen led af en fugtskade, og at den derfor ikke kunne repareres. Klageren blev derudover afkrævet et undersøgelsesgebyr på kr. 395. Klageren ville have telefonen tilbage uden at betale gebyr. Forhandleren henviste til, at det fremgik af indleveringskvitteringen, at klageren ville blive afkrævet et gebyr, hvis der fandtes en fejl, som ikke var omfattet af garantien. Det allmänna reklamationsnämnden udtalte, at det var tilstrækkeligt, at det fremgik af indleveringskvitteringen, at klageren ville blive afkrævet et gebyr, hvis der fandtes en fejl, som ikke var omfattet af garantien. Klageren kunne derfor ikke forlange telefonen udleveret uden at betale gebyret.

105. Sag 2004-04-05; 2004-0032

Klageren havde købt en mobiltelefon til kr. 2.100. Hun fik et års garanti. Ca. 7 måneder efter købet indleverede klageren telefonen til forhandleren, idet der var en fejl i mikrofonen. Ifølge forhandleren var telefonen fugtskadet. Klageren måtte betale kr. 375 for at få telefonen udleveret uden reparation. Forhandleren oplyste, at klageren var blevet orienteret om hvilke omkostninger, klageren ville blive afkrævet, hvis der ikke fandtes en fejl, som var omfattet af garantien. Det allmänna reklamationsnämnden udtalte, at telefonen efter det oplyste ikke led af en mangel. For så vidt angik undersøgelsesgebyret udtalte nævnet, at det fremgik af indleveringskvitteringen, at klageren vil blive afkrævet et gebyr for foretaget undersøgelse og returfragt, hvis reparationen afbestilles. Gebyret skulle derfor ikke refunderes. 
Af disse afgørelser fremgår, at man i svensk ret gennem en periode har været tilbøjelig til at anse kravet om vedtagelse for opfyldt, hvis sælgeren kunne fremlægge en indleveringskvittering med vilkår om undersøgelsesgebyr. En nyere afgørelse synes imidlertid at skærpe kravene til beviset for, at der inden indleveringen forelå en sådan aftale.

106. Sag 2004-12-22, 2004-5311

En forbruger, A, havde købt en mobiltelefon med et års garanti. Knapt et år efter købet indleverede A mobiltelefonen til sælgeren, B, fordi nogle af knapperne var ophørt med at fungere. Hun fik efter det oplyste ingen information om hvilke vilkår, som gjaldt for garantireparation, herunder at hun kunne risikere at blive afkrævet et undersøgelsesgebyr. A ville derfor have mobiltelefonen retur uden at betale for undersøgelsen, hvilket B nægtede. B henviste i den forbindelse til, at det fremgik af indleveringskvitteringen, at der ville blive opkrævet et undersøgelsesgebyr, hvis undersøgelsen viste, at mobiltelefonen havde været udsat for ydre påvirkning i form af fugt mv. Det allmänna reklamationsnämnden fastslog, at det ikke fremgik, at A var blevet mundtligt orienteret om forpligtelsen til at betale et undersøgelsesgebyr, hvis B ikke var ansvarlig for en fejl ved mobiltelefonen. Nævnet udtalte herefter: „Frågan är om en information som endast lämnats skriftligen på ett inlämningsbevis kan anses vara tillräckligt klargörande för att en undersökningsavgift skall kunna tas ut.“ Nævnet nåede til, at det ikke var tilstrækkeligt, at vilkåret fremgik af indleveringsbeviset, når dette blev udleveret samtidig med, at varen blev indleveret til undersøgelse. Der var i så fald tale om et ensidigt fastsat aftalevilkår, som A ikke var bundet af. Nævnet tilføjede: „Det sagde innebär emellartid inte att en uuplysning om undersöknngsavgift på ett inlämningskvitto skulle sakna värde. Tvärtom kan en sådan skriftlig upplysning ha bevisvärde för att information har lämnats.“ I det konkrete tilfælde var det ikke gjort gældende, at forbrugeren havde fået informationen inden indleveringen af varen, hvorfor A havde ret til at få udleveret mobiltelefonen uden at betale et undersøgelsesgebyr.

I denne afgørelse anerkendes indleveringsbeviset således ikke i sig selv som tilstrækkelig dokumentation for, at der er indgået en aftale om betaling af undersøgelsesgebyr. Der skal foreligge yderligere omstændigheder, som i sammenhæng med et evt. indleveringsbevis, evt. kan udgøre tilstrækkeligt bevis for, at en sådan aftale er indgået før indleveringen af varen til undersøgelse. Som det fremgår af afgørelsen, må det som minimum kræves, at det bliver gjort gældende af sælgeren, at en sådan (mundtlig) aftale forelå. Med den sidst refererede svenske afgørelse er således fastslået det selvfølgelige, at vedtagelseskravet indebærer, at der må være holdepunkter for at antage, at vilkåret er aftalt mellem parterne før indleveringen.

Da aftalevilkåret er bebyrdende for forbrugeren, er det imidlertid nærliggende at overveje, om der gælder særlige fremhævelseskrav. I ingen sager nævnes dette udtrykkeligt. Det kan således ikke udledes af den foreliggende praksis, at der skulle gælde et krav om, at et skriftligt vilkår er særskilt, mundtligt påpeget over for forbrugeren (dog den seneste 
svenske afgørelse) eller fremhævet i aftaleteksten med særlig skrifttype eller lignende.

I de ovenfor refererede afgørelser anvendes udtrykket „udtrykkeligt aftalt“ (sagerne $94+96$ (dansk ret uden for garantitilfælde)), udtrykket „gjort bekendt med“ (sagerne $91+93$ (dansk ret, garantitilfælde)), udtrykket „oplyst om“ (sagerne $98+103$ (svensk ret) +95 (dansk ret)), udtrykket „orienteret om“ (sagerne $104+105$ (svensk ret)). Umiddelbart synes udtrykket „udtrykkeligt aftalt“ at repræsentere det strengeste krav til vedtagelse, idet der her ikke efterlades nogen tvivl om, at der udover en erklæring fra sælgers side også kræves en accept fra købers side, og at den således indgåede aftale herudover må være udtrykkelig. De øvrige formuleringer efterlader umiddelbart et indtryk af knapt så strenge krav til vedtagelsen. Formuleringerne kunne tyde på, at en erklæring fra sælgers side er tilstrækkelig, når blot der ikke protesteres fra forbrugerens side. Det er dog vanskeligt at sige, om de forskellige udtryk i realiteten dækker over nogen indholdsmæssig forskel. De forskellige formuleringer dækker formentlig alle blot over det forhold, at det ud fra en konkret vurdering i det enkelte tilfælde må vurderes, om vilkåret kan anses for vedtaget.

\subsubsection{Ugyldighedsregler}

6.3.3.1 Betydningen af gebyret set i forhold til de faktiske omkostninger ved mangelsundersøgelsen

I overensstemmelse med almindelige aftaleretlige principper skal det undersøgelsesgebyr, den erhvervsdrivende afkræver forbrugeren, være rimeligt. ${ }^{69}$ Til belysning heraf kan nævnes følgende sager:

95. Sag nr. 49: 2003-4021/7-45

En forbruger, A, beskadigede sit kamera som følge af, at memory-kortet var indsat forkert. Den erhvervsdrivende, B, forlangte forud for undersøgelsen af kameraet et gebyr på kr. 459, såfremt fejlen viste sig at skyldes A’s forhold. A gjorde gældende, at beskadigelsen skyldtes, at brugsanvisningen ikke var udførlig nok og indbragte sagen for Forbrugerklagenævnet. Forbrugerklagenævnte fandt, at skadens indtræden hovedsagelig måtte anses for at bero på A's egen uforsigtighed og manglende omtanke. Nævnet gav derfor ikke A medhold i, at A kunne gøre mangelsbeføjelser gældende mod B som følge af, at brugsanvisningen havde været mangelfuld. Hvad angår det undersøgelsesgebyr på kr. 459, som B havde betinget sig, såfremt der ikke var tale om mangler, var det ubestridt, at A blev oplyst herom ved kameraets indlevering til undersøgelse. Under hensyn hertil samt til, at skaden på kameraet skyldtes A’s egne forhold, var B ikke afskåret fra at opkræve gebyret, forudsat at det ikke oversteg, hvad der måtte anses for et rimeligt vederlag for den af B foretagne undersøgelse. Idet nævnet gik ud fra, at B’s værksted havde været nødt til at ad-

\footnotetext{
${ }^{69}$ Se hertil Sonny Kristoffersen: Forbrugerbeskyttelse - ved køb af løsøre og tjenesteydelser, erhvervelse af fast ejendom, kreditaftaler og betalingsmidler (2004) s. 130f.
} 
skille kameraet for at undersøge skaden og dens omfang, fandt nævnet ikke grundlag for at anfægte gebyrets størrelse, og nævnet kunne derfor heller ikke give A medhold i den del af klagen, som vedrørte det opkrævede undersøgelsesgebyr.

Hvorvidt et gebyr er rimeligt eller ej, vil i reglen bero på en konkret vurdering. På baggrund af den foreliggende praksis, jf. ovenfor, kan det dog konstateres, at undersøgelsesgebyrer på mellem dkr. 250 og dkr. 500 generelt anses for rimelige, alt afhængig af salgsgenstandens art og omfanget af undersøgelserne. Det kan imidlertid ikke afvises, at selv et undersøgelsesgebyr på dkr. 250 kan være urimeligt, og det kan heller ikke afvises, at undersøgelsesgebyrer, som overstiger dkr. 500, kan være rimelige. Der skal dog være tale om omfangsrige eller komplicerede undersøgelser, før et gebyr på mere end dkr. 500 vil blive anset for at være rimeligt.

\subsubsection{Betydningen af undersøgelsens nødvendighed}

Selv om et undersøgelsesgebyr er aftalt mellem parterne, og undersøgelsen af salgsgenstanden viser, at denne ikke lider af en mangel, er det ikke altid, at undersøgelsesgebyret kan kræves betalt. Er foretagelsen af en undersøgelse således ufornøden, fordi det er åbenbart, hvad der er årsagen til manglen, har den erhvervsdrivende ikke krav på noget gebyr, da opkrævningen ville være i strid med almindelig hæderlighed, jf. AFTL § 33. Dette illustreres af den følgende sag:

92. Sag 2003-4031/7-225

En forbruger, A, konstaterede efter montering af et RAM-modul, at dette ikke fungerede og klagede til den erhvervsdrivende, B. A blev opkrævet et undersøgelsesgebyr på $250 \mathrm{kr}$. af $\mathrm{B}$, idet denne mente, at modulet var beskadiget som følge af A's egne forhold. Beskadigelsen af RAM-modulet skete som følge af A's fejlmontering. Forbrugerklagenævnet udtalte, at A ikke havde krav på gratis afhjælpning, idet skaden var forårsaget af A selv. For så vidt angik det opkrævede undersøgelsesgebyr udtalte nævnets faste sagkyndige, der bistod nævnet på mødet, at det blot ved en umiddelbar besigtigelse af RAM-modulet har været muligt for B at konstatere skadens omfang og årsag, og at det dermed ikke har været nødvendigt for B at iværksætte en egentlig undersøgelse af varen. B havde derfor opkrævet et gebyr, som det ville være urimeligt eller i strid med redelig handlemåde at gøre gældende, hvorfor A havde krav på tilbagebetaling

\subsection{Komparativ sammenfatning}

Spørgsmålet om den erhvervsdrivendes adgang til at opkræve gebyr for undersøgelser af salgsgenstanden med henblik på at få konstateret, om genstanden lider af en mangel, er i vid udstrækning reguleret identisk i de nordiske lande. Praksis i de lande, som ikke har lovregler herfor (Dan- 
mark, Finland og Sverige), svarer indholdsmæssigt grundlæggende til den lovregulering, der findes i andre nordiske lande (Island og Norge).

På baggrund af undersøgelsen af lovgivning og praksis kan det konkluderes, at den erhvervsdrivende i ingen af de nordiske lande kan opkræve et gebyr hos forbrugeren for omkostninger til undersøgelse af salgsgenstanden, såfremt undersøgelsen måtte afsløre, at genstanden lider af en mangel. Forbrugeren har i disse tilfælde krav på at få afhjulpet manglen gratis, jf. hertil Forbrugerkøbsdirektivets art. 3, stk. 2. Den erhvervsdrivende kan derfor alene opkræve et gebyr hos forbrugeren i tilfælde, hvor undersøgelsen ikke afslører tilstedeværelsen af en mangel. Bevisbyrden for, at varen ikke er mangelfuld, påhviler i dansk ret sælgeren. Dette fremgår udtrykkeligt af dansk praksis. Der foreligger ikke praksis, der kan belyse, hvad der gælder i de øvrige nordiske lande, bortset fra svensk ret. Her gælder tilsyneladende ingen særlig bevisbyrderegel vedrørende mangelspørgsmålet i relation til spørgsmålet, om der kan kræves undersøgelsesgebyr. Det synes at være de almindelige bevisbyrderegler, der anvendes, således at det som udgangspunkt er forbrugeren, der skal bevise, at der foreligger en mangel, omend bevisbyrdekravet er lempet. Efter dansk forbrugerklagenævnspraksis gælder endvidere en særregel for garantitilfælde. I garantitilfælde skærpes kravene til sælgers bevis for, at der ikke er tale om en mangel, som han hæfter for under garantien. En tilsvarende særregel for garantitilfælde ses ikke udviklet i de øvrige nordiske lande, omend sælger efter den svenske konsumentköplags $\S 23$ i garantitilfælde generelt som udgangspunkt bærer bevisbyrden for, at der ikke foreligger mangler. Det gælder derimod generelt, at et undersøgelsesgebyr kun kan kræves, dersom dette har været aftalt mellem parterne senest på tidspunktet for salgsgenstandens indlevering til undersøgelse. I svensk ret synes man i en periode at have anerkendt et aftalevilkår i indleveringssedlen som tilstrækkeligt til at opfylde kravet om vedtagelse. Med en nyere afgørelse må denne praksis imidlertid anses for ændret. Der gælder herefter formentlig samme krav om foretagelsen af en konkret bedømmelse i hvert enkelt tilfælde under inddragelse af en evt. indleveringsseddel i samtlige nordiske lande. Den erhvervsdrivende har under ingen omstændigheder krav på et undersøgelsesgebyr, hvis den foretagne undersøgelse ikke var nødvendig til konstatering af manglen. Endvidere skal undersøgelsesgebyret være rimeligt. Det må således ikke stå i et uforholdsmæssigt forhold til de undersøgelsesforanstaltninger, den erhvervsdrivende skal gennemføre. 


\section{Litteraturliste mv.}

\section{Litteratur:}

Dahl og Møgelvang-Hansen, Garantier, 1985

Viggo Hagstrøm, Kjøpsrett, 2005

Jonny Herre, Konsumentköplagen, En kommentar, 2. udgave, 2004

Sonny Kristoffersen, Forbrugerbeskyttelse - ved køb af tjenesteydelser, erhvervelse af fast ejendom, kreditaftaler og betalingsmidler, 2004.

Joseph Lookofsky, Køb, Dansk indenlandsk købsret, 2. udgave, 2002

Erling Selvig, Kjøppsrett til studiebruk, 3. udgave, 2006

Love:

Danmark:

Lovbekendtgørelse nr. 237 af 28.3.2003 om køb (købeloven)

\section{Norge:}

Lov av 21. juni 2002 nr. 34 om Forbrukerkjøp (Forbrukerkjøpslagen)

Lov av 13. mai 1988 nr. 27 om Kjøp (Kjøpslagen)

Island:

Lov nr. 48/2003 om forbrugerkøb (forbrugerkøbsloven)

Lov nr. 50/2000 om løsørekøb (købeloven)

Sverige:

Lag 1990:931 (Köplag)

Lag 2002:553 (Konsumentköplag)

Lag (2005:62) (Lag om ändring i konsumentköplagen (1990:032))

Finland:

Lag 38/1978 (Konsumentskyddslagen)

Lovforarbejder:

Danmark:

Betænkning 1403/2001 om implementering af

Sverige:

Prop.2001/ 02:134, Ändringer i konsumentköplagen.

Finland

RP 89/2001

Ekonomiutskottets betänkande RP 18/2001 rd.

Norge:

Innst.O nr. 51 (1987-88)

Ot.prp.nr. 44 (2001-2002)

NOU 1993:27

Undersøgelser:

Bo Kristensen m.fl., „Nye regler om forbrugerkøb - en empirisk undersøgelse, CBS, 2005. Forbrugerstyrelsen, Forbrugerredegørelse 2004, 2004. 



\section{Yfirlit}

\section{Resumé - islandsk}

Með tilskipun ES 1999/44EF um tiltekin sjónarmið varðandi neytendakaup og ábyrgðir er peim tengjast voru að ákveðnu marki innleiddar nýjar reglur í kauparétti varðandi neytendakaup. Dessi tilskipun gerði pað að verkum að nauðsynlegt var að breyta reglum norrænna kauparéttarlaga varðandi neytendakaup. Reglur tilskipunarinnar voru teknar upp í löggjöf pessara landa og tóku breytingarnar gildi á tímabilinu 2001 til 2003. Markmiðið með pessari skýrslu er að útskýra framkvæmd pessara nýju reglna.

Í raun er um að ræða fjögur vandamálasvið, p.e.: beiting hinnar nýju líkindareglu, en samkvæmt henni er galli sem fram kemur á vöru innan sex mánaða frá afhendingu talinn hafa verið fyrir hendi á afhendingartíma, tveggja-ára umkvörtunarfrestur samkvæmt tilskipuninni, reglur tilskipunarinnar um pau úrræði neytanda, pegar vara er gölluð, að eiga val um pað hvort hann óski eftir pví að fá nýja vöru í stað peirrar gölluðu eða hvort hann óski eftir bví að bætt verði úr göllum, nema önnur hvor pessara heimilda teljist ósanngjörn, auk reglna tilskipunarinnar um að bætt verði úr ókeypis úr göllum með hliðsjón af framkvæmdinni í tengslum við innheimtu skoðunargjalds.

par eð reglurnar eru tiltölulega nýlegar eru til takmarkaðar heimildir úr réttarframkvæmd er bær varða. Tekist hefur að safna saman rúmlega 100 úrskurðum frá norrænum úrskurðarnefndum í neytendamálum, sem geta varpað ljósi á pessi vandamál. аð eru pessir úrskurðir sem verða teknir til frekari skoðunar í pessari skýrslu.

\section{Líkindareglan}

Líkindaregla tilskipunarinnar hefur verið tekin upp næstum orðrétt í peim réttarkerfum sem skoðuð hafa verið, en samkvæmt henni má ætla að galli, sem sannreynt er að sé fyrir hendi á fyrstu 6 mánuðum eftir afhendingu, hafi verið til staðar á afhendingartíma. Dó er reglunni beitt með nokkuð mismunandi hætti í peim réttarkerfum sem skoðuð voru. Sterkasta dæmið um „beina“ notkun reglunnar sést í sænskum og norskum rétti. Samkvæmt pessum réttarkerfum er reglunni pannig beitt að ekki er reynt að skoða hvort neytandi hafi í sjálfu sér getað sannað eða leitt líkur að pví að gallinn hafi verið fyrir hendi á afhendingartíma. Eftir pví sem best verður séð gildir petta án tillits til pess hvers konar vöru er um að ræða. Annað gildir í dönskum og finnskum rétti. Í báðum pessum réttarkerfum - pó á petta frekar við um danskan rétt - aflar Úrskurðarnefnd í neytendamálum umsagnir fagaðila í pví skyni að varpa ljósi á galla. Með pessum hætti er 
lagður grunnur að pví að framkvæma sönnunarmat óháð líkindareglunni, og bað einkennir bæði réttarkerfi að reglunni er sérstaklega beitt í pví skyni að renna styrkari stoðum undir málstað neytanda hafi neytanda ekki tekist að færa fullar sönnur á pví að gallinn hafi verið til staðar á afhendingartíma (samkv. finnskum rétti) eða sem grundvöll fyrir beitingu reglunnar sé talið að leiddar hafi verið líkur að pví að galli hafi verið til staðar á afhendingartíma (samkv. dönskum rétti). Að pví er varðar danskan rétt er pó hægt að slá pví föstu að bein líkindafærsla er ekki talin vera skilyrði fyrir pví að hægt sé að beita líkindareglunni. Til dæmis er reglunni einnig beitt í málum er snerta tæknileg atriði par sem neytandi getur ekki sannað eða leitt líkum að pví að galli hafi verið til staðar við afhendingu og á sama tíma er ekki grundvöllur til að gera ráð fyrir að gallinn hafi komið fram síðar. Notkun umsagna eða álita fagaðila í finnskum og dönskum rétti felur í sér að seljandi á að öllu jöfnu betri möguleika á pví að létta sönnunarbyrðinni samkvæmt pessum réttarkerfum hendur en samkvæmt norskum og sænskum rétti.

раð er sameiginlegt öllum peim réttarkerfum, sem skoðuð voru, að seljandi losnar undan ábyrgð, geti hann sannað að galli hafi ekki verið til staðar á afhendingartíma. Í mörgum málum er kröfum seljanda hafnað með tilvísun til pess að hann hafi ekki fært nægar sönnur á réttmæti krafna. Í öðrum málum virðist eingöngu gerð krafa til pess að seljandi hafi leitt líkur að pví að gallinn hafi fyrst komið upp síðar. Á hinn bóginn er erfitt að segja til um hvort pað sé raunverulegur munur á peim kröfum sem gerðar eru til pess hversu ,sterk“ sönnunin parf að vera. Аð jafnaði eru pað fá mál par sem seljanda tekst að losna undan ábyrgð. Dæmigerð mál fjalla um flíkur sem ekki hafa verið notaðar á réttan hátt svo og um dýr sem hafa sýkst á síðari stigum. Að pví er varðar tæknileg atriði pá er venjulega erfitt fyrir seljanda að létta af sér sönnunarbyrðinni. Varðandi farsíma finnst einungis eitt mál par sem seljandi telst hafa létt af sér sönnunarbyrðinni. Venjulega er pess að minnsta kosti krafist að fyrir liggi umsögn fagaðila sem styður málstað seljanda. Í finnskum rétti eru pó fyrir hendi nokkur mál par sem seljandinn er leystur undan ábyrgð prátt fyrir að slík umsögn hafi ekki verið fyrir hendi. Samkvæmt dönskum rétti gæti pað gerst að mál um farsíma yrði vísað frá par sem pau eru ekki talin til pess fallin að uppfylla reglur um sönnunarfærslu fyrir úrskurðarnefnd í neytendamálum.

Fá mál eru til sem snerta ósamrýmanleikahugtakið. Detta hugtak er sérstaklega notað í málum varðandi kaup og sölu á notuðum bílum. Í engu pessara mála er komist skýrt að orði og sagt að pað samræmist ekki líkindareglunni pegar rætt er um notaðar vörur. Dessi mál varða aðallega pá spurningu að hve miklu leyti einkenni gallans feli í sér að fyrir hendi sé ósamrýmanleiki. Tvö mál varðandi farsíma snerta spurninguna um pað, hvort pau atvik að raka- og vatnstjón myndist fyrst töluverðum tíma eftir afhendingartímann, feli í sér að eðli gallans verði að teljast vera ósamrýmanlegt beitingu líkindareglunnar. Svörin við pessari spurningu 
eru játandi (samkv. sænskum rétti) að pví er varðar vatnstjón, og neitandi (samkv. norskum rétti) að pví er varðar rakatjón. Ósamrýmanleikahugtakið er að langmestu leyti notað í skilningi sem ekki er strangur. Detta hefur í för með sér að pað eru fljótandi mörk milli tilvika par sem um er að ræða ósamrýmanleika og tilvika par sem seljandi telst hafa fært sönnur á t.d. ranga notkun varnings.

Að pví er varðar pekkingu á notkun reglunnar innan atvinnugreinar bá liggja fyrir tvær danskar kannanir sem að hluta virðast vísa í mismunandi áttir. Í einni könnun sem framkvæmd var af CBS var komist að peirri niðurstöðu að líkindareglan virðist hafa öðlast meiri býðingu í framkvæmd en áformað var og búist hafði verið við, en niðurstaða könnunar, sem framkvæmd var af Úrskurðarnefnd í neytendamálum, var sú að tölur bendi til pess að mikill og almennur skortur sé á pekkingu á líkindareglunni.

\section{Kvörtunarfrestur}

Með tilskipuninni var innleiddur tveggja ára ófrávíkjanlegur kvörtunarfrestur frá afhendingu vörunnar. Útvíkkun reglunnar hafði aðeins í för með sér beinar ápreifanlegar afleiðingar að pví er Danmörk og Ísland varðar pegar reglan var innleidd par eð önnur norræn lönd voru með löggjöf sem ýmist var með tveggja ára eða fimm ára kvörtunarfrest, eða pá að ekki var um neinn kvörtunarfrest að ræða. Árið 2005 var fresturinn lengdur úr tveimur í fimm ár í sænskum rétti.

Í sambandi við spurninguna um aðstöðuna varðandi sönnunarbyrði og styrk sönnunar á tímabilinu frá pví að sex mánaða tímabilið er liðið og fram að pví að kvörtunarfrestur er liðinn er hægt að draga saman niðurstöður könnunarinnar í pá veru að pau yfirvöld sem beita pessum réttarreglum í Danmörku, Noregi og Svípjóð leggja pað til grundvallar að eftir að sex mánaða tímabilið er liðið er pað neytandinn sem ber sönnunarbyrðina fyrir pví að fyrir hendi hafi verið bilun í framleiðsluhlut pegar varan var afhent og varan par af leiðandi gölluð. Bæði í norskum og sænskum rétti er á hinn bóginn gerðar tiltölulega litlar kröfur til sönnunarfærslu neytandans. Samkvæmt norskum rétti virðast menn á grundvelli reglunnar um sönnunarbyrði seljanda í raun nálgast pað að beitt sé líkindareglu til hagsbóta fyrir neytanda sem einnig gildir utan sexmánaða tímabilsins. Petta kemur fram með sérlega skýrum hætti í málum sem falla undir 5 ára kvörtunarfrestinn. Ef ekki er hægt að segja að galli á vörunni stafi af aðstæðum er varða neytandann sjálfan eða öðru slíku, telst neytandinn hafa létt sönnunarbyrðinni varðandi upprunalegan galla. Í sænskum rétti er greint á milli tilvika pegar um ábyrgð er að ræða og annarra tilvika. Taki ábyrgð á söluhlut til gallans ber seljandi sönnunarbyrðina fyrir pví að gallinn stafi af atvikum er varða aðstæður neytandans eða öðru slíku. Falli tilvikið ekki undir ákvæði ábyrgðar ber neytandi sönnunarbyrðina en hún er milduð pannig að nægilegt teljist að skýringar neytandans séu að mati úrskurðarnefndar í neytendamálum sennilegri en 
skýringar seljanda. Hvorki norsk né sænsk réttarframkvæmd virðist sýna nein merki pess að hún hafi breyst eftir að líkindareglan var tekin upp. Í norskri réttarframkvæmd er aðaldómurinn á bessu sviði ennpá Rt 1998.766 og í Svípjóð er ennpá vísað í fræðiritum til framanreifaðra niðurstaðna frá árunum uppúr 1990. •að er flóknara að meta stöðuna í danskri réttarframkvæmd. Hér ræður algerlega úrslitum efni pess álits eða umsagnar sem úrskurðarnefnd í neytendamálum hefur aflað hjá fagaðilum. аð má ganga út frá pví að pað sé aðeins í peim tilvikum sem umsögnin er neytanda í hag sem hann fær kröfum sínum framgengt. Styðji umsögn atvinnurekandann í sama mæli og hún styður neytandann leggst sönnunarbyrðin á neytandann pannig að kröfur neytanda ná ekki fram að ganga nema um sé að ræða sérstakar aðstæður, eins og t.d. að kvartað sé skömmu eftir að sex mánaða fresturinn er liðinn. Degar allt er skoðað virðist í danskri réttarframkvæmd vera um að ræða allstrangar kröfur um sönnunarbyrði neytenda eftir að sex mánaða fresturinn er liðinn og er petta gagnstætt peim væntingum sem fram koma í greinargerð með lögum. Mismunurinn milli réttarkerfa virðist einkum stafa af pví að danska úrskurðarnefndin í neytendamálum aflar sjálf sérfæðimatsgerða, en samkvæmt norsku og sænsku réttarkerfunum sjá aðilar í grundvallaratriðum um að afla gagna.

„Kvörtunargildran“ er sú aðstaða að frestur seljanda gagnvart framleiðanda getur orðið styttri en frestur neytanda til að kvarta við seljanda. Öll norrænu réttarkerfin, nema hið finnska, fela í sér sáðkorn vandamálsins sem er að lengd kvörtunarfresta getur verið mismunandi á mismunandi prepum söluferlis vörunnar. Könnun á framkvæmdinni sem fram fór í Danmörku sýnir einnig að frestir pessir eru mjög oft raunverulega mismunandi. Að hve miklu leyti betta veldur vandamálum í framkvæmd er hins vegar erfiðara að meta. Í einstökum úrskurðum hafa möguleikar seljanda til að leggja fram kvartanir við framleiðanda verið reifaðir en ekki finnast greinileg merki úr peirri réttarframkvæmd sem skoðuð var um að seljandi álíti eigin möguleika á pví að koma að kvörtunum skipta máli varðandi pað hvort neytandi eigi rétt á hendur sér. petta útilokar að sjálfsögðu ekki að pessi röksemdarfærsla sé notuð í framkvæmd í smásöluverslun.

\section{Mat á ósanngirni}

pau ákvæði sem fjalla um ósanngirnisviðmið í 3. mgr. 3 gr. tilskipunarinnar hafa í miklum mæli verið tekin upp samhljóða í norrænum löndum en pó er nauðsynlegt að benda á mismunandi fyrirkomulag í löndunum. Í fyrsta lagi er tungumálalegur áhersluauki í lagatexta í Noregi og á Íslandi varðandi valrétt neytenda og í öðru lagi er um að ræða „fjórða viðmiðið“, sem er lögfest í sænska lagatextanum. Samkvæmt pví á við mat á ósanngirni að hafa til hliðsjónar hvort önnur valkvæð leið sé framkvæmanleg með lægri kostnaði en sú leið sem verður fyrir valinu. pessi mismunur á einstökum framkvæmdaatriðum virðist að ákveðnu 
marki endurspeglast í framkvæmdinni. Ekki eru fyrir hendi nein mál um pá aðstöðu par sem neytandinn fer fram á að bætt verði úr göllum frekar en að fá nýja afhendingu (p.e. afhending ógallaðrar vöru í stað gallaðrar). Hér á eftir verður fjallað um gagnstæðar aðstæður pegar neytandi krefst nýrrar afhendingar fremur en að bætt verði úr göllum.

Samkvæmt ráðandi viðmiði ber að líta til pess hvort kostnaður sem tengist nýrri afhendingu sé ótilhlýðilegur samanborið við kostnaðinn sem hlýst af pví að bæta úr göllum. Framkvæmdin í Danmörku og Noregi hefur verið sú að kostnaður sem hlýst af nýrri afhendingu miðist í grundvallaratriðum við innkaupsverð vörunnar til seljanda. Рað virðist eingöngu vera í Danmörku par sem framkvæmd úrskurðarnefndar í neytendamálum hefur teygt sig lengra og tekið tillit til pess að pað geti einnig skipt máli hvort seljandi geti endurselt viðkomandi vöru sem lítið notaðan sölumun.

Í sambandi við viðmiðið um „,verðmæti hlutarins“ hefur framkvæmdin í Danmörku og Noregi verið sú að pað beri að skilja petta pannig að lítið verðmæti er að öllu jöfnu rök fyrir nýrri afhendingu. betta grundvallarsjónarmið styðst einnig við löggjafargögn. Hins vegar er síður ljóst hvernig beri að meta pað hvort verðmæti sé lítið eða mikið.

Að pví er varðar viðmiðið um ,,pýðingu gallans“ hefur pví verið slegið föstu í norskri réttarframkvæmd að með pessu hugtaki beri að líta til pess hvort telja megi gallann vera verulegan að pví er notkun hlutarins varðar.

Hvað varðar viðmiðið sem orðað er ,án verulegra ópæginda fyrir neytandann“ pá sést af danskri og norskri réttarframkvæmd að með pessu sé átt við hversu skjótt megi bæta úr galla, hvort hluturinn, eftir að bætt hefur verið úr göllum, beri með sér aðra ágalla en útlitslega, og hvort neytandinn í einstökum tilfellum eigi óhægt með að vera án viðkomandi hlutar.

Að auki sést af framkvæmdinni að auk hinna priggja viðmiða tilskipunarinnar er einnig stuðst við önnur viðmið pegar meta á hvort heimild til að bæta úr galla sé ,,ósanngjörn“.

раð er einkenni sænsks réttar að lögð er, að pví er virðist, afgerandi áhersla á pað pegar afhentur er ógallaður hlutur í stað gallaðs hvort slík afgreiðsla „hafi verulega meiri kostnað í för með sér“ fyrir seljandann en ef hann myndi bæta úr göllum (,,meginreglan um krónu fyrir krónu“). Ástæðan fyrir pví að petta viðmið er notað í sænskum rétti en ekki í rétti annarra Norðurlanda, verður að teljast vera sú að petta stafi af pví að kveðið er ótvírætt á um petta viðmið í sænska lagatextanum. Athyglisvert er að í dómi norska Lagmannsretts kemur skýrlega fram andstaða við að beita pessu viðmiði skilyrðislaust. Væntanlega er pví nokkuð erfiðara að ná fram kröfu um nýja afhendingu samkvæmt sænskum rétti en samkvæmt norskum rétti.

par að auki er pað einkenni á norskum rétti að bæði í löggjafargögnum svo og í dómstólaframkvæmd hefur mikilvægi umhverfissjónarmiða verið 
afnumið. Samt verður pá að álíta pað vera nokkuð óljóst hvaða merkingu petta tillit hefur og hvort umhverfissjónarmið mæli ótvírætt gegn nýrri afhendingu og hvort e.t.v. beri að greina á milli mismunandi vöruflokka og e.t.v. milli nýrrar afhendingar pegar um einn einstakan hlut er að ræða annars vegar og hins vegar vörusafn.

Framkvæmdin á Norðurlöndum sýnir að öðru leyti að matið á ósanngirni getur skipt máli ekki aðeins varðandi pau tengsl sem eru milli pess að bæta úr galla og að afhenda nýjan hlut, heldur einnig varðandi tengsl sem eru milli pess að bætt er úr galla og afsláttar eða milli pess að bætt er úr galla og kaupum rift.

раð virðist vera almennt álitið að seljandi beri sönnunarbyrðina fyrir pví að sú heimild sem neytandinn ætlar að styðjast við, sé ósanngjörn. petta endurspeglar pá meginreglu tilskipunarinnar að pað sé neytandinn sem á rétt á vali, og pað einnig í réttarkerfum par sem slíkt er ekki skýrt orðað í lagatextanum. Áhrifin af pessu sjást einnig í framkvæmd dönsku úrskurðarnefndarinnar í neytendamálum, par sem pví er oft slegið föstu í forsendum úrskurða að neytandinn eigi valréttinn jafnvel pótt meginreglan hafi ekki verið skýrt orðuð í lagatextanum.

Hvorki tilskipunin né norræn lagaákvæði slá pví föstu að seljanda sé skylt að upplýsa neytanda um pennan valrétt samkvæmt reglunum. Engu að síður sýnir réttarframkvæmdin að skortur á upplýsingum frá hendi seljanda getur orðið til tjóns fyrir hann.

Með pví að draga framangreint saman er komist að peirri niðurstöðu að pó svo mat á ósanngirni fari fram með pví að vega áhrif að einhverju leyti mismunandi viðmiða sem beitt er meðal Norðurlandanna kemur fram sú ráðandi mynd af stöðunni par að réttarfarsyfirvöld séu meðvituð um að matið á ósanngirni eigi að endurspegla breytingu á réttarástandi neytanda í hag eins og markmiðið var með hinum nýju lagareglum.

pessi skilningur á reglunum ætti einnig að birtast með peim hætti sem peim er beitt í framkvæmd innan hverrar atvinnugreinar. Í CBS könnuninni frá 2005 var petta atriði kannað að pví er varðar danskan rétt. Með könnuninni var pví slegið föstu að rúmur 2/3 hluti peirra sem spurðir voru töldu ekki að nýju reglurnar hefðu haft nein áhrif, en tæpur 1/3 hluti peirra sem spurðir voru fundust reglurnar hafa haft tilætluð áhrif en pó í mismiklum mæli. Niðurstöður könnunarinnar geta gefið tilefni til að vekja upp pá spurningu hvort sú grundvallarbreyting, sem felst í bví að miðað sé við pað að veita neytandanum val á pví að krefjast lagfæringar á gölluðum hlut eða að krefjast nýrrar afhendingar hafi komið nægilega skýrt fram í lagatextanum. Ekki eru fyrir hendi samsvarandi kannanir varðandi norskan eða íslenskan rétt, sem geta varpað ljósi á pá spurningu, hvort skýr tilgreining valréttar í lagatextum pessara landa hafi haft meiri áhrif á framkvæmd innan hverrar atvinnugreinar heldur en hinar dönsku reglur. 


\section{Skoðunargjald}

Að mjög miklu leyti hafa verið settar sömu reglur á Norðurlöndunum varðandi pá spurningu hvort atvinnurekandi eigi rétt á að innheimta gjald vegna skoðunar á söluhlut í pví skyni að sannreyna hvort söluhlutur sé gallaður. Réttarframkvæmdin í peim löndum par sem ekki hafa verið tekin upp ákvæði í lögum að pví er petta varðar (Danmörk, Finnland, Svípjóð) samsvarar efnislega peirri löggjöf sem sett hefur verið á öðrum Norðurlöndum (Ísland, Noregur).

Könnun á löggjöf og framkvæmd á Norðurlöndunum hefur leitt í ljós að atvinnurekandi getur ekki krafist greiðslu gjalds úr hendi neytanda vegna kostnaðar við að skoða söluhlut ef skoðunin leiðir í ljós að söluhlutur er gallaður. Neytandinn getur í slíkum tilvikum krafist pess að bætt verði úr göllum á söluhlut sér að kostnaðarlausu, sbr. 2. mgr. 3. gr. tilskipunar um neytendakaup. Atvinnurekandi á par af leiðandi eingöngu rétt á að krefjast greiðslu gjalds úr hendi neytanda í peim tilvikum, pegar skoðunin leiðir ekki í ljós galla. Sönnunarbyrðin fyrir pví að vara sé ekki gölluð hvílir á seljanda samkvæmt dönskum rétti. Petta kemur skýrt fram í réttarframkvæmd í Danmörku. Ekki er fyrir hendi réttarframkvæmd sem varpað getur ljósi á framkvæmdina að pví er petta varðar á hinum Norðurlöndunum nema að pví er Svíbjóð varðar. bar gildir ekki nein ákveðin regla um sönnunarbyrði varðandi galla að pví er tekur til pess hvort krefjast megi greiðslu fyrir skoðun á söluhlut. Рað virðist vera að par gildi almennar reglur um sönnunarbyrði pannig að í grunninn sé pað neytandinn sem sanna parf hvort fyrir hendi sé galli, pó svo krafan um sönnunarbyrði sé milduð.

Samkvæmt framkvæmd dönsku úrskurðarnefndarinnar um neytendamál gildir ennfremur sérregla um ábyrgðartilvik. begar um sérstaka ábyrgð er að ræða er hert á kröfum varðandi sönnun seljanda um að ekki sé fyrir hendi galli, sem hann ber ábyrgð á samkvæmt ábyrðarskírteini. Samsvarandi sérregla um ábyrgðir virðist ekki hafa próast á hinum Norðurlöndunum, pó svo seljandi beri samkvæmt 23. gr. sænsku neytendakaupalaganna almennt sönnunarbyrðina fyrir bví að galli sé ekki fyrir hendi pegar um ábyrgð er að ræða. Almennt gildir pó að einungis er hægt að krefjast greiðslu skoðunargjalds hafi svo verið um samið milli aðila í síðasta lagi á peim tíma pegar söluhlutur var afhentur til skoðunar. Samkvæmt sænskum rétti virðist vera að um ákveðið tímabil hafi verið fallist á að samningsákvæði sem fram koma á afhendingarmiða hafi verið nægileg til að fullnægja kröfum um sampykki. Dessi venja verður pó að teljast hafa verið afnumin samkvæmt nýrri úrskurði. Hér eftir eru gerðar sömu kröfur um framkvæmd ákveðins mats í hverju einstöku tilviki, e.t.v. með hliðsjón af afhendingarmiða innan allra Norðurlandanna. Atvinnurekandi á ekki undir neinum kringumstæðum rétt á pví að krefjast greiðslu skoðunargjalds ef skoðunin var ekki nauðsynleg til að sannreyna gallann. Ennfremur verður fjárhæð skoðunargjalds að vera sanngjörn. 
Skoðunargjaldið má par af leiðandi ekki vera í ósamræmi við pær skoðunarráðstafanir sem atvinnurekandi parf að framkvæma. 


\title{
8. Yhteenveto
}

\author{
Resumé - finsk
}

EU-DIREKTIIVI 1999/44/EY kulutustavaroiden kauppaa ja niihin liittyviä takuita koskevista tietyistä seikoista toi mukanaan joukon uusia, kulutustavaran kauppaa koskevia säännöksiä. Direktiivi edellytti muutosten tekemistä säännöksiin, jotka koskevat kulutustavaroiden kauppaa Pohjoismaissa. Direktiivin säännökset implementoitiin asianomaisilla laeilla, ja muutokset tulivat voimaan aikavälillä 2001-2003. Tämän raportin tarkoituksena on tutkia uusien säännösten soveltamista käytännön tilanteissa.

Raportissa keskitytään seuraavaan neljään ongelma-alueeseen: uuden olettamussäännön soveltamiseen, jonka mukaan minkä tahansa sopimuksenvastaisuuden, joka ilmenee tavarassa kuuden kuukauden kuluessa sen luovutuksesta, oletetaan olleen tavarassa jo luovutushetkellä; direktiiviin sisältyvään kahden vuoden valitusoikeutta koskevaan määräaikaan; kuluttajan oikeuteen vaatia myyjää vaihtamaan tai korjaamaan sopimuksenvastainen tavara, paitsi jos jompaakumpaa oikaisutapaa on pidettävä epäsuhtaisena; sekä kuluttajan oikeuteen vaatia tavaran saattamista sopimuksenmukaiseksi vastikkeetta suhteessa siihen menettelyyn, jossa tavaran virheellisyyden tutkimisesta saatetaan vaatia maksuja.

Koska kyseiset säännökset on saatettu voimaan vasta äskettäin, ratkaisukäytäntöä on ollut käytettävissä vain rajoitetusti. Olemme onnistuneet keräämään Pohjoismaiden Kuluttajavalituslautakunnista lähes 100 mainittuja asiakokonaisuuksia koskevaa päätöstä. Tässä raportissa keskitytään tarkastelemaan näitä päätöksiä.

\section{Olettamussääntö}

Direktiiviin sisältyvää olettamussääntö, jonka mukaan minkä tahansa sopimuksenvastaisuuden, joka ilmenee tavarassa kuuden kuukauden kuluessa sen luovutuksesta, oletetaan olleen tavarassa jo luovutushetkellä, on implementoitu lähes samoin sanamuodoin kaikissa tarkastelemissamme oikeusjärjestelmissä. Säännöstä on kuitenkin sovellettu jonkin verran eri tavoin eri oikeusjärjestelmissä. Kaikkein ”suorimmin” säännöstä voidaan todeta käytetyn Ruotsissa ja Norjassa. Kummassakin maassa säännöstä on käytetty arvioimatta millään tavoin, voiko kuluttaja osoittaa tai saattaa todennäköiseksi, että tavara on ollut sopimuksenvastainen jo luovutushetkellä. Tätä periaatetta sovelletaan nähdäksemme siitä riippumatta, minkälaisesta tuotteesta on kyse. Tanskassa ja Suomessa säännöstä on puolestaan käytetty eri tavalla. Molemmissa oikeusjärjestelmissä - kuitenkin selvemmin Tanskan oikeudessa - Kuluttajavalituslautakunta pyy- 
tää asiantuntijalausunnon sopimuksenvastaisuuden arvioimiseksi. Tämä muodostaa perustan sellaiselle näytön arvioinnille, joka on riippumaton olettamussäännöstä. Kummassakin oikeusjärjestelmässä säännöstä käytetään kuluttajan lisätukena, mikäli kuluttaja ei ole esittänyt riittävää näyttöä siitä, että tavara on ollut sopimuksenvastainen jo luovutushetkellä (Suomen lainsäädäntö); tai mikäli kuluttaja on saattanut todennäköiseksi, että tavara on ollut sopimuksenvastainen jo luovutushetkellä (Tanskan lainsäädäntö). Tanskan lainsäädännön mukaan sopimuksenvastaisuuden todennäköiseksi saattaminen ei kuitenkaan ole edellytys olettamussäännön käytölle. Säännöstä käytetään myös esimerkiksi sähkölaitteiden yhteydessä eli sellaisissa tapauksissa, joissa kuluttaja ei pysty osoittamaan tai saattamaan todennäköiseksi, että tavara oli sopimuksenvastainen jo luovutushetkellä, ja joissa samanaikaisesti ei ole perustetta päätellä, että sopimuksenvastaisuus ilmeni vasta myöhemmin. Asiantuntijalausuntojen käyttö Suomen ja erityisesti Tanskan oikeudessa merkitsee käytännössä sitä, että myyjällä on yleensä paremmat mahdollisuudet vapautua näyttötaakastaan kuin Norjan tai Ruotsin oikeudessa.

Kaikille tarkastelemillemme oikeusjärjestelmille on yhteistä se, että myyjän ei katsota olevan vastuussa tavaran sopimuksenvastaisuudesta, mikäli myyjä pystyy osoittamaan, että tavara ei ollut sopimuksenvastainen luovutushetkellä. Monissa tapauksissa myyjän esittämät vaatimukset hylätään sillä perusteella, ettei hän ole esittänyt tarvittavaa näyttöä. Toisissa tapauksissa taas katsotaan riittävän, jos myyjä pystyy saattamaan todennäköiseksi, että sopimuksenvastaisuus ilmeni vasta myöhemmin. On kuitenkin vaikea päätellä, onko näytön laatua koskevissa vaatimuksissa todellista eroa. Olemme löytäneet vain muutamia tapauksia, joissa myyjän on onnistunut vapautua vastuustaan. Tyypillisiä ovat tapaukset, joissa vaatekappaleita on käytetty ohjeiden vastaisella tavalla, sekä tapaukset, joissa eläimet ovat sairastuneet johonkin tautiin luovutuksen jälkeen. Sähkölaitteisiin liittyvissä tapauksissa myyjän on normaalisti vaikeaa vapautua todistustaakastaan. Matkapuhelimiin liittyvissä tapauksissa löysimme vain yhden esimerkin, jossa myyjän katsottiin vapautuneen todistustaakastaan. Normaalisti sellaisissa tapauksissa vaaditaan myyjää tukeva asiantuntijalausunto. Suomen ratkaisukäytäntöä tutkiessamme löysimme kuitenkin useita tapauksia, joissa myyjä vapautui vastuusta asiantuntijalausunnon puuttumisesta huolimatta. Tanskan oikeudessa on puolestaan mahdollista, että Kuluttajavalituslautakunta hylkää matkapuhelimiin liittyvän tapauksen vetoamalla näytön laatuun.

Olemme löytäneet vain muutamia tapauksia, jotka liittyvät siihen, että virheolettama on yhteen sopimaton tavaran tai virheen luonteen kanssa. Tätä käsitettä on sovellettu erityisesti tapauksissa, jotka liittyvät käytettyjen autojen ostoon ja myyntiin. Yksikään tapaus ei kuitenkaan osoita selvästi, että olettamussääntöä ei voitaisi soveltaa käytettyjen tavaroiden kaupassa. Tapaukset koskevat pääasiassa sitä, merkitseekö tavaran virheen luonne samalla yhteensopimattomuutta. Kahdessa matkapuhelimiin 
liittyvässä tapauksessa on kysymys siitä, merkitseekö kosteus- tai vesivahingon havaitseminen vasta pitkän ajan kuluttua tavaran luovutuksesta sitä, että virheen luonne on ristiriidassa olettamussäännön käytön kanssa. Jos kyseessä on vesivahinko, vastaus oli myöntävä (Ruotsin oikeus), jos kyseessä on kosteusvahinko, vastaus oli kielteinen (Norjan oikeus). Yhteensopimattomuuden käsitettä käytetään pääasiallisesti melko ylimalkaisesti. Tämä merkitsee sitä, että yhteensopimattomuuteen liittyvien tapausten ja sellaisten tapausten välillä, joissa myyjä on osoittanut esimerkiksi tavaraa käytetyn väärin, ei ole selvää eroa.

Mitä tulee siihen, kuinka säännön käyttöä tunnetaan elinkeinoelämässä, olemme löytäneet kaksi tanskalaista raporttia, joiden johtopäätökset näyttävät olevan erisuuntaisia. CBS:n raportissa päädytään siihen, että olettamussääntö on vaikuttanut käytäntöön aiottua tai odotettua enemmän; Kuluttajavalituslautakunta puolestaan toteaa raportissaan, että olettamussääntö tunnetaan melko huonosti.

\section{Myyjän vastuuta koskeva aikaraja}

Direktiivin myötä otettiin käyttöön kahden vuoden vastuuaika tavaran luovutushetkestä lukien. Määräajalla oli konkreettinen vaikutus ainoastaan Tanskassa ja Islannissa, kun taas muissa pohjoismaissa oli jo käytössä joko kahden tai viiden vuoden määräaika tai määräaikaa ei lainkaan ollut. Ruotsin oikeudessa kahden vuoden määräaika pidennettiin kolmeksi vuodeksi vuonna 2005.

Mitä tulee kysymykseen todistustaakasta ja näytöstä kuuden kuukauden määräajan päättymisestä kahden vuoden määräaikaan saakka totesimme, että Tanskan, Norjan ja Ruotsin lainkäyttöviranomaiset pitävät lähtökohtana sitä, että kuuden kuukauden määräajan umpeuduttua kuluttajan on osoitettava sopimuksenvastaisuuden olleen olemassa jo luovutushetkellä ja että kyse siten oli tavaran virheestä. Kuitenkin sekä Norjan että Ruotsin oikeudessa todisteiden esittämistä koskevat vaatimukset ovat kuluttajan kannalta katsottuna suhteellisen lieviä. Norjan lainsäädännön perusteella näyttää siltä, että vaatimus myyjän näyttövelvollisuudesta suosii olettamussäännön käyttöä kuluttajan hyväksi kuuden kuukauden määräajan päättymisen jälkeen. Tämä ilmenee erityisesti tapauksista, joissa sovelletaan viiden vuoden määräaikaa valitusoikeudelle. Ellei osoiteta vian johtuvan siitä, että kuluttaja on käyttänyt tavaraa väärin, kuluttajan on katsottu osoittaneen, että tavara on ollut sopimuksenvastainen jo luovutushetkellä. Ruotsin oikeudessa erotetaan tilanteet, joissa on annettu takuu tilanteista, joissa siitä ei ole annettu. Jos myyjä on myöntänyt tavaralle takuun, myyjän on osoitettava virheen johtuvan siitä, että kuluttaja on käyttänyt tavaraa väärin. Tapauksissa, joissa tavaralle ei ole myönnetty takuuta, näyttövelvollisuus on kuluttajalla. Kuluttajan näyttövelvollisuus on tosin lievempi siinä mielessä, että näytöksi riittää Kuluttajavalituslautakunnan toteamus siitä, että kuluttajan kuvaus on uskottavampi kuin myyjän kuvaus. Sen paremmin Norjan kuin Ruotsinkaan lainsää- 
dännössä ei näytä tapahtuneen yleiseen käytäntöön vaikuttavia muutoksia olettamussäännön käyttöönoton jälkeen. Norjassa ratkaistu tapaus tältä alueelta on edelleen Rt 1998.716; Ruotsissa kirjallisuudessa viitataan edelleenkin yllä kuvattuihin, 1990-luvun alkupuolella ratkaistuihin tapauksiin. Tanskan lainsäädännön perusteella tilannetta on sen sijaan vaikeampi arvioida. Tanskassa Kuluttajavalituslautakunnan hankkiman asiantuntijalausunnon luonne on ratkaiseva. Lähtökohtana on, että vain jos lausunto tukee kuluttajaa, asia ratkaistaan hänen edukseen. Jos asiantuntijalausunto sen sijaan tukee myyjää yhtä paljon kuin kuluttajaa, näyttövelvollisuus on kuluttajalla, paitsi tietyissä erityisolosuhteissa, esim. jos kuluttaja on ilmoittanut tavaran sopimuksenvastaisuudesta pian kuuden kuukauden määräajan päättymisen jälkeen. Kaiken kaikkiaan - toisin kuin lain esitöissä oletettiin - Tanskan lainsäädäntö näyttää asettavan melko ankarat vaatimukset kuluttajan näyttövelvollisuudelle kuuden kuukauden määräajan päättymisen jälkeen. Eri oikeusjärjestelmien väliset erot näyttävät johtuvan varsinkin siitä, että Tanskassa asiantuntijalausunnot hankkii Kuluttajavalituslautakunta, kun taas Norjassa ja Ruotsissa kuluttaja ja myyjä ovat kumpikin velvollisia hankkimaan kyseiset lausunnot.

Mitä tulee "valitusoikeusongelmaan", toisin sanoen tilanteeseen, jossa myyjän valitusoikeus eli oikeus ilmoittaa tavaran sopimuksenvastaisuudesta valmistajalle on kestoltaan lyhyempi kuin kuluttajan oikeus ilmoittaa tavaran sopimuksenvastaisuudesta myyjälle, kaikkien Pohjoismaiden paitsi Suomen oikeusjärjestelmissä ongelma on siinä, että eri osapuolilla saattaa olla eripituinen oikeus ilmoittaa sopimuksenvastaisuudesta. Tanskassa tehty empiirinen tutkimus tukee sitä tosiasiaa, että valitusoikeuden kesto todellakin vaihtelee. On kuitenkin vaikea päätellä, missä määrin tämä aiheuttaa ongelmia käytännössä. Joistakin päätöksistä käy ilmi, että myyjän oikeutta valittaa sopimuksenvastaisuudesta valmistajalle on käsitelty tapauksen yhteydessä, mutta tarkastelumme kohteena olleet ratkaisut eivät osoita, että myyjä pitäisi omaa oikeuttaan valittaa sopimuksenvastaisuudesta olennaisena kriteerinä silloin, kun on kysymys kuluttajan oikeuksista myyjään nähden. Tämä ei kuitenkaan sulje pois sitä mahdollisuutta, että tällaista argumenttia käytetään vähittäiskaupassa.

\section{Oikaisun epäsuhdan arviointi}

Oikaisun epäsuhtaa koskeva kriteeri direktiivin artiklassa 3.-(3) on toteutettu Pohjoismaissa lähes tulkoon identtisesti. Mitä tulee olemassa oleviin eroihin, mainitsemme ensin Norjan ja Islannin kansallisiin säännöksiin sisältyvän painotuksen koskien kuluttajan valintaoikeutta oikaisuun nähden; toiseksi Ruotsin lainsäädännössä on toteutettu "neljäs kriteeri”, jonka mukaan on harkittava, onko kuluttajan valitsemaa oikaisua pidettävä epäsuhtaisena verrattuna vaihtoehtoiseen oikaisuun, joka olisi toteutettavissa oleellisesti pienemmin kustannuksin. Nämä yksityiskohtiin liittyvät erot heijastuvat jossain määrin myös ratkaisukäytäntöihin. Ainoatakaan 
käytännön esimerkkiä ei kuitenkaan löytynyt tilanteesta, jossa kuluttaja pitää tavaran korjaamista sopimuksenmukaiseksi parempana vaihtoehtona kuin sitä, että myyjä vaihtaa tavaran virheettömään. Sen vuoksi jatkossa keskitytään tilanteeseen, jossa kuluttaja pitää tavaran vaihtoa parempana vaihtoehtona kuin sen korjaamista.

Mitä tulee kriteeriin, jonka mukaan vaihtoa on pidettävä epäsuhtaisena verrattuna kustannuksiin, jotka aiheutuvat tavaran saattamisesta sopimuksenmukaiseksi, Tanskan ja Norjan käytäntö osoittaa, että vaihtokustannukseksi määritellään myyjän hankintahinta. Vaikuttaa siltä kuin ainoastaan Tanskan Kuluttajavalituslautakunta olisi korostanut sitä, että tulee myös harkita, missä määrin myyjä voi markkinoida kyseistä tavaraa myöhemmin käytettynä tavarana.

Mitä tulee "tavaran arvoa” koskevaan kriteeriin, ratkaisukäytäntö Tanskassa ja Norjassa osoittaa, että tavaran alhainen arvo viittaa vaihtoon. Myös lain esityöt tukevat tätä olettamusta. Sitä vastoin ei ole selvää, miten arvioidaan sitä, onko kyse korkeasta vai matalasta arvosta.

"Virheen merkitystä" koskevaa kriteeriä arvioidaan Norjan oikeudessa sen perusteella, onko virhe olennainen tavaran toimivuuden kannalta.

Mitä tulee kriteeriin "aiheuttamatta kuluttajalle huomattavaa haittaa”, käytäntö Tanskassa ja Norjassa osoittaa ratkaisun perustuvan siihen, kuinka nopeasti virhe voidaan oikaista, onko tavara oikaisun jälkeen edelleen virheellinen kosmeettisia vikoja lukuun ottamatta ja onko kuluttajan vaikea tulla toimeen ilman kyseistä tavaraa.

Käytäntö osoittaa niin ikään, että direktiivissä mainitun kolmen kriteerin lisäksi sovelletaan myös muita kriteerejä arvioitaessa sitä, onko vaihtoa pidettävä epäsuhtaisena oikaisuna.

Ruotsin oikeuden mukaan ratkaisevaa on se, onko tavaran vaihtaminen myyjälle olennaisesti kalliimpi vaihtoehto kuin sen korjaus ("Ruotsin kruunu Ruotsin kruunulta - periaate"). Koska tätä periaatetta sovelletaan ainoastaan Ruotsin oikeudessa, mutta ei muiden Pohjoismaiden, heijastaa tämä oletettavasti sitä, että kyseinen periaate on nimenomaisesti kirjoitettu Ruotsin lainsäädäntöön. Tässä yhteydessä on mielenkiintoista todeta, että Norjan laamannioikeuden ratkaisemissa tapauksissa tämän kriteerin käyttö on nimenomaisesti hylätty. Sen vuoksi päättelemme, että vaihdon vaatiminen on todennäköisesti vaikeampaa Ruotsin kuin Norjan oikeuden perusteella.

Tunnusomainen piirre Norjan oikeudelle on se, että sekä lain esitöissä että tuomioistuinratkaisuissa on otettu huomioon myös ympäristönäkökohdat. Ei kuitenkaan ole selvää, millainen merkitys ympäristönäkökohdilla on silloin, jos ympäristönäkökohdat puhuvat yksiselitteisesti tavaran vaihtamisen puolesta; sekä pitäisikö myös tehdä erottelu eri tavaralajien osalta ja kiinnittäen huomiota siihen, onko kyse yksittäisen tavaran vai koko tavarasarjan vaihtamisesta.

Pohjoismaiden ratkaisukäytännöt osoittavat epäsuhtaisen oikaisun arvioinnin olevan merkityksellistä paitsi korjaamis- ja vaihtamisoikeuden 
välisessä suhteessa myös silloin kun kyse on korjaamisesta ja asianmukaisesta hinnanalennuksesta tai korjaamisesta ja sopimuksen purkamisesta.

Vallitseva oletus on, että nimenomaan myyjän on esitettävä riittävä näyttö kuluttajan valitseman oikaisun epäsuhtaisuudesta. Tämä kuvastaa sitä, että direktiivin pääsääntö, jonka mukaan nimenomaan kuluttaja valitsee oikaisun, on toteutettu myös niissä oikeusjärjestelmissä, joissa sitä ei ole lakitekstin sanamuodossa todettu. Tämä näkyy myös Tanskan Kuluttajavalituslautakunnan ratkaisukäytännöstä, jossa - vaikka lakitekstissä asiaa ei mainita - ratkaisujen perusteluissa usein todetaan, että kuluttajalla on valintaoikeus oikaisutavan suhteen.

Sen paremmin direktiivissä kuin eri Pohjoismaiden kansallisissa säännöksissäkään ei velvoiteta myyjää informoimaan kuluttajaa tämän valintaoikeudesta suhteessa oikaisua koskeviin sääntöihin. Siitä huolimatta käytäntö osoittaa, että tällaisen informaation antamatta jättäminen saattaa osoittautua haitalliseksi myyjän kannalta.

Yhteenvetona päättelemme, että vaikka epäsuhtaisen oikaisun arviointi perustuu Pohjoismaissa hieman toisistaan poikkeaviin kriteereihin, yleiskuva osoittaa lakia soveltavien viranomaisten olevan hyvin tietoisia siitä, että oikaisun arvioinnin tulee kuvastaa kuluttajan eduksi tehtyä muutosta, mikä olikin uuden säännöksen tarkoitus.

Ihannetapauksessa tämän säännösten tulkinnan pitäisi tulla ilmi myös säännöksiä eri elinkeinoelämän aloilla sovellettaessa. Asiaa tutkittiin CBS:n toimesta Tanskassa vuonna 2005. Raportin johtopäätöksen mukaan 2/3 vastaajista ei katsonut säännöksellä olleen minkäänlaista vaikutusta, kun taas 1/3 vastaajista katsoi sillä olleen toivotun, joskin intensiteetiltään vaihtelevan suuruisen vaikutuksen. Raportin tulokset nostavat esille kysymyksen, onko perustavaa laatua olevaa muutosta, siis kuluttajalle annettua oikeutta valita korjauksen ja vaihdon välillä, korostettu riittävästi kansallisissa lainsäädännöissä. Norjasta tai Islannista ei ole vastaavia raportteja, jotka voisivat antaa vastauksen kysymykseen, onko kuluttajan valintaoikeuden korostaminen näiden kahden maan kansallisessa lainsäädännössä vaikuttanut liiketoimintatapaan enemmän kuin Tanskassa sovellettavat säännöt ovat vaikuttaneet.

\section{Tavaran tutkimista koskevat maksut}

Kysymys myyjän oikeudesta vaatia korvausta tavaran tutkimisesta mahdollisen sopimuksenvastaisuuden toteamiseksi, on toteutettu Pohjoismaissa yhtenevästi. Oikeuskäytäntö niissä maissa, joissa ei ole tätä asiaa koskevia säännöksiä (Tanska, Suomi ja Ruotsi), on siten yhteneväinen niiden säännösten kanssa, joita on muissa Pohjoismaissa (Islanti ja Norja).

Säännöksistä ja sovelletusta käytännöstä tekemiemme havaintojen perusteella olemme tulleet siihen johtopäätökseen, että myyjällä ei missään Pohjoismaissa ole oikeutta vaatia kuluttajaa korvaamaan tavaran tutkimisesta aiheutuneita kuluja, mikäli tutkimus osoittaa tavaran olevan sopi- 
muksenvastainen. Jos tavara on sopimuksenvastainen, kuluttajalla on oikeus saada se saatetuksi sopimuksenmukaiseksi vastikkeetta, vrt. direktiivin artikla 3.-(2). Myyjä voi siten vaatia kuluttajalta korvausta ainoastaan sellaisissa tapauksissa, joissa tutkimus ei osoita tavaran olevan sopimuksenvastainen. Tanskan oikeuden mukaan myyjä on velvollinen osoittamaan tavaran olevan sopimuksenmukainen. Tämä käy selvästi esille Tanskan oikeuskäytännöstä. Emme ole löytäneet ainoatakaan käytännön tapausta, joka valaisisi muiden Pohjoismaiden käytäntöä, paitsi Ruotsista. Näyttää siltä, että Ruotsissa ei ole erityistä näyttövelvollisuutta koskevaa säännöstä, jota sovellettaisiin tutkimuksesta perittäviin korvauksiin. Vaikuttaakin siltä, että tällöin sovelletaan näyttövelvollisuutta koskevaa standardisäännöstä siten, että kuluttajan on osoitettava tavaran sopimuksenvastaisuus, vaikkakin näyttövelvollisuus on lievennetty.

Tanskan Kuluttajavalituslautakunnan käytäntö osoittaa lisäksi takuun yhteydessä sovelletun erityissääntöä. Tällaisissa tapauksissa näyttövelvollisuuden vaatimuksia on myyjän osalta laajennettu siten, että myyjän on osoitettava, ettei kyse ole tavaran virheestä, josta myyjä vastaa antamansa takuun perusteella. Muissa Pohjoismaista ei ole kehitetty vastaavaa takuuta koskevaa erityissääntöä, joskin Ruotsin kuluttajakauppaa koskevan lain (konsumentköplag) 23 §:n mukaan myyjällä on takuun yhteydessä lähtökohtaisesti näyttövelvollisuus siitä, ettei tavara ole virheellinen. Yleisesti on kuitenkin voimassa sääntö, jonka mukaan korvausta voidaan vaatia vain, mikäli siitä on sovittu osapuolten kesken viimeistään silloin, kun tavara on luovutettu tutkittavaksi. Huomasimme, että Ruotsin oikeuden mukaan erässä vaiheessa katsottiin riittäväksi osoitukseksi sopimuksesta tavaran luovuttamisen yhteydessä annetussa kuitissa olleet sopimusehdot. Kuitenkin eräs äskettäin annettu päätös osoittaa käytännön muuttuneen. Vastedes tullaankin meidän arviomme mukaan kaikissa Pohjoismaissa soveltamaan tältä osin samantyyppisiä vaatimuksia, kun tapauksia käytännössä arvioidaan. Myyjällä ei missään olosuhteissa ole oikeutta vaatia korvausta, jos tutkimus ei ole ollut välttämätön sopimuksenvastaisuuden toteamiseksi. Vaadittavan korvauksen tulee lisäksi olla kohtuullinen. Tämä merkitsee sitä, että korvaus ei saa olla epäsuhtainen, kun sitä verrataan myyjän tekemiin tutkimustoimenpiteisiin nähden. 



\section{Abstract}

Resumé - engelsk

The EU DIRECTIVE 1999/44/EF on certain aspects of the sale of consumer goods and associated guarantees introduced a number of new provisions regarding consumer sale. The directive necessitated changes in the provisions regarding consumer sale in the Nordic countries. The provisions of the directive were implemented in the relevant acts and the changes came into force in the period from 2001 to 2003. The purpose of this report is to examine the use of the new provisions in actual practice.

The report focuses on four problematic areas: the use of the new presumption rule, under which any lack of conformity, which becomes apparent within six months of delivery of the goods shall be presumed to have existed at the time of delivery; the directive's two-year right of complaint; the entitlement of the consumer, in the case of a lack of conformity, to require the seller to replace the goods or repair them, unless one of these remedies are disproportionate; as well as the entitlement of the consumer to have the goods brought into conformity free of charge compared with actual practice regarding the claim of fees.

Since these provisions have only been implemented recently, actual practice is limited. We have succeeded in collecting approx. 100 decisions from Consumer Complaints Boards in the Nordic countries, which illustrates the focus areas. These decisions are the subjects of examination in this report.

\section{The Presumption Rule}

The presumption rule in the directive, under which any lack of conformity which becomes apparent within six months of delivery of the goods shall be presumed to have existed at the time of delivery, has been implemented almost word-for-word in the provisions of the legal systems we have examined. Still, the provision is used in different ways in the legal systems we have examined. The most "direct" use of the provision is found in Sweden and Norway. In Sweden and Norway, respectively, the provision is used without any assessment of whether the consumer can prove or render probable, that the lack of conformity existed at the time of delivery. As far as we can see, this provision is used regardless of the nature of the goods. In Denmark and Finland, respectively, the provision is used in a different way. In both these countries - yet most distinctly under Danish law - The Consumer Complaints Board will ask for an expert's opinion to assess any lack of conformity. This forms the basis for an evaluation of the evidence, which is independent of the presump- 
tion rule, and both legal systems are characterised by the use of this provision as an extra support on the part of the consumer, if the consumer has not produced sufficient evidence to prove lack of conformity at the time of delivery (Finish law); or if the consumer has rendered probable that the lack of conformity existed at the time of delivery (Danish law). Danish law shows, that rendering probable lack of conformity is not a condition for using the presumption rule. For example, the provision is also used in cases involving electrical goods, where the consumer can not prove or render probable, that the lack of conformity existed at the time of delivery, and, at the same time, where there is no basis for concluding that the lack of conformity occurred at a later point in time. The use of expert opinions under Finish and Danish law means, that the seller stands a better chance of lifting the burden of proof in actual practice in these countries than in Norway or Sweden.

In all the legal systems we have examined, the seller is not held liable for lack of conformity if the seller can prove that the lack of conformity did not exist at the time of delivery. In many cases, claims made by the seller are dismissed, because the seller has not produced sufficient evidence. In other cases, it is enough if the seller can render probable, that the lack of conformity occurred at a later point in time. However, it is difficult to conclude, whether there is a real difference in requirement regarding the standard of proof. We have only found a few cases in which the seller is not held liable for lack of conformity. Typical cases involve article clothing being used in a way that does not meet specifications, and animals that have contracted a disease after delivery. In cases involving electrical goods, it is often very difficult for the seller to sustain the burden of proof. In cases involving cell phones, we have only found one case in which the seller sustained the burden of proof. Under normal circumstances, such cases require that an expert's opinion exists, which supports the seller. However, under Finish law, we found a number of cases in which the seller was not held liable for lack of conformity despite the fact that an expert's opinion did not exist. Under Danish law, The Consumer Complaints Board can dismiss cases involving cell phones with reference to the standard of proof.

We have only found a few cases concerning the concept of incompatibility. This concept has been applied in cases concerning buying and selling of second-hand cars in particular. However, none of the cases clearly states, that the presumption rule can not be used in cases involving second-hand goods. The cases are primarily about whether the nature of non-conformity means that incompatibility exists. Two cases involving cell phones are about the question of whether the fact that damage by damp or water, respectively, is discovered long time after the time of deliver means, that the nature of non-conformity is incompatible with the use of the presumption rule. If water damage exists, this is confirmed (under Swedish law), if damage by damp exists, this is not confirmed 
(under Norwegian law). The concept of incompatibility is primarily used in less absolute terms. This means, that there is no clear distinction between cases involving incompatibility and cases in which the seller has proved, for example, misuse of the goods.

When it comes to the knowledge of how the provision is used in actual practice, we have found two Danish reports, which seem to point in different directions. A report from CBS, arrive at the conclusion, that the presumption rule as such is found to have a larger impact in actual practice than it was intended and expected; a report from The Consumer Complaints Board arrive at the conclusion that figures show that there is a widespread lack of knowledge about the presumption rule.

\section{The Right of Complaint Period}

The directive introduced a two-year right of complaint from the time of delivery. The time limit did only have a tangible effect in Denmark and Iceland, in that the other Nordic countries did already have a two-year or a five-year right of complaint or no limitation of right of complaint, respectively. In 2005, the two-year right of complaint has been extended to a three-year right of complaint under Swedish law.

Regarding the question of burden of proof and probativeness in the period from the expiry of the six month period to the two-year right of complaint, we found, that in the legal systems of Denmark, Norway and Sweden actual practice shows, that after the expiry of the six months period the consumer must prove that non-conformity existed at the time of delivery and that this represents a defect. However, under Norwegian as well as Swedish law the formal requirements regarding the production of evidence on the part of the consumer are relatively lenient. Under Norwegian law, it seems as if the requirement on the seller to sustain the burden of proof favours the use of a presumption rule for the benefit of the consumer after the expiry of the six months period. This is particularly seen in cases involving the five-year right of complaint. Unless it is proved that the defect is due to the consumer's misuse of the goods, the consumer is found to have proved that the lack of conformity existed at the time of delivery. Under Swedish law, a distinction is made between cases where a guarantee concerning the goods has been provided and other cases. In cases where the seller has provided a guarantee concerning the goods, the seller must prove that the defect was caused by misuse on the part of the consumer. In cases where a guarantee concerning the goods has not been provided, the burden of proof lies with the consumer, however, this burden is relaxed, in that it is sufficient that the Complaints Board finds that the consumer's representation is more probable than the seller's representation. Neither Norwegian nor Swedish law seem to show a change in actual practice after the implementation of the presumption rule. In Norway, the decided case in this field is still Rt 1998.766; under Swedish law, references made in the literature are still to the decided 
cases described above from the early 1990ies. It is more difficult to evaluate the situation under Danish law. In Denmark, the nature of the expert's opinion obtained by The Consumer Complaints Board is decisive. Only in cases where the expert's opinion supports the consumer, the court finds for the consumer. If the expert's opinion supports the seller to the same degree as it supports the consumer, the burden of proof lies with the consumer, in that the consumer must sustain the burden of proof, unless special circumstances apply, e.g. if the consumer has given notice of lack of conformity shortly after the expiry of the six months limitation period. All in all - contrary to what was expected - there seem to be rather strict demands on the consumer's burden of proof after the expiry of the six months limitation period under Danish law. The differences between the legal systems are most pronounced when it comes to the use of expert opinions; in Denmark these are obtained by The Consumers Complaints Board, while it is up to the consumer and seller, respectively, to obtain such opinions under Norwegian and Swedish law.

Regarding the "right of complaint dilemma", i.e. the situation where the seller's duration of right of complaint for notice of lack of conformity towards the producer is shorter than the consumer's duration of right of complaint for notice of lack of conformity towards the seller, all the legal systems of the Nordic countries, except for the Finnish legal system, this problem exists in that the duration of right of complaint for notice of lack of conformity may vary for the parties involved. The empirical study in Denmark supports the fact that the duration is in fact different. However, it is difficult to conclude to which extent this causes problems in actual practice. From some decisions it appears that the seller's right to claim lack of conformity towards the producer has been an issue in the case, but the actual practice that we have examined does not show, that the seller considers his own right to claim lack of conformity to be a relevant criteria when it comes to the question of the consumers rights towards the seller. However, this does not exclude that such an argument be used in actual practice in retail trade.

\section{Evaluation of Disproportionate Remedy}

The criterion concerning disproportionate remedy in article 3.-(3) of the directive has been implemented identically in the Nordic countries. Regarding the differences that do exist, we will first mention the accentuation in the provisions of Norwegian and Icelandic national law concerning the consumers choice concerning remedy; second, under Swedish law, a "fourth criterion" has been implemented, that states that it must be considered whether the remedy chosen by the consumer is deemed to be disproportionate, in comparison with an alternative remedy, which may be effectuated at a substantially lower cost. These differences in details are to some extent reflected in actual practice. There is no actual practice on the situation where the consumer prefers to have the goods brought 
into conformity instead of the seller replacing the goods. Below, the focus is, therefore, on the situation where the consumer prefers replacement over having the goods brought into conformity.

With regard to the criterion under which replacement shall be deemed to be disproportionate, in comparison with the cost of having brought the goods into conformity, Danish and Norwegian actual practice shows that the cost of replacement are defined as the seller's purchase price. It seems as if it is only the Danish Consumers Complaints Board which in actual practice has emphasised that it must also be considered whether the goods in question can be reused by the seller as second-hand goods.

With regard to the criterion of "the value of the goods", actual practice in Denmark and Norway shows that a low value of the goods point towards replacement. This is supported by the legislative material. However, a clear definition of how to evaluate whether a value is high or low does not exist.

As for the criterion "the significance of the lack of conformity", Norwegian actual practice focuses on whether the lack of conformity is significant taking into account the nature of the goods.

As for the criterion "without significant inconvenience to the consumer", actual practice in Denmark and Norway shows, that the decision rests on whether the remedy of the lack of conformity can been completed within a reasonable time, and if the goods after the remedy will continue to be faulty beyond cosmetic faults, and if it is difficult for the consumer to do without the goods.

Actual practice also shows that in addition to the three criteria mentioned in the directive other criteria are also applied in the evaluation of whether replacement is a disproportionate remedy.

It is a distinctive feature of Swedish law that it is decisive whether replacement will be much more costly for the seller than repair ("the Swedish krone by Swedish krone -principle”). Since this principle is used under Swedish law and not in any of the other Nordic countries, we find that it is due to the fact that the principle has in fact been implemented in the provisions of the Swedish national law. In this connection, it is interesting to notice, that the decided cases of the Norwegian Lagmannsrett dismiss the direct use of this criterion. Therefore, we conclude that it will probably be more difficult to claim replacement under Swedish law that under Norwegian law.

It is a distinctive feature of Norwegian law that legislative material as well as decided cases have also focused on environmental considerations. Yet it is not clear, which role such considerations play, and whether environmental considerations speak in favour of replacement; and whether the nature of the goods should be considered; and whether replacement is only relevant for single goods or series of goods.

Actual practice in the Nordic countries also illustrates, that the evaluation of disproportionate remedy may be relevant not only when it comes 
to repair or replacement, but also when it comes to repair and appropriate reduction of the price or repair and having the contract rescinded.

The predominant assumption is, that it the seller who must provide sufficient evidence that the remedy, which the consumer selects, is disproportionate. This shows that the provision of the directive stating that it is the consumer who chooses the remedy, has in fact been implemented in the legal systems, even though this has not been accentuated in the text. This can also be seen in the actual practice of The Consumer Complaints Board in Denmark, where the ratio decidendi states that it is the consumer who chooses the remedy - even though it is not accentuated in the provisions.

Neither the directive nor the provisions of national law in the Nordic countries state, that the seller is under obligation to inform the consumer of his choice of remedy as stated in the provisions. Still, actual practice shows that lack of information on the part of the seller may be at a disadvantage to the seller.

Summing up, we conclude, that even though the evaluation of disproportionate remedy is based on slightly different criteria in the Nordic countries, the overall picture shows that the authorities that apply the law are well aware, that the evaluation of remedy must reflect the change in favour of the consumer, which was the purpose of the new provision.

Ideally, this interpretation of the provisions should be represented in actual practice. In the 2005 report from CBS, this has been researched in Denmark. The conclusion in the report shows, that $2 / 3$ of the respondents did not find that that the provision had had any effect, while $1 / 3$ of the respondents found that it had had the desired effect, even though the intensity did vary. The report's results give rise to the question, whether the fundamental change with regard to granting the consumer the right to choose between repair and replacement has been sufficiently accentuated in the provisions of the national law. There are no similar reports from Norway or Iceland that can answer the question: to which degree has the accentuation of consumer choice in the provisions of the national laws of these two countries influenced business behaviour compared to Denmark.

\section{Claim of Fees}

The provisions regarding whether a seller is entitled to claim a fee for an examination of goods with a view to establishing if the goods is nonconforming, are implemented similarly in the Nordic countries. Actual practice in the countries without provisions regulating this issue (Denmark, Finland and Sweden) is similar to actual practice in other Nordic countries (Iceland and Norway) where the provisions have been implemented.

On the basis of our findings regarding provisions and actual practice, we conclude, that a seller in none of the Nordic countries is entitled to claim a fee from the consumer to cover any costs incurred in connection 
with the examination of the goods, provided that the examination shows that the goods are non-conforming. In the case of lack of conformity, the consumer shall be entitled to have the goods brought into conformity free of charge, cf. article 3.-(2) of the directive. The seller can, therefore, only claim a fee from the consumer in cases where the examination of the goods does not show non-conformity. Under Danish law, the burden of proof regarding the goods being in conformity with the contract lies with the seller. This is clear from actual practice in Denmark. We have not found any actual practice to illustrate actual practice in the other Nordic countries, except from Swedish law. In Sweden, a provision regarding the burden of proof does not seem to exist when it comes to the question of whether a fee can be claimed. It seems as if the standard provision regarding the burden of proof is used, in that it is the consumer, who must prove, that the goods are non-conforming, even though the burden of proof has been relaxed.

The actual practice of the Danish Consumers Complaints Board shows use of specific provisions in cases involving a guarantee. In cases involving a guarantee, the requirements on the burden of proof on the part of the seller are extended, in that he must sustain that the goods does not lack conformity, for which he is liable under the guarantee. A similar special provision in cases involving a guarantee has not been found in the other Nordic countries, even though, under article 23 of the Swedish konsumentköplag, it is for the seller to prove that the goods are in conformity. We have found, that in general a fee can only be claimed if this was agreed upon between the parties at the time when the goods was handed over for examination at the latest. Under Swedish law, we found that at some point it was recognized that the acceptance of a receipt for delivery for examination was sufficient to prove agreement. However, a recent decision shows that actual practice has changed. It is our evaluation, that hereinafter similar requirements for a specific evaluation in every single case where goods have been handed over for examination will be applied in all the Nordic countries. Under no circumstances is the seller entitled to claim a fee if the examination was not necessary to establish the lack of conformity. Further, the fee claimed must be reasonable. This means, that the fee must not be disproportionate in comparison with the evaluation measures being initiated by the seller. 



\title{
Bilag: Samlet oversigt over retspraksis
}

\author{
I Formodningsreglen
}

Dansk ret:

1.

Sag 2002-62/7-89

En læderlap, der var en væsentlig del af en skodesign, faldt af inden for den første måned efter købet. Forbrugerklagenævnet fandt det sandsynliggjort, at læderlappen ikke havde været tilstrækkeligt fastgjort ved skoens fabrikation. Sælgeren havde herefter ikke afkræftet formodningen for, at kvalitetsafvigelsen havde været til stede på leveringstidspunktet. Skoene var derfor mangelfulde ved leveringen, og da manglen var væsentlig kunne købet af skoene hæves.

2.

Sag 2002-521/7-1568

En forbruger, A, købte i april 2002 en bil, som blev synet efter køb. Bilen blev ikke godkendt på grund af flere sikkerhedsmæssige fejl. A reklamerede over fejlene og gjorde derudover gældende, at der var et stenslag i forruden, som ikke havde været der, da hun prøvekørte bilen. Den erhvervsdrivende, B, afviste kravene, hvorefter A indbragte sagen for Forbrugerklagenævnet. Forbrugerklagenævnet udtalte, at da et stenslag i en forrude er en typisk brugsomstændighed, og da det ikke var nævnt i synsrapporten udarbejdet efter leveringen, var der ikke grundlag for at formode, at stenslaget var til stede på leveringstidspunktet. A kunne derfor ikke fremsætte krav mod B angående stenslaget. Derimod var A berettiget til at påberåbe sig de sikkerhedsmæssige fejl som køberetlige mangler. Da den sagkyndige havde vurderet, at disse fejl forelå på leveringstidspunktet at, og at det ville koste ca. kr. 9.000 at afhjælpe de konstaterede sikkerhedsmæssige mangler, fandt nævnet, at A var berettiget til et rimeligt afslag i købesummen, der blev fastsat til kr. 9.000. Nævnet fandt ikke, at B havde pligt til at betale A’s udgifter ved et nyt syn.

3.

Sag 2002-521/7-88

En forbruger, A, købte i juni 2002 en brugt bil, som 2 måneder efter leveringen på et tidspunkt, hvor A havde kørt ca. 3.000 km., brød i brand og udbrændte. A klagede til den erhvervsdrivende, B, som afviste A's klage, idet han ikke mente, at A havde bevist, at der var tale om en fejl, der havde været til stede på leveringstidspunktet, og at A i øvrigt burde have bemærket de symptomer, der måtte have været forud for branden, og have reageret på dem. A indbragte herefter sagen for Forbrugerklagenævnet. Forbrugerklagenævnet udtalte for det første, at det forhold, at bilen var købt som beset og afprøvet og med oplysning om, at diverse fejl og mangler kunne forekomme, ikke afskar A fra at gøre mangelindsigelser gældende, hvis bilen ved leveringen havde ikke-forventelige fejl, såsom fejl af sikkerhedsmæssig karakter. Den af nævnet udpegede sagkyndige fandt, at branden 
med overvejende sandsynlighed opstod i anledning af, at en benzinslange var flækket på grund af mørning, og nævnet konstaterede herefter, at der var tale om en sikkerhedsmæssig fejl, som ikke var opstået pludseligt, hvorfor det fandtes sandsynligt, at slangen havde været defekt allerede på leveringstidspunktet. Da klageren ikke havde afkræftet formodningen for, at manglen forelå allerede på leveringstidspunktet, fandt nævnet, at købet kunne hæves, selvom bilen ikke kunne tilbageleveres i væsentlig samme stand, idet dette skyldtes bilens egen beskaffenhed på leveringstidspunktet.

En forbruger, A, købte et par spidssnudede sko, hvor overlæderet efter kort tids brug var slidt. A reklamerede til den erhvervsdrivende, B, efter tre dage. B afviste klagen, hvorfor A indbragte sagen for Forbrugerklagenævnet. Forbrugerklagenævnet fandt, at skoenes specielle design indebar en risiko for, at de lange tånæser kunne beskadiges ved almindelig brug. Da skaden måtte antages at skyldes, at skoene havde været udsat for brug, som de ikke var egnede til, havde B afkræftet formodningen for, at der skulle foreligge fabrikations- eller materialefejl, hvilket intet tydede på. Følgelig afvistes kravet.

5.

Sag 2002-62/7-1386

En forbruger, A, der havde købt et par skatersko til sin søn, reklamerende til den erhvervsdrivende, $\mathrm{B}$, da skoenes såler på mindre end to måneder var slidt igennem. B afviste klagen, idet der efter hans opfattelse var tale om slid. A indbragte herefter sagen for Forbrugerklagenævnet. Forbrugerklagenævnet fandt, at eftersom der var tegn på, at skoene var blevet brugt forkert - det måtte blandt andet antages, at de var snøret forkert, hvilket øgede sliddet på hælen, og at A’s søn også havde anvendt skoene efter reklamationstidspunktet - måtte det konstaterede antages at skyldes ekstraordinært slid. B havde dermed afkræftet formodningen for, at der skulle foreligge fabrikations- eller materialefejl, hvilket intet tydede på. A fik derfor ikke medhold i det fremsatte krav om købets ophævelse.

6.

Sag 2002-613/7-277

En forbruger, A, havde købt en cardigan, og klagede inden for den første måned efter købet over, at tre ud af fire filtbogstaver på cardiganen var blevet beskadiget efter vask. Den erhvervsdrivende, B, mente, at beskadigelsen skyldtes, at A havde fejlbehandlet cardiganen, hvilket A afviste. Cardiganen blev i forbindelse med behandlingen i Forbrugerklagenævnet besigtiget af nævnets sagkyndige, som ikke med sikkerhed kunne fastslå. Hvad årsagen til skaderne var. Det kunne på den baggrund ikke afvises, at det konstaterede skyldtes manglende egenskaber ved varen. Forbrugerklagenævnet fandt herefter, at B ikke havde afkræftet formodningen for, at skaden skyldtes forhold, som var til stede ved leveringen, og nævnet fandt derfor, at cardiganen var væsentlig mangelfuld. A kunne derfor hæve købet.

7.

Sag 2002-4031/7-2134

En forbruger, A, købte hos en erhvervsdrivende, B, en processor og et systemkort (bundkort). A forsøgte forgæves at få delene til at fungere. A returnerede herefter delene til B. Efter en undersøgelse nægtede B imidlertid at erstatte komponenterne, idet B henviste til, at A havde beskadiget dem under monteringen. A afviste dette. Af den sagkyndige erklæring fremfik, at der var sket en nedsmeltning af 
processorens ben som følge af overclocking, som sker ved ændringer af forskellige indstillinger og placeringer i systemkortet. For så vidt angik processoren fandt nævnet, at nedsmeltningen af denne måtte have været synlig for sælgeren ved indlevering til reparation, dersom den allerede havde været beskadiget af A på dette tidspunkt. Det måtte derfor påhvile B at godtgøre, at den fysiske beskadigelse var sket før levering. Denne bevisbyrde havde B ikke løftet, hvorfor det måtte lægges til grund, at skaden først var sket efter indleveringen til undersøgelse. For så vidt angik systemkortet, fremgik det af den sagkyndige udtalelse, at det ikke kunne afvises, at dette havde været en returvare, som ikke havde levet op til standardopsætningen ved kortets levering til A. På denne baggrund og under henvisning til formodningsreglen, fandt nævnet herefter, at det måtte påhvile B at godtgøre, at ændringerne i kortet var foretaget, mens dette var i forbrugerens besiddelse. Da B ikke kunne løfte denne bevisbyrde, fik forbrugeren medhold.

8.

Sag 2003-590/7-42

Klageren havde købt en hundehvalp, som allerede dagen efter fik diarré og måtte behandles af dyrlæge. Behandlingen hjalp ikke, og klageren kontaktede derfor en ny dyrlæge, der konstaterede, at hunden led af Isospora Canis. Dyrlægen foretog derudover en operation, da det befrygtedes, at hunden havde slugt et fremmedlegeme. Klageren forlangte, at den erhvervsdrivende godtgjorde dyrlægeudgifterne, men den erhvervsdrivende ville alene godtgøre en mindre del. Forbrugerklagenævnet udtalte, blandt andet under henvisning til en udtalelse fra Det Veterinære Sundhedsråd, at det var sandsynligt, at hunden var smittet med Isospora Canis på leveringstidspunktet. Da den erhvervsdrivende herefter ikke havde afkræftet formodningen for, at sygdomsanlægget var til stede på leveringstidspunktet, lagde nævnet til grund, at hunden var behæftet med en mangel ved leveringen. Nævnet bestemte, at klageren var berettiget til at forholdsmæssigt afslag på kr. 2.000. Da den erhvervsdrivende ikke kendte eller burde have kendt til sygdomsanlægget ved leveringen, fik klageren derimod ikke godtgjort dyrlægeudgifterne.

9.

Sag 2003-521/7-162

Klageren havde købt en brugt bil til kr. 31.700. Bilen var solgt som beset. Klageren reklamerede efter kort tid over flere større og mindre fejl, herunder en defekt bagbro. For at fremskynde reparation heraf aftalte klageren med den erhvervsdrivende en ligedeling af reparationsudgifterne. Da klageren fik bilen tilbage efter 2 måneder, var der fortsat fejl, og sagen blev derfor indbragt for Forbrugerklagenævnet. Forbrugerklagenævnet udtalte, at „solgt som beset“ ikke er bindende i forbrugerkøb. Nævnet lagde, blandt andet under henvisning til en sagkyndig udtalelse, til grund, at bilen på leveringstidspunktet led af flere sikkerhedsmæssige fejl. Bilen led derfor af en mangel. For så vidt angår bagbroen udtalte nævnet, at da klageren reklamerede herover inden for 12 dage fra leveringen, og da den erhvervsdrivende ikke havde afkræftet formodningen for, at den defekte bagbro var til stede ved leveringen, havde klagerens bil også på dette punkt været mangelfuld ved leveringen. Da den erhvervsdrivende ikke havde tilbudt omkostningsfri afhjælpning havde klageren været berettiget til at lade afhjælpningen foretage af tredjemand for den erhvervsdrivendes regning. Nævnet fastsatte den samlede godtgørelse til kr. 12.700. 
Klageren havde købt et par børnestøvler til kr. 699. Knapt et halvt år efter købet gik lynlåsen i stykker. Klageren reklamerede, men den erhvervsdrivende afviste reklamationen. Forbrugerklagenævnet udtalte, at da der var reklameret inden 6 måneder efter leveringen, måtte det lægges til grund, at fejlen havde været til stedet ved leveringen. Da der var tale om en mangel, havde klageren derfor krav på et passende afslag på kr. 300. Derimod kunne klageren ikke forlange købet hævet, da manglen ikke var væsentlig.

11.

Sag 4031/7-364

Klageren havde købt en pc til kr. 8.693. 2 1⁄2 uge efter leveringen åbnede klageren kassen med pc'en og konstaterede, at fronten var knækket, og at cd-romdrevet støjede, når cd'en blev aflæst. Klageren reklamerede flere gange i ugerne derefter men blev afvist. Af den sagkyndige erklæring fremgik, at skaden mindede meget om en beskadigelse tilføjet ved et fald, slag eller stød, f.eks. under transport. Senere oplystes fra den sagkyndiges side, dels at emballagen til computeren ikke havde været beskadiget, da han modtog den til undersøgelse, dels at revnen i computeren (fronten) var vanskelig at konstatere ved en hurtig visuel inspektion. På den baggrund fandt nævnet det ikke sandsynligt, at skaden skulle være sket under hjemtransporten. Under henvisning hertil og under henvisning til formodningsreglen, fandt nævnet herefter, at det påhvilede den erhvervsdrivende at godtgøre, at revnen i fronten var sket, mens pc'en var i klagerens besiddelse, og således ikke var til stede på leveringstidspunktet. Da den erhvervsdrivende ikke havde løftet denne bevisbyrde, fandt nævnet, at der forelå en mangel, som berettigede klageren til et passende afslag på kr. 1.500 .

12.

$$
\text { Sag 590/7-44 }
$$

Klageren havde købt en hund den 2. februar 2003. Fra den 4. februar 2003 havde hunden blod i afføringen og diarré samt øremider og øjenbetændelse. Efterfølgende konstateredes flere andre fejl. Klageren kontaktede den erhvervsdrivende, som rådede klageren til at give hunden skånekost. Samtidig mente den erhvervsdrivende, at det var dumt at tage hunden med til dyrlægen for så lille en ting. Klageren henvendte sig alligevel til en dyrlæge, som behandlede hunden. Regningen lød på kr. 2.340,62, som klageren forlangte, at den erhvervsdrivende skulle godtgøre. Klageren ønskede desuden at hæve købet. Forbrugerklagenævnet udtalte, at da hunden blev undersøgt den 5. februar 2003, blev hundens almenbefindende fundet upåfaldende, og det blev udtrykkeligt præciseret, at hunden ikke blev fundet påvirket af diarré. Ifølge en sagkyndig erklæring var der på denne baggrund ikke grundlag for at antage, at fejlene havde været til stede ved leveringen. Den erhvervsdrivende havde derfor afkræftet formodningen for, at fejlene var til stede ved leveringen. Klagerens krav blev derfor afvist.

13.

Sag 521/7-366

Sagen drejede sig om køb af en 17 år gammel bil, som på købstidspunktet havde kørt 203.000 km. Prisen var 8000 kr. Ca. en måned efter leveringen, hvor bilen ifølge værkstedet skulle have kørt endnu 1259 km, opstod en fejl ved toppakningen, som måtte udskiftes. Køberen indbragte sagen for Forbrugerklagenævnet, idet han gjorde gældende, at bilen led af en mangel, og at han derfor ikke skulle 
betale reparationsudgifterne. Nævnet udtalte: „Bilen var efter det oplyste funktionsdygtig ved leveringen, og der kan under hensyn til bilens alder og kørte antal kilometer ikke opstilles en formodning for, at den senere opståede fejl ved toppakningen skyldes, at bilen ved leveringen var i en ringere stand, end klageren havde grund til at regne med, jf. herved købelovens $\S 76$, stk. 1, nr. 4 sammenholdt med $\S 77$, stk. 3 in fine.... Det findes som følge af det anførte ikke godtgjort, at det er med urette, at indklagede har afkrævet klageren betaling for reparationen...“. Forbrugeren fik herefter ikke medhold i sit krav.

13a.

Sag 4051/7-652

En forbruger købte d. 1. april 2004 en mobiltelefon. Dagen efter opdagede forbrugeren, at der var fejl i displayet, idet det blev utydeligt og forsvandt. Forbrugeren reklamerede d. 5. april, men sælgeren afviste reklamationen under henvisning til, at der var sivet væske ind i displayet. Nævnet indhentede en sagkyndig udtalelse hvoraf fremgik, at telefonen havde været udsat for væskepåvirkning i form af fugt eller kondens som følge af temperatursvingninger. Det fremgik endvidere, at der ikke var noget, der tydede på materiale- eller konstruktionsfejl. Den sagkyndiges konklusion var, at det måtte anses for „mest sandsynligt, at der foreligger en skade opstået som følge af klagerens brug af telefonen“. Forbrugerklagenævnet fandt på denne baggrund ikke at kunne træffe afgørelse i sagen uden yderligere bevisførelse, hvorfor sagen blev afvist.

\section{Norsk ret:}

14.

Sak 2004/103

Klageren, havde købt en mobiltelefon til kr. 999. Nogle måneder senere konstateredes, at vibratorfunktionen i telefonen ikke virkede efter hensigten. Telefonen blev derfor indleveret til forhandleren, som efter undersøgelse afviste reklamationen under henvisning til, at fejlen skyldtes en fugtskade. Sagen blev indbragt for Forbrukertvistutvalget, hvor forhandleren fremlagde billeder af mobiltelefonen som dokumentation for fugtskaden. Der blev herudover alene fremlagt en af forhandleren indhentet sagkyndig erklæring, hvorefter fejlene skyldtes fugtskade. Forbrukerutvalget fandt det vanskeligt at tolke billederne. Samlet fandt Forbrukertvistutvalget, at det ikke var bevist af forhandleren, at fejlen ved vibratorfunktionen ikke fandtes ved leveringen. Derfor fandtes fejlen at have været til stede ved leveringen. Klageren havde derfor ret til omlevering.

15. Sak 2004/0382

Klageren havde købt en beklædningsgenstand, som ca. en måned efter købet viste sig at have en række små huller i sømmene. Derudover var en knap faldet af med et ca. $2 \mathrm{~cm}$ stort skindstykke, et knaphul var revet af, og der var hul i en lomme. Beklædningsgenstanden blev derfor indleveret til forhandleren, som oplyste, at reparationen ville tage ca. en uge. Der gik imidlertid fire uger, før klageren kunne afhente genstanden. Reparationen var ikke tilstrækkelig godt udført, og klageren indleverede derfor atter genstanden til forhandleren. Heller ikke denne gang var reparationen i orden. Forhandleren afviste at foretage omlevering eller at give klageren ret til at hæve købet. Forbrukertvistutvalget fandt, at det fremgår af lov om forbrukerkjøp § 18, stk. 2, at hvis ikke andet bevises, anses en mangel, som viser sig inden seks måneder efter leveringen at have eksisteret på leveringstidspunktet. Derudover havde forhandleren foretaget de to afhjælpningsforsøg, som han efter 
lovens $\S 30$, stk. 2 har ret til. Han havde derfor ikke ret til at foretage yderligere afhjælpningsforsøg. Klageren kunne derfor hæve købet, da manglen var væsentlig.

16.

Sak 2003/622

Klageren havde købt en mobiltelefon for kr. 99. Nogle af telefonens taster ophørte med at fungere 4 dage efter købet. Klageren indleverede derfor telefonen til forhandleren, som oplyste, at telefonen måtte sendes til reparation. Klageren fik herefter besked om, at telefonen var fugtskadet, at det ikke var muligt at reparere den. Forbrukertvistutvalget afviste klagerens påstand om omlevering. Forhandleren havde underbygget sin påstand om fugtskade med fremlæggelse af erklæringer fra eksterne aktører, som samstemmende oplyste, at telefonen efter deres opfattelse var fugtskadet. Forbrukertvistutvalget udtalte på den baggrund: „, Utvalget har generelt inntatt det standpunkt at en mobiltelefon må kunne tåle slik fuktighet som den utsettes for ved vanlig bruk over tid ved temperatursvingninger, kondens m.v., og at det indikerer en iboende svakhet ved telefonen hvis den ikke tåler dette. I nærværende sak er sitasjonen imidlertid en annen. Utvalget viser til de samstemmige uttalelserne fra A Novo Norge A/S, Nokia og Expert Norge A7S og legger til grunn at apparartet rett og slett er blitt væskeskadet. Spørgsmålet er, om skaden er påført før eller etter levering og Utvalget finner det lite sannsynlig at den kan være påført før kjøbet. Det vises i så måte til Experts uttalelse on innpakningen, transporten til forhandleren og oppbevaringen sentrallager. Det fremstår da som mest sannsynlig at mobiltelefonen er blitt utsatt for en mindre ansamling av vann eller annen væske i den korte tiden den har vært i klagers besittelse. Han har således ikke kunnet sannsynliggjøre at det hefter noen relevant kjøpsrettslig mangel ved den, og forholdet kvalifiserer heller ikke for misligholdelsesbeføyelser af noen art. Klagen tas derfor ikke til følge“.

17.

Sag 2004/03/26

Forbrugeren købte i juni 2003 en mobiltelefon. Dagen efter købet opdagede han, a o-tasten ikke virkede ordentligt. Han reklamerede imidlertid ikke, idet han skulle på ferie. Han reklamerede derfor først i august 2003, hvor telefonen blev indleveret til forhandleren. Primo september 2003 fik han besked om, at telefonen led af en fugtskade, og at reparationen ville koste mere end NKR 3.000. Forbrugeren ønskede at hæve købet. Forbrukertvistutvalget udtalte, at det måtte lægges til grund, at svigtet skyldtes en fugtskade, men at der ikke var grundlag for at fastslå, hvorvidt skaden var opstået før eller efter risikoens overgang. Herefter citerede man formodningsreglen og udtalte, at udvalget, da man ikke kunne anse det for bevist, at skaden var opstået efter risikoens overgang, og da man heller ikke kunne anse det for uforeneligt med varens eller manglens art at antage, at der var tale om en oprindelig mangel, måtte lægge dette til grund. Manglen måtte således anses for at have foreligget ved leveringen. Forbrugeren fik derfor ret til at hæve købet, da manglen ikke var uvæsentlig.

18.

Sag 2004/02/57

Forbrugeren købte i marts 2003 en mobiltelefon. I september 2003 (inden for 6 måneders fristen) opdagede forbrugeren en fejl ved telefonen, og han reklamerede derfor til forhandleren, hvor telefonen også blev indleveret. Forhandleren videresendte telefonen til en reparatør, som fandt, at telefonen led af en fugtskade, og at det ikke kunne betale sig at udbedre skaden. Forbrugeren ønskede derfor nu at 
hæve købet. Forhandleren afgav ikke udtalelse i sagen, som derfor primært blev afgjort på baggrund af forbrugerens sagsfremstilling. Forbrukertvistutvalget udtalte, at man lagde til grund, at der var tale om en fugtskade. Man fandt endvidere ikke holdepunkter for at antage, at skaden skyldtes fejl begået af forbrugeren. Under henvisning til formodningsreglen fandt man herefter, at det måtte lægges til grund, at der var tale om en oprindelig mangel. Da afhjælpning ikke havde været aktuelt, havde forbrugeren ret til at hæve købet, idet manglen ikke var uvæsentlig.

19. Sag 2004/03/61

Forbrugeren købte en mobiltelefon i april 2003. I august 2003 indleverede han telefonen til forhandleren pga. funktionssvigt. Telefonen blev sendt til en reparatør i England, som oplyste, at telefonen havde været i vand. Forbrugeren kunne kun få telefonen tilbage, hvis hun betalte NKR 300. Forbrugeren ønskede at hæve købet. Forbrukertvistutvalget indledte med at henvise til formodningsreglen og udtalte herefter, at siden udvalget ikke kunne anse det for bevist, at forbrugeren havde påført telefonen fugtskaden, fandtes manglen at have eksisteret på leveringstidspunktet. Det tilføjedes, at det ikke fandtes bevist, at forbrugeren havde udøvet en brug af telefonen, som var udover det normale. Da afhjælpning ikke var aktuelt, og da manglen ikke var uvæsentlig, kunne forbrugeren hæve købet.

20.

Sag 2004/03/70

Forbrugeren havde købt en brugt bil i 2003. I sin klage til Forbrukertvistutvalget anførte forbrugeren, at sælgeren ca. 3 uger efter købet påsatte vinterdæk på bilen. Efter et par ture observerede forbrugeren, at bilen ikke havde et optimalt vejgreb. Forbrugeren oplyste angiveligt sælgeren herom, men denne fandt dækkene i forskriftsmæssig stand. Forbrugeren lod herefter bilens dæk undersøge af en anden forhandler, som fandt, at mønsterdybden på tre af dækkene var under de lovbefalede $3 \mathrm{~mm}$. Da forbrugeren var afhængig af sin bil, købte han nye dæk hos denne forhandler. Ifølge forbrugeren var det aftalt med bilens sælger, at denne skulle leveres med komplette vinter- og sommerdæk. Han reklamerede skriftligt ultimo januar 2004. Bilens sælger oplyste, at bilen blev leveret med vinterdæk, og at de således ikke blev eftermonteret. Forbrukertvistutvalget fandt det mest sandsynligt, at dækkene ikke var forskriftmæssige, og dermed var mangelfulde, ved leveringen, og lagde i den forbindelse afgørende vægt på, at det var begrænset, hvor meget dækkene kan være slidt i perioden fra leveringen til de blev undersøgt af den anden forhandler. Udvalget udtalte endvidere „for en ordens skyld“, at formodningsreglen ikke fandt anvendelse, idet dæk udsættes for slitage af en sådan art, at formodningsreglen i den foreliggende sag er uforenelig med manglens art. Forbrugeren havde imidlertid ikke krav på fuld erstatning, idet det kun var tre af dækkene, som ikke var forskriftmæssige, og da sælgeren ikke havde lovet ham helt nye vinterdæk.

21.

Sag 2004/03/72

Forbrugeren købte i april 2003 en mobiltelefon. Omkring to måneder efter købet kunne telefonen ikke længere oplades. Angiveligt reklamerede forbrugeren samme dag, som problemet opstod, til forhandleren, som henviste ham til en reparatør. Reparatøren undersøgte telefonen og fandt, at den havde en fugtskade. En senere undersøgelse viste, at det ikke kunne betale sig at reparere telefonen. Efter at forbrugeren havde klaget til Forbrukertvistutvalget, tilbød forhandleren at erstatte forbrugerens omkostninger forbundet med manglen, reparatørens udgifter forbun- 
det med undersøgelsen og fragt til reparatøren. Forbrugeren ville imidlertid også have en anden telefon. I klagen til Forbrukertvistutvalget krævede forbrugeren, at købet blev hævet, samt erstatning. Forbrukertvistutvalget lagde til grund, at der var tale om en fugtskade. Udvalget udtalte herefter, at det ikke var bevist, at fugtskaden var opstået, mens telefonen var i forbrugerens varetægt. Det tilføjedes: „Det er heller ikke påvist noe som tilsier at svikt skulle inntre straks fukt var kommet inn i telefonen, og at telefonen ikke kunne fungere i så lang tid som i denne saken, inntil skaden eventuelt utviklet seg dithen at svikten inntrådte“. Manglen måtte med andre ord anses for at have foreligget ved leveringen. Forbrugeren fik derfor ret til at hæve købet, da manglen ikke var uvæsentlig. Erstatningen blev skønsmæssigt fastsat.

\section{Svensk ret:}

ARN sag 2004-6150

En forbruger, A, købte i februar 2004 en brugt bil til SEK 30.000. Bilen havde ved leveringen kørt ca. 320.000 kilometer. I juni 2004 lød bilen mærkeligt, når A startede den om morgenen. A kørte derfor bilen til et autoriseret værksted (ikke sælgeren, B). Værkstedet opdagede en lang række til dels alvorlige fejl ved bilen. A reklamerede til B med krav om ophævelse samme dag. B hævede efter besigtigelse, at alle fejlene var forårsaget af A, hvorfor B afviste A's krav. A bestilte en tid hos en uafhængig ekspert (Bilprovningen) med henblik på at få foretaget en sikkerhedstest. Testen viste, at bilen var ubrugelig og farlig for trafiksikkerheden samt at samtlige fejl var oprindelige. A krævede herefter ophævelse af købet samt erstatning. Nævnet udtalte, at det var usandsynligt, at de fejl, som var angivet i klagen, var til stede ved leveringen. Der måtte være sket noget med bilen kort tid inden fejlene viste sig. A’s krav blev derfor afvist.

23.

Sag 2003-06-03; 2002-8731

Klageren havde købt en brugt bil for kr. 86.500 i begyndelsen af juli måned 2002. I oktober måned samme år brast kileremmen. Det kostede kr. 22.111 at reparere motorskaden. Klageren forlangte, at forhandleren skulle betale alle omkostninger forbundet med reparationen. Forhandleren nægtede dette og henviste til, at parterne havde aftalt, at omkostningerne ved reparationen skulle deles. Det allmänna reklamationsnämnden udtalte, at eftersom forhandleren ikke havde bevist, at fejlen, som under hensyntagen til bilens alder og stand måtte anses for en mangel, ikke var til stede ved leveringen, måtte manglen antages at have bestået ved leveringen medmindre dette var uforeneligt med varens eller manglens art. Nævnet udtalte herom: „I ärendet har säljeren inte presenteret någon utredning som visar att felet inte fanns vid avlämnandet. Felet skall därör anses ha funnits vid denne tidounkt om denna presumtion inte är oförenlig med varans eller felets art. I förarbeterna till den nya bestämmelsen i 20 a § KKL anfördes i denna fråga bl.a. att det ligger i sakens natur att de fel som kan träffas av regeln är sådana som framträder efter en tids använding, främst funktionssvikter av olika slag....Nämnden konstaterer till att börja med att det $\mathrm{i}$ ärendet inte har visats att felet är av sådan art att det beror på något förhållande på konsumentens sida...När det härefter gäller frågan om presumtionen för ursprungligt fel är oförenlig med varans art kan konstateras att ärendet gäller en begegnad bil som vid leveransen var sex år gammal och hade gått drygt 8.000 mil. En kamrem kan i någon mån sägas vara en förbruknings/förslitningsdetalj. Emellertid kan inte med säkerhet förutses - såsom i det lagens förarbeten omnämnda exemplet med färskvaror med begränsad hållbarhet 
- att en kamrem nödvändigvis kommer at gå sönder inom sex månader från leveransen. Även om der är fråga om en begegnad bil har det $\mathrm{i}$ ärendet inte kommit fram någonting som visar att antagandet att felet fanns redan vid avlämnandet skulle vara oförenligt med varans art. Säljaren kan därför inte undgå ansvar för felet på denna grund.“ Forhandleren skulle derfor tilbagebetale de kr. 10.000 til klageren, som denne var blevet afkrævet i forbindelse med reparationens udførelse, idet nævnet bemærkede, at forhandleren ikke havde ført bevis for, at der var indgået en aftale om fordeling af omkostningerne mellem parterne.

24.

Sag 2003-4989

Herefter udtalte nævnet: „Ett fel som visar sig i varan inom sex månader från det att varan avlämnades skall enligt 20 a $\S$ konsumentköplagen anses ha funnits i varan redan vid tidpunkten för avlämnandet. Säljaren skall följaktligen anses ha ansvaret för felet. För att befrias från detta ansvar måsta säljaren visa att varan var felfri när den avlämnades. Sexmånderspresumptionen bryts också om säljaren visar att presumptionen inte är förenlig med varans eller felets art. Det kan vara fallet t.ex. när varans normala livslängd är kortare än sex måneader eller om felet beror på ett olycksfall eller felaktig hantering. För att säljaren skall undgå ansvar måsta han därför i ett fall som detta visa att felet inte fanns vid avlämnandet eller att presumptionen är oförenlig med varans eller felets art. .....Säljaren har på sin sida inte presenteret någon utredning som visar att felet inte fanns vid avlämnandet. Säljaren har inte heller visat att presumptionen om fel vid avlämnandet är oförenlig med varans eller felets art“. Nævnet fremhævede i den forbindelse, at den beskrivelse af bilen, som B havde påberåbt sig til støtte for sin afvisning af A’s krav, ikke viste andet end at bilens gearkasse var i normal stand. En sådan beskrivelse af bilen kan indgå i vurderingen af, hvorvidt bilen var mangelfuld ved leveringen, men er den udarbejdet - og er den bagvedliggende undersøgelse af bilen foretaget - af sælgeren, kan den ikke tillægges selvstændig bevisværdi for så vidt angår spørgsmålet om, hvorvidt bilen var mangelfri ved leveringen. På den baggrund fandt nævnet, at B skulle erstatte A’s omkostninger. Afgørelsen var ikke enstemmig.

25.

Sag 2003-5348

En forbruger, A, købte i januar 2003 en brugt bil til SEK 50.000. Bilen havde ved leveringen kørt 230.000 kilometer. I maj 2003 begyndte kølervandet at løbe direkte igennem køleren. Bilen blev kørt til B, som tilbød at afhjælpe problemet for A's egen regning. Dette ville A ikke acceptere. Efter yderligere kontakt mellem parterne, som ikke førte til en afklaring, blev køleren repareret hos en autoriseret kølermontør i juni 2003. Prisen herfor var SEK 5.399. Reparatøren angav i fakturaen, at køleren havde været i stykker længe. A forlangte herefter sine omkostninger erstattet af B. B nægtede dette. I den aktuelle sag udtalte nævnet, at det forhold, at en køler går i stykker på en bil, som er otte år gammel og har kørt 230.000 kilometer, ikke er noget, som normalt indtræffer. Der var derfor ikke tale om almindelig slitage, og A havde derfor ikke haft anledning til at regne med fejlen så kort tid efter leveringen. Bilen afveg derfor fra, hvad A med rette havde forventet, og var følgelig mangelfuld. Herefter udtalte nævnet: „Ett fel som visar sig i varan inom sex månader från det att varan avlämnades skall enligt 20 a § konsumentköplagen anses ha funnits i varan redan vid tidpunkten för avlämnandet. Säljaren skall följaktligen anses ha ansvaret för felet. För att befrias från detta ansvar måsta säljaren visa att varan var felfri när den avlämnades. Sexmånderspresumptionen bryts också om säljaren visar att presumptionen inte är förenlig med varans eller felets 
art. Det kan vara fallet t.ex. när varans normala livslängd är kortare än sex måneader eller om felet beror på ett olycksfall eller felaktig hantering. För att säljaren skall undgå ansvar måsta han därför i ett fall som detta visa att felet inte fanns vid avlämnandet eller att presumptionen är oförenlig med varans eller felets art. .....Säljaren har på sin sida inte presenteret någon utredning som visar att felet inte fanns vid avlämnandet. Säljaren har inte heller visat att presumptionen om fel vid avlämnandet är oförenlig med varans eller felets art“. Nævnet henviste i den forbindelse til, at det fremgik af fakturaen fra kølermontøren, at køleren havde været i stykker længe. Der var derudover indleveret fotos, som bestyrkede kølermontørens oplysning. På den baggrund fandt nævnet, at B skulle erstatte A’s omkostninger til reparationen samt benzinomkostninger. Afgørelsen var ikke enstemmig.

26.

Sag 2004-03-03; 2003-4991

Klageren havde købt en brugt bil for kr. 108.000. Da klageren kørte bilen hjem efter købsaftalens indgåelse konstaterede han, at der forekom spændingsfald i bilens elektroniske installationer. Al belysning inde i bilen og bilens lygter blinkede. I tiden efter købet kunne han endvidere høre en hvinende lyd i motoren, som tog til i styrke, hvorefter drivremmen til generatoren og vandpumpen brast. Bilen blev indleveret på værksted, som konstaterede, at to ud af tre tandhjul, som holdt remmen på plads, ikke fungerede efter hensigten. Dette havde ført til, at drivremmen var blevet overophedet og sluttelig var bristet. Værkstedet oplyste, at et af tandhjulene havde været i stykker i længere tid. Efter at have fået bilen retur fra værkstedet opdagede klageren forskellige andre fejl ved bilen. Han kontaktede derfor forhandleren, som imidlertid ikke ville betale for udbedring. Han henviste til, at han var fri for ansvar, som blev opdaget efter leveringen, idet der var foretaget en test af bilen hos Svensk Bilprovning, hvor fejlen ikke blev fundet. Nævnet lagde til grund, at der forelå en køberetlig mangel ved bilen. Nævnet udtalte herefter: „Ett fel som visar sig i varan inom sex månader från det att varan avlämnades skall enligt 20 a § konsumentköplagen anses ha funnits i varan redan vid tidpunkten för avlämnandet. Säljaren skall följaktligen anses ha ansvaret för felet. För att befrias från detta ansvar måsta säljaren visa att varan var felfri när den avlämnades. Sexmånderspresumptionen bryts också om säljaren visar att presumptionen inte är förenlig med varans eller felets art. Det kan vara fallet t.ex. när varans normala livslängd är kortare än sex måneder eller om felet beror på ett olycksfall eller felaktig hantering. För att säljaren skall undgå ansvar måsta han därför i ett fall som detta visa att felet inte fanns vid avlämnandet eller att presumptionen är oförenlig med varans eller felets art“. Nævnet fandt, at eftersom forhandleren gennem fremlæggelse af testen fra Svensk Bilprovning havde bevist, at fejlene ikke var til stede ved leveringen, kunne nævnet ikke give klageren medhold i, at forhandleren skulle betale for reparationen eller for bjærgningsomkostningerne.

27.

Sag 2004-03-03; 2003-4343

Klageren købte i februar 2003 en brugt bil til kr. 25.000. Forhandleren oplyste i markedsføringen af bilen, at denne havde fået renoveret topstykket. Da klageren kørte hjem i bilen opdagede han, at førersædet var nedslidt, og at ryglænet ikke kunne reguleres. El-spejlene kunne heller ikke reguleres, ligesom der viste sig forskellige andre fejl. Fem dage efter købet gik bilen i stå og måtte transporteres på værksted. Den nødvendige reparation beløb sig til kr. 8.069. Forhandleren leverede nogle andre brugte frontsæder og el-spejle, mens klageren selv betalte for monteringen heraf. Klageren krævede nu det fulde beløb erstattet. Forhandleren næg- 
tede dette under henvisning til, at bilen blev leveret nysynet uden anmærkninger. Klageren var blevet informeret om stolenes tilstand. I det hele taget anførte forhandleren, at bilen ikke havde nogen fejl ved leveringen. Det allmänna reklamationsnämnden udtalte, at når der foretages en renovering af en bils topstykke er det ikke i overensstemmelse med god skik i branchen, hvis drivremmen ikke udskiftes samtidig. Trods bilens alder og almene stand led bilen derfor af en mangel. Herefter udtalte nævnet: „Ett fel som visar sig i varan inom sex månader från det att varan avlämnades skall enligt 20 a $\S$ konsumentköplagen anses ha funnits i varan redan vid tidpunkten för avlämnandet. Säljaren skall följaktligen anses ha ansvaret för felet. För att befrias från detta ansvar måsta säljaren visa att varan var felfri när den avlämnades. Sexmånderspresumptionen bryts också om säljaren visar att presumptionen inte är förenlig med varans eller felets art. Det kan vara fallet t.ex. när varans normala livslängd är kortare än sex måneader eller om felet beror på ett olycksfall eller felaktig hantering. För att säljaren skall undgå ansvar måsta han därför i ett fall som detta visa att felet inte fanns vid avlämnandet eller att presumptionen är oförenlig med varans eller felets art. .....Säljaren har på sin sida inte presenteret någon utredning som visar att felet inte fanns vid avlämnandet. Säljaren har inte heller visat att presumptionen om fel vid avlämnandet är oförenlig med varans eller felets art“. Da drivremmen brast fem dage efter leveringen, og eftersom forhandleren ikke havde bevist, at drivremmen var fejlfri ved leveringen, eller at formodningen for, at manglen var til stede ved leveringen, var uforenelig med fejlens eller salgsgenstandens art, skulle forhandleren erstatte klageren de reparationsomkostninger, denne havde haft som følge af, at drivremmen brast. Derimod afviste nævnet klagerens øvrige påstande, herunder om, at forhandleren skulle betale for monteringen af sæderne og el-spejlene, da der her var tale om fejl, som klageren burde have opdaget før købet

28.

Sag 2003-06-05; 2003-0397

Klageren havde købt en beklædningsgenstand for kr. 799. Anden gang, hun anvendte genstanden, opdagede hun, at den havde pletter. Hun antog, at pletterne stammede fra maskinolie, og at de havde været til stede ved leveringen, men at hun ikke havde set dem da på grund af den kunstige belysning i forretningen. Hun ønskede nu at hæve købet. Forhandleren nægtede at efterkomme dette krav og anførte, at klageren selv havde påført pletterne. Det allmänna reklamationsnämnden udtalte, at eftersom forhandleren ikke havde bevist, at pletterne, som måtte anses for en væsentlig mangel, ikke var til stede ved leveringen, måtte manglen antages at have bestået ved leveringen. Klageren havde derfor ret til at hæve købet.

29.

Sag 2004-04-06; 2004-0068

Klageren havde købt et par støvler til kr. 1.350. Hælen faldt af efter almindelig brug. Klageren reklamerede derfor til forhandleren med krav om ophævelse af købet, hvilket forhandleren afviste. Det allmänna reklamationsnämnden udtalte, at eftersom forhandleren ikke havde bevist, at fejlen, som måtte anses for en væsentlig mangel, der ikke kunne udbedres, ikke var til stede ved leveringen, måtte manglen antages at have bestået ved leveringen. Klageren havde derfor ret til at hæve købet.

Klageren købte en kat den 1. februar 2003. Den 14. juli tog hun katten med til dyrlægen, og to dage senere blev katten aflivet. Klageren ønskede at få købesum- 
men tilbage og at få dækket omkostningerne til aflivning af katten. Sælgeren nægtede dette under henvisning til, at klageren ikke havde fremlagt hverken udtalelse fra dyrlægen eller obduktionsrapport. Det allmänna reklamationsnämnden fandt, at sælgeren var erhvervsdrivende og dermed omfattet af konsumentköplagen. Nævnet konstaterede herefter, at katten ved købsaftalens indgåelse var ledsaget af en af en dyrlæge udfærdiget helbredserklæring. Da klageren ikke, trods opfordret hertil, havde fremlagt hverken en udtalelse fra den dyrlæge, som foretog aflivningen, eller en obduktionsrapport, havde klageren ikke bevist, at katten, da den blev aflivet, havde en sådan sygdom eller lignende, at den måtte anses for mangelfuld i lovens betydning. Nævnet afviste derfor klagerens krav.

\section{Finsk ret:}

31.

Sag $02 / 31 / 1617$

En forbruger købte den 4.1.2002 et par vintersko til sin datter. Efter en måned gik en af skoenes låse i stykker, hvilket den erhvervsdrivende reparerede vederlagsfrit. Et par måneder efter købet sprak skoenes overlæder. Den erhvervsdrivende sendte skoene til en skomager, som konstaterede, at skoene havde været udsat for en hård brug, og at de ikke længere kunne repareres. Forbrugeren krævede herefter enten et par nye sko eller en ophævelse af købet. Konsumentklagonämnden undersøgte skoene og fandt, at skoenes ydermateriale ikke var egnet til vinterbrug. Nævnet udtalte herefter, at eftersom skomaterialet var behæftet med fejl, anså nævnet det for klargjort, at der forelå en mangel, som den erhvervsdrivende var ansvarlig for, og at manglen forelå allerede ved leveringen. Da manglen ikke kunne afhjælpes, og da omlevering ikke var mulig, havde forbrugeren ret til at hæve købet.

32.

Sag $02 / 31 / 2285$

En forbruger købte den 30.4.2002 et par støvler. I henhold til varedeklarationen bestod støvlernes såler mv. af læder. Forbrugeren anvendte støvlerne en enkelt gang udendørs på et tidspunkt, hvor gaden var delvis fugtig. Efter en halv times brug var støvlerne meget nedslidte. Forbrugeren henvendte sig derefter til den erhvervsdrivende, som afviste klagen med den begrundelse, at der måtte være tale om en brugsfejl. Forbrugeren krævede, at købet skulle ophæves, og at hun fik erstattet rejseomkostninger. Konsumentklagonämnden undersøgte støvlerne og fandt, at de var forsynet med så tynde såler, at de alene var egnede til indendørs brug. Da forbrugeren ikke var informeret herom ved købet, forelå der en mangel. Nævnet fandt herefter, at den erhvervsdrivende skulle afhjælpe manglen ved at påsætte nye såler mv.

33.

En forbruger købte den 23.1.2002 en barneoverall. Allerede på andendagen efter købet var der en flænge i overallens ene bukseben. Forbrugeren krævede erstatning af den erhvervsdrivende under henvisning til, at børnetøj bør kunne tåle udendørs leg også på knæ. Konsumentklagonämnden fandt, at overallen var af normal kvalitet, og det faktum at overallen havde fået en flænge var ikke bevis for, at varen led af en mangel. Forbrugerens krav blev derfor ikke imødekommet. 
En forbruger købte i juni 2002 nogle roser af en erhvervsdrivende. Efter ca. tre uger blev roserne angrebet af meldug, som spredte sig til forbrugerens øvrige planter. Forbrugeren krævede herefter sine penge tilbage samt erstatning til indkøb af ny jord mv. Konsumentklagonämnden fandt, at meldug var en almindelig sygdom, som spredes med vinden. Under hensyntagen til at symptomerne først havde vist sig tre uger efter købet, fandt nævnet, at sælgeren havde bevist, at planterne ikke på leveringstidspunktet havde været bærere af sygdommen i latent form, hvorfor forbrugerens krav ikke kunne imødekommes.

En forbruger købte den 2.5.2002 en hundehvalp. Hvalpen døde den 6.5.2002. Ifølge en sagkyndig erklæring døde hvalpen som følge af en infektion, forårsaget af en særlig sygdom. Forbrugeren krævede at få sine penge tilbage, hvilket den erhvervsdrivende afviste. Konsumentklagonämnden konstaterede, at hvalpens sygdom var en mangel. Ifølge en sagkyndig erklæring måtte det lægges til grund, at manglen havde været til stede på leveringstidspunktet. Under henvisning til denne erklæring samt til formodningsreglen, fandt nævnet også, at manglen havde været til stede ved leveringen. Da den erhvervsdrivende ikke kunne modbevise dette, havde forbrugeren ret til at hæve købet.

36. Sag 03/33/2654

En forbruger købte i april 2003 en brugt bil af en erhvervsdrivende bilsælger. Forbrugeren klagede kort tid efter købet over, at fjernbetjeningen til bilens centrallåsesystem havde en meget svag sendeeffekt. Fejlen kunne ikke afhjælpes på anden vis, end ved at udskifte enheden, hvilket ville koste 104 EUR inkl. omkodning. Forbrugeren krævede, at bilsælgeren skulle betale, idet der var klaget inden 6 måneder efter leveringen. Nævnet udtalte, at det følger af 5 kap. $15 \S$ i konsumentskyddslagen, at tidspunktet for mangelsbedømmelsen er det tidspunkt, hvor risikoen overgik til forbrugeren, men at formodningsreglen gør det klart, at en mangel anses for at have foreligget ved leveringen (risikoens overgang), medmindre andet bevises eller det er uforeneligt med manglens karakter at antage, at den var til stede ved leveringen. Det centrale var herefter, hvorvidt fejlen indebar, at bilen led af en mangel. Det blev herefter lagt til grund, at det er forbrugeren, som skal bevise, at der er tale om en fejl. Forbrugeren skal derimod ikke bevise, at en sådan eventuel fejl var til stede ved leveringen. Nævnet afgjorde, at fejlen i fjernbetjeningen ikke udgjorde en mangel, og forbrugerens krav blev derfor ikke imødekommet.

37.

Sag 03/33/223

En forbruger købte i juli 2002 en brugt bil af en erhvervsdrivende bilsælger. I december 2002 opdagede forbrugeren en fejl i bilens motorvarmer. Forbrugeren reklamerede overfor bilsælgeren i januar 2003. Bilsælgeren forsøgte forgæves afhjælpning. Omkostningerne til afhjælpningen beløb sig til 102 EUR. Forbrugeren kontaktede herefter den person, som havde foretaget det første forsøg på afhjælpning, og fik oplyst, at hele motorvarmeren skulle udskiftes, hvilket ville beløbe sig til 600 EUR. Forbrugeren krævede herefter, at bilsælgeren skulle betale afhjælpningsomkostningerne samt omkostningerne til en udskiftning af motorvarmeren. 
Under henvisning til 5 kap. 14 §g 5 kap. 15 § i konsumentskyddslagen udtalte nævnet, at bilen ikke, på et tidspunkt, hvor forbrugeren havde kørt ca. 30.000 kilometer i bilen siden leveringen, var i en dårligere stand ved leveringen, end forbrugeren med rette kunne have forventet. Forbrugeren havde med andre ord ikke bevist, at bilen var led af en mangel.

38.

$$
\text { Sag 04/36/565 }
$$

En forbruger købte i november 2003 tre akvariefisk. Kort efter at fiskene var udsat i forbrugerens akvarium, udviste de sygdomstegn. Fiskene blev herefter behandlet mod parasitter mv. En af fiskene blev sendt til undersøgelse hos en ekspert, der senere samme måned konstaterede, at fisken led af fisketuberkulose. Spørgsmålet var herefter, om det var de tre akvariefisk, som havde indført smitten i forbrugerens akvarium, og om sælgeren, hvis dette var tilfældet, var erstatningsansvarlig herfor. Forbrugeren krævede erstatning for de sygdomsramte fisk, planter og akvariesandet til en samlet værdi af 610,50 EUR. Sælgeren havde tilbagebetalt vederlaget for fiskene til forbrugeren og erstattet forbrugerens omkostninger til ekspertundersøgelsen og bestred i øvrigt opgørelsen af forbrugerens erstatningskrav. Under henvisning til 5 kap. 12 § og 5 kap. 15 § i konsumentskyddslagen udtalte nævnet, at en smitsom sygdom hos en solgt fisk kan udgøre en mangel, idet man dog måtte tage hensyn til, at der var tale om levende dyr. Et særligt problem var det, om de solgte fisk led af en mangel (=led af fisketuberkulose) allerede ved leveringen. Nævnet udtalte endvidere, at fiskesygdomme ofte rammer nyudsatte fisk i akvarier, fordi fiskene endnu ikke har udviklet resistens mod eksisterende bakterier i akvariet. Også stress i forbindelse med flytningen kan påvirke fiskene. Af en ekspertudtalelse fremgik, at så godt som hvert eneste akvarium indeholder fisk med smittebærere. Nævnet udtalte på denne baggrund: „Såsom ovan har konstaterats, antas ett fel i en vara ha förekommit redan vid tidspunkten för köpet, om felet visar sig inom sex månader från köpet och motsatsen inte bevisas. Det faktum att den säljande affärens övriga fiskar enligt säljarens utsago inte drabbats av tuberkulos tyder på att sjukdomen funnits latent i köparens akvarium. Med beaktande av den utredning som förts fram i ärendet och de typiska sätten för överföring av fisksjukdomar i akvarier med flera fiskarter, anser nämnden att det $\mathrm{i}$ föreliggeande fall visats med tillräcklig sannolikhet att sjukdomen inte fans hos fiskarna vid riskens övergang, altså vid köpet“. Forbrugeren fik herefter ikke medhold i sit krav.

\section{Sag $04 / 36 / 735$}

En forbruger købte i januar 2004 tre akvariefisk. Kort tid efter købet underrettede forbrugeren sælgeren om, at sygdommen hvid prikkesyge nu fandtes i hans akvarium. Forbrugeren påstod, at sygdommens tilstedeværelse var forårsaget af de indkøbte fisk, hvorfor han krævede erstatning for fiskedød mv. for i alt 141,50 EUR. Sælgeren afviste dette. Nævnet udtalte, under henvisning til 5 kap. $12 \S$ og 5 kap. $15 \S$ i konsumentskyddslagen, og idet man citerede formodningsreglen, at en smitsom sygdom hos en solgt fisk kan udgøre en mangel, idet man dog måtte tage hensyn til, at der var tale om levende dyr. Nævnet fandt, at fiskene, henset til hvor hurtigt efter leveringen sygdommen viste sig, led af en mangel på leveringstidspunktet. Da sælgeren ikke havde afhjulpet eller foretaget omlevering, havde forbrugeren, idet der var tale om en væsentlig mangel, ret til at hæve købet og kræve erstatning. Erstatningen blev fastsat til 20 EUR, idet nævnet bemærkede, at forbrugeren til en vis grad havde udvist egen skyld, idet akvariet, allerede inden de indkøbte fisk blev sat ud, var overfyldt, havde dårlig vandkvalitet mv. 
_En forbruger, A, købte den 10. januar 2002 en brugt snescooter for EUR 1680. Snescooteren var taget i brug i 1994, og kilometertælleren viste 11.162 kilometer på købstidspunktet. Sælgeren, B, havde oplyst A om den mængde olie, som skulle blandes i brændstoffet, og havde endvidere påsat en mærkat på frontpanelet til erindring herom. Snescooterens motor gik i stykker i april 2002. Reparationsomkostningerne blev opgjort til EUR 840. A krævede omkostningerne til reparationen betalt af $\mathrm{B}$. Konsumentklagonämnden fik foretaget en undersøgelse af snescooteren fra den virksomhed, som havde foretaget reparationen. Ifølge undersøgelsen var snescooterens cylindere brændt sammen, og scooteren var desuden boret for at opnå større volumen. Blandt andet under hensyntagen til snescooterens alder og generelle stand fandt nævnet ikke, at den havde været mangelfuld på købstidspunktet, jf. 5 kapitel 14 §, 3. punkt i konsumentskyddslagen. A’s krav blev derfor ikke taget til følge. Nævnet udtalte, at eftersom en snescooter er udsat for slitage i forbindelse med brugen og tiden, bør forbrugeren være forberedt på, at det, måske endog inden for kort tid efter købet, kan blive nødvendigt at udføre påkrævede reparationer på brugte snescootere.

41.

Reparation af en cykelfælg (ikke nummereret)

En forbruger, A, købte i april 2003 en cykelfælg til baghjulet på en cykel for EUR 50. To måneder efter købet begyndte fælgens eger pludselig at gå af, hvorfor A henvendte sig til sælgeren, B, med krav om afhjælpning. B konstaterede, at der var en fejl i fælgens nav, og lovede at fremsende fælgen til sin leverandør med henblik på reparation inden for garantiperioden. Da A kom for at hente fælgen oplyste B imidlertid, at afhjælpningen kostede EUR 30, da der ikke var nogen garanti på cykeldele. A krævede herefter at få tilbagebetalt de EUR 30, han havde betalt, og at der skulle gives gratis service på fælgen i 6 måneder. Konsumentklagonämnden citerede formodningsreglen og konstaterede, at fælgen var gået i stykker efter to måneders brug. Da B ikke havde oplyst, hvad manglen på fælgen var forårsaget af, og således ikke havde dokumenteret, at manglen var forårsaget af $\mathrm{A}$, afgjorde nævnet, at B skulle tilbagebetale de EUR 30 til A, som han havde betalt for afhjælpningen.

42. $\quad$ Køb af trøje (ikke nummereret)

En forbruger, A, købte den 5. februar 2002 en trøje for EUR 36. Inden A begyndte at bruge trøjen, vaskede hun den. Efter vasken opdagede A, at der fandtes pletter på trøjen. A krævede herefter købet ophævet. Sælgeren, B, henviste til importørens forklaring, hvorefter trøjen skulle vaskes under iagttagelse af en række særlige foranstaltninger, hvilket A ikke havde overholdt. Konsumentklagonämnden foretog en undersøgelse af trøjen, og fandt ikke, at den led af en mangel. Pletterne var opstået i forbindelse med vasken, som B ikke var ansvarlig for. A fik derfor ikke medhold i sit krav om ophævelse, og nævnet fandt heller ikke anledning til at tillade A at anvende andre beføjelser. Det fremgår ikke af referatet, om A var blevet oplyst om de særlige foranstaltninger, som skulle iagttages i forbindelse med vasken, herunder om trøjen var påsat vaskeanvisninger mv.

43.

Køb af jakke (ikke nummereret)

En forbruger, A, købte den 14. maj 2003 en jakke for EUR 69. Da A havde brugt jakken en enkelt gang i nogle timer, vaskede hun den ved brug af et skånsomt va- 
skemiddel. Efter vasken opdagede A en række huller i det ene jakkeærme. Efter A's opfattelse beroede hullerne på en mangelfuld forarbejdning, hvilket sælgeren, B, nægtede. A krævede herefter, at B skulle ombytte jakken eller alternativt, at købet blev ophævet og omkostningerne forbundet med miseren skulle erstattes. B afviste A's krav. Konsumentklagonämnden foretog en undersøgelse af jakken og fandt ikke, at der var tale om en forarbejdningsmangel. Hvis hullerne havde været til stede allerede på leveringsstidspunktet, ville disse have været synlige for køberen på dette tidspunkt. Nævnet fandt herefter, at da hullerne først var opstået efter risikoens overgang og altså ikke var forårsaget af en mangel ved jakken, var jakken ikke mangelfuld. A’s krav blev derfor afvist.

44. Køb af jakke og bukser (ikke nummereret)

En forbruger, A, købte den 13. april 2002 et par bukser for EUR 99. Han købte ved samme lejlighed en tilhørende jakke til EUR 134. Om eftermiddagen den første dag, da A havde anvendt sættet, lagde hun mærke til, at stoffet omkring knæene på buksernes yderside var begyndt at flosse. A klippede de løse tråde af for, at bukserne skulle se pænere ud. Det hjalp øjensynligt ikke. Sælgeren, B, ville ikke foretage sig noget, da bukserne efter hans opfattelse ikke led af en mangel. A krævede herefter, at bukserne skulle ombyttes eller alternativt, at købet skulle ophæves. B påstod, at der var tale om en skade, som var forårsaget af ydre påvirkning, og ikke som følge af en mangel ved bukserne. Konsumentklagonämnden undersøgte bukserne og fandt ikke, at bukserne led af en mangel. På højre bukseben var et større „afskallet“ område. Skaden måtte anses forårsaget af en exceptionel brug (A oplyste, at hun blandt andet havde placeret en bærbar pc på skødet; bukserne var fremstillet af et sart materiale), og A’s krav blev derfor afvist.

45.

Køb af brugt personbil (ikke nummereret)

En forbruger købte en 7 år gammel personbil, der havde kørt $173.000 \mathrm{~km}$. for 11.600 euro. 2 måneder efter leveringen gik bilens katalysator i stykker. Forbrugeren krævede, at sælgeren dækkede udgifterne til en ny katalysator. Sælgeren afviste dette under henvisning til, at skaden måtte antages at skyldes køberens uhensigtsmæssige brug. Der forelå en udtalelse fra det værksted, som køberen havde fået til at reparere bilen. Det fremgik heraf, at bilens katalysator var smeltet, og dette ikke ville ske medmindre der havde været fejl i anordningen for brændselstilførsel. Nævnet anførte, at det måtte anses for sandsynligt, at de fejlagtige indstillinger af motoren, som værkstedet havde påpeget, havde bidraget til skaden, og at sælgeren ikke havde bevist, at de fejlagtige indstillinger skulle være forårsaget af køberen. På dette grundlag og under henvisning til formodningsregel, lagde nævnet herefter til grund, at der havde været tale om en oprindelig mangel, hvorfor sælgeren var ansvarlig.

\section{Reklamationsfrister}

\section{Dansk ret:}

46.

Sag 4031/7-1053

En forbruger, A, købte i september 2002 en pc. Ca. 15 måneder efter købet konstaterede A, at pc'en begyndte at fryse for efterfølgende at fremstå med sort 
skærm. A reklamerede til sælgeren, B, som afviste reklamationen med henvisning til, at bundkortet måtte være gået i stykker som følge af „elektriske udladninger ved tilslutning af andre ydre enheder, udladninger fra lyn eller utilstrækkelig ventilation“ A indbragte sagen for Forbrugerklagenævnet med krav om afhjælpning, omlevering eller ophævelse. B afviste dette. Det var ikke muligt at skille bundkortet ad og foretage en sagkyndig vurdering af dette, men nævnets faste edbsagkyndige udtalte, at det ikke var sandsynligt, at defekten skyldtes egenskaber ved pc'en, som havde været til stede ved leveringen, men i stedet måtte antages at skyldes for eksempel udladninger fra lyn eller utilstrækkelig ventilation. På den baggrund fandt Forbrugerklagenævnet ikke, at det var godtgjort, at der var tale om en oprindelig mangel. A fik derfor ikke medhold i sine krav.

47.

Sag 4031/7-1024

En forbruger, A, købte i april 2002 en pc. Efter 22 måneder ville den kun starte op, men ikke vise noget skærmbillede. A reklamerede derfor til sælgeren, B, som efter undersøgelse af pc'en oplyste A om, at bundkortet skulle udskiftes. B afviste A's reklamation med den begrundelse, at der var tale om slitage og ikke en mangel. A indbragte sagen for Forbrugerklagenævnet med krav om ophævelse af købet. I den af forbrugerklagenævnet indhentede sagkyndige erklæring udtaltes, at der ikke var korrekt spænding i systemkortet, og at der ikke var tegn på uhensigtsmæssig brugspåvirkning fra forbrugerens side, hvorfor den sagkyndige anså det for „overvejende sandsynligt, at computeren er behæftet med en oprindelig mangel“. Forbrugerklagenævnet udtalte, at et bundkort skal kunne holde til almindelig brugspåvirkning i mere end to år. Det fandtes derfor - under henvisning til den sagkyndiges erklæring - overvejende sandsynligt, at pc’en var behæftet med en oprindelig mangel. Da B ikke havde foretaget afhjælpning inden rimelig tid, havde A ret til at ophæve købet.

48.

Sag 4051/7-551

En forbruger, A, købte i februar 2002 en trådløs telefon. Ca. 23 måneder efter henvendte A sig til sælgeren, $\mathrm{B}$, og klagede over, at håndsættet ikke kunne lade, og at der ikke var forbindelse til basen. B solgte et nyt sæt batterier til A, men dette hjalp ikke. B tilbød herefter at sende telefonen videre til undersøgelse, men A indbragte sagen for Forbrugerklagenævnet med påstand om ophævelse, da der ikke var sket afhjælpning inden rimelig tid. B afviste dette og henviste til, at den manglende funktion skyldtes, at A havde „sjat-ladet“ batterierne. Ifølge den af nævnet indhentede sagkyndige erklæring skyldtes problemet enten, at batterierne var defekte, eller at disse var blevet ødelagt ved „sjat-ladning“. Den sagkyndige oplyste endvidere, at batterier af den pågældende type typisk kan holde til 1000 opladninger svarende til én opladning i døgnet i 2,7 år. Da der således var tale om batterier, hvis levetid afhang af anvendelsesforholdene, og da de pågældende batterier havde holdt i 23 måneder, fandt nævnet det ikke godtgjort, at disse havde været mangelfulde ved leveringen. Da der heller ikke i øvrigt var påvist mangler ved telefonen, fik forbrugeren ikke med hold i sit krav.

49.

Sag 4012/7-321

En forbruger, A, købte i december 2002 et tv. I tre tilfælde, henholdsvis to gange i juli 2003 og én gang i august 2003, reklamerede A over dels en hylelyd, dels fejl i billedrøret, som gav sig udslag i røde og grønne striber over skærmen. B påstod, at A selv havde forårsaget fejlene ved at have tabt tv'et. A indbragte sagen for 
Forbrugerklagenævnet med krav om ophævelse, afhjælpning eller omlevering og afviste selv at have forårsaget fejlene. Forbrugerklagenævnet lagde på baggrund af den af nævnet indhentede sagkyndige erklæring til grund, at hyletonen skyldtes en oprindelig mangel ved tv'et. For så vidt angik billedrøret havde den sagkyndige udtalt, at dette ikke var en ofte forekommende fabrikationsfejl, og at det i den konkrete sag ikke var muligt at sige, hvornår fejlen var opstået. Samtidig vurderedes, at det ikke kunne udelukkes, at fejlen var opstået ved, at tv'et var blevet udsat for stød, men at der i så fald sædvanligvis også ville være ske skade på kabinettet (hvilket ikke var tilfældet). Et flertal i nævnet fandt på denne baggrund, at forbrugeren havde bevist, at fejlene beroede på fabrikations- og/eller materialefejl, som havde været til stede ved leveringen. Mindretallet fandt, at da den sagkyndige ikke med sikkerhed havde været i stand til at fastslå, om fejlen havde været til stede ved leveringen, havde A ikke løftet sin bevisbyrde. Der blev truffet afgørelse efter flertallets opfattelse, således at A havde ret til at hæve købet, idet fejlene alt i alt måtte anses for en væsentlig mangel.

50.

Sag 4031/7-758

En forbruger, A, købte i januar 2002 en multifunktionsmaskine (printer, kopi og scanner). I maj 2003 henvendte A sig til sælgeren, B, for at reklamere over scannerfejl og manglende kopieringsevne. B bad A om at ringe til producenten, C, for at få telefonisk assistance til at klare fejlene. Dette hjalp imidlertid ikke, og A henvendte sig derfor atter til B. I de følgende måneder foretog B en række afhjælpningsforsøg, som kun delvist afhjalp problemerne. I september 2003 henvendte A sig atter til B, men B oplyste nu, at produktet ikke længere var dækket af garanti, og at reklamationsretten ikke dækkede fejlene, da de først var opstået mere end 6 måneder efter købet. $\mathrm{B}$ tilbød i stedet $\mathrm{A}$ ombytning med en brugt printer mod betaling af kr. 1.000, hvilket A afslog. A indbragte sagen for Forbrugerklagenævnet med krav om ophævelse. B afviste dette, da det ikke var bevist, at fejlene var til stede ved leveringen. I den af forbrugerklagenævnet indhentede sagkyndige erklæring udtaltes: „Det kan ikke klarlægges med sikkerhed, hvorvidt fejlen kan henføres til forhold fra klagers side eller skyldes de under spørgsmål 2a anførte forhold [materiale- eller fabrikationsfejl]. Det skønnes dog mest sandsynligt, at fejlen kan henføres til et af de under spørgsmål 2a anførte forhold, idet der ikke ved undersøgelse af produktet har kunnet konstateres synlige fysiske beskadigelser, samt at der ikke ved kontakten med producentens hotline har kunnet klarlægges på hvilken måde klageren ved almindelig brug (i modsætning til intensiv brug) skulle kunne tilføre produktet en beskadigelse som den foreliggende“. Forbrugerklagenævnet fandt på den baggrund, at det var mest sandsynligt, at fejlene kunne henføres til fabrikations- og/eller materialefejl. Der var derfor tale om en oprindelig fejl, hvorfor maskinen led af en mangel, og da den ikke var afhjulpet inden rimelig tid, havde A ret til at hæve købet.

En forbruger havde i december 2002 købt et par støvler. Hælen knækkede d. 2. maj 2003, og forbrugeren reklamerede i slutningen af august 2003. Der var afgivet to modstridende sagkyndige erklæringer, idet den ene konkluderede, at der ikke var tegn på uhensigtsmæssig brug, og at det var overvejende sandsynligt, at der var tale om en fabrikationsfejl, idet der var konstateret en urenhed i materialet, mens den anden konkluderede, at urenheden i materialet var uden betydning, idet styrken lå i røret, der løb midt i hælen, hvorfor skaden med overvejende sandsynlighed måtte antages at skyldes uhensigtsmæssig brugspåvirkning. Forbrugerkla- 
genævnet fandt under henvisning til den anden erklæring samt under henvisning til, at der kunne konstateres en ridse i hælen, og at høje hæle generelt er sårbare over for ydre påvirkninger, at det var mest sandsynligt, at der var tale om en skade, der var opstået under uhensigtsmæssig brugspåvirkning. Forbrugeren fik derfor ikke medhold i sit krav.

$50 \mathrm{~b}$

Sag 4031/7-878

Forbrugeren købte i maj 2002 en computer og efter ca. 15 måneder reklamerede forbrugeren over, at skærmen var gået i sort. I følge den sagkyndige erklæring kunne konstateres diverse fejl, som formentlig skyldtes „,ustabilt fungerende komponent/-er og/eller stikforbindelser i forbindelse med systemkortets integrerede grafikkort“. Der var ingen ydre tegn på fald, slag eller anden overlast. Da det ikke fremgik af den sagkyndige erklæring, om det konstaterede kunne henføres til computerens beskaffenhed på leveringstidspunktet, og da denne havde fungeret upåklageligt de første 15 måneder, fandt Forbrugerklagenævnet ikke grundlag for at antage, at der var tale om en oprindelig mangel.

$50 \mathrm{c}$

Sag 403/7-730

Forbrugeren købte den 18. december 2002 en computer og reklamerede over denne den 18 juni, idet computeren „frøs“. Der var knækket et stykke af USB-porten. Producenten erkendte ifølge forbrugeren, at der var en generel komponentfejl ved modellen, som medførte striber på skærmen, forstyrret video, og at pc'en „frøs”. Forbrugeren anførte først den 14. juli 2002, at pc'en også havde de øvrige af producenten nævnte symptomer. Af den sagkyndige erklæring fremgik ifølge nævnets afgørelse, at „det ikke kan udelukkes, at den af klageren påførte beskadigelse har medført den konstaterede fejl på pc’en, om end det skønnes mindre sandsynligt, at dette alene har været årsagen”. Det fremgik endvidere, at den af producenten nævnte generelle komponentfejl ikke med sikkerhed kunne påvises på forbrugerens computer. På den baggrund fandt nævnet det ikke muligt at træffe afgørelse uden en yderligere bevisførelse, som lå uden for rammerne af Forbrugerklagenævnets kompetence. Sagen afvistes derfor.

\section{Norsk ret}

51.

Sak 2000/406

Klageren havde købt en brugt bil til kr. 53.000 den 5. april 1997. Bilen led af en række skavanker, som klageren blev oplyst om i forbindelse med købet. Den 13. august 1999 forsøgte klageren at sælge bilen til en autoriseret forhandler, men denne oplyste klageren om, at bilen højst kunne sælges for kr. 5.000 til en privat bruger. Klageren reklamerede den 26. august 1999 til forhandleren og bad denne om at udbedre de mangler, som var konstateret allerede ved købet i 1997. Alternativt ville klageren have forhandleren til at dække differencen mellem markedsprisen og den pris, hun ville have fået uden manglerne. Forbrukertvistutvalget udtalte, at det måtte lægges til grund, at en otte år gammel bil, som havde kørt 128.000 $\mathrm{km}$, må kunne forventes at have en levetid, som er væsentlig længere end to år ved normal brug. Der gjaldt derfor en absolut reklamationsfrist på fem år fra leveringen. Da der forelå en mangel, og da klageren havde reklameret rettidigt, havde klageren ret til et forholdsmæssigt afslag på kr. 15.000. 
Klageren havde købt et par briller for kr. 3.907 den 18. juli 1998. Lakken blev imidlertid slidt af flere steder på indfatningen, og den 22. juli 2002 reklamerede klageren derfor til forhandleren. Forbrukertvistutvalget fandt, at det ikke kunne udelukkes, at der fandtes enkelte brilleindfatninger, som måtte kunne forventes at have en levetid på mere end to år, men klageren havde ikke godtgjort, at dette gjaldt for klagerens briller. At lakken er slidt af efter fire års brug udgjorde derfor ingen mangel, og klageren havde derfor ingen misligholdelsesbeføjelser.

53.

Sak 2004/151

Klageren havde købt en mobiltelefon for kr. 1.969. Klageren anførte i sin klage, at telefonen hele tiden havde haft en dårlig dækning, hvilket medførte, at den gik ud, afbrød samtaler og gengav lyden dårligt. Han indleverede derfor telefonen til reparation, og telefonen havde nu været sendt til reparation tre gange for de samme mangler. Klageren indgav sin klage imod såvel den norske forhandler som mobiltelefonens finske ophav. Forbrukertvistutvalget fandt, at der var værneting i Norge for så vidt angår mobiltelefonens finske ophav efter den norske tvistemålslov § 25, idet hovedforpligtelsen skulle præsteres i Norge. Udvalget fandt endvidere, at sagen skulle afgøres efter norsk køberet, og baserede sin afgørelse heraf på renvoi-betragtninger. Det blev ligeledes fastslået, at mobiltelefoner efter udvalgets opfattelse ved vanlig brug skal kunne holde væsentligt længere end to år. Der gælder derfor en absolut reklamationsfrist på fem år for mobiltelefoner. Klageren havde reklameret inden udløbet af denne frist. Da der var tale om en væsentlig mangel, kunne klageren herefter hæve købet og kræve sine penge retur.

54.

Sak 2004/256

Klageren havde købt en Sony Playstation 2 for kr. 2.685 den 2. november 2001. Den 1. marts 2004 ophørte maskinen med at fungere, idet den ikke længere ville læse Playstation 2-spil. Klageren reklamerede derfor til forhandleren, som den 5. marts 2004, uden at have foretaget nogen undersøgelse af maskinen, antog, at problemet skyldtes en fejl på laseren. Klageren var enig i, at problemet højst sandsynligt skyldtes en fejl på laseren, men ønskede ikke at betale de kr. 400, som det ville koste at undersøge maskinen. Reparationen ville beløbe sig til ca. kr. 2.500. Forbrukertvistutvalget fandt, at en Playstation 2 har en forventet levetid på mere end to år ved sædvanlig brug. Maskinen omfattedes derfor af den absolutte femårige reklamationsfrist. Herefter udtalte udvalget: „Ifølge Høyesteretts dom i Rt. 1998 s. 774 samt Forbrukertvistutvalgets tidligere praksis vil feil som oppstår i løpet av femårsperioden på produkter som faller inn under denne regelen, bli ansett som kjøpsrettslige mangler, medmindre det er grunnlag for å mene at feilen er en følge av normal slitasje, brukerfeil f.eks. ytre påvirkninger av forskjellig type“. Da der ikke var holdepunkter for at antage, at brugen af maskinen havde været usædvanlig, fandtes maskinen at lide af en mangel, og klageren, der havde reklameret rettidigt, kunne kræve omlevering.

55.

FTU sak 20040356

En forbruger, A, købte i februar 1999 et tv. Der blev givet 24 måneders garanti. I sin klage til Forbrukertvistutvalget angav A, at skærmen blev sort i januar 2003. Tre dage efter at have konstateret dette, reklamerede A til sælgeren, B. A fik øjen- 
synligt det indtryk, at en eventuel reparation ville være omkostningsfri. Da han senere fik besked om, at tv'et nu var repareret, var beskeden, at der han skulle betale reparationsomkostningerne. A klagede herefter til Forbrukertvistutvalget med krav om omkostningsfri reparation.

Forbrukertvistutvalget fastslog at, TV-apparater måtte anses for omfattet af den 5årige reklamationsfrist. Herefter udtalte udvalget: „Ifølge Høyesteretts dom i Rt. 1998 s. 774 samt Forbrukertvistutvalgets tidligere praksis vil feil som oppstår i løpet av femårsperioden på produkter som faller inn under denne regelen, bli ansett som kjøppsrettslige mangler, medmindre det er grunnlag for å mene at feilen er en følge av normal slitasje, brukerfeil f.eks. ytre påvirkninger av forskjellig type“. B havde „antydet“, at fejlen skyldtes støvansamlinger ud over det normale, men dette var ikke bekræftet fra sagkyndigt hold. På denne baggrund fndt Forbrukertvistutvalget, at tv'et led af en mangel, som A i henhold til kjøpslovens § 34, stk. 1, havde krav på blev afhjulpet uden omkostninger. Da reparationen var foretaget, skulle A have tv'et udleveret uden at betale noget herfor.

56.

FTU sak 20040176

En forbruger, A, købte i november 1998 en vaskemaskine. Midt i et vaskeprogram ophørte maskinen med at fungere i september 2003. Den virkede nu alene, hvis A holdt start-/sluk knappen inde under vasken. A indleverede maskinen til sælgeren, B, med henblik på reparation. Knappen blev udskiftet, og B afkrævede A omkostningerne til reparationen. Sagen blev forelagt Forbrukertvistutvalget, hvor A krævede omkostningsfri afhjælpning. Forbrukertvistutvalget konstaterede, at vaskemaskinen måtte anses for omfattet af 5-årsreklamationsreglen. Herefter udtalte udvalget: „Ifølge Høyesteretts dom i Rt. 1998 s. 774 samt Forbrukertvistutvalgets tidligere praksis vil feil som oppstår i løpet av femårsperioden på produkter som faller inn under denne regelen, bli ansett som kjøppsrettslige mangler, medmindre det er grunnlag for å mene at feilen er en følge av normal slitasje, brukerfeil eller annet forhold som kjøperen selv har risikoen for, f.eks. ytre påvirkninger av forskjellig type“. Udvalget konstaterede, at der i den foreliggende sag er „ingenting, som tyder på, at klagerens bruk eller andre ytre påvirkninger har ført til, at av/påknappen har sluttet å virke“. På den baggrund fandt udvalget, at der forelå en mangel, som måtte anses for at have været til stede ved leveringen. A havde derfor krav på omkostningsfri reparation, jf. kjøpslovens § 34, stk. 1 .

57.

FTU sak 20030263

En forbruger, A, købte i juni 1998 en strygepresser. Apparatet blev indleveret til reparation tre gange i løbet af reklamationsfristen på fem år. A blev afkrævet reparationsomkostninger af sælgeren, B. Sagen blev forelagt Forbrukertvistutvalget, hvor A krævede at få sine reparationsomkostninger dækket af B. Forbrukertvistutvalget konstaterede, at varen måtte anses for omfattet af den 5-årige reklamationsfrist. Herefter konstaterede udvalget: „Ifølge Utvalgets tidligere praksis vil feil som oppstår i løpet av femårsperioden på produkter som faller inn under denne regelen, bli ansett som kjøppsrettslige mangler, medmindre det er grunnlag for å mene at feilen er en følge av normal slitasje, brukerfeil eller annet forhold som kjøperen selv har risikoen for, f.eks. ytre påvirkninger. Utvalget viser i denne forbindelse også til Høyestretts dom i Rt. 1998.774 i en sak som gjelder en videospiller“. Såvel indklagede som prodcent gav i sagen udtryk for, at fejlene skyldtes manglende veligeholdelse og andre brugerfejl. Da disse årsagsforklaringer imilderid ikke bava dokumenterede eller sandsynliggjort, fandt utvalget, at der i alle tre 
tilfælde havde været tale om mangler, som A derfor havde krav på at få afhjulpet omkostningsfrit. A havde derfor krav på at få reparationsomkostningerne dækket af B.

58.

FTU sak 20040151

En forbruger, A, købte i juni 2001 en Nokia mobiltelefon for NOK 1.969. A påstod, at telefonen aldrig rigtig har virket; den har konstant haft dårlig dækning og dårlig lyd. Telefonen blev indleveret til reparation tre gange, men uden held. Sagen blev herefter forelagt for Forbrukertvistutvalget, og A krævede ophævelse af købet samt erstatning, blandt andet for reparationsomkostninger. Forbrukertvistutvalget fandt for det første, at der var værneting i Norge, og at norsk ret fandt anvendelse, uanset om leverandøren af telefonen var hjemmehørende i et andet EU-land. Nokia og andre uudenlandske virksomheder kan derfor indklages for Forbrukertvistutvalget. Udvalget fastslog herefter, at uanset om en leverandør alene har givet en forbruger en produktgaranti i et år, har forbrugerne de rettigheder, som fremgår af kjøpsloven. Det betyder blandt andet, at der er fem års reklamationsret på alle mobiltelefoner. I den konkrete sag fandt udvalget det tilstrækkeligt sandsynliggjort, at led af en væsentlig mangel. Da afhjælpningsforsøgene ikke havde hjulpet, kunne A hæve købet efter kjøpslovens § 39, stk. 1. A fik derudover medhold i sit krav på erstatning for reparationsomkostninger.

59.

FTU sak 20040350

En forbruger, A, købte i december 1999 en bærbar minidisc afspiller. Der blev givet 24 måneders garanti. I juli 2003 forsvandt lyden fra de med afspilleren medfølgende høretelefoner. A reklamerede derfor senere samme måned til sælgeren, B, som sendte afspilleren til undersøgelse. Årsagen til fejlen blev imidlertid ikke fundet. Sagen blev forelagt for Forbrukertvistutvalget, hvor A krævede ophævelse, subsidiært omlevering eller afslag i købesummen. Forbrukertvistutvalget fandt under henvisning til Høyesterettsdommen Rt 1998-774 samt til forbrukertvistutvalgets tidligere praksis, at en minidisc-afspiller måtte anses for omfattet af reglen om fem års reklamationsret. Forbrukertvivstutvalget udtalte herefter: Av denne praksis følger det også at feil som oppstår i løpet av femårsperioden på produkter som faller inn under denne regelen, blir ansett som kjøppsrettslige mangler, med mindre det er grunnlag for å mene at feilen er en følge av normal slitasje, brukerfeil eller annet forhold som kjøperen selv har risikoen for, f.eks. ytre påvirkninger av forskjellig type“. Da der ikke forelå sådanne konkrete holdepunkter, var afspilleren mangelfuld, hvorfor A kunne gøre mangelsbeføjelser gældende, jf. kjøpslovens $\S 30$, stk. 1. Manglen blev anset for væsentlig, og A havde derfor ret til at hæve købet, jf. kjøpslovens § 39, stk. 1. Da A imidlertid havde haft en fuldt funktionsduelig afspiller i 3 1⁄2 år, blev der foretaget et brugsfradrag efter kjøpslovens $\S 65$, stk. 1 på 1/3 af købesummen (NOK 1.000).

60.

Sag Rt 1998.774

Denne sag drejede sig om fejl i en videomaskine, som opstod efter tre et halvt års brug. Det lagdes til grund, at der var tale om en vare, som ved vanlig brug var beregnet til at kunne holde i væsentlig længere tid end to år. 5-års reklamationsfristen fandt derfor anvendelse. Spørgsmålet var, om forbrugeren måtte godtgøre, at manglen havde været til stede ved leveringstidspunktet, eller om der gjaldt en særlig formodning herfor. Til støtte for det sidste henviste forbrugeren til Stortingsudtalelsen citeret ovenfor. Høyesteret anførte imidlertid følgende om udtalelsen: 
„Uttalelsen er etter min mening ikke entydig. Den kan iallfall forstås enten slik at den uttrykker en særlig bevisbyrderegel til fordel for forbrukerkjøpere, eller slik at den uttrykker en alminnelig erfaringssetning om faktiske forhold som må tillegges betydning ved bevisbedømmelsen. Jeg finner det for min del mest nærliggende å forstå uttalelsen på den sidstnevnte måten“. Det afgørende i sagen var efter Høyesteretts opfattelse, at den erhvervsdrivende ikke havde „funnet det formålstjenlig å undersøke IR-mottakeren for eventuelt å klarlegge årsaken til funktionssvikten.“ Sælgeren fandtes herved at have tilsidesat sin „bevisføringspligt“, hvilket måtte belaste sælgeren. Høyesterett fandt det på den baggrund godtgjort, at videomaskinen havde en svaghed ved leveringen, som ledte til svigtet tre et halvt år senere. Da svagheden endvidere måtte karakteriseres som en mangel, fik forbrugeren medhold i sit krav.

\section{Svensk ret:}

$$
\text { 61. } \quad \text { NJA } 1991 \text { s. } 481
$$

En bådmotor blev repareret to gange af den samme reparatør. Ejeren af båden afviste at betale for den anden reparation, da han mente denne havde været nødvendiggjort af fejl begået i forbindelse med den første reparation. Reparatøren hævdede problemet skyldtes vandindtrængning. Ejeren havde bevisbyrden for, at det forholdt sig på denne måde. Beviskravet ansås dog for opfyldt derved, at den af ejeren angivne skadesårsag, på baggrund af en vidneforklaring afgivet af en sagkyndig haveriinspektør, fremstod som klart mere sandsynlig end den af reparatøren angivne. Ejeren af båden fik derfor medhold.

62.

ARN 1993-2722

Forbrugeren købte en ny bil med nybilsgaranti for 79.900 kr. Nogle dage efter købet opdagede han, at det trak med kold luft under rattet, hvorfor han klagede til sælgeren. Sælgeren siliconebehandlede bilen og afviste, at der var tale om en mangel. Forbrugeren fastholdt sin reklamation og bilen blev testet af Svensk Bilprovning, som gjorde anmærkning om koldluftstræk under rattet. Forbrugeren krævede nu ophævelse a købet. Sælgeren gjorde gældende, at trækket måtte skyldes fejlanvendelse. Nævnet udtalte: „, För att säljaren skall undgå att ansvara för ett fel som reklameras under garantitiden måste denne göra sannolikt att felet har uppkommit på grund av en omständighet som är att hänföra till köparen“ . Nævnet fandt under hensyntagen til Bilprovningens udtalelse og sælgerens afhjælpningsforsøg samt sælgerens undladelse af at tilvejebringe modbevis, at koldlufttrækket måtte anses for en mangel. Nævnet tilføjede endvidere, at sælgeren , har inte heller genom någon utredning förmått göra sannolikt att felet är att hänföra till F“. På den baggrund fik forbrugeren medhold i sit krav.

63.

ARN 1992-5239

Forbrugeren købte en vaskemaskine. Efter under to gik den i stykker og forbrugeren reklamerede inden for toårsfristen. ${ }^{70}$ Det viste sig, at „packboxen“ og kuglelejet i maskinen var gået i stykker. Nævnet udtalte: „Det är i princip köparens sak att visa att felet fanns vid levernsen. Beviskravet när det gäller tekniska fel kan dock inte ställas alltför högt vis konsumentköp. I det aktuella fattet har felet visat

\footnotetext{
${ }^{70}$ Der var givet en et-årig garanti, men denne fik ingen betydning for sagen, da der reklameredes efter et år men inden for den almindelige to-års frist.
} 
sig på det sättet att en packbox och ett kullager gått sönder. Enligt nämndens mening framstår det som mera samnnolikt att detta beror på ett fel som fanns redan vid leveransen än på någon senare inträffad omständighet av det slag som säljaren angett som mögligt, d.v.s. att klädludd, trådar eller liknande kommit in i maskinen. Beviskravet för därmed anses uppfyllt“. Forbrugeren fik herefter medhold i sit krav om afhjælpning.

64.

ARN Sag 2004-3578

En forbruger, A, købte i oktober 2002 en lædersofa til SEK 22.100. Et år efter købet opdagede A første gang, at sofaen tabte sin farve/smittede af. Fejlen blev afhjulpet, men kom tilbage. A krævede derfor omlevering eller alternativt ophævelse af købet. Sælgeren, B, bestred A’s krav, og henviste især til, at fejlen var opstået som følge af A's brug. Nævnet udtalte, at det er forbrugeren, som skal bevise, at der foreligger en mangel. Nævnet fandt ikke at køberen „på den befintliga utredningen och mot säljerens bestridende har kunnat bevisa dette“. A’s krav blev derfor afvist.

65.

ARN sag 2004-5696

En forbruger, A, købte i november 2003 et akvarium hos sælgeren, B. I marts 2004 var akvariet blevet utæt. Akvariet blev indleveret i B, og mens A afventede B’s undersøgelse af akvariet, lånte hun et ældre akvarium af B. Dette akvarium forårsagede senere en vandskade hos A som følge af en revne i bunden. Skaden beløb sig til SEK 2.000, som A krævede, at B betalte. B afviste dette. A anførte, at akvariet formentlig ikke havde været prøvefyldt med vand inden det forlod forretningen, idet hun $\mathrm{A}$ havde måttet tømme det for savspåner og gøre det rent derhjemme. B havde til dette sagt ,att vi har fler djur än fiskear i våra akvarier“. A kunne ikke på denne baggrund anses for at have bevist, at det lånte akvarium var mangelfuldt ved leveringen. Der kunne derfor ikke gives A medhold i kravet.

66.

ARN Sag 2004-8066

En forbruger, A, købte i januar 2004 en projektor af sælgeren, B. Efter 456 timers brug (efter ca. ni måneder) gik pæren i stykker. Af garantivilkårene for projektoren fremgik det, at garantien for pæren var seks måneder eller 2.000 timer. Af fabrikantens hjemmeside fremgik det, at levetiden for pæren var 3.000 timer. A forlangte herefter omlevering. Han gjorde gældende, at projektoren kun havde fungeret i $15 \%$ af den garanterede brændtid. I den konkrete sag fandt nævnet imidlertid, at garantitiden - uanset hvilken levetid for pæren, som A var stillet i udsigt var udløbet, da A først reklamerede ni måneder efter købet. Uden for garantitilfælde er det afgørende, om fejlen forelå på leveringstidspunktet. Det er som udgangspunkt forbrugeren, som skal bevise, at dette var tilfældet. Nævnet udtalte: På den i ärendet föreliggenda utredningen kan inte nämnden finna att Marcus Månsson - mot företagets bestridande - har förmått göra övervägande sannolikt att felet beror på något ursprungligt fel hos lampan“. Kravet blev derfor afvist.

67.

ARN Sag 2005-3753

En forbruger, A, købte i september 2004 en pc af sælgeren, B. I marts 2005 reklamerede A til B over, at pc'en låste, og at displayet udviste underlige farver. B svarede, at pc'en var skadet som følge af at være tabt, og at reparationen derfor ikke kunne udføres inden for garantien. A afviste at have tabt pc'en. A forlangte 
omlevering, alternativt afhjælpning. Nævnet udtalte, at har en sælger afgivet garanti, kan han kun undgå sit garantiansvar, hvis han kan dokumentere, at fejlen er opstået som følge af forbrugerens adfærd. Ved en samlet bedømmelse i den konkrete sag - hvor nævnet blandt andet inddrog fotos af skaden/displayet - anså nævnet det overvejende sandsynligt, at fejlen i displayet er opstået, mens pc'en var i A’s varetægt. Fejlen kunne derfor henføres til A’s adfærd, hvorfor A’s krav blev afvist.

Uforholdsmeessighedsvurderingen

68.

Sag 2003-4051/7-260

En forbruger, A, havde købt en mobiltelefon. Telefonen kunne ikke indlæse SIM kortet. Den erhvervsdrivende, B, forsøgte afhjælpning ved en reparation, som tog 14 dage, men telefonen ville fortsat ikke indlæse SIM kortet. Forbrugeren hævede derfor købet. B nægtede at efterkomme A’s krav om ophævelse af købet, og tilbød i stedet endnu et afhjælpningsforsøg. Forbrugerklagenævnet fandt, at der var tale om en væsentlig mangel, og da B ikke havde godtgjort, at manglen ikke kunne have været afhjulpet allerede i første forsøg, hvortil kom, at B alene havde tilbudt afhjælpning og ikke omlevering, havde A ikke pligt til at tåle endnu et afhjælpningsforsøg, og købet kunne derfor hæves.

69.

Sag 2002-4051/7-93

En forbruger, A, havde købt en mobiltelefon, der halvanden måned efter leveringen begyndte periodisk at slukke ved afsendelse af sms-beskeder. Den erhvervsdrivende, B, henviste A til at få fejlen afhjulpet i en Nokia Butik. Fejlen viste sig imidlertid atter to uger efter, A havde fået mobiltelefonen retur fra butikken. A krævede herefter mobiltelefonen omleveret. B lod mod A's protest fejlen afhjælpe under henvisning til, at producenten ville udbedre fejlen uden udgift for A. A fastholdt imidlertid sit krav om omlevering. Forbrugerklagenævnet fandt for det første, at A havde reklameret rettidigt. Herefter konkluderede nævnet, at A havde ret til at hæve købet, idet en ombytning alene ville påføre B en merudgift på kr. 156. Der blev ved vurderingen af omkostningerne ved omlevering i forhold til omkostningerne ved afhjælpning lagt vægt på, at den defekte mobiltelefon kunne istandsættes og gensælges som lettere brugt, hvorved B’s udgift til omlevering blev reduceret. Nævnet fremhævede udtrykkeligt, at der hverken i lovens forarbejder eller i øvrigt var grundlag for i uforholdsmæssighedsvurderingen at tage hensyn til, at indklagede ikke kunne opnå avance ved salg af ombytningstelefonen. Herudover bemærkede nævnet, at da indklagede allerede én gang havde haft mulighed for at afhjælpe manglen, ville der skulle meget til, for at fravige udgangspunktet om forbrugerens valgret. Nævnet bemærkede derudover, at afhjælpning ikke var sket inden rimelig tid, og at et krav om omlevering derfor også kunne støttes på købelovens § 78, stk. 4.

70.

Sag 2003-642/7-23

En forbruger, A, fik forlænget et armbånd ved købsaftalens indgåelse. Kort tid efter knækkede armbåndet tre steder. Forbrugerklagenævnet konstaterede, at der som følge af forlængelsen var tale om et specieskøb. Omlevering var derfor ikke mulig. Den erhvervsdrivende, B, kunne afværge A's krav om ophævelse ved at foretage afhjælpning inden rimelig tid. 
71.

Sag (ikke nummereret)

En forbruger, A, købte i juli 2002 en harddisk til DKR 937. Efter et år virkede harddisken ikke længere efter hensigten, og A indleverede den derfor til den erhvervsdrivende, B. 1 1 1/2 måned efter indleveringen meddelte B A, at harddisken ikke kunne repareres. B ville foretage ombytning til en anden model fra samme producent med samme specifikationer, idet den købte model ikke længere blev produceret eller alternativt give A et tilgodebevis på værdien af denne svarende til ca. halvdelen af den oprindelige købesum. A ønskede ombytning til præcis samme model. Da dette ikke blev imødekommet, hævede A købet. Forbrugerklagenævnet konstaterede - på baggrund af en sagkyndig erklæring - at den harddisk, B havde tilbudt at bytte med, var en ny udgave, som ikke havde helt de samme specifikationer som den først leverede harddisk, men at forskellene var så små, at det ikke ville kunne registreres under normal brug. B fandtes derfor at have tilbudt at ombytte harddisken med en ny harddisk, som reelt var overensstemmende med, hvad A ifølge købsaftalen og de ved købet foreliggende omstændigheder havde været berettiget til at forvente af den købte genstand. A var derfor ikke berettiget til at hæve købet.

Sag 2002/4051/7-1312

En forbruger, A, havde købt en mobiltelefon, hvor displayet få måneder efter købet ophørte med at virke. Den erhvervsdrivende, B, reparerede displayet. Problemet opstod imidlertid atter, og A krævede derfor købet ophævet. B nægtede dette, men tilbød i stedet igen afhjælpning. Forbrugerklagenævnet konstaterede for det første, at der var tale om en væsentlig mangel, og at A derfor som udgangspunkt havde ret til at kræve købet ophævet. Herefter udtalte nævnet, at afværgelse af ophævelse forudsatte, at køberen havde fået valget mellem afhjælpning og omlevering, medmindre sælgeren kunne godtgøre, at den ene beføjelse ville være uforholdsmæssig, idet han i så fald ville kunne nøjes med at tilbyde den anden. Da sælgeren alene havde tilbudt afhjælpning og ikke havde godtgjort, at omlevering ville påføre ham uforholdsmæssige omkostninger, havde han ikke godtgjort, at tilbudet om afhjælpning var tilstrækkeligt til at afværge ophævelse. Køberen var derfor berettiget til at hæve.

73.

Sag 2002-4051/7-1341

En forbruger, A, købte en mobiltelefon, hvor bagbeklædningen efter halvanden måned gik løs. A krævede derfor telefonen omleveret. Den erhvervsdrivende, B, oplyste, at det var nødvendigt at lade telefonen undersøge på et værksted for at afgøre, om den skulle omleveres. En sådan undersøgelse ville tage ca. 14 dage. A blev ikke tilbudt en erstatningstelefon. A fastholdt kravet om omlevering og indbragte sagen for Forbrugerklagenævnet, hvis sagkyndige oplyste, at en reparation ville koste ca. kr. 300. Ved uforholdsmæssighedsvurderingen lagde forbrugerklagenævnet vægte på, at der var tale om en genstand, som forbrugeren havde daglig brug for, og at forbrugeren hverken var blevet tilbudt øjeblikkelig reparation eller en erstatningstelefon. Der ville herefter - efter nævnets opfattelse - skulle meget til for at fravige udgangspunktet om forbrugerens valgret. Da den ombyttede telefon ville kunne repareres og herefter gensælges som lettere brugt, fandt nævnet efter en samlet vurdering, at B - selv om den foreliggende mangel kunne afhjælpes for et mindre beløb - ikke havde godtgjort, at den beføjelse, som A havde valgt (omlevering), ville påføre B uforholdsmæssige omkostninger. A's omleveringskrav var derfor berettiget. 
En forbruger, A, købte et par kraftige sko. Under en rejse faldt gummihælene af, og A foretog derfor en nødtørftig limning og fortsatte herefter med at bruge dem. Da han var kommet hjem reklamerede han i forretningen, som udførte en fagmæssig limning. A krævede herefter omlevering eller ophævelse af købet, hvilket den erhvervsdrivende, B, afviste. Forbrugerklagenævnet konstaterede, at skoene havde lidt af en mangel, som dog nu måtte anses for afhjulpet. Nævnet lagde derefter til grund, at A efter manglens konstatering selv havde forsøgt limning med skade på skoene til følge, ligesom det måtte lægges til grund, at A fortsatte med brugen af skoene. Da A som følge heraf ikke havde været i stand til at tilbagegive skoene i væsentlig samme stand, fulgte det allerede heraf, at B ikke havde haft pligt til at tilbyde A omlevering. Nævnet fandt endelig, at da B efter det oplyste havde afhjulpet manglen på tilfredsstillende måde inden rimelig tid efter A's reklamation, kunne der ikke gives A medhold i kravet om omlevering eller ophævelse af købet.

75.

Sag 2003-62/7-70: køb af støvler

En forbruger, A, købte et par støvler, som efter ca. 4 måneders brug gik fuldstændigt fra i læder og sål. A reklamerede til den erhvervsdrivende, B, og det blev aftalt, at en skomager skulle vurdere skaden for at bekræfte, at støvlerne var helt slidt op. Da A hentede støvlerne, var de uden samtykke blevet repareret. A ønskede omlevering i stedet for afhjælpning, hvilket B afviste. Forbrugerklagenævnet udtalte, at støvlerne havde været mangelfulde, men at manglen nu var afhjulpet. Der blev herefter lagt afgørende vægt på, at støvlerne fremtrådte som godt brugte og dermed som værende brugt en væsentlig del af deres forventede levetid. Støvlernes værdi uden manglen måtte derfor anses for beskeden, og manglen var af en karakter, som det var muligt at afhjælpe inden rimelig tid. Nævnet lagde derfor til grund, at en omlevering ville have påført B uforholdsmæssige omkostninger, hvorfor B ikke havde haft pligt til at tilbyde A omlevering. Efter afhjælpningen fremstod støvlerne med en mindre kosmetisk fejl, som dog ikke berettigede til ophævelse, men derimod til et mindre afslag i købesummen (kr. 150).

76.

Sag 2003-650/7-151

Klageren havde købt nogle møbler til en samlet pris af kr. 43.865 den 23. april 2002. Den 1. oktober 2003 konstaterede klageren, at der var mange smårevner i møblerne og reklamerede herefter angiveligt til den erhvervsdrivende. Da klageren ikke hørte noget fra den erhvervsdrivende, kontaktede klageren ham igen i april 2003 med krav om omlevering. Den erhvervsdrivende afviste reklamationen, og klageren indbragte herefter sagen for Forbrugerklagenævnet. Forbrugerklagenævnet udtalte, at det ikke var dokumenteret, at der var reklameret over mangler ved møblerne tidligere end i april 2003. Dette forhindrede imidlertid ikke klageren i at reklamere over fejlene, som efter en sagkyndigs vurdering skyldtes materialeog fabrikationsfejl. Møblerne måtte derfor anses for mangelfulde, men da omlevering måtte anses for at påføre den erhvervsdrivende uforholdsmæssige omkostninger, bestemte nævnet, at klageren måtte lade sig nøje med et passende afslag på kr. 10.000 .

77.

Sag 4051/7-496

Klageren havde købt en mobiltelefon til kr. 3.574. Cirka et år efter opstod der fejl ved telefonen, Klageren henvendte sig til en autoriseret reparatør, som opdaterede 
telefonen, hvorved fejlen forsvandt. Knap to år efter købet reklamerede klageren atter over nogle fejl. Klageren forlangte nu omlevering, mens den erhvervsdrivende tilbød afhjælpning. Forbrugerklagenævnet udtalte, at da fejlen, som udgjorde en mangel, først viste sig på et tidspunkt, hvor telefonen havde været i brug i næsten to år, og hvor telefonens vedligeholdelsesstand var under middel med tydelig slitage, var indklagede berettiget til som udgangspunkt at afvise klagerens ombytningskrav, da fejlen viste sig første gang. Den erhvervsdrivende havde imidlertid ikke afhjulpet manglen, og da der heller ikke var tilbudt øjeblikkelig afhjælpning, kunne den erhvervsdrivende ikke antages at have afhjulpet manglen inden for rimelig tid og uden væsentlig ulempe for klageren, som derfor kunne ophæve købet.

78.

Sag 4031/7-496

Klageren havde købt en pc for kr. 10.216. Ca. tre uger efter købet ophørte pc'en med at virke. Klageren reklamerede og indleverede pc'en til den erhvervsdrivende. Efter 4 dage fik klageren pc'en retur. Pc'en var stadig ikke i orden. Klageren reklamerede derfor til den erhvervsdrivende og ønskede at hæve købet. Den erhvervsdrivende afviste dette og tilbød igen afhjælpning. Forbrugerklagenævnet udtalte, at det var op til den erhvervsdrivende at godtgøre, at der ikke havde været pligt til at tilbyde omlevering som følge af, at denne beføjelse ville påføre den erhvervsdrivende uforholdsmæssige omkostninger. Et flertal i nævnet fandt det, under hensyntagen til pc’ens værdi og en sagkyndiges vurdering, godtgjort, at den erhvervsdrivende havde været berettiget til alene at tilbyde afhjælpning, da det ville have været uforholdsmæssigt for den erhvervsdrivende at foretage omlevering i forhold til afhjælpning. Henset til, at den erhvervsdrivende havde haft et afhjælpningsforsøg, som tog fire dage, fandt flertallet, at den erhvervsdrivendes yderligere tilbud om afhjælpning havde været berettiget. Et mindretal fandt klageren berettiget til at hæve.

79.

$$
\text { Sag 4031/7-1146 }
$$

En forbruger klagede efter to måneder over en printers farveskrift, idet sort/hvide fotos nærmest blev udskrevet i farve, mens den blå farve slet ikke blev udskrevet. Der var enighed om, at der forelå en mangel, og forbrugeren krævede omlevering. Spørgsmålet var, om sælgeren kunne afvise dette under henvisning til en uforholdsmæssighedsbetragtning. Forbrugerklagenævnet fastslog her, at udgangspunktet er valgret for forbrugeren, og at det er sælgeren, der har bevisbyrden for, at der foreligger uforholdsmæssighed. Dernæst fastslog man, at det forhold, at en mangel lader sig afhjælpe let eller billigt ikke uden videre er tilstrækkeligt til, at et krav om omlevering kan anses for uforholdsmæssigt, ,idet de ved vurderingen tillige må tages hensyn til forbrugerens interesse i den valgte beføjelse, ligesom det vil skulle indgå i vurderingen, hvilke muligheder sælgeren har med hensyn til at reparere og sælge den ombyttede genstand til anden side som lettere brugt“. Nævnet lagde endvidere til grund, at merudgiften ved omlevering frem for reparation måtte beregnes som forskellen mellem indkøbsprisen på 706,76 kr. for en ny printer og videresalgsprisen for den reparerede printer. Da klageren havde købt en genstand, som han dagligt havde brug for, fandtes et omleveringskrav ud fra en samlet vurdering ikke uforholdsmæssigt.

80.

Sag 2003-4012/7-300

En forbruger havde købt et fjernsyn som en demonstrationsmodel til $11.999 \mathrm{kr}$., idet der blev indrømmet et prisnedslag på 14.000 kr. Fjernsynet gik efter kort tid i 
stykker, og forbrugeren indleverede det til den erhvervsdrivende med anmodning om afhjælpning af manglen. Den erhvervsdrivende meddelte senere, at det ikke kunne lade sig gøre at afhjælpe, hvorfor forbrugeren i stedet kunne få sine penge tilbage eller mod merbetaling få et tilsvarende fjernsyn i en ny serie. Forbrugeren bad i stedet om at få fjernsynet tilbage, hvilket imidlertid ikke kunne lade sig gøre, da den erhvervsdrivende havde kasseret fjernsynet og meddelte, at han havde hævet handlen. Nævnet fandt, at der var tale om et specieskøb, og at den erhvervsdrivende, eftersom han havde kasseret fjernsynet, ikke havde godtgjort, at afhjælpning ville have påført ham uforholdsmæssige omkostninger i forhold til „en“ anden beføjelse. Et flertal i nævnet fandt herefter, at forbrugeren var berettiget til erstatning for fjernsynets værdi, da der var handlet ansvarspådragende ved den uretmæssige ophævelse og kasseringen af fjernsynet.

\section{Norsk ret:}

81.

Sag 2003/070

Klageren havde købt en mobiltelefon til kr. 2.189. Ca. 16 uger efter leveringen henvendte klageren sig til forhandleren, ide en af knapperne på telefonen delvist var ophørt med at fungere. Klagerens krav om omlevering blev efter det oplyste afvist af forhandleren med den begrundelse, at han ønskede at afhjælpe manglen. Telefonen blev herefter repareret. Da den kom tilbage, led den imidlertid efter klagerens opfattelse af andre mangler, herunder at lyset i displayet ikke fungerede ordentligt. Klageren indleverede herefter atter telefonen til forhandleren og krævede omlevering, hvilket blev afslået. Forbrukertvistutvalget afgjorde sagen på baggrund af klagerens sagsfremstilling, idet forhandleren ikke har svaret på udvalgets henvendelser. Telefonen blev herefter anset for mangelfuld, og da klagerens krav om levering ikke medførte uforholdsmæssige omkostninger for forhandleren, havde klageren ret til en ny telefon.

82.

Sak 2003/106

Klageren havde købt et par støvler til kr. 1360. Kort tid efter købet faldt den ene hæl af. Forhandleren tilbød afhjælpning, men klageren ønskede at hæve købet, hvilket forhandleren, efter det af klageren oplyste, havde lovet klageren, at hun kunne, hvis hælen mod forventning skulle falde af. Klageren ønskede derfor nu i det mindste omlevering.

Forbrukertvistutvalget fandt ikke, at klagerens krav om omlevering medførte uforholdsmæssige omkostninger for forhandleren, og henviste i den forbindelse blandt andet til, at der var tale om en masseproduceret vare, som sædvanligvis lagerføres af forhandlere.

Sagen blev herefter indbragt for tingsretten, som nåede til det modsatte resultat. Retten fandt, at det „i den aktuelle sammenhengen“ ikke naturligt „å karakterisere støvletter i den aktuelle prisklasse som en masseprodusert forbruksvare med beskjeden verdi“. Retten tilføjede: „Dersom kunden i et tilfelle som det omhandlede skulle ha et ubetinget krav på omlevering, kun ut fra verdien på varen, ville det innebære at stort sett alle sko, en rekke klær m.v. som hadde en mangel, ville bliv vraket. Retten finder dette bl.a. strider mod det miljøhensyn, som skal hensyntas. Dette gjelder spesielt dersom forholdet er, at mangelen kan utbedres raskt og på en fullgod måte“. Afgørende for retten var herefter, at meromkostningerne ved omlevering set i forhold til afhjælpning udgjorde 380 NKR, svarende til det seksdobbelte af afhjælpning, og at disse omkostninger måtte anses for uforholdsmæssige, når det blev taget i betragtning, at manglen ville kunne udbedres på 
2-3 dage, og at støvletten efter en udbedring både kvalitetsmæssigt og udseendemæssigt ville være lige så gode som et par nye støvletter.

Sagen blev anket til Lagmannsretten, som ændrede tingsrettens afgørelse. Lagmannsretten slog fast, at uforholdsmæssighedsvurderingen indebærer en „bred og sammensatt vurdering“ med udgangspunkt i om sælgerens omkostninger ved omlevering vil være urimelige set i forhold til en reparation. Man fastslog endvidere, at direktivets tre kriterier er centrale men ikke udtømmende. Lagmannsretten lagde herefter til grund, at de faktiske omkostninger ved en omlevering af støvletterne ville beløbe sig til 447 NKR. Dette beløb ville efter lagmannsrettens opfattelse isoleret set ikke være en urimelig omkostning „selv om beløbet er vesentlig høyere enn selgerens kostnad ved reparasjon“. Retten inddrog herefter direktivets tre kriterier, og fandt i relation til værdien af varen i manglfri tilstand, at verdien af et par støvletter til 1360 NKR ikke var betydelig set i sammenhæng med, at forbrugerkøb kan omfatte køb af genstande til flere hundredetusindekroner. I relation til betydningen af manglen, fandt retten, at denne var væsentlig, idet manglen havde betydning for varens funktion. For så vidt angik spørgsmålet om muligheden for at gennemføre den alternative beføjelse (afhjælpning) uden ulempe for forbrugeren, fandt retten, at afhjælpning ville kunne gennemføres uden væsentlig ulempe for forbrugeren. Endelig inddrog lagmannsretten som et yderligere kriterium det miljømæssige hensyn, men anførte her, at dette ikke entydigt talte mod omlevering, da gennemtvingelse af omleveringskrav ville kunne medføre en generelt større kvalitetsbevidsthed hos producenter og dermed medvirke til nedsættelse af antallet af mangelfulde varer. Ud fra en samlet vurdering kom lagmansretten herefetr til, at forbrugeren havde krav på omlevering. Retten fremhævede, at man i denne sammenhæng lagde vægt på „at lovens hovedregel er at forbrukeren har krav på omlevering, og af de derfor skal en del til for at selgeren kan møte dette kravet med et tilbud om reparasjon. Særlig må dette gjelde innenfor et så sentralt området for forbrukerkjøp som kjøp av sko“. Lagmannsretten fremhævede endvidere, at det i den konkrete sag var helt centralt, at manglen var væsentlig, og på det generelle plan, at det var vigtigt at have regler og praksis, „som er lette og enkle å praktisere“ for at undgå at gøre forbrugerens valgret mindre reel.

Sagen blev anket til Høyestrett, som i en 3-2 afgørelse stadfæstede tingsrettens dom og afviste forbrugerens krav på omlevering. Flertallet af dommere lagde vægt på, at det norske urimelighedskriterieum må fortolkes i overenstemmelse med direktivets forholdsmæssighedskriterium, og det afgørende derfor ikke var, at meromkostningsbeløbet i absolut tal alene beløb sig til omkring 400 N.kr., men derimod at omleveringsomkostningerne var 7 gange højere end afhjælpningsomkostningerne. Flertallet anførte endvidere, at spørgsmålet måtte vurderes i et noget bredere perspektivt, og at en udstrakt pligt til omlevering ville indebære, at man „med loven i hånd“ etablerede en „bruk og kast-ordning“, „som det generellt kan være grunn til å ta avstånd fra“. I et obiter dictum anførtes endvidere, at omleveringsomkostninger normalt vil skulle anses for uforholdsmæssigt store (og dermed urimelige), hvis de blot er 2 eller 3 gange så store som afhjælpningsomkostningerne. Forbrugerens krav afvistes herefter. Mindretallet anførte, at også det absolutte merbeløb forbundet med omlevering måtte være relevant ved foretagelsen af forholdsmæssighedsvurderingen, og at miljømæssige betragtninger kun i sager vedrørende visse typer af produkter som hårde hvidevarer taler mod omlevering. I følge mindretallet burde forholdsmæssigehdsvurderingen praktiseres sådan, at forbrugerens valgret som hovedregel slår igennem, når der er tale om „rimeligere, masseproduserte varer, og der reparasjonen ikke kan skje umiddelbart på stedet“. Mindretallet fandt på den baggrund, at forbrugeren måtte gives medhold. 
Klageren havde købt en mobiltelefon til kr. 999. Ca. tre måneder efter købet begyndte telefonen at slukke sig selv. Klageren indleverede telefonen til forhandleren, som efter det oplyste ikke informerede klageren om, at han havde valgmulighed mellem afhjælpning og omlevering. Fejlen blev udbedret, men opstod kort efter igen. Telefonen blev derfor atter indleveret, og forhandleren meddelte nu, at der var fugtskader i telefonen. Forbrukertvistutvalget fandt, at forhandleren ikke havde dokumenteret, at der forelå en fugtskade ved telefonen, og at der ikke var tilstrækkelige holdepunkter for at antage, at klageren havde foretaget en brug af telefonen, som var udover det sædvanlige. Det konstateredes, at klageren havde ret til at vælge mellem afhjælpning og omlevering, og da forhandleren havde nægtet at foretage afhjælpning, kunne klageren hæve købet, idet manglen var væsentlig.

84.

Sak 2004/103

Klageren havde købt en mobiltelefon til kr. 999. Vibratorfunktionen i telefonen virkede ikke efter hensigten. Telefonen blev derfor indleveret til forhandleren, som efter undersøgelse oplyste, at da fejlen skyldtes en fugtskade, afvistes reklamationen. Forbrukertvistutvalget fandt, at det ikke var bevist af forhandleren, at fejlen ved vibratorfunktionen ikke fandtes ved leveringen. Derfor fandtes fejlen at have været til stede ved leveringen. Klageren havde derfor ret til omlevering

\section{Svensk ret:}

Klageren havde købt en barnevogn til kr. 6.600. Efter en måned gik sømmene i stykker på flere steder. Klageren ønskede derfor at hæve købet, alternativt omlevering. Forhandleren afviste klagerens krav men tilbød afhjælpning. Det allmänna reklamationsnämnden fandt, at eftersom fejlen, der måtte anses som en mangel, kunne afhjælpes for et væsentligt lavere beløb end de omkostninger, som ville være forbundet med en omlevering, var forhandleren berettiget til at foretage afhjælpning. Klagerens krav om ophævelse, alternativt omlevering, blev derfor afvist.

86.

Klageren havde købt 8 persienner inklusiv montering for kr. 2.833 i januar 2003. Senere samme måned opdagede han, at persiennerne var dårligt udført, herunder at de enkelte lameller var af forskellig længde. Han reklamerede flere gange og krævede, at fejlene skulle udbedres. Forhandleren lovede ved flere lejlighed udbedring, men intet skete. Det allmänna reklamationsnämnden afgjorde sagen på baggrund af klagerens oplysninger, idet forhandleren ikke havde reageret på nævnets henvendelser. Nævnet fandt, at klageren var berettiget til at kræve omlevering, hvis dette kunne ske uden uforholdsmæssige omkostninger for forhandleren. Klagerens påstand om omlevering blev derfor imødekommet. 
87.

Sag 2002-10-07 2001-7983

Klageren havde købt en sofagruppe for kr. 15.633 i november 1999. I foråret 2001 opdagede klageren, at sofagruppens røde farve var blevet rosa. Hun klagede derfor til forhandleren med krav om, at sofaerne blev ombetrukket. Ifølge klageren gav forhandleren udtryk for, at man heller ikke syntes, at sofaerne så godt ud. Sofaerne skulle angiveligt have en levetid på 10 år. Klageren havde behandlet sofaerne efter forskrifterne. Ved sagens behandling for nævnet afviste forhandleren klagerens krav om afhjælpning, idet klageren efter forhandlerens opfattelse ikke havde behandlet sofaerne efter forskrifterne. Det allmänna reklamationsnämnden fandt, at der forelå en mangel. Da en ombetrækning imidlertid ville belaste forhandleren med uforholdsmæssige omkostninger, måtte klageren nøjes med et forholdsmæssigt afslag på kr. 2.000.

88.

Sag 2003-01-14; 2002-6334

Klageren havde købt et par sko til kr. 795 i september 2002. Kort tid efter løsnede skoenes fodsål sig. Klageren henvendte sig herefter til forhandleren og krævede omlevering. Forhandleren ville imidlertid afhjælpe fejlen. Reparation blev derfor foretaget. Klageren ønskede nu nævnets stillingtagen til, om købet kunne hæves, og om klageren kunne kræve erstatning. Det allmänna reklamationsnämnden fandt, at fejlen, som udgjorde en mangel, var udbedret på tilstrækkelig vis og til en væsentligt lavere omkostning for forhandleren, end en omlevering ville have forårsaget. Klagerens påstand om ophævelse og erstatning blev derfor afvist.

89.

Sag 2003-12-19; 2003-7338

Klageren havde købt et par sko for kr. 3.095. Kort tid efter købet løsnede sålen på den venstre sko sig. Klageren henvendte sig derfor til forhandleren med krav om at få et par nye sko. Alternativt ønskede hun at hæve købet. Forhandleren tilbød afhjælpning. Det allmänna reklamationsnämnden fandt at fejlen, som var en mangel, let kunne afhjælpes på en tilfredsstillende måde, og at sådan afhjælpning kan ske til en væsentligt lavere pris for forhandleren end prisen for en omlevering. Klageren måtte derfor acceptere forhandlerens tilbud om afhjælpning.

\section{Sag ARN 2003-4268}

En forbruger, A, købte i maj 2003 et modem for SEK 990. I slutningen af maj reklamerede A til den erhvervsdrivende, B, da modemet ikke virkede som det skulle. A krævede omlevering eller alternativt at låne et andet modem i reparationsperioden. $\mathrm{B}$ afviste A's krav og modtog alene modemet med henblik på reparation. A købte herefter et andet modem og ønskede derefter at hæve købsaftalen med B. B afviste dette og bemærkede, at det var B, som kunne vælge misligholdelsesbeføjelse for A. Nævnet udtalte, at det fulgte af konsumentköplagen, at kræver en forbruger afhjælpning eller omlevering, kan sælgeren som hovedregel ikke afvise et krav om afhjælpning ved at tilbyde omlevering og omvendt. Kun såfremt forbrugerens krav om afhjælpning eller omlevering vil medføre uforholdsmæssige omkostninger for sælgeren, kan denne vælge en anden beføjelse. Da B i den konkrete sag ikke havde dokumenteret, at omlevering ville medføre uforholdsmæssige omkostninger, og da afhjælpningen havde medført væsentlig ulempe for A, var hun berettiget til at hæve købet. 


\section{Undersøgelsesbegyrer}

\section{Dansk ret:}

91.

Sag 2000-4031/7-1379

Forbrugeren havde købt en cd-recorder. Den erhvervsdrivende havde givet et års garanti mod fabrikations- og materialefejl. Forbrugeren reklamerede inden for garantiperioden over, at recorderen ikke kunne skrive cd'er. Den erhvervsdrivende kunne imidlertid ikke finde fejlen og opkrævede A 249 kr. for undersøgelsen (eftersynet). Forbrugeren bestred kravets berettigelse, krævede købet ophævet og indbragte sagen for Forbrugerklagenævnet. Nævnets sagkyndige havde under sagen heller ikke kunnet konstatere funktionssvigt, men denne udtalte under nævnsmødet, at det ikke kunne udelukkes, at cd-recorderen var behæftet med en periodisk fejl. Nævnet udtalte herefter, at vil en erhvervsdrivende i en garantiperiode kræve betaling for forgæves fejlfinding, må han godtgøre, at det kan bebrejdes forbrugeren, at denne uden grund har indleveret salgsgenstanden til reparation, ligesom det må kræves, at den erhvervsdrivende på forhånd har sikret sig, at kunden er bekendt med, at han risikerer at skulle betale et nærmere angivet beløb, og at forbrugeren har accepteret dette. Det forhold, at hverken den erhvervsdrivende eller den sagkyndige har kunnet finde fejl ved computeren, udelukker ikke, at klageren kan have været udsat for et funktionssvigt af periodisk karakter. Det er derfor ikke godtgjort, at det kan bebrejdes klageren, at han har indleveret computeren til reparation $i$ henhold til garantien

92.

Sag 2003-4031/7-225

En forbruger, A, konstaterede efter montering af et RAM-modul, at dette ikke fungerede og klagede til den erhvervsdrivende, B. A blev opkrævet et undersøgelsesgebyr på $250 \mathrm{kr}$. af B, idet denne mente, at modulet var beskadiget som følge af A's egne forhold. Beskadigelsen af RAM-modulet skete som følge af A's fejlmontering. Forbrugerklagenævnet udtalte, at A ikke havde krav på gratis afhjælpning, idet skaden var forårsaget af A selv. For så vidt angik det opkrævede undersøgelsesgebyr udtalte nævnets faste sagkyndige, der bistod nævnet på mødet, at det blot ved en umiddelbar besigtigelse af RAM-modulet har været muligt for B at konstatere skadens omfang og årsag, og at det dermed ikke har været nødvendigt for B at iværksætte en egentlig undersøgelse af varen. B havde derfor opkrævet et gebyr, som det ville være urimeligt eller i strid med redelig handlemåde at gøre gældende, hvorfor A havde krav på tilbagebetaling.

En forbruger, A, indleverede sin computer til reparation inden for garantiperioden. Fejlbeskrivelsen på den erhvervsdrivende, B’s, serviceseddel angav: »Fryser i Windows“. B’s værksted kunne ikke finde nogen fejl og krævede derfor 625 kr. for undersøgelsen. A bestred kravets berettigelse. Nævnet udtalte, at udtrykket garanti kun må anvendes i forbrugerforhold om erklæringer, som giver modtageren en væsentlig bedre retsstilling end den, forbrugeren har efter lovgivningen. Et garantitilsagn som det, der forelå i denne sag, måtte fortolkes som en garanti mod funktionssvigt i et år efter overgivelsen. A havde derfor været berettiget til at forvente, at B i tilfælde af funktionssvigt i garantiperioden ville udføre den nødvendige fejlfinding og reparation gratis, medmindre han kunne godtgøre, at funktionssvigtet skyldtes uhensigtsmæssig brug eller andre forhold, som ikke var omfat- 
tet af garantien. Det var derfor ikke foreneligt med B's garantitilsagn at kræve vederlag for enhver forgæves fejlfinding. Nævnet bemærkede også, at B for at kunne løfte sin bevisbyrde selv har en væsentlig interesse $\mathrm{i}$ at foretage den nødvendige fejlfinding og bevissikring. Derfor var det nævnets opfattelse, at det er en betingelse for at kræve betaling for forgæves fejlfinding eller for en udført reparation i garantiperioden, at garantigiveren kan godtgøre, enten at det kan bebrejdes køberen, at denne uden grund har indleveret salgsgenstanden til reparation, eller at der er repareret skader, kunden selv er ansvarlig for. Det må derudover kræves, at garantigiveren på forhånd har sikret sig, at kunden er bekendt med, at han risikerer at skulle betale et nærmere angivet beløb, og at kunden har accepteret dette. Det forhold, at undersøgelsen ikke viste fejl ved computeren, udelukkede efter nævnets opfattelse ikke, at A havde været udsat for den beskrevne fejl. Det var derfor ikke godtgjort, at det kunne bebrejdes $\mathrm{A}$, at han havde indleveret computeren til reparation i henhold til garantien. Nævnet konkluderede derfor, at B ikke havde krav på et undersøgelsesgebyr.

94.

Sag 2002-4031/7-2198

En forbruger, A, havde købt et motherboard, som han efter nogen tid sendte til den erhvervsdrivende, B, idet der angiveligt var fejl på boarded. Da A ønskede at afhente motherboardet, krævede B et undersøgelsesgebyr, idet han ikke havde fundet nogen fejl ved varen. A nægtede at betale gebyret og kunne herefter ikke få udleveret motherboardet. A indbragte herefter sagen for Forbrugerklagenævnet. Forbrugerklagenævnet fandt ikke, at A havde godtgjort, at boarded var mangelfuldt, hvorfor A ikke kunne gøre mangelsindsigelser gældende. I relation til gebyret udtalte nævnet, at vil en erhvervsdrivende påberåbe sig at være berettiget til et undersøgelsesgebyr, må den erhvervsdrivende godtgøre, at han er berettiget til et sådant gebyr. Lider en salgsgenstand af mangler, som forbrugeren kan kræve afhjulpet, er den erhvervsdrivende forpligtet til vederlagsfrit at tage stilling til reklamationen og udføre afhjælpningen gratis. Skal den erhvervsdrivende kunne kræve et undersøgelsesgebyr, må det derfor påhvile sælgeren at godtgøre, at der ikke foreligger mangler ved det solgte, og at det i øvrigt er udtrykkeligt aftalt med forbrugeren, at der i denne situation skal betales et undersøgelsesgebyr, da forbrugeren jo ved at kræve afhjælpning ikke har bestilt en ydelse, som der skal betales for. I den konkrete sag havde B hverken bevist, at motherboardet ved leveringen var uden mangler, eller at det var aftalt med A, at denne skulle betale et testgebyr, såfremt $\mathrm{B}$ ikke kunne konstatere mangler ved det solgte. Nævnet fandt derfor, at der herefter ikke kunne gives B medhold i, at det havde været berettiget at afkræve A et undersøgelsesgebyr. B var som følge heraf ikke berettiget til at betinge udleveringen af motherboardet til $\mathrm{A}$ af, at denne betalte et undersøgelsesgebyr på 250 kr. B’s uberettigede tilbageholdelse af motherboardet fandtes endvidere at udgøre en hævebegrundende misligholdelse af købet, og nævnet gav som følge heraf A medhold i dennes krav om at få købesummen på kr. 1.000 refunderet.

95.

$$
\text { Sag 2003-4021/7-45 }
$$

En forbruger, A, beskadigede sit kamera som følge af, at memory-kortet var indsat forkert. Den erhvervsdrivende, B, forlangte forud for undersøgelsen af kameraet et gebyr på kr. 459, såfremt fejlen viste sig at skyldes A’s forhold. A gjorde gældende, at beskadigelsen skyldtes, at brugsanvisningen ikke var udførlig nok og indbragte sagen for Forbrugerklagenævnet. Forbrugerklagenævnte fandt, at ska- 
dens indtræden hovedsagelig måtte anses for at bero på A's egen uforsigtighed og manglende omtanke. Nævnet gav derfor ikke A medhold i, at A kunne gøre mangelsbeføjelser gældende mod B som følge af, at brugsanvisningen havde været mangelfuld. Hvad angår det undersøgelsesgebyr på kr. 459, som B havde betinget sig, såfremt der ikke var tale om mangler, var det ubestridt, at A blev oplyst herom ved kameraets indlevering til undersøgelse. Under hensyn hertil samt til, at skaden på kameraet skyldtes A's egne forhold, var B ikke afskåret fra at opkræve gebyret, forudsat at det ikke oversteg, hvad der måtte anses for et rimeligt vederlag for den af B foretagne undersøgelse. Idet nævnet gik ud fra, at B's værksted havde været nødt til at adskille kameraet for at undersøge skaden og dens omfang, fandt nævnet ikke grundlag for at anfægte gebyrets størrelse, og nævnet kunne derfor heller ikke give A medhold i den del af klagen, som vedrørte det opkrævede undersøgelsesgebyr.

96.

Sag 2003-4021/7-15

Kort tid efter køb af et digitalkamera forsøgte en forbruger, A, at opdatere kameraets firmware via producenten, B's, hjemmeside. Opdateringen mislykkedes, og kameraet fungerede derefter ikke. A indleverede kameraet til sælgeren, C, der konstaterede, at kameraets hovedkort var blevet beskadiget i forbindelse med forsøget på opdatering, og at reparationen ville koste kr. 3.061. A afviste at betale, idet han mente, at reparationen burde udføres gratis, da B burde have oplyst tydeligere om de risici, der var ved opdatering. A blev derefter opkrævet et undersøgelsesgebyr på kr. 744, som han betalte under protest. Forbrugerklagenævnet fandt på baggrund af sagens oplysninger herunder den sagkyndiges erklæring ikke, at skaderne skyldtes mangler ved kameraet, som var til stede på leveringstidspunktet. Der kunne derfor ikke gives A medhold i hans krav mod indklagede om gratis afhjælpning. Hvad angik det omtvistede undersøgelsesgebyr, påhvilede det $\mathrm{C}$ at godtgøre, at han var berettiget til et sådant gebyr. Nævnet udtalte i den forbindelse, at lider en salgsgenstand af mangler, som køberen kan kræve afhjulpet, er sælgeren forpligtet til vederlagsfrit at tage stilling til reklamationen og udføre afhjælpning gratis. Skal sælgeren kunne kræve et undersøgelsesgebyr, må det derfor påhvile sælgeren at godtgøre, at der ikke er mangler ved det solgte. Det må derudover påhvile sælgeren at godtgøre, at det udtrykkeligt er aftalt med forbrugeren, at der i denne situation skal betales et undersøgelsesgebyr, da forbrugeren jo ved at kræve afhjælpning ikke har bestilt en ydelse, som der skal betales for. $\mathrm{C}$ havde ikke bevist, at det var aftalt med klageren, at denne skulle betale et undersøgelsesgebyr, såfremt C ikke kunne konstatere mangler ved det solgte, og A kunne derfor kræve det opkrævede gebyr på kr. 744 tilbagebetalt af sælgeren. ${ }^{71}$

\footnotetext{
${ }^{71}$ For så vidt angår A’s forsøg på at opdatere kameraets firmware, fremgik det af den sagkyndiges oplysninger, at kun en lille del af opgraderingsfilen var kopieret til A's CF-kort. Det fremgik endvidere af oplysningerne fra B's hjemmeside, at B har været bekendt med, at nogle kunder på tidspunktet, hvor A har forsøgt opdatering, havde haft problemer med at fuldføre opdatering af firmware, idet det for disse var umuligt at kopiere firmwaret korrekt til CF-kortet. Det fremgik dernæst, at B i maj 2002 forbedrede opdateringsprogrammet, således at driftsikkerheden i forbindelse med opdatering blev forbedret. Nævnet lagde på denne baggrund til grund, at A's kamera var blevet beskadiget under opdateringen som følge af manglende driftsikkerhed ved B's opdateringsprogram, som således må antages at have været fejlbehæftet. Selv om B på sin hjemmeside havde taget forbehold for, at opdatering af firmware i kameraet skete for kundens egen regning og risiko, indebar dette ikke, at A også accepterede at bære risikoen for tab som følge af, at hjemmesidens opdateringspro-
} 


\section{Norsk ret:}

97.

Sak 2004/057

Klageren havde købt en mobiltelefon til kr. 998. Telefonen „døde“, mens den blev brugt helt sædvanligt. Klageren indleverede telefonen til forhandleren, som fandt fugt i telefonen, og meddelte, at det ikke kunne betale sig at reparere den. Klageren blev afkrævet et undersøgelsesgebyr på kr. 250. Forbrukertvistutvalget fandt, at der ikke var tilstrækkelige holdepunkter for at antage, at klageren havde foretaget en brug af telefonen, som var udover det sædvanlige. Der henvistes herved også til formodningsreglen. Afhjælpning blev ikke anset for relevant, og da der var tale om en væsentlig mangel, kunne klageren hæve købet. Klageren havde derudover krav på tilbagebetaling af undersøgelsesgebyret.

\section{Svensk ret:}

98.

Sag 2002-5388

Klageren havde købt en printer i februar 2000. Hun fik et års garanti. Printeren blev indleveret til reparation i marts 2001, altså efter garantiperiodens udløb. For så vidt angik mangelsspørgsmålet udtalte nævnet, at det som udgangspunkt er køberen, der har bevisbyrden for, at varen var mangelfuld. Under henvisning til NJA 1991 s. 481, fastslås endvidere, at kravet er, ,at köparen skall visa att det är klart mer sannolikt att felet är ursprungligt än att det har uppstått till följd av en omständighet som säljaren inte har att svara för“. Under anvendelse af denne regel vurderede man i den konkrete sag, at forbrugeren ikke havde løftet bevisbyrden og dermed ikke havde krav på afhjælpning. For så vidt angik spørgsmålet om undersøgelsesgebyr udtalte nævnet i forlængelse heraf, at eftersom det ikke var dokumenteret, at klageren var blevet oplyst om, at der ville blive opkrævet et undersøgelsesgebyr, skulle forhandleren tilbagebetale gebyret til klageren. (Fejlens karakter er ikke oplyst, og der gives ingen oplysninger om et evt. indleveringsbevis).

99.

Sag 1999-1369

Klageren havde købt en brugt bil. De faktuelle oplysninger i sagen er yderst fåtallige, men det allmänna reklamationsnämnden udtalte under alle omstændigheder, at forhandleren i denne sag havde ret til at afkræve klageren et undersøgelsesgebyr. Det er ikke klart, om klageren var blevet oplyst herom inden undersøgelsen.

100.

Sag 2003-04-16; 2003-0292

Klageren havde købt en mobiltelefon for kr. 1.395 i februar 2001. Hun fik tre års garanti. I december 2002 indleverede hun telefonen til forhandleren, idet knapperne og mikrofonen ikke virkede tilfredsstillende. Forhandleren oplyste, at telefonen led af en fugtskade, og at den derfor ikke kunne repareres. Klageren blev derudover afkrævet et undersøgelsesgebyr på kr. 395. Klageren ville have telefonen tilbage uden at betale gebyr. Forhandleren henviste til, at det fremgik af indleve-

gram var fejlbehæftet. B var derfor erstatningsansvarlig over for A for det tab, der derved blev påført ham. Erstatningen fastsattes til kr. 3.061 svarende til den anslåede afhjælpningspris. 
ringskvitteringen, at klageren ville blive afkrævet et gebyr, hvis der fandtes en fejl, som ikke var omfattet af garantien. Det allmänna reklamationsnämnden udtalte, at det var tilstrækkeligt, at det fremgik af indleveringskvitteringen, at klageren ville blive afkrævet et gebyr, hvis der fandtes en fejl, som ikke var omfattet af garantien. Klageren kunne derfor ikke forlange telefonen udleveret uden at betale gebyret.

101. Sag 2003-04-16; 2002-8596

Klageren havde købt en mobiltelefon for kr. 1.689 i februar 2001. Han fik tre års garanti. I december 2002 indleverede han telefonen til forhandleren, idet knapperne og mikrofonen ikke virkede tilfredsstillende. Forhandleren oplyste, at telefonen led af en fugtskade, og at den derfor ikke kunne repareres. Klageren blev derudover afkrævet et undersøgelsesgebyr på kr. 395. Klageren ville have telefonen tilbage uden at betale gebyr. Forhandleren henviste til, at det fremgik af indleveringskvitteringen, at klageren ville blive afkrævet et gebyr, hvis der fandtes en fejl, som ikke var omfattet af garantien. Det allmänna reklamationsnämnden udtalte, at det var tilstrækkeligt, at det fremgik af indleveringskvitteringen, at klageren ville blive afkrævet et gebyr, hvis der fandtes en fejl, som ikke var omfattet af garantien. Klageren kunne derfor ikke forlange telefonen udleveret uden at betale gebyret.

Sag 2004-01-30; 2003-5753

Klageren havde købt et kamera. I forbindelse med at klageren indleverede kameraet til undersøgelse, blev han afkrævet kr. 275 i undersøgelsesgebyr. Udover at kræve ophævelse af købet, alternativt afhjælpning eller omlevering, krævede klageren de kr. 275 refunderet. Forhandleren afviste, at klageren havde misligholdelsesbeføjelser, men ville acceptere det hvis nævnet fandt, at der ikke skulle betales undersøgelsesgebyr. Det allmänna reklamationsnämnden udtalte, at da forhandleren ikke efter det oplyste havde orienteret klageren om, at han ville blive afkrævet et undersøgelsesgebyr, skulle gebyret refunderes. Nævnet afviste, at klageren havde misligholdelsesbeføjelser. Der gives ingen oplysninger om indholdet af et evt. indleveringsbevis.

103.

$$
\text { Sag 2002-01-08; 2001-4712 }
$$

Klageren havde købt en mobiltelefon for kr. 2.396. Han fik et års garanti. I garantiperioden ophørte telefonen med at fungere, og klageren indleverede derfor telefonen til reparation. Forhandleren oplyste efter endt undersøgelse, at det ikke var muligt at reparere telefonen, da den led af en fugtskade, og at klageren skulle betale kr. 175 for at få den tilbage. Det allmänna reklamationsnämnden udtalte, at telefonen efter det oplyste ikke led af en mangel. For så vidt angik undersøgelsesgebyret havde forhandleren ikke i forbindelse med købet af telefonen eller ved telefonens indlevering til undersøgelse, at klageren ville blive afkrævet et gebyr. Forhandleren kunne derfor ikke afkræve klageren kr. 175 som betingelse for udlevering af telefonen.

104.

Sag 2003-06-05; 2003-0220

Klageren havde købt en mobiltelefon til kr. 3.310. Hun fik et års garanti. Det viste sig imidlertid, at telefonen ikke kunne oplades, og klageren indleverede derfor telefonen til forhandleren to dage efter købet. Forhandleren udskiftede batteriet, 
hvilket medførte, at telefonen nu virkede, men fortsat ikke tilfredsstillende. Ringesignalet og vibratorfunktionen virkede kun delvist. I den følgende periode udviste telefonen flere funktionssvigt, og klageren endte derfor med at indlevere telefonen til forhandleren, som sendte den til leverandøren med henblik på garantireparation. Ca. en måned efter fik klageren besked om, at telefonen var fugtskadet, og at garantien derfor ikke gjaldt. Da hun bad om at få telefonen tilbage uden reparation, fik hun at vide, at hun i så fald måtte betale kr. 370 i undersøgelsesgebyr. Det allmänna reklamationsnämnden udtalte, at fejlen var opstået inden for garantiperioden, og reglen i konsumentköplagens § 21 derfor var relevant. Sælgeren var derfor fri for ansvar, hvis han kunne sandsynliggøre, at fejlen skyldtes „en plyckshändelse eller därmed jämförlig händelse eller vanvård, onormalt brukande eller liknande förhållande på köparens sida“. Under henvisning til den vedlagte brugsanvisning fandt nævnet, at sælgeren havde løftet sin bevisbyrde og dermed ikke var ansvarlig for fejlfunktionen. For så vidt angik undersøgelsesgebyret udtalte nævnet i forlængelse heraf, at det ikke fremgik af sagens oplysninger, om klageren var blevet orienteret om, at der skulle betales et undersøgelsesgebyr. Var det ikke tilfældet, havde klageren ret til at få telefonen udleveret uden at betale gebyret.

105.

Sag 2004-04-05; 2004-0032

Klageren havde købt en mobiltelefon til kr. 2.100. Hun fik et års garanti. Ca. 7 måneder efter købet indleverede klageren telefonen til forhandleren, idet der var en fejl i mikrofonen. Ifølge forhandleren var telefonen fugtskadet. Klageren måtte betale kr. 375 for at få telefonen udleveret uden reparation. Forhandleren oplyste, at klageren var blevet orienteret om hvilke omkostninger, klageren ville blive afkrævet, hvis der ikke fandtes en fejl, som var omfattet af garantien. Det allmänna reklamationsnämnden udtalte, at telefonen efter det oplyste ikke led af en mangel. For så vidt angik undersøgelsesgebyret udtalte nævnet, at det fremgik af indleveringskvitteringen, at klageren vil blive afkrævet et gebyr for foretaget undersøgelse og returfragt, hvis reparationen afbestilles. Gebyret skulle derfor ikke refunderes.

106.

Sag 2004-12-22, 2004-5311

En forbruger, A, havde købt en mobiltelefon med et års garanti. Knapt et år efter købet indleverede A mobiltelefonen til sælgeren, B, fordi nogle af knapperne var ophørt med at fungere. Hun fik efter det oplyste ingen information om hvilke vilkår, som gjaldt for garantireparation, herunder at hun kunne risikere at blive afkrævet et undersøgelsesgebyr. A ville derfor have mobiltelefonen retur uden at betale for undersøgelsen, hvilket B nægtede. B henviste i den forbindelse til, at det fremgik af indleveringskvitteringen, at der ville blive opkrævet et undersøgelsesgebyr, hvis undersøgelsen viste, at mobiltelefonen havde været udsat for ydre påvirkning i form af fugt mv. Det allmänna reklamationsnämnden fastslog, at det ikke fremgik, at A var blevet mundtligt orienteret om forpligtelsen til at betale et undersøgelsesgebyr, hvis B ikke var ansvarlig for en fejl ved mobiltelefonen. Nævnet udtalte herefter: „Frågan är om en information som endast lämnats skriftligen på ett inlämningsbevis kan anses vara tillräckligt klargörande för att en undersökningsavgift skall kunna tas ut.“ Nævnet nåede til, at det ikke var tilstrækkeligt, at vilkåret fremgik af indleveringsbeviset, når dette blev udleveret samtidig med, at varen blev indleveret til undersøgelse. Der var i så fald tale om et ensidigt fastsat aftalevilkår, som A ikke var bundet af. Nævnet tilføjede: „Det sagde innebär emellartid inte att en uuplysning om undersöknngsavgift på ett inläm- 
ningskvitto skulle sakna värde. Tvärtom kan en sådan skriftlig upplysning ha bevisvärde för att information har lämnats.“ I det konkrete tilfælde var det ikke gjort gældende, at forbrugeren havde fået informationen inden indleveringen af varen, hvorfor A havde ret til at få udleveret mobiltelefonen uden at betale et undersøgelsesgebyr. 